\title{
Article
}

\section{Plea Bargaining's Triumph}

\author{
George Fisher ${ }^{\dagger}$
}

\section{CONTENTS}

I. LIQUOR LAWS, MURder CASES, AND THE ProseCUTOR'S

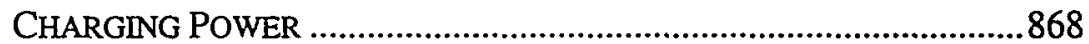

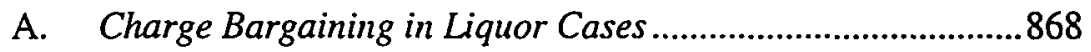

B. Charge Bargaining in Murder Cases.....................................85

II. THE PROSECUTOR'S MOTIVES IN PLEA BARGaINING .........................893

A. Why Plea Bargain at All? The Role of Caseload Pressure.....893

B. Why Plea Bargain in Liquor Cases?........................................904

C. Competing Theories ............................................................916

1. The Role of Absent Victims and Savvy Defendants........916

2. A Cultural and Political Approach .................................919

III. ON-FILE Plea Bargaining AND the Rise of Probation ..............936

A. The Prosecutor's Powers and On-File Plea Bargaining .........943

1. The Power To Protect Defendants from Judicial

Severity..........................................................................993

$\dagger$ Professor, Stanford Law School. Many people have helped me get hold of the records and documents that support this study. I would like to thank in particular Bill Milhomme. Michael Comeau, Janis Duffy, and the reference staff of the Massachusetts Archives; Mike Haire and John Reardon of the records management team at the Massachusetts Trial Court: Andrew Gurthet and Dave Bridgman of the Stanford Law School Library; and many and able rescarch assistantsBlake Hurst, Tami Swiger, Alexis Haller, Dan Levin, Josh Greenberg. and Tyler Fuller in Califomia, and Phil Coppinger in Boston.

For their guidance and insights, I would like to thank Al Alschuler, Dick Craswell. Ted Ferdinand, Lawrence Friedman, Tom Green, Tom Grey, Don Herzog, Adam Hirsch, Marc Miller, Chet Mirsky, Bill Simon, Avi Soifer, Mary Vogel, Lloyd Weinreb, and Bob Weisberg. Craig Estes gave me indispensable help managing the case database. And Mariza Okata, James Sing, David Lam, and the staff of The Yale Law Joumal have edited with insight and precision. 
2. The Prosecutor's Power To Protect Himself from Judicial Leniency.

B. Probation's Base-Born Status.

IV. THE DEFENDANT'S POWER TO PLEAD ……...................................965
A. The Power of Representation

B. The Impact of Defendant-Testimony Laws.

V. JUDGES AND THE POWER TO SENTENCE 984

A. Incentives: The Judges' Caseload Pressure ...........................989

B. Principles: The Effects of Probation and Parole ...................1001

C. Pride: The Plea-Withdrawal Rule ........................................... 1007

VI. EXPLAINING PleA BARgAINING's PROGRESS ElSEWHERE............1016

A. Plea Bargaining's Absence in Earlier Times........................1017

B. Plea Bargaining's Rise Elsewhere in America ......................1024

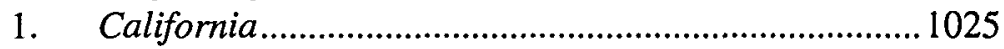

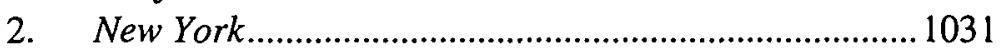

VII. THE POWER OF PLEA BARGAINING ................................................1038

A. The Sources of Plea Bargaining's Power .............................1038

B. The Consequences of Plea Bargaining's Power .....................1044

1. The Indeterminate Sentence........................................... 1044

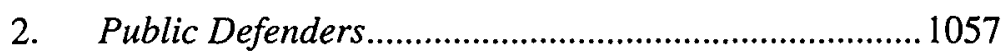

C. Principles of Procedural Change ..........................................1063

VIII. THe Balance OF Power To Plea Bargain ................................1067

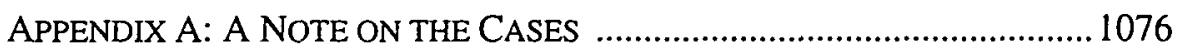

A. The Records and Where To Find Them ................................1076

B. Counting Cases and Statistical Protocols..............................1080

APPENDIX B: FERDINAND'S CATEGORY OF "VICE OR REGULATORY

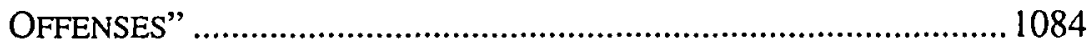


There is no glory in plea bargaining. In place of a noble clash for truth, plea bargaining gives us a skulking truce. Opposing lawyers shrink from battle, and the jury's empty box signals the system's disappointment. But though its victory merits no fanfare, plea bargaining has triumphed. Bloodlessly and clandestinely, it has swept across the penal landscape and driven our vanquished jury into small pockets of resistance. Plea bargaining may be, as some chroniclers claim, the invading barbarian. But it has won all the same.

The battle has been lost for some time. It was lost at least by the time prominent observers of the 1920s first lamented our "vanishing jury," and in some places it was lost decades before then. In the years since the jury succumbed in a war few knew it was waging, advancing waves of who-lostthe-jury scholarship have tried to retrace the path of defeat. Much of this work has charged that the ever-weightier burden of modern jury trials overbore the system, which surrendered to the plea bargain's efficiency to avert collapse. Another, newer collection of studies looks beyond the courtroom to spy out broader social forces that aided plea bargaining's cause. But in the breadth of its scope, this work overlooks the first principle of conflict: that victory goes to the powerful. And so while we can find many worthy accounts of why the jury fell, we must ask as well why plea bargaining triumphed.

Like most of history's victors, plea bargaining won in great part because it served the interests of the powerful. In the battlefield of the criminal courts, the kind of power that mattered most was the authority to dictate sentences, which judges held in great measure and prosecutors in a compromised but still substantial way. To track the course of plea bargaining's rise, we must discover how prosecutors, who had an almost inherent interest in plea bargaining, secured the power to make it happen, and why judges, who inherently had the power to make it happen, began to see it as in their interest. In this account of plea bargaining's rise, legisiators will play a large role, for their power to allocate sentencing authority between prosecutor and judge tilted the terms of battle. And criminal defendants, who held a nominally absolute power to plead or not to plead but who often found themselves hopelessly undefended, must play a real if complicated part.

This is not, then, a "social history" of plea bargaining's rise, if by that we mean a story that highlights the play of social forces and minimizes the role of human actors. Although recent scholars have put forth appealing accounts of the electoral pressure of new immigrants or the analogical force of new industry in the creation of "assembly-line justice," these theories either stand without evidence or fall beside the point. Plea bargaining's triumph was manifestly the work of those courtroom actors who stood to gain from it. To the extent that external actors, especially legislators, played 
a conscious role in the struggle, they mainly took sides with the ultimately defeated jury trial. And to the extent that broader social forces, such as immigration and industrialization, influenced the outcome of the conflict, they did so by increasing the criminal caseload on the one hand and the civil caseload on the other, thereby altering the interests and options of prosecutors and judges.

And yet in one striking way, the story of plea bargaining's rise is bigger than the actors who made it happen. Plea bargaining, once it took hold, possessed a power of its own. That power derived ultimately from the individual power of those whose interests plea bargaining served, but in its collective form that power made plea bargaining a dominant force in the evolution of modern American criminal procedure. Sometimes, plea bargaining's influence appears on the face of the historical record. This is most true in the case of probation, one of the most enduring nineteenthcentury contributions to our penal mechanisms. I will argue that the birth of probation was in some part, and perhaps in large part, the work of prosecutors who sought a new way to expand their power to bargain for pleas. Once in place, probation grew in symbiosis with plea bargaining and became in time one of the most useful tools of lawyers cutting deals.

Plea bargaining's role in shaping other procedural institutions appears more subtly in the historical record. But the unmistakable correlation between those procedural changes that have survived and thrived and those that aided plea bargaining's cause compels a conclusion that plea bargaining has so fast a grip on our institutions of justice that antagonistic institutions cannot survive. The demise of the indeterminate sentence, one of the most promising of the late nineteenth century's progressive brainchildren, bears the mark of plea bargaining's malice. A true indeterminate sentence, in which only prison officials and parole boards could set the length of criminal sentences, would have stripped both judges and prosecutors of the power to bargain over the length of terms and would have hobbled the plea-bargaining regime. But though widely promoted, true indeterminate sentences never emerged, and even the half-measure that we have come to know as parole found its development stunted when it threatened plea bargaining's dominance.

Probation's rise and the indeterminate sentence's fall are but two of plea bargaining's victories. Before canvassing the rest, we need to follow the course of plea bargaining's ascent to learn the source of its strength. 1 will tell this story as it unfolded in America, for although the earliest instances of plea bargaining may well have happened elsewhere,' and

1. J.S. Cockburn discovered what is perhaps the earliest clear evidence of plea bargaining anywhere. He found that between 1587 and 1590 , as many as half of the defendants who came before the assize courts of the English Home Circuit pled guilty. See J.S. Cockburn, Trial by the Book? Fact and Theory in the Criminal Process, 1558-1625, in LEGAL RECORDS AND TII: 
although plea bargaining in time would spread across the common-law world and beyond, it triumphed here first. Within America, I will focus on Massachusetts. Massachusetts is the birthplace of probation, and though I had little suspicion when I set out that plea bargaining and probation would prove so closely linked, it seemed likely that innovations would find a common home. Moreover, Massachusetts was among those states that acted most vigorously in the nineteenth century to suppress the sale of alcohol, and there was reason to suspect that enforcement of liquor laws played a part in plea bargaining's early rise. ${ }^{2}$

Within Massachusetts, I will focus mainly on its largest countyMiddlesex ${ }^{3}$ - which spreads south and east from the New Hampshire border to Boston's western edge, taking in the pioneering mill town of Lowell, the hamlets of Lexington and Concord, and cosmopolitan Cambridge. Middlesex's diversity avoids the possible distortions of Boston's idiosyncrasies, which particularly disrupted that city's enforcement of the liquor laws. ${ }^{4}$ Moreover, Middlesex was the practicing ground of Asahel Huntington, perhaps the first prosecutor in history to be called up on charges of plea bargaining. And Middlesex is where I practiced as a prosecutor, an experience that left me familiar with the ways of its courts and perhaps more aware of the ways in which things have changed.

Within Middlesex County, I will look most closely at the middle tier of the county's judicial system, which had jurisdiction over all but the most serious crimes. A succession of courts occupied this middle tier during the nineteenth century-the Court of General Sessions of the Peace until 1804, the Court of Common Pleas from 1804 until 1859, and the Superior Court after $1859 .{ }^{5}$ At the four annual sittings of the Court of General Sessions of

HISTORIAN 60, 73 (J.H. Baker ed., 1978). These defendants seem to have eamed two kinds of rewards for their pleas, both of which Cockburn attributes to judicial action. First, judges apparently altered indictments to reduce the charges. Second, judges granted benefit of clergy-a mechanism for avoiding execution-more readily to those defendants who pled guilty. See id.

2. Although one of the first studies of the pattems of plea bargaining recognized the probable impact of the rush of cases brought on by national prohibition in the 1920s. see 1 AMERICAN LAW INST., A STUDY OF THE BUSINESS OF THE FEDERAL COURTS 31-32, 57 (1934), the first study I have seen to hint that state liquor laws of the 19 th century may have played a role in plea bargaining's rise is Alber Alschuler's 1979 work, see Albert W. Alschuler. Plea Bargaining and Its History, 79 COLUM. L. REV. 1, 6 (1979).

3. Though the ranking of the counties was unstable. Middlescx was the largest during every census from 1840 to 1870 . See A COMPENDIUM OF THE NINTH CENSUS 56 (Washington. D.C., Government Printing Office 1872).

4. Roger Lane has detailed the unwillingness of Boston police to enforce the state's liquorprohibition laws in the third quaner of the 19th century. See ROGER LANE, POLICING THE CrTY: BOSTON 1822-1885, at 87 (1967) ("It was soon obvious that [the liquor prohibition law of 1852] would not be enforced in Boston ....").

5. See Act of Apr. 5, 1859, ch. 196, §§ 1-3, 1859 Mass. Acts 339. 339-40 (establishing the superior courts); Act of Mar. 9, 1804, ch. 89. $\S \S 3-4,1804$ Mass. Acts 490, 491 (enlarging the jurisdiction of the courts of common pleas and transferring the criminal jurisdiction of the Court of General Sessions of the Peace to the Court of Common Pleas). Catherine Menand's suggestion that there were several shifts in criminal jurisdiction between 1803 and 1827 results, I think. from 
the Peace, local justices of the peace presided jointly over jury trials. ${ }^{6}$ At both the Court of Common Pleas and the Superior Court, jury trials took place before professional judges who rode circuit throughout the state, sitting in each county three or four times a year and ensuring some statewide uniformity of practice. ${ }^{7}$ These middle-tier courts promise to be better sites for this study than the courts of the lower tier. The bottom tier of the state's judiciary ${ }^{8}$ lacked two institutions-jury and prosecutor-whose role in the criminal system looms far too large for us to think that much can be explained without them.

My examination of the upper tier, occupied by the Supreme Judicial Court, will not range as far because the criminal trial jurisdiction of that court was quite narrow and grew narrower as the nineteenth century wore on. Like judges of the middle tier, justices of the high court rode circuit across the state to preside over criminal jury trials. ${ }^{9}$ At the century's start, their jurisdiction included an array of serious crimes, but soon shrank to include only capital crimes, a category that, in turn, dwindled by midcentury to include only murder. In 1891, the Supreme Judicial Court lost even murder trials to the courts of the middle tier. ${ }^{10}$

a misreading of the relevant statutes. See CATHERINE S. MENAND, A RESEARCH GuIDE to THE MASSACHUSETTS COURTS AND THEIR RECORDS 50 (1987). In any case, my examination of the records of the Court of Common Pleas and the Court of General Sessions of the Peace for Middlesex County revealed no shift in criminal jurisdiction after 1804 .

6. See Act of July 3, 1782, ch. 15, 1782 Mass. Acts 157, 157 (establishing courts of general sessions of the peace).

7. See $\S 10,1859$ Mass. Acts at 342 (establishing the dates and locations of roving civil and criminal courts in Middlesex County); Act of Feb. 14, 1821, ch. 79, $\S 2,8$ Mass. Laws 545, 546 (establishing a Court of Common Pleas for the Commonwealth of Massachusetts). Before 1821. the Court of Common Pleas consisted of separate judges for each county or for small groups of counties, rather than a corps of judges who rode circuit. See WILLIAM T. DAVIS, HISTORY OF THE JUDICIARY OF MASSACHUSETTS 201-04 (1900). At various times, Boston (that is, Suffolk County) had criminal tribunals distinct from this statewide system. See id. at 205-06.

8. In the early years treated in this study, individual justices of the peace presided alone over trials of the more petty criminal offenses. Their judgments could be appealed to a jury trial before the courts of the middle tier. See MENAND, supra note 5, at 60 . In time, a system of police courts and finally district courts would succeed to the jurisdiction of the individual justices, but these courts continued to sit without a jury and without even the regular attendance of a public prosecutor. See id. at 61-67.

9. See id. at 37-38.

10. See Act of June 6, 1891 , ch. 379, $\S 1,1891$ Mass. Acts 966,966 (transferring jurisdiction of capital trials to the superior courts); Act of Oct. 17, 1859, ch. 282, $\S 1,1859$ Mass. Acts 632. 632 (returning jurisdiction of capital trials to the Supreme Judicial Court); $\$ \S 1,21,1859$ Mass. Acts at 339,344 (establishing the superior courts and briefly transferring jurisdiction of capital trials from the Supreme Judicial Court to the superior courts); Act of Mar. 14, 1832, ch. 130, 12 Mass. Laws 396 (enlarging the jurisdiction of the Court of Common Pleas in criminal cases. regulating the appointment and duties of prosecuting officers, and transferring the Supreme Judicial Court's criminal trial jurisdiction, except in capital cases, to the Court of Common Pleas); Michael STEPHEN Hindus, PRISON AND Plantation: CRIME, JUSTICE, AND AUTHORITY in MASSACHUSETTS AND SOUTH CAROLINA, 1767-1878, at 93 (1980) (noting that by 1852, murder was the only offense that remained capital in Massachusetts); infra note 95. 
Rarely handling more than a handful of criminal trials a year, the Supreme Judicial Court would not serve well as a focus for a study of plea bargaining's rise. Still, it is important to include its business in this study, both to assure that the practices I observed in the middle tier were not somehow peculiar to less serious criminal cases and to take advantage of the sometimes superior records of Supreme Judicial Court business and of the deeper insights they afford. As we will see, the rise of plea bargaining before the Supreme Judicial Court tracked roughly the same course as in the courts of the middle tier. Though it began perhaps a little later, plea bargaining in capital cases soon caught up with and at times overtook the development of plea bargaining in the courts below. More importantly, we will see in both tiers the same dynamic at work: The powers and interests of individual courtroom actors appear to explain the course of plea bargaining's rise.

The records of the middle-tier courts for the years before 1859 have survived in almost full form, and those for the years since have suffered only minor losses and deletions. I have found no important gap in the records of the Supreme Judicial Court." Complete as they may be, these records are hardly expressive of what went on in the courts of nineteenthcentury Massachusetts and are maddeningly silent about the motivations behind most guilty pleas. The clerk's vacant formulas usually erased the tracks of any express agreement by prosecutor or judge to grant the defendant a concession in exchange for a plea. In most cases, therefore, we must use other methods to distinguish those defendants who pled guilty out of remorse for their crimes or to shorten their engagements in court from those who did so as part of a plea bargain, expecting to win some concession in exchange. We must employ still other devices to distinguish explicit plea bargains, in which the parties spoke out loud the terms of their exchange, from implicit bargains, in which the defendant pled guilty for an unpromised but hoped-for reward. My sampling of some 4000 cases $^{12}$ often permits statistical conclusions about the frequency and nature of plea bargaining even when individual case reports are mute. And newspapers and other contemporary sources help decipher the clerk's cryptic codes. These sources also make plain that the lessons of Middlesex County apply generally throughout Massachusetts and, with allowances for statutory and regional variances, in several other jurisdictions as well.

11. As I will explain below, I did not always rely directly on the Supreme Judicial Cour's own records, but often referred instead to the state attomey general's annual summaries of his business before that court. See infra notes 92, 97, 99 and accompanying text. The Supreme Judicial Court's reconds did prove important in filling gaps when the attomey general's reports were missing or ambiguous.

12. My data set includes 4142 cases heard in the middle-tier courts of Middlesex County between 1789 and 1910, as well as several hundred cases from the Supreme Judicial Cour and the courts of Essex County. I have described the data set in more detail in Appendix A. 
This story of plea bargaining's rise begins in the opening decade of the nineteenth century. One could begin earlier, as there is solid evidence of plea bargaining in earlier centuries, but that evidence is of isolated, episodic plea bargaining, whereas this is the story of plea bargaining's triumph as a systemic regime. Told chronologically, the story divides fairly neatly into two parts. During the first three-quarters or so of the nineteenth century, plea bargaining in Massachusetts advanced mainly in the realm of liquorlaw prosecutions and murder cases, where for reasons we will explore, prosecutors had the power to negotiate pleas without any participation by the judge. These early deals took the form of charge bargaining - that is, in exchange for the defendant's plea to one or more of several charges, the prosecutor dropped the others or (in the case of murder) reduced the charge to a lesser offense. In the last quarter of the century, as judges converted to the cause, plea bargaining most often took the form of sentence bargaining, in which the defendant's plea won a reduced sentence. Backed by judges as well as prosecutors, plea bargaining now broke the narrow hold of liquor and murder prosecutions and conquered the whole penal territory-so that by century's close, guilty pleas accounted for some eighty-seven percent of criminal adjudications in Middlesex County. ${ }^{13}$

As useful as this simple chronology may be, I at times will stray from the rather clean story line it provides. My aim is to highlight how the changing powers and interests of each courtroom actor played dominant roles in shaping the course of change. These two ways of telling the story are not always at odds: I will begin with the role of prosecutors, whose influence emerged most clearly in the liquor-law prosecutions of the century's first half, and I will conclude with judges, whose changing behavior in the last quarter of the century assured plea bargaining's triumph. At times, though, the focus on individual actors will require us to leap ahead or to fall back.

So I will begin with prosecutors. That prosecutors take up three parts of this eight-part study is not because their power to bargain was greatest of all. In fact, the judge held the largest share of the power to dictate sentences and therefore to plea bargain, while the prosecutor's power was almost always subordinate to his. I linger on the prosecutor's role precisely because the prosecutor managed to elude the judge's control only rarelyand then only by virtue of extraordinary legislative grant or procedural ingenuity. Part I will address the first of these extraordinary legislative grants, made in the context of liquor-law prosecutions and, with some differences, in capital cases. My research in Middlesex County confirms earlier findings of a strikingly high rate of plea bargaining in Massachusetts liquor-law prosecutions in the early nineteenth century. Various good

13. See infra note 499. 
theories might explain a link between liquor prosecutions and plea bargaining, but the evidence overwhelmingly points to one-that the distinctive penalty scheme that the legislature created for the liquor laws, which assigned a fixed fine to almost every offense, deprived the judge of almost all sentencing discretion and put the prosecutor in a position to manipulate sentences by manipulating charges. Similarly, in capital cases, the prosecutor had the power to spare defendants mandatory death by permitting them to plead guilty to a lesser charge. Prosecutors quickly exploited these narrow grants of sentencing authority and put in place a very modern practice of charge bargaining for pleas.

Explaining the source of prosecutorial power to plea bargain is the hard part-it is easy to see why prosecutors wanted to plea bargain. Prosecutors of the nineteenth century, like prosecutors today, plea bargained to ease their crushing workloads, made heavier in the nineteenth century both by their part-time status and utter lack of staff and by a caseload explosion perhaps set off by newly founded police forces and massive immigration. And of course they plea bargained to avoid the risk that wanton juries would spurn their painstakingly assembled cases. Given such clear incentives, the task of explaining the rise of prosecutorial plea bargaining in liquor and capital cases should have been complete at the end of Part I-for as soon as prosecutors had the power to plea bargain, they surely would have used it. Still, I will need to consider in Part II the arguments of those scholars of plea bargaining who have dismissed the importance of caseload pressure in explaining the rise of plea bargaining and have put forward other explanations for the early emergence of plea bargaining. And I will need to consider why judges were not partners in this early rise of plea bargaining. For if they had been, plea bargaining would not have been limited to liquor and murder cases-in which prosecutors had the power to plea bargain on their own-but could have extended across the criminal docket.

In Part III, I will step briefly out of the courthouse and into the State House. Massachusetts legislators reacted sourly when they discovered how prosecutors were using the power unwittingly bestowed on them by the liquor law's rigid penalty scheme. At mid-century the legislature eliminated this power and very nearly succeeded in snuffing out prosecutorial plea bargaining in liquor cases. The legislature did not, however, disturb the prosecutor's power to conduct charge bargaining in murder cases, for there had been relatively few such bargains by mid-century. The result was that during the third quarter of the nineteenth century, plea bargaining advanced more dramatically in murder cases than in any other category. Even in liquor cases, the legislature's efforts to eradicate prosecutorial charge bargaining failed. After losing formal power to manipulate sentences in liquor cases, prosecutors retreated to the more covert and informal tactic of 
placing these cases "on file." This procedural maneuver, often done in exchange for a defendant's guilty plea, allowed prosecutors to elude altogether the legislature's sentencing provisions. The primitive device of on-file plea bargaining evolved directly into what we know today as probation. By the end of the century, probation had become one of plea bargaining's most dependable foot soldiers.

Turning from the prosecutor's role in early plea bargaining to that of other actors, I will move on in Part IV to consider the part played by defendants. It is not hard to see why defendants, given the chance, would plead guilty for a measure of leniency, but it is far less clear why their behavior on this score might change over time. Middlesex court records disclose that during the first half of the nineteenth century, decades before plea bargaining began its dramatic ascent, there had been a long decline in the proportion of non-liquor cases that ended in a plea. I will argue that these early guilty pleas were not plea bargains made in exchange for leniency, but rather the hopeless gestures of unrepresented defendants who properly saw that they had little chance of winning if they went to trial on their own. The gradual increase in the number of defendants who chose trial during the first part of the century therefore may mean that more and more defendants had counsel. Then, in the third quarter of the century, a sudden assault on the power of defendants to take their cases to trial may have reversed this course and helped to speed plea bargaining's rise. Laws passed in Massachusetts and elsewhere that gave defendants the right to testify at trial had the probably unintended effect of discouraging defendants with criminal pasts from going to trial. Seasoned criminals knew that if they took the stand to claim their innocence, the prosecutor could impeach their testimony with their old convictions and thereby destroy any real chance of acquittal. Yet if they failed to testify, defendants believed, juries would convict them for their silence. Together with the growing practice of probation, defendant-testimony laws confronted every defendant with a good reason to plea bargain. Defendant-testimony laws helped to persuade accomplished criminals to plead guilty, while the promise of probation, which was available almost exclusively to first offenders who pled guilty, served as an incentive for everyone else.

The combined willingness of all prosecutors and many defendants to bargain for pleas was not, however, enough for the practice to thrive outside the narrow context of liquor laws and murder cases. The statutory penalty structure for most crimes gave Massachusetts judges such great discretion in sentencing that the prosecutor typically could not unilaterally guarantee a low enough sentence to win the defendant's plea. Plea bargaining's sweeping triumph during the last quarter of the nineteenth century suggests, therefore, that judges had entered plea bargaining's ranks. I will argue in Part V that a caseload explosion on the civil side of Massachusetts 
courthouses helped force this change of judicial heart on the criminal side, for in Massachusetts, as in most American jurisdictions, the same judges sat on both civil and criminal cases. The industrial boom of the last part of the nineteenth century - and especially the spread of railroads and street carsspawned a whole new strain of personal injury litigation that, case for case, absorbed far more time than the contractual nonpayment cases that once had filled the civil dockets. The figures in Massachusetts are clear: As judges devoted a hugely increasing proportion of their time to the civil caseload, they devoted a shrinking proportion to the criminal caseload, and they resolved more and more criminal cases by guilty plea. Judges apparently discovered that they had more power to spur pleas in criminal cases than to coerce settlements in civil cases. After all, a criminal court judge could credibly promise a reward in exchange for a plea or threaten a penalty for going to trial, but in civil court, the jury-not the judgegenerally set the loser's penalty.

By century's end, all three of the courtroom's major actorsprosecutor, defendant, and judge-had found reasons to favor the pleabargaining system. For prosecutor and judge, who together held most of the power that mattered, the spread of plea bargaining did not merely deliver marvelously efficient relief from a suffocating workload. It also spared the prosecutor the risk of loss and the judge the risk of reversal, and thereby protected the professional reputations of each. In fact, by erasing the possibility of either factual or legal error in the proceedings, plea bargains protected the reputation and hence the legitimacy of the system as a whole. In Part VI, I will ask whether these variables of power and interest, which emerge from the records of Middlesex County and of the Supreme Judicial Court, can help explain the course of plea bargaining's rise in other jurisdictions. In England, New York, and California, the evidence suggests that they can.

I will move on in Part VII to explore the power that plea bargaining as an institution has amassed by serving the interests of power so well. The power of the various actors who stood to gain from plea bargaining became, in a sense, plea bargaining's power. This collective, systemic interest in plea bargaining encouraged the rise of those institutions of criminal procedure that helped plea bargaining and hindered those that hurt it. In the nineteenth century, plea bargaining fostered probation's rise and thereby created a hugely versatile plea-bargaining tool. In the late nineteenth and early twentieth centuries, plea bargaining helped stave off the indeterminate sentence, which had threatened to halt plea bargaining's progress. And in the twentieth century, plea bargaining played a surprisingly direct role in assisting the creation of public defenders. In turn, these organizations for defense of the poor assured that in a majority of criminal cases, the defense lawyer would share the prosecutor's and judge's interests in maximizing 
systemic efficiency - and hence in plea bargaining. These examples of plea bargaining's influence over other institutions of criminal procedure are merely case studies within a larger trend. In fact, it is hard to think of a single enduring development in criminal procedure in the last 150 years that has not aided plea bargaining's cause.

Finally, in Part VIII, I will examine how the power to plea bargain evolved in the late twentieth century. Before the advent of modern sentencing guidelines, both prosecutor and judge held some power to plea bargain without the other's cooperation. The result of their mutually independent bargaining strength was a certain balance of power, which to some degree protected defendants from abuses of power by either official. Today, however, sentencing guidelines have recast whole chunks of the criminal code in the mold of the old Massachusetts liquor laws. In the process, they have unsettled the balance of bargaining power by ensuring that the prosecutor, who always had the strongest interest in plea bargaining, now has the unilateral power to deal.

And so in time we will arrive again at the Massachusetts liquor laws, where we now begin.

\section{LIQUOR LAWS, MURDER CASES, AND THE PROSECUTOR'S CHARGING POWER}

\section{A. Charge Bargaining in Liquor Cases}

In 1807, Samuel Dana took office as the first Middlesex County attorney. ${ }^{14}$ His main forum was the Court of Common Pleas, which occupied the middle tier of the Massachusetts criminal judicial enterprise. Dana did not launch his young office with honor. By 1809, he was before the legislature explaining why he had complained to three of the court's judges about their "unbecoming impetuosity, and snarling manner." ${ }^{15} \mathrm{He}$

14. Dana (1767-1835) was appointed by Massachusetts Governor James Sullivan. See 2 WILLIAM T. DAVIS, BENCH AND BAR OF THE COMMONWEALTH OF MASSACHUSETTS 33 (Boston. Boston History Co. 1895). The legislature had created the office of county attomey earlier that year, probably to relieve the attorney general and solicitor general of the burden of managing public prosecutions statewide. See Act of June 20, 1807, ch. 18, \$1, 1807 Mass. Acts 172, 172 (delineating the offices and duties of the attorney general, solicitor general, and county attorncys). Dana had held the role of prosecutor provisionally since 1804. In that year, the Court of Common Pleas appointed him to prosecute cases for the Commonwealth "until further notice of this Court." Middlesex Ct. C.P. R. Book 338 (Sept. 1804). Dana was a lawyer in Groton beforc his appointment as county attorney. Later he sat as a judge on the Circuit Court of Common Pleas, served as president of the Massachusetts Senate, and held a brief tenure as Congressman. See James Dana, Memoir of THE Late Hon. Samuel Dana 5-7, 10-13 (Cambridge, John Wilson \& Son 1877); 2 DAVIS, supra, at 33.

15. MASSACHUSETtS HOUSE OF REPRESENTATIVES, REPORT OF THE COMMITTEE APPOINTED ON THE MEMORIAL OF SAMSON WOODS, COMPLAINING OF CERTAIN CONDUCT OF Samuel Dana, Esquire, in His Office of COUNTY ATtorney for the County of 
had to explain as well why he had billed the court for services to crime victims that seemed to fall within his official duties ${ }^{16}$ - and why he had represented a crime victim in a civil suit even as he prosecuted the case's criminal counterpart. ${ }^{17}$ Against these well-founded charges, Dana mounted a pathetic and lawyerly defense. ${ }^{18}$ By the end of 1809 , he apparently was out of office, and the same "snarling" judges had appointed another in his place. ${ }^{19}$ Dana won the last hand, though, for when the legislature

MIDDLESEX 10 (1809) [hereinafter REPORT OF THE DANA COMMrTtEe] (on file with the Massachusetts Historical Society). A legislative committec's repon alleged that Dana wrote his letter of complaint after the judges refused him a continuance. See id. at 7. Dana advised the judges, "I too often perceive an unbecoming impetuosity, and snarling manner, ill suited to the soft ermine of justice ...." Id. at 10 .

16. The legislature's investigating committee charged that when Dana helped crime victims seek reimbursement from the court for the costs of bringing charges, he listed his own five-dollar fee for providing this assistance as one such cost, but neglected to inform the court that the money was for him. Then, in his official role, he certified this table of costs to the court, which reimbursed the victim, who then paid Dana's fee. When alen judges asked the meaning of these five-dollar charges, Dana "observed that it was well known that [erime victims] were often obliged to get the professional assistance of lawyers," but he did not observe that he was the lawyer in question. Id. at 2-3.

The act creating the office of county attomey barred public prosecutors from receiving " any fee or reward from or in behalf of any prosecutor [i.e., crime victim], for services in any prosecution, to which it shall be his official duty to attend." \$2,1807 Mass. Acts at 171.

17. See REPORT OF THE DANA COMMTTTEE, supra note 15, al 6-7.

18. On the charge that he improperly billed the court for his assistance to crime victims in filling out reimbursement petitions, Dana argued that because the crime victim's "application for allowance is not part of the prosecution," his help in filling out the reimbursement forms, while "professional," was not "official," and it was therefore no violation of the statuce for him to bill for such services. Samuel Dana, Mr. Dana's Answer to the Repor of the Committee of the House of Representatives 2-3 (Feb. 28, 1808) (on file with the Massachusetts Historical Society). As for his reluctant response to the cour's inquiry about the significance of the five-dollar charges, he protested, "The question was not asked; nor was any inquiry or observation made, which sug[g]ested to me an idea that the cour considered it material to whom the sum was paid." Id. at 7.

To the charge that he handled the prosecution of a certain case even as he represented the crime victim in a related civil suit, Dana replied that it was not he, but his law parner. Richardson, who represented the victim-" not on the partership account. but on that of Mr. Richardson individually." Id. at 8-9. Finally, with regard to his querulous letter to the court. Dana wrote that "however incautiously it may be expressed ... it contained my real opinion as to the correctness of their proceeding in the case." Id. at 10-11. Except for the documents cited in this note and supra note 15, I have found no other source on this dispute and cannot report its outcome in the legislature.

19. Dana addressed his offending letter to the "Justices of the Cour of Common Pleas for the County of Middlesex, at December Term. 1808." REPORT OF THE DANA COMMITIEE, supra note 15, at 8. Court records show that the same judges who sat in December 1808 (James Prescott. James Winthrop, and Ephraim Wood) were also sitting in September 1809, when the Coun of Common Pleas appointed Asahel Stearns to be Middlesex County attorney. Stearns's appointment permits the strong inference that Dana was out. See Middlesex Ct. C.P. R. Book 289, 723 (Sept. 1809); Middlesex Ct. C.P. R. Book 339 (Dec. 1808). That Stearns appeared again in the following session of court strengthens the inference. See Middlesex C. C.P. R. Book 513 (Dec. 1809).

On the other hand, in his rather exhaustive history of the Massachusets cours. William Davis reported that Dana was reappointed as county attomey on September 3, 1811: that he was succeeded by one Timothy Fuller on November 20 of the same year, and that Steams did not take office until August 20,1813. See 2 DAVIS, supra note 14, at 33 . The confusion seems traceable to acts of the legislature. On June 20, 1809, the legislature repealed that par of the 1807 Act creating 
reorganized the Court of Common Pleas in 1811, those judges lost their seats, and Dana was named the new court's chief. ${ }^{20}$

For our purposes, Dana's most important legacy lies not in his spat with the judges, but in another aspect of the December 1808 sitting of the Court of Common Pleas-the term of court that gave rise to the controversies just noted. ${ }^{21}$ We find in the records of that term the case of Josiah Stevens of Tyngsborough, who faced prosecution under the state's 1787 liquor-license law requiring that alcohol retailers be licensed. ${ }^{22}$ The Stevens prosecution was one of Dana's first liquor cases and only the third liquor case to come before the Court of Common Pleas in Middlesex County after that court had begun to hear criminal matters in $1804 .{ }^{23}$ Dana had drawn up a four-count indictment against Stevens: Count one charged him with being a "common seller" of alcohol, counts two and three with making particular unlicensed sales, and count four with selling alcohol and permitting the buyer to drink on Stevens's premises. The court's clerk narrated the outcome:

the office of county attorney that provided for the means of appointment. See Act of June 20, 1809 , ch. 31, 1809 Mass. Acts 37, 37 (repealing the first section of the act respecting the offices and duties of the attorney general, solicitor general, and county attorneys). In so doing, the legislature presumably transferred power to appoint county attomeys from the governor to the court. It then reversed course in 1811 and restored the 1807 Act, returning the appointment power to the governor. See Act of June 18, 1811, ch. 10, § 1, 1811 Mass. Acts 279, 279 (delineating the offices and duties of the attomey general, solicitor general, and county attorneys).

20. See Act of June 21, 1811, ch. 33, § 2, 1811 Mass. Acts 424, 424-25 (establishing circuit courts of common pleas); DAVIS, supra note 7, at 202-04. The court's records show that at the first three sittings of 1811 , Judges Prescott, Winthrop, and Wood still presided. At the December sitting, Dana presided as chief together with Judges William Wetmore and Stephen Minot. See Middlesex Ct. C.P. R. Book 249 (Dec. 1811); Middlesex Ct. C.P. R. Book 1 (Sept. 1811): Middlesex Ct. C.P. R. Book 1 (June 1811); Middlesex Ct. C.P. R. Book 1 (Mar. 1811).

21. See REPORT OF THE DANA COMMITTE, supra note 15 , at 3, 6-8.

22. See Act of Feb. 28, 1787, ch. 68, 1786 Mass. Acts 206, 206; Commonwealth v. Josiah Stevens, Middlesex Ct. C.P. R. Book 803 (Dec. 1808).

23. Two earlier cases had come before the Court of Common Pleas. In September 1804, William Collins Hookway was tried before a jury and convicted and fined as a liquor dealer. See Commonwealth v. William Collins Hookway, Middlesex Ct. C.P. R. Book 333 (Sept. 1804). At about the same time--but apparently shortly afterward-the court appointed Dana to prosecute cases for the Commonwealth. See id. at 338. In 1805, Dana handled the case of Amos Brown, charged with keeping an unlicensed tavern. Dana nol prossed the complaint after Brown paid the costs of prosecution. See Commonwealth v. Amos Brown, Middlesex Ct. C.P. R. Book 191 (Mar. 1805). This exchange in some ways resembled a plea bargain, but it lacked a critical feature, as Brown never pled either guilty or no contest.

I studied the work of the court that preceded the Court of Common Pleas-the Court of General Sessions of the Peace-during 1789-1790 and 1799-1800. That court heard three liquor cases in these four years. The first, Commonwealth v. William Barker, took an interesting form that I will discuss in infra note 310 . The second and third both concerned the same defendant, Samuel Brown. Each case charged a single count of unlicensed sale. In each, Brown pled no contest and was fined and assessed costs. There is no indication in these two cases of any sort of concession granted to the defendant in exchange for his plea. See Commonwealth v. Samucl Brown, Middlesex Ct. Gen. Sess. Peace R. Book 532 (Sept. 1800); Commonwealth v. Sarnuel Brown, Middlesex Ct. Gen. Sess. Peace R. Book 532 (Sept. 1800). 
[T] he said Josiah [Stevens] says he will not contend with the Commonwealth. And Samuel Dana Esquire Atty. for the Commonwealth in this behalf says that in consequence of the defts. plea aforesaid he will not prosecute the first third and fourth counts against him any further. ${ }^{24}$

Dana and Stevens had struck a deal: In exchange for the defendant's plea of no contest, Dana dropped three of the four counts of the indictment. On the remaining count, Stevens paid a fine of $\$ 6.67$ and $\$ 47.12$ for the costs of prosecution. $^{25}$

Dana prosecuted only one additional liquor case during the rest of his brief tenure as county attorney. In March 1809, he brought a four-count indictment against Nathan Corey, a husbandman of Stow: Count one charged Corey with being a common seller of alcohol, and counts two, three, and four with making particular unlicensed sales. The clerk's account of the result varies from that in Stevens only in that Dana lived up to his part of the bargain first:

Samuel Dana Esquire Attorney for the Commonwealth in this behalf says that he will no further prosecute the said Nathan Corey upon the first second and fourth counts in said indictment and thereupon the said Nathan Corey by leave of Court says he will not contend with the Government as to the third count in said indictment. ${ }^{26}$

\section{Corey paid a fine of seven dollars together with $\$ 19.73$ in costs. ${ }^{27}$}

These are by no means the earliest guilty pleas I discovered in my search of the Middlesex court records. In fact, a surprisingly high percentage of cases in the earliest years of my study ended in pleas of guilty or no contest. In the Court of General Sessions of the Peace, which heard criminal cases before criminal jurisdiction passed to the Court of Common Pleas in $1804,{ }^{28}$ seventy-three percent of adjudicated cases in 1789-1790 ended in a plea, ${ }^{29}$ and sixty-six percent of those in $1799-1800 .^{30}$ In 1809 ,

24. Stevens, Middlesex Ct. C.P. R. Book at 804.

25. See id. The odd amount of the fine-\$6.67- an be traced to the statute, which set the penaity for an unlicensed sale at "a sum not exceeding six pounds, nor less than forty shillings [i.e., two pounds]." 1786 Mass. Acts at 207. In 1820, the records of the Court of Common Pleas noted that "the sum of five pounds [is] equal to sixteen dollars sixty six cents and six mills." Commonwealth v. Grosvenor Tarbell, Middlesex CL. C.P. R. Book 273 (Sept. 1820). At this conversion rate, two pounds would equal $\$ 6.67$.

26. Commonwealth v. Nathan Corey, Middlesex CL. C.P. R. Book 380 (Mar. 1809).

27. See id. It appears that the court by then had abandoned the cumbersome fine of $\$ 6.67$, see 1786 Mass. Acts at 207, and had chosen to round the figure up to seven dollars.

28. See Act of Mar. 9, 1804, ch. 154, $\S 3-4,1803$ Mass. Acts 788, 789 (enlarging the jurisdiction of the courts of common pleas).

29. Or 16 cases out of 22 . By "adjudicated" cases, I mean cases in which the defendant went to trial or pled guilty or no contest. 
when Nathan Corey stood before the Court of Common Pleas, fifty-eight percent of adjudicated cases ended by plea. ${ }^{31}$ These were not merely liquor cases, but included both felony and misdemeanor cases from across the broad jurisdiction of the middle-tier courts. But Stevens and Corey are two of only three cases in these years that appear on the face of the records as clear plea bargains. ${ }^{32}$ That is, these are the only cases in which the clerk's account discloses a concession made in exchange for the defendant's plea. Throughout this study, I will use the term "clear plea bargain" to refer to those cases in which the record makes it clear that the defendant won a concession by offering a plea. By contrast, I will use the expression "guilty plea" to refer to cases in which the defendant pled guilty but the record reveals no compensating concession. Sometimes we can look behind the silent record of a simple "plea" to discover the terms of a "bargain," but this is a matter we will take up in time.

Although Stevens and Corey are among the earliest clear plea bargains to emerge in my survey, they are of a remarkably sophisticated cut. We cannot know Dana's thoughts as he sought these four-count indictments, but today we would say that a prosecutor who brought several charges in the hope of gaining leverage in plea negotiations had "over-charged" the case. Dana may have had other motives for charging these cases as he did,,$^{3 .}$ but given the four-count indictments, he was in a position to threaten the defendants with multiple penalties and then to reward their pleas of no contest by dropping three of the four counts. Note that Stevens and Corey chose not to plead plainly "guilty" to the remaining count of the indictment. Rather, they would "not contend with the Commonwealth." and by means of these pleas of nolo contendere, they spared themselves any admission of fault while giving the court the power to convict and sentence

30. Or 21 cases out of 32 .

31. Or 7 cases out of 12 .

32. The third case followed the form but lacked the substance of the Stevens-Corey bargains. In 1790, George Peters faced several indictments for theft, including one that charged that he had stolen a pair of spectacles and a pair of scissors. To this indictment, he said that he was "guilty of taking the spectacles but not guilty of taking the scissors." Commonwealth v. George Pelers, Middlesex Ct. Gen. Sess. Peace R. Book 7 (Sept. 1790). A lawyer who acted temporarily for the government announced that he would "no further prosecute as to the scissors." Id. But unlike Stevens and Corey, Peters won little benefit from the government's "concession." The charge remained unchanged because subtraction of the scissors did not alter the grade of the theft. It altered only the measure of the restitution, set in the usual way at three times the value of the goods stolen, and now reduced by three times the value of the scissors. See id.

33. The statute did not define the offense of being a "common seller" as charged in count one, and I have not found elsewhere a definition that governed at this time. In an 1852 law that established liquor prohibition in Massachusetts, the legislature provided that "three several sales ... shall be sufficient to constitute" the offense of being a common seller. Act of May 22 . 1852 , ch. $322, \S 12,1852$ Mass. Acts 48,50 . Perhaps there is carlier case law, unknown to me. establishing such a definition. In that case, Dana's indictments would perhaps be redundant, but not designedly excessive. 
them. ${ }^{34}$ To winnow the excess charges, Dana employed the nolle prosequi, or nol pros, which the Supreme Judicial Court only recently had declared to be an exclusively prosecutorial device. ${ }^{35}$ Gadget for gadget-multiple-count indictments, nolo pleas, and nol prosses-these early plea bargains rival some of the best work of modern plea practitioners. And yet they emerged here, only a year into the tenure of the first county attorney, an almost instinctual urge of the prosecutorial soul.

Sophisticated as these pleas may have been, it is not immediately obvious why they worked. Why should Stevens and Corey have pled guilty, even to a single charge, if the presiding judges had the power to punish them severely for the one remaining violation? True, one's exposure is always greater having been convicted on four counts than on one, but many defendants might prefer to keep their right to seek an acquittal from a jury rather than to trade it for an uncertain reward. They might even flatter themselves with the hope that if they went to trial and lost, the judges still would not punish them severely. And conversely, why should Dana have dropped three charges and risked the possibility that the judges would, on the one remaining count, impose an overly lenient sentence? Had the judges been partners in these plea bargains and had they made their sentencing intentions clear, then any such reservation on Dana's or the defendants' part would have dissolved. But the record discloses no reason to think the judges took part in the deal.

In fact, neither Dana nor the defendants needed to worry that the judges might disappoint their expectations in the bargain, because the judges had no power to do so. The liquor law's penalty structure simply left them too little discretion. On a conviction of being a "common seller," as charged in count one of both indictments, the law prescribed a fine of twenty pounds exactly. ${ }^{36}$ Twenty pounds was a good deal of money, amounting at the time

34. Even in these very early years, the Coun of Common Pleas readily accepted pleas of guilty. In 1789-1790, there were 14 guilty pleas while there were only two pleas of no contest. In 1799-1800, there were nine guilty pleas and 12 pleas of no contest. Until the 1830 s, however, all of the clear plea bargains I saw in liquor cases involved pleas of no contest. Except in sparing defendants automatic liability in related civil cases, a plea of no contest had the same legal effect as a guilty plea:

It is only where the party is sued in a civil action for doing the thing for which he was indicted,... that the distinction between these pleas is material. The plea of nolo contendere pleaded with a protestation that the party was not guilty. would clearly not conclude the party in his defence against the civil action.

But so far as the Commonwealth is concerned, the judgment of conviction follows as well the one plea, as the other. And it is not necessary that the court should adjudge that the party was guilty, for that follows by necessary legal inference from the implied confession. But the court thereupon proceeds to pass the sentence of the law affixed to the crime.

Commonwealth v. Honon, 26 Mass. (9 Pick.) 206, 208 (1829).

35. See Commonwealth v. Andrews, 2 Mass. (1 Tyng) 408. 414 (1807) (" The Court never [enters a nolle prosequi], but at the instance of the counsel for the govemment.").

36. See Act of Feb. 28, 1787, ch. 68, 1786 Mass. Acts 206. 207. 
to almost sixty-seven dollars ${ }^{37}$ or more than the total in fines and costs paid by either defendant. The common-seller count therefore gave Dana real strength in any plea negotiation, for if the defendant risked trial and lost on that count, the court would have had no choice but to impose the statutory fine-whereas once Dana nol prossed the count in exchange for a plea, the court had no power to impose it. Although the license law prescribed a specific fine for almost every offense ${ }^{38}$ it did grant judges some sentencing discretion in cases of single unlicensed sales by providing for a fine of between two and six pounds. ${ }^{39}$ Despite the uncertainty injected into the outcome by this sentencing range, Dana and the defendants were able, if they chose, to agree in advance on the exact penalty the defendants would pay. For another statute gave Dana the power to determine the costs of prosecution, which the defendant had to pay. ${ }^{40}$ Costs often were several times greater than the statutory fines, so Dana's discretion to set costs was more than sufficient to offset any uncertainty about the judges' fines.

By depriving judges of almost all sentencing discretion in liquor-law cases, the legislature had assured that prosecutors could-by over-charging, selectively nol prossing, and manipulating the amount of costs-dictate the defendant's sentence. That is, the legislature had empowered prosecutors to engage in charge bargaining without fear that the court's noncooperation might unsettle the terms of the bargain. In no other statute of consequence to the daily practice of the middle-tier courts had the legislature bestowed such power on the prosecutor. Excepting only those very serious crimes that carried mandatory life or death sentences, none of the typical common-law offenses called for a minimum sentence. The penalty for petty larceny was zero to one year or a fine of zero to $\$ 300$; for grand larceny, it was zero to five years or zero to $\$ 600$; for breaking a shop at night, it was zero to twenty years; for forging a bank bill or unarmed robbery, it was zero to life. $^{41}$

37. On the exchange rate, see supra note 25 .

38. For being a common victualler, innholder, taverner, or seller, the penalty was 20 pounds. See 1786 Mass. Acts at 207 . For permitting a patron to drink to excess, for serving hard alcohol to minors or servants, or for serving to those identified by town selectmen as neglecting their families, the penalty was 20 shillings, or one pound. See id. at 210 . For serving to persons identified by the selectmen as common drunkards, the penalty was 30 shillings, or one and a half pounds. See id. at 214.

39. See id. at 210.

40. See MASS. REV. STAT. ch. 141, $\$ 8$ (Dutton \& Wentworth 1836) ("All costs, arising in criminal prosecutions, ... . shall be taxed by the attomey general, or by the district or county attomey, and the allowance thereof shall be certified by the clerk, under the direction of the court ....").

41. See id. ch. $125, \S 15$ (discussing unarmed robbery); id. ch. $126, \S 11$ (stating the penalties for shop breaking and entering); $i d$. ch. $126, \S 17$ (discussing the penalties for petty and grand larceny); id. ch. 127, $\S 4$ (discussing forgery). These penalties prevailed after 1836 . Before then, there were more crimes that carried mandatory penalties. Robbery, for example, carried mandatory life in prison. See Act of Mar. 16, 1805, ch. 143, § 7, 1804 Mass. Acts 240, 243. Prosecutors still could not take advantage of this rigidity, however, because it was not yet clearly 
In non-liquor cases, therefore, the prosecutor could not credibly threaten defendants with certain and steep punishment if they went to trial and lost, because the court's potential leniency had no bounds. True, the prosecutor had some power to limit the defendant's maximum exposure. At least after 1838, he could use a partial nol pros to reduce a charge of grand larceny to petty larceny and thereby guarantee defendants who pled guilty a maximum one-year sentence. ${ }^{42}$ But the records in the earlier half of my study rarely disclose such behavior, and we may presume that simply reducing the maximum exposure, when the lowered maximum still involved substantial prison time, usually was not sufficient to induce a defendant to plead. It is therefore no surprise that of the forty-nine clear plea bargains disclosed in the record books of the middle-tier courts during the years I studied between 1789 and 1849, thirty-three-or fully twothirds-took place in liquor cases. ${ }^{43}$ Put differently, clear plea bargains took

established that prosecutors had the power to enter partial nol prosses. In liquor cases, prosecutors could bring multiple charges and then nol pros whole counts of the complaint to reduce the defendant's sentence. As most robberies involved but a single allegation, the only way a prosecutor could contrive to lower the defendant's sentence was by reducing a greater charge to a lesser one by entering a nol pros as to part of the charge. It became clear only in 1838 that prosecutors had this power. See infra notes 107-115 and accompanying text.

42 See Commonwealth v. Tuck, 37 Mass. (20 Pick.) 356, 366 (1838) ("If the attomey general may enter a nolle prosequi as to the whole of an indictment, or of a count, so he may do it as to any distinct and substantive part of it."). The power to enter a partial nol pros was uncertain before this 1838 decision. See infra notes 107-115 and accompanying text.

43. Not all of the 16 non-liquor defendants whose cases ended in clear plea bargains benefited from pleading guilty in terms of a lower maximum porential penalty. I have already discussed the 1790 case of George Peters. See supra note 32. Other defendants, like Peters, were willing to plead, but only if the prosecutor first struck specific allegations as to which the defendant apparently maintained his innocence. Although these partial nol prosses lessened somewhat the seriousness of each case, there was no change in the formal designation of the defendant's crimes. See, e.g., Commonwealth v. Emerson Elwell, Middlesex C. C.P. R. Book 216 (June 1843) (reporting a breaking-and-entering case alleging the theft of 30 dozen saws, as to two dozen of which the prosecutor entered a nol pros); Commonwealth v. Benaiah S. Conner. Middlesex Ct. C.P. R. Book 2 (Feb. 1843) (reporting a petty larceny case in which a partial nol pros extended to some of the allegedly stolen goods); Commonwealth v. Timothy Peterson. Middlesex Ct. C.P. R. Book 218 (Nov. 1839) (same). 
place in twenty-four percent of adjudicated liquor cases, but in fewer than three percent of all other adjudicated cases. ${ }^{44}$

As the figures in note 44 show, however, Dana's tactic in Stevens and Corey did not become a favorite of Middlesex prosecutors until sometime in the 1840s. Asahel Stearns, who succeeded Dana as county attorney and held the office for some two decades, ${ }^{45}$ took a somewhat less aggressive tack in liquor cases. In 1824, for example, Stearns indicted twelve persons for violations of the liquor law. In three of these cases, he alleged multiple counts and exacted a plea bargain on the Stevens-Corey model. But in each of the remaining nine cases, he charged a single count of unlawful sale. ${ }^{\text {th }}$

44. These are my findings for the relevant years:

Clear Plea Bargains in Liquor and Non-Liquor Cases: MIDDLESEX COURT OF COMMON PLEAS AND ITS PREDECESSOR COURT

\begin{tabular}{|c|c|c|c|c|}
\hline \multirow{2}{*}{ YEAR } & \multicolumn{2}{|c|}{$\begin{array}{c}\text { NumBR OF ADJUDICATED } \\
\text { DEFENDANTS }\end{array}$} & \multicolumn{2}{c|}{$\begin{array}{c}\text { NUMBER OF CLEAR } \\
\text { PLEA BARGAINS }\end{array}$} \\
\hline & Non-Liquor & Liquor & Non-Liquor & Liquor \\
\hline $1789-1790^{*}$ & 21 & 1 & 1 & 0 \\
\hline $1799-1900^{*}$ & 30 & 2 & 0 & 0 \\
\hline $1805-1806^{*}$ & 39 & 0 & 0 & 0 \\
\hline $1809-1810^{*}$ & 27 & 1 & 0 & 1 \\
\hline $1814-1815^{*}$ & 36 & 0 & 2 & 0 \\
\hline $1819-1820^{*}$ & 41 & 5 & 1 & 1 \\
\hline 1824 & 27 & 12 & 1 & 3 \\
\hline 1829 & 18 & 9 & 0 & 0 \\
\hline 1834 & 58 & 7 & 0 & 4 \\
\hline 1839 & 35 & 1 & 1 & 0 \\
\hline $1843-1844^{*}$ & 135 & 42 & 8 & 4 \\
\hline 1849 & 167 & 56 & 2 & 20 \\
\hline \hline Total & 634 & 136 & 16 & 33 \\
\hline
\end{tabular}

* Two-year totals

Sources: Middlesex Ct. Gen. Sess. Peace R. Books; Middlesex Ct. Gen. Sess. Docket Books; Middlesex Ct. C.P. R. Books; Middlesex Ct. C.P. Docket Books.

By "liquor" cases, I mean cases brought under the liquor-license law, which I have described supra notes 22, 36-39 and accompanying text. By "non-liquor" cases, I mean cases in which the charge does not concern the sale or distribution of alcohol. In Appendix A. I trace out the line between liquor and non-liquor cases more exactly.

As I noted earlier, see supra note 29, "adjudicated" cases are those in which the defendant went to trial or pled guilty or no contest. Beginning in 1849, a great many cases at each term of court were placed "on file." As I will explain in Part III, see infra notes 289-381 and accompanying text, filed cases present a different aspect of the prosecutorial pleading power and must be considered separately. I therefore will be careful to note whether my figures for 1844 or any later year include filed cases. My figures for 1849 , listed in the table above, do not.

45. Though perhaps not continuously. See supra note 19.

46. It is often difficult to tell from the face of the record book whether a liquor case involved multiple counts. The clerk often noted only that the defendant was charged with a violation of "the License-law." See, e.g., Commonwealth v. John Wilson, Middlesex Ct. C.P. R. Book 79 (June 1853). The shorthand of the notation leaves one unable to conclude that only a single count was brought. For the nine cases just noted in the text, I have examined the indictments themselves. which are retained as part of the file papers and stored at the Massachusetts Archives. to confirm that there was just a single count. See Commonwealth v. John Wade \& Bowen Bucknam. Middlesex Ct. C.P. R. Book 405 (June 1824); Commonwealth v. William Rogers, Middlesex Ct. C.P. R. Book 404 (June 1824); Commonwealth v. Thomas Jameson, Middlesex Ct. C.P. R. Book 
The defendants in all nine cases readily pled either guilty or no contest, apparently regarding their seven-dollar fines and modest costs to be preferable to an expensive trial. In 1829, the next year I studied, Stearns resolved eight out of nine liquor cases in this manner.

I do not consider these cases to be clear plea bargains, for the record discloses no concession made in exchange for the defendant's plea. They may be examples of implicit plea bargains, however, in which the defendant offered a plea expecting that some concession would be made. ${ }^{.7}$ After all, the law empowered Stearns to set the costs of prosecution, and a trial no doubt would have inflated those costs. Stearns tried only two liquor cases in the years I studied, only one of which ended in a conviction. In that case, from 1820 , he assessed his defeated opponent costs of $\$ 39.85 .^{48}$ In the other liquor case that arose in the same term of the court, the defendant pled no contest, and Stearns put costs at just $\$ 23.21 .^{.9}$ And an assault-andbattery case Stearns prosecuted in 1814 makes even plainer how useful a plea-bargaining tool the cost-setting power could be: After the first of two co-defendants, Archibald McIntire, pled guilty and the second, William Fletcher, went to trial and lost, the court fined each five dollars. Spurning the court's even-handedness, Stearns put McIntire's costs at $\$ 4.76$ and Fletcher's at $\$ 39.53 .^{50}$

There is some reason to think that those liquor defendants who pled guilty or no contest in 1824 and 1829 had in mind the amount of costs Stearns might assess, for the records show a striking regularity in those amounts. Of the nine defendants from 1824 who pled either guilty or no

403 (June 1824); Commonwealth v. John Howe, Middlesex Ct. C.P. R. Book 402 (June 1824); Commonwealth v. Ebenezer Davis, Middlesex CL. C.P. R. Book 401 (June 1824): Commonwealth v. John Fowle, Middlesex Ct. C.P. R. Book 401 (June 1824); Commonwealth v. Andrew Cochran. Middlesex Cl. C.P. R. Book 400 (June 1824); Commonwealth v. Jacob Butters, Middlesex Ct. C.P. R. Book 399 (June 1824); Commonwealth v. Isaac Brooks, Middlesex C. C.P. R. Book 201 (Mar. 1824).

47. "Implicit plea bargaining takes place when a defendant pleads guilty without an explicit promise or deal, but knowing (or assuming) that better deals go to those who "cooperate" and spare the public the bother and expense of a trial." Lawrence M. Friedman. Courts over Time: A Survey of Theories and Research, in EMPIRICAL THEORIES ABOUT COURTS 9. 38 (Keith O. Boyum \& Lynn Mather eds., 1983). Raymond Moley recognized the phenomenon a good many years ago. See Raymond Moley, The Vanishing Jun, 2 S. CAL. L. REV. 97, 103 (1928) (noting that the defendant may plead in exchange for an "expressed or implied assurance" of a concession).

48. The conviction took place in Connonwealth v. Josiah Howard, Middlesex Ct. C.P. R. Book 241 (Mar. 1820). Stearns's other liquor trial ended in an acquittal. See Commonwealth v. John Houch, Middlesex Ct. C.P. R. Book 685 (Dec. 1829). Although in some jurisdictions, costs could be assessed even after an acquittal, that was not the case in Massachusetts during the period of my study. In a 1799 case resulting in a not-guilty verdict, the records make clear that costs were to be paid by the county. See Commonwealth v. John Johnson, Middlesex $\mathrm{Ct}$. Gen. Sess. Peace R. Book 432 (Mar. 1799). 1820).

49. See Commonwealth v. Jacob Carter, Middlesex Ci. Gen. Sess. Peace R. Book 244 (Mar.

50. See Commonwealth v. William Fletcher \& Archibald Mclntire, Middlesex Ct. C.P. R. Book 174 (Mar. 1814). 
contest and won no obvious concession, six were assessed costs of $\$ 13.77$, two costs of $\$ 14.77$, and one costs of $\$ 14.97$. Of the eight defendants in this category from 1829 , three were assessed costs of $\$ 11.49$ and two costs of $\$ 18.14{ }^{51}$ There is little reason to think that Stearns manipulated the amount of costs to induce defendants to plead. Rather, the most likely explanation for assessing different defendants the same, very specific figures is that Stearns pooled the costs of prosecuting liquor cases from a particular town and divided them among all the liquor defendants from that town who offered a plea. $^{52}$ This practice assured that defendants could know in advance the amount of costs they faced if they offered a plea. The record books disclose that in 1824 six of the nine defendants just mentioned had lawyers-and all but one of them the same lawyer-who no doubt could have helped the clients predict the consequences of their pleas. ${ }^{33}$

The power to set the costs of prosecution was perhaps a more potent plea-bargaining tool in liquor cases than in others. By custom, if not by law, prosecutors rarely assessed costs when a convict was sent to prison. ${ }^{54}$ Because the liquor law did not call for imprisonment except on a second or third offense before the second half of the century, ${ }^{55}$ costs were an almost invariable part of the disposition. And as a proportion of the total penalty, costs loomed large in liquor cases, in which the customary fine for making a single unlicensed sale was seven dollars, and costs were consistently more. At all events, Stearns was able to use cost-setting and, to a lesser extent, Dana's multiple-charge tactic as well as other stratagems to win pleas from twenty-four of the thirty-three liquor defendants he prosecuted in the years I studied. He went to trial only twice and nol prossed charges without winning pleas in seven cases. In contrast, of 224 non-liquor cases that Stearns prosecuted in these years, he resolved only eighty-one by plea

51. In two cases, the costs were unspecified, and in one, they were set at $\$ 9.97$.

52. The records bear this theory out. In all of the cases just noted, defendants who paid the same costs came from either the same or contiguous towns. I have examined Stearns's accounting of costs in the file papers for several of these cases and have noted nothing that seems contrived or fudged.

53. Throughout the period of my study, it was quite unusual for the record books to disclose the presence of counsel. The court's docket books regularly recorded counsel beginning only in 1844. I will argue in Part IV that the rate of representation before that time was probably a good deal less than $50 \%$. See infra notes $435-440$ and accompanying text.

54. In the eight years of his tenure that I studied-1809 (second half), 1810, 1814, 1815, $1819,1820,1824$, and 1829-Stearns asked for costs in only four of the 48 cases in which defendants served time. For examples of the anomalous cases, see Commonwealth v. Nathaniel Gilson, Middlesex Ct. C.P. R. Book 515 (Dec. 1809), a theft case in which the defendant was sentenced to two months in jail and was assessed costs of $\$ 29.66$, and Commonwealth v. Timothy Cole, Middlesex Ct. C.P. R. Book 370 (June 1814), a theft case in which the defendant was sentenced to 20 days in jail and a fine of $\$ 20$ and was assessed costs of $\$ 39.98$. It was certainly true, however, that for nonpayment of costs, defendants often found themselves locked up. In fact. the typical sentence commanded that the defendant be committed until costs were paid.

55. The license law of 1832 made second offenders liable to a term of up to 90 days. See Act of Mar. 24, 1832, ch. 166, $\S 15,1832$ Mass. Acts 473, 481-82. An act of 1855 made prison time mandatory even for a first offense. See infra note 289 and accompanying text. 
(and only four by clear plea bargains), took sixty-three to trial, and abandoned prosecution by entering nol prosses in most of the rest.

If Asahel Huntington, who succeeded Stearns in about $1832,{ }^{36}$ proved to be even more resourceful in managing his liquor caseload, it was perhaps because he had to be. In 1834, the first year I studied of Huntington's tenure, he prosecuted ninety-five cases of all types, more than double the forty-one cases Stearns handled in 1829. And that was just in Middlesex County. An 1832 statute had split the state into districts, so Huntington took on the new title of district attorney and assumed an enlarged realm that included Essex County, Middlesex's smaller but still substantial neighbor.

Within two years, Huntington had begun to formulate his signature contribution to plea-bargaining technology: the preprinted, multi-count liquor-indictment form. He deployed several primitive versions of this device in 1834. In the case of Samuel Elliot, he used a preprinted indictment form that alleged four counts of making single unlicensed alcohol sales. Huntingtọn filled in Elliot's name, the relevant dates and places, and other information peculiar to Elliot's offense. His use of a preprinted form suggests that far from tailoring the charges to Elliot's specific acts, Huntington had embraced a routine practice of charging multiple counts of unlicensed sales. Facing this four-count indictment, Elliot chose to plead no contest on two counts in exchange for Huntington's nol pros of the other two. ${ }^{57}$ In the case of Amos Adams, Huntington pasted together two of these four-count forms. Adams pled guilty to count one, and Huntington nol prossed counts two through eight. ${ }^{58}$ In several other cases, Huntington used a preprinted form that alleged one count of being a common seller and one count of making a single sale, to which he often appended an additional, handwritten single-sale count. 59

Huntington's multi-count liquor forms grew more sophisticated with time. Figure 1 reproduces one such form from 1843. In the first of five counts, it charges the defendants, Henry and Albert Sprague of Cambridge, with being common sellers of alcohol. Count two alleges a single sale, and

56. Charles Warren reponted that Steams served until 1832. See I CHARLES WARREN, HISTORY OF THE HARVARD LAW SCHOOL AND OF EARLY LEGAL CONDITONS IN AMIERICA 313 (1908). I have found no source giving the dates of Huntington's service. He was certainly in place as of 1834. See Middlesex Ct. C.P. R. Book 263 (Mar. 1834).

57. See Commonwealth v. Samuel Elliot, Middlesex C. C.P. R. Book 327 (Sept. 1834) (indictment form on file with the Massachusetts Archives).

58. See Commonwealth v. Amos Adams, Middlesex CL C.P. R. Book 477 (Dec. 1834) (indictment form on file with the Massachusetts Archives).

59. See, e.g., Commonwealth v. Patrick Maurice. Middlesex C. C.P. R. Book 336 (Sept. 1834) (indictment form on file with the Massachusetts Archives). Maurice pled guilty to one count of making a single sale, and Huntington nol prossed the other two counts. See id. 
FIGURE 1. HUNTINGTON'S MULTI-COUNT LIQUOR FORM

Uommonwealty of Alassaclingetts.

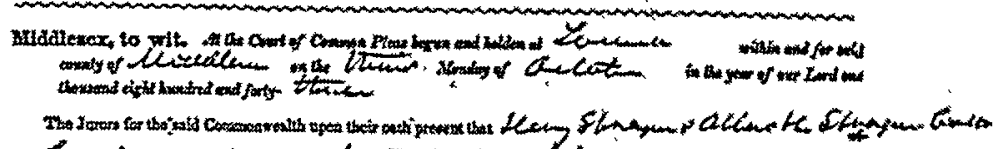

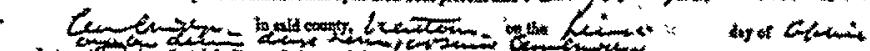

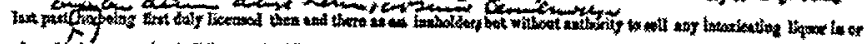

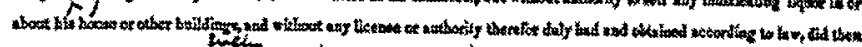

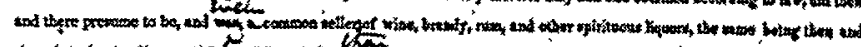

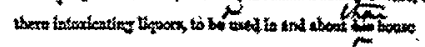

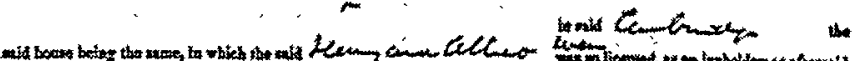

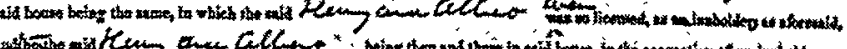

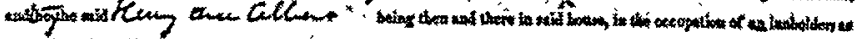

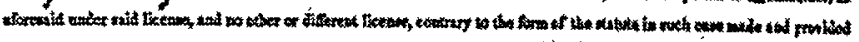

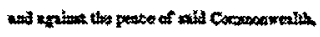

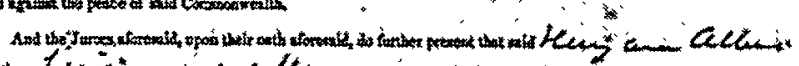

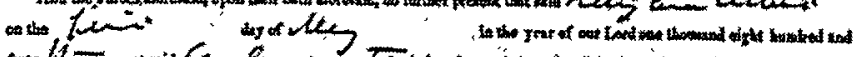

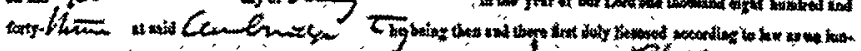

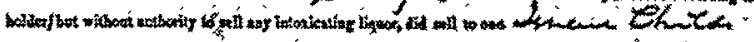

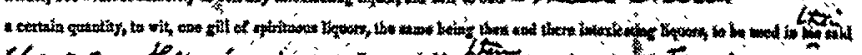

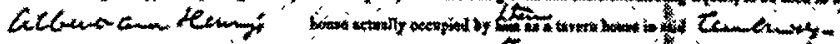

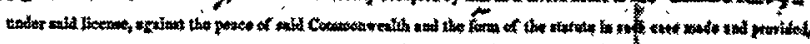

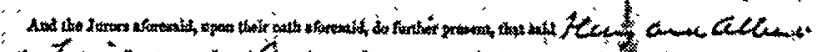

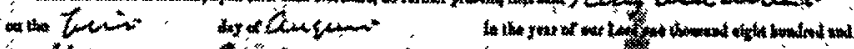

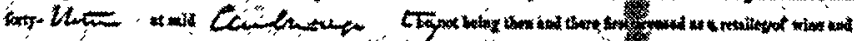

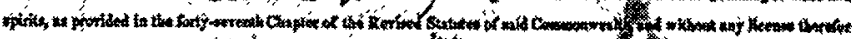

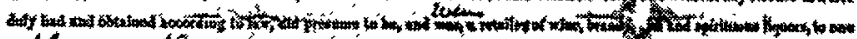

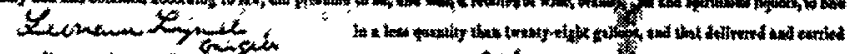

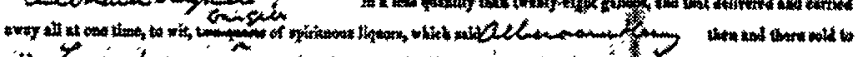

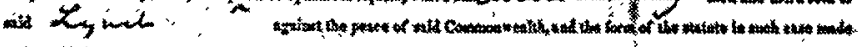
axal perpation.

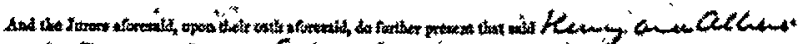

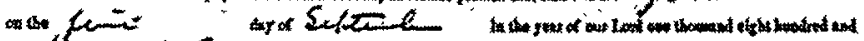

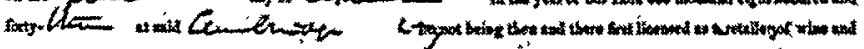

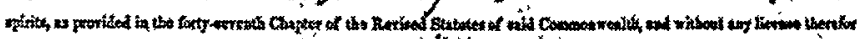

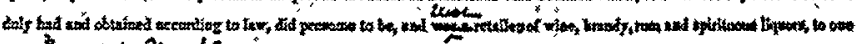

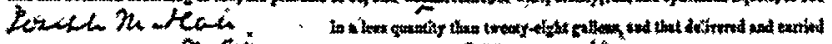

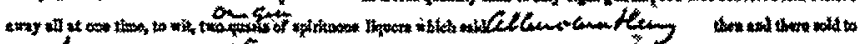

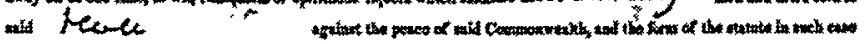

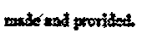

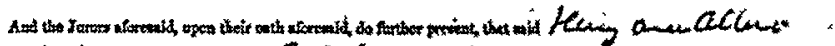

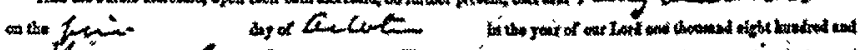

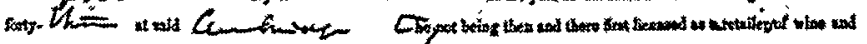

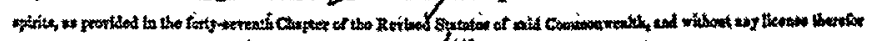

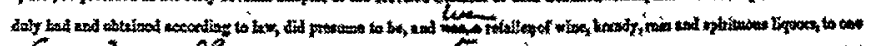

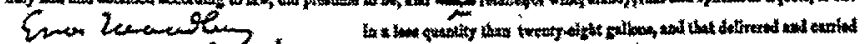

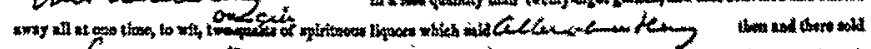

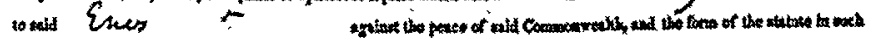
$\operatorname{cacos}$ de wad provided

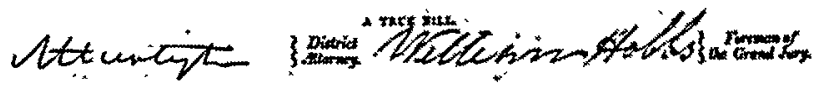


counts three through five allege being an unlicensed retailer ${ }^{60}$ As revised in the state's 1836 code, the license law punished the first of these offenses by a fine of $\$ 100$ and each of the last four by fines of twenty dollars exactly. ${ }^{61}$ A defendant who dared risk trial on such an indictment could not hope for leniency if convicted, for the judge had no discretion in sentencing. This was the sad discovery of Daniel McCrillis, who in 1849 was convicted of four counts, fined $\$ 160$, and assessed costs of $\$ 88.05 .^{62}$ Those defendants who chose instead to fight another day and pled to one or more of the twenty-dollar counts regularly secured nol prosses on at least the first and most expensive count and paid moderate costs of between twenty and forty dollars. ${ }^{63}$ Huntington had complete discretion to reward defendants in this way. As the Supreme Judicial Court wrote in 1838, "[I]t is perfectly clear that a nolle prosequi may be entered [before trial] at the pleasure of the prosecuting officer. ... The Court has no right to interfere ...."

However useful Huntington's multi-count forms and liberal nol prossing practices may have been in managing his liquor caseload, their virtues did not immediately appear to the legislators who discovered his doings sometime in 1843 or early 1844 . A House investigating committee summoned Huntington to respond to two sets of charges. The first alleged simple graft-that Huntington had received fines and court costs from defendants and failed to pay the whole amount over to the state. ${ }^{65}$ The second alleged "mal-administration... [i]n taking less than might have been required on the discharge of indictments found and not tried." ${ }^{\circ}$ These charges, the committee noted, "all relate to [Huntington's] official administration of the laws of the Commonwealth, against selling spirituous

60. See Commonwealth v. Henry Sprague \& Alben H. Sprague. Middlesex C. C.P. R. Book 423 (Oct. 1843) (indictment form on file with the Massachusetts Archives).

61. See MASS. REV. STAT. ch. 47, §§ 1-4 (Dutton \& Wentworth 1836). Like the 1787 license law, see supra notes 22,36-39 and accompanying text. the 1836 code called for mandatory

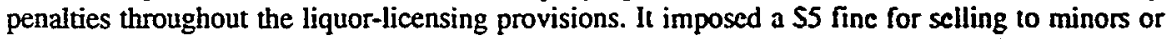
servants, a \$10 fine (even if licensed) for selling on Sundays, and a \$20 fine for selling to persons cut off by town selectmen. See MASS. REV. STAT. ch. 47, $\$ 11,13,15-16$. Only in the case of second offenders, whom the court had the discretion to sentence to up to 90 days in the common jail, did the act create any flexibility in sentencing. See id. $\$ 29$. But second-offender prosecutions were exceedingly rare.

62. See Commonwealth v. Daniel McCrillis. Middlesex C. C.P. R. Book S2l (June 1849).

63. See, e.g., Commonwealth v. Daniel L. Richardson, Middlescx C. C.P. R. Book 611 (Oct. 1849) (reporting a case in which the defendant pled to two $\$ 20$ counts and was fined $\$ 40$ and assessed court costs of \$35).

64. Commonwealth v. Tuck, 37 Mass. (20 Pick.) 356, 365-66 (1838).

65. See CASE OF ASAHEL HUNTINGTON: REPORT, H. DOC. NO. 4, al 3-5 (Mass. 1845). Robert Hampel seems to be the first modem scholar to cite the Huntington case. See ROBERT L. HAMPEL, TEMPERANCE AND PROHIBITION IN MASSACHUSETTS, 1813-1852, at $214 \mathrm{n} .11$ (1982).

66. H. DOC. No. 4, at 7. The original complaint by Representative Cynus Washbum of Lynn. in Essex County, was slightly more pointed: It specifically alleged that Huntington "discharg[ed] the said Defendants on his own responsibility without a trial." ORDER FOR COMAMITIEE Of AsAHEl Huntington, H. DOC. No. 1499, at 2 (Mass. 1844) (on file with the Massachusets Archives). 
liquors without license." 67 It appears the committee was reacting in part to the September 1842 sitting of the Court of Common Pleas in Essex County, at which Huntington managed to dispose of all eighteen of his liquor cases without a trial. ${ }^{68}$

Shocked to find plea bargaining going on in the Commonwealth's courts, the committee demanded that Huntington appear and explain himself. He denied the allegations of graft, and the committee ultimately deemed those charges unsupported. ${ }^{69}$ As for the charges of malpractice by plea bargaining, Huntington stoutly admitted that they "were true in fact," and "he claimed the right under the laws of the Commonwealth" to do exactly as the committee alleged. ${ }^{70}$ Then he offered the legislators a pleabargaining primer for use in liquor-license cases, which began with his acknowledgment of the practice of multiple charging:

[W] henever a number of penalties had been demanded in different counts of the same indictment, and the defendant came forward and proposed an adjustment, [Huntington's] usual course had been-

1 st. To require the party to enter a plea of nolo contendere.

2d. To enter into an agreement to abstain from future sales of liquors without license.

3d. To pay at least one penalty to the Commonwealth, and all costs which had then accrued. And

4th. That the indictment should then stand continued as security that the defendant would fulfil his agreement, and to be further prosecuted in case the defendant still continued in his course of a wilful violation of the laws."

I will return to the significance of steps two and four of this method in Part III when I take up the origins of prosecutorial probation. In steps one and three, Huntington merely adopted and institutionalized the plea-bargaining approach Dana had put to use in 1808.

67. H. Doc. No. 4 , at 7.

68. The Committee's report lists 16 witnesses to the allegations of plea bargaining. See id. at 5. I have been able to identify only three. Two were defendants in liquor cases heard in the March 1842 session of the Essex Court of Common Pleas. See Commonwealth v. Joshua Peckham, Essex Ct. C.P. R. Book 124 (Mar. 1842); Commonwealth v. John N. Martin, Essex Ct. C.P. R. Book 124 (Mar. 1842). One of these and one other appeared as liquor defendants in the September term of the same court. See Commonwealth v. Joseph Perley, Essex Ct. C.P. R. Book 105 (Sept. 1842); Commonwealth v. John N. Martin, Essex Ct. C.P. R. Book 105 (Sept. 1842). In the March term, Huntington had seven liquor cases, and although he consistently charged multiple counts, he was forced to trial in five of them (the two just cited being the exceptions). In the September term. when Huntington had 18 liquor cases, his tactics were more successful. He charged all but two liquor defendants with multiple counts, secured pleas of no contest in all but five cases, entered nol prosses on payment of costs in four, and nol prossed the last case outright.

69. See H. Doc. No. 4, at 8-10.

70. Id. at 6-7.

71. Id. at $7-8$. 
Huntington contended that in light of his crushing workload, this procedure was "most conducive to the public interest." ${ }^{2}$ The legislature had eliminated the office of attorney general in $1843,{ }^{73}$ leaving the various district attorneys saddled with "the entire direction and management of all prosecutions and suits in behalf of the Commonwealth." ${ }^{74}$ And there was nothing sneaky about his plea-bargaining tactics: "It was very distinctly in evidence," the committee allowed, "that this course was taken openly and publicly ... and impartially applied to all; that it was known to the Courts, the Bar, the County Commissioners, and all other persons who had occasion to take any interest in the administration of this department of the law." 75 In the end, Huntington wholly won over the committee, whose report overflowed with his "extraordinary zeal and untiring industry"; his "intelligence, integrity, fidelity and ability"; his "arduous and exhausting" and "severe and long continued exertions"; and his devotion "even to the peril of his life" - for Huntington had been sick from overwork-" to the discharge of his official duties." 76 The committee was barely less florid in its praise of Huntington's method of plea bargaining in liquor cases, which it said "tend[ed] more than any other course in the class of cases to which it was applied, to attain the just end of all punishment, the prevention of the offence, the reformation of the offender." 7

Despite the committee's vindication, announced in January 1845 , Huntington departed from office later the same year because (it was said) he found his salary inadequate to his labors. ${ }^{78}$ His successor perhaps took courage in the legislature's lavish endorsement of Huntington's tactics, for he dispatched his liquor cases in an even more brazenly public manner. Hence we find this notice concerning district attorney Albert Nelson in the Lowell Journal of April 2, 1847:

LICENSE CASES. The Newburyport Advertiser says that Mr. Nelson, Attorney for the Essex and Middlesex district, states that at the present term, it is his intention when the parties complained of plead guilty, and enter into recognizance to observe the law, not to press for the fines which are incurred, but simply to exact the costs of Court. At the next term, however, he announces that no more

72. Id. at 7.

73. See Act of Mar. 24, 1843, ch. 99, 1843 Mass. Acts 60.

74. H. Doc. No. 4 , at 7 .

75. Id. at 8.

76. Id. at 9 .

77. Id. at 8 .

78. It appears that Albert H. Nelson took office as district attomey in December 1845. The Lowell Courier noted his appointment on December 10. 1845. See Albert H. Nelson, Esq., LOWELL DAILY COURIER, Dec. 10,1845, at 2. A correspondent to the Lowell Joumal is the source of the supposition that Huntington "felt constrained to resign on account of the inadequacy of the salary." Lowell J., Oct. 8, 1847, at 1 . On the several district attomeys' disgruntlement with their workloads and salaries, see infra notes 132-145 and accompanying text. 
settlements of cases will be made; but that full fines will be exacted in every case where the parties are convicted. ${ }^{79}$

I will take up in Part III how it was that Nelson could promise not to exact fines against defendants who pled guilty under a statute that mandated fines. For now, the significance of this mid-century announcement of a district attorney's fire sale in liquor-license cases is Nelson's manifest confidence in his own power to make such promises without concern about possible interference from the court.

Charles Russell Train, who followed Nelson into office in $1848,{ }^{80}$ proved to be the most enthusiastic of Middlesex's early plea-bargaining practitioners. Train quickly mastered the plea bargainer's art and deployed the Dana-Stevens-Corey model of charge bargaining and Huntington's preprinted, multi-count liquor-indictment forms with unprecedented regularity. In 1849, Train charged multiple counts in eighty-nine percent of his liquor indictments and managed to resolve twenty of fifty-six adjudicated liquor cases with clear plea bargains. All but one were built upon multi-count indictments, the district attorney's nol pros of selected counts, and the defendant's plea of guilty to the rest. ${ }^{81}$

79. License Cases, Lowell J., Apr. 2, 1847, at 2. Lowell is one of the prominent cities of Middlesex County. Newburyport is in Essex County and, although not large, was the site of one of the four annual sittings of the Court of Common Pleas in that county. The two counties together formed the Northern District, of which Nelson was district attorney. Tami Swiger, one of my research assistants, spotted this notice of Nelson's practice.

80. Nelson made his last appearance in the Court of Common Pleas Record Books in the October 1847 session; Train made his first in February 1848. See Middlesex Ct. C.P. R. Book (Feb. 1848) (on file with the Massachusetts Archives); Middlesex Ct. C.P. R. Book (Oct. 1847) (on file with the Massachusetts Archives).

81. The one exception is Commonwealth v. Charles McDermot, Middlesex Ct. C.P. R. Book 448 (Feb. 1849). McDermot was charged with six liquor counts on a preprinted form. As far as the records indicate, he offered a general guilty plea, but was sentenced on only two counts and fined $\$ 20$ on each. The records do not specify that Train nol prossed the remaining counts. I might have hesitated to call this case a clear plea bargain, but the court's docket book specifically noted that the case was disposed of "without costs," id., which was a sufficiently rare concession, taken together with the other circumstances, that I felt justified to include this case with the other.

Another seven of Train's 1849 liquor cases look very much like clear plea bargains-_-but not enough so for me to count them as such. Most took the form of Commonwealth v. Jonathan $M$. Marston, Middlesex Ct. C.P. R. Book 437 (Feb. 1849). Marston was charged with one count of being a common seller (carrying a $\$ 100$ fine) and two counts of making single sales (cach carrying a $\$ 20$ fine). He pled guilty, but the record does not say whether he pled to all counts. He was fined $\$ 100$ and assessed an unspecified amount of court costs. We may infer Marston was convicted only of the common-seller count, but there is no sign of what happened to the other counts. Because the defendant paid a fine on the most expensive count, and because the record makes no explicit statement that the district attorney nol prossed the other counts, I have decided not to consider Marston's case or the others like it to be clear plea bargains. I have also excluded on-file plea bargains from the 20 cases noted in the text. These will be the topic of Part III. 


\section{B. Charge Bargaining in Murder Cases}

Train was therefore the fifth in a chain of Middlesex prosecutors, beginning with Dana and running through Stearns, Huntington, and Nelson, to exploit an extraordinary power to craft deals in liquor cases. He appears to have been the first Middlesex prosecutor to make use of an analogous, if less precise, power to cut deals in capital cases. I mentioned earlier that the legislature abolished the office of attorney general in $1843 .^{82}$ For six years, before the legislature relented and reinstated the office, ${ }^{83}$ the various county prosecutors took on the task of trying capital cases before the Supreme Judicial Court. During their six years before the high court, Middlesex prosecutors conducted three capital trials. In his only murder trial, Huntington won a manslaughter verdict and a seven-year prison sentence. ${ }^{84}$ One of Nelson's two trials ended in a conviction and death sentence, ${ }^{85}$ the other in a verdict of not guilty by reason of insanity. ${ }^{86}$

Train had a single capital case before the court-in October 1848-and he avoided trial with a plea-bargaining technique very similar to the one he used in liquor cases before the Court of Common Pleas. Barney Goulding stood charged with murdering his wife, Ellen, by beating her about the head ${ }^{87}$ He pled not guilty at his arraignment and claimed his right to a jury trial. Under a Massachusetts law that granted counsel to capital defendants, the court assigned two prominent members of the Middlesex bar to defend him. ${ }^{88}$ The clerk recorded what happened next:

And afterward in this same term the said Barney Goulding, otherwise called Barnett Goulding, retracts his [not guilty] plea above pleaded, and says he is guilty of manslaughter. And Charles R. Train, Esquire, attorney for the Commonwealth in this behalf, says, he will no further prosecute this indictment as to the malice aforethought, and the charge of murder. ${ }^{89}$

82. See Act of Mar. 24, 1843, ch. 99, 1843 Mass. Acts 60.

83. See Act of May 1, 1849, ch. 186, 1849 Mass. Acts 117.

84. See Commonwealth v. William Goldsmith, Sup. Jud. C. R. Book 456 (Middlesex, Apr. 1845).

85. See Commonwealth v. George Hunnewell, Sup. Jud. Cl. R. Book 102 (Middlesex, Oct. 1847).

86. See Commonwealth v. Alexander Roy, Sup. Jud. Ct. R. Book 103 (Middlesex, Oct. 1847).

87. See Commonwealth v. Barney Goulding. Sup. Jud. CL. R. Book 226 (Middlesex. Oct. 1848); LOWELL J., Mar. 24, 1848, at 4.

88. See Goulding, Sup. Jud. Ct. R. Book at 228 (reporting the appointments of Benjamin F. Butler and Theodore H. Sweetser).

89. Id. 
On his manslaughter conviction, the court sentenced Goulding to two years in the house of correction. ${ }^{90}$

Had Goulding insisted on trial and been convicted of murder, he would have faced the mandatory penalty of death. The legislature did not divide murder into degrees until 1858, and until then all murder remained capital. Train's generosity in nol prossing so much of the murder indictment as charged more than manslaughter shrank Goulding's possible sentence to a term of between zero and twenty years in prison. The judge, as the clerk reported, hewed to the bottom of that range.

Train's was not the first clear plea bargain in a capital case in Massachusetts, though it does appear to have been among the first. As early as 1804, the Supreme Judicial Court, sitting in its capacity as a trial court, accepted a guilty plea in a murder case. That plea was far from a bargain, however, as it merely secured the defendant's compulsory executionperhaps explaining the Court's insistence that the defendant reconsider before it recorded his plea. ${ }^{91}$ The earliest clear plea bargains I have found in capital cases took place in $1841 .^{92}$ Attorney General James Austin

90. See id.

91. See Commonwealth v. Battis, 1 Mass. (1 Will.) 94, 94-95 (1804). I have come across four other pleas to capital charges in the 19th century. See Commonwealth v. Edwin Ray Snow, listed in Report of the Attorney General for the Year Ending January 17, 1900, PUB. DOC. NO. 12, at xii (Mass. 1900); Commonwealth v. Daniel Gleason, listed in Report of the Attorney General for the Year Ending December 31, 1872, PuB. DOC. No. 12, at 5-6 (Mass. 1873); Green v. Commonwealth, 94 Mass. (12 Allen) 155, 157 (Mass. 1866); Commonwealth v. Edward W. Green, listed in Report of the Attorney General for the Year Ending December 31. 1864. PUB. Doc. No. 14, at 12 (Mass. 1865); Commonwealth v. John Roach, Sup. Jud. Ct. R. Book 682 (Worcester, Sept. 1845).

In the Gleason and Snow cases, the governor commuted the defendants' death sentences to life in prison. The attorney general's report of the Gleason case gave no reason for the commutation, but in Snow, the attorney general said he had recommended a commutation because the defendant was only 17 at the time of the murder in question. See Snow, PUB. DOC. No. 12, at xii. Although it is possible that Snow pled guilty in exchange for the attorney general's promise to recommend commutation, this purposeful seems unlikely, because the parties could have accomplished the same result-life in prison-with a second-degree murder deal, and because the prosecutor presumably could not guarantee the governor's action.

In the first half of the 19th century, about $20 \%$ of state-prison inmates in Massachusetts were released by governors' pardons. See William Francis KUNTZ II, CRIMINAL SENTENCING IN THREE NINETEENTH-CENTURY CITIES: SOCIAL HISTORY OF PUNISHMENT IN NEW YORK. BOSTON, AND PHILADELPHIA 1830-1880, at 124-25 (1988). Because I have not seen cvidence that defendants pled guilty in anticipation of such forgiveness, I have not included the pardoning power in this study. For more on guilty pleas in capital cases, see infra notes $423,426-428$ and accompanying text.

92. It is quite possible that other plea bargains escaped my notice. The attorney general began to produce comprehensive accounts of his business before the Supreme Judicial Court in 1832 . My examination of his reports disclosed no plea bargaining in capital cases between 1832 and 1841. I have examined the Supreme Judicial Court's own records of its criminal business in Suffolk County, which generated far more capital cases than any other county, between 1820 and 1832, as well as the records of its criminal business in Middlesex County during 1799. 1809. 1819,1824 , and 1829 . In none of these records did I find any evidence of plea bargaining in capital cases-but the state contained many other criminal jurisdictions, and I left many other years unexamined. 
negotiated two such bargains before the Supreme Judicial Court that year. In one, a murder case, the bargain took much the same form as in Train's Goulding case. ${ }^{93}$ In the second, charging rape, the defendant pled guilty to assault with intent to rape. Austin then nol prossed "the other and further part of the indictment" - that is, so much of the indictment as charged an actual rape. ${ }^{94}$ Rape, like murder, carried mandatory death, while assault with intent to rape carried any term of years up to life in prison. In this case the judge sentenced the defendant to five years in prison. Rape soon ceased to be a capital offense-by 1852 , murder was virtually the only crime still deemed capital ${ }^{95}$ - and every other charge bargain I encountered in a capital case involved the crime of murder.

There was one other capital charge bargain during the 1840s-this one in a murder case prosecuted by the district attorney of the Southern District, John H. Clifford, in $1845 .^{96}$ Together, these four charge bargains by Train, Austin, and Clifford accounted for ten percent of all adjudicated capital cases in my survey of Supreme Judicial Court business in the $1840 \mathrm{~s}^{.7}$ In the 1850s-when Clifford, now attorney general, handled most murder prosecutions ${ }^{98}$ - seventeen percent of adjudicated murder cases ended in charge bargains of this sort. Then in the 1860s, the trend turned sharply upward. Twenty-five of fifty-three murder cases - or forty-seven percentended in charge bargains. Although the rate of charge bargaining retreated somewhat to forty-three percent in the 1870s and thirty-five percent in the 1880 s, the 1890 s closed the century with a record sixty-one percent of

93. See Commonwealth v. Susan Boston, Sup. Jud. Ct. R. Book 152 (Bristol, Apr. 1841). Boston, charged with murdering a man with a knife, pled guilty to manslaughter. Austin nol prossed so much of the complaint as charged murder, and the court sentenced Boston to three years in the house of correction. See id.

94. See Commonwealth v. Michael Larry, Sup. Jud. C. R. Book 363 (Suffolk, Nov. 1841).

95. It appears that the only other capital crime was an official's voluntary and wrongful release of a capital prisoner-an offense that the Supreme Judicial Court noted in 1866 had never, to the court's knowledge, been committed. See Green, 94 Mass. (12 Allen) at 168.

96. See Commonwealth v. John Cunningham, Sup. Jud. C. R. Book 46 (Bristol, Nov. 1845).

97. Although the office of attomey general was not abolished until 1843, the attomey general for some reason stopped producing annual accounts of the cases he prosecuted before the high court in 1839 and did not resume until 1849. For each of the intervening years, I examined the Supreme Judicial Court's own records of its sittings in the counties of Suffolk. Middlesex. Bristol. Hampden, Norfolk, and Worcester. Although this survey excluded eight other counties, most of those eight generated little criminal business.

98. Clifford served as attomey general from 1849 , when the office was reinstated, until 1853 , when he left the post to become governor, and then again from 1854 until 1858. See I Davis, supra note 14, at 290; DAVIS, supra note 7, at 286. 
murder cases ending in charge bargains. ${ }^{99}$ In contrast, the rate of charge bargaining in all other non-liquor prosecutions never exceeded eleven percent of adjudicated cases in any one year, ${ }^{100}$ and across all years stood at just three percent. ${ }^{101}$

At least three moments in this chronology of plea bargaining in murder cases seem to require some explanation: Why, first of all, did bargains in capital cases emerge in 1841 and not earlier? Why did they advance so dramatically in the 1860s? And why, after some slackening, did they advance so vigorously in the 1890s? The last question is best left until later, when we move into the last quarter of the century. I will take up the first two questions now.

At one level, it is surprising to learn that plea bargaining in capital cases emerged as early as 1841 . It is true that scattered instances of plea bargaining, even in serious cases, crop up quite early in the historical record-I will consider these in more detail in Part VI. But Austin's 1841 charge bargains were not two scattered instances, but rather the beginning of a regular practice of charge bargaining in murder cases that, within three decades, accounted for nearly half of all murder cases and that persisted

99. These are my findings for the relevant years:

Clear Plea Bargains in Murder Cases SUPREME JUDICIAL COURT

\begin{tabular}{|c|c|c|c|}
\hline DECADE & $\begin{array}{c}\text { NUMBER OF ADJUDICATED } \\
\text { MURDER CASES }\end{array}$ & $\begin{array}{c}\text { NUMBER OF ClEAR } \\
\text { PLEA BARGAINS }\end{array}$ & $\begin{array}{c}\text { BARGAINS AS \% } \\
\text { OF TOTAL. }\end{array}$ \\
\hline $1840 \mathrm{~s}$ & $41^{*}$ & 4 & 10 \\
\hline $1850 \mathrm{~s}$ & $42^{*}$ & 7 & 17 \\
\hline $1860 \mathrm{~s}$ & 53 & 25 & 47 \\
\hline $1870 \mathrm{~s}$ & 77 & 33 & 43 \\
\hline $1880 \mathrm{~s}$ & 51 & 18 & 35 \\
\hline $1890 \mathrm{~s}$ & 67 & 41 & 61 \\
\hline
\end{tabular}

* Figures from the 1860s through the 1890 s are based on the attorney general's annual summaries of his work and therefore should include all murder prosecutions. As the attorney general either did not exist or produced no summary of cases from 1840 to 1848 or in 1853, figures for those years are based on a study of the Supreme Judicial Court's record books for its sittings in Suffolk, Middlesex, Bristol, Hampden, Norfolk. and Worcester counties. From 1851 onward, murder accounted for all capital cases. In the earlier years, rape, arson, burglary, and armed robbery also appeared on the Supreme Judicial Court's dockets, but the only clear plea bargain involving any crime other than murder was the rape case noted earlier in the text. See supra notes $94-95$ and accompanying text.

Sources: Annual Reports of the Attomey General; Sup. Jud. Ct. R. Books.

I have found no reported case and no commentary, judicial or otherwise, bearing on thesc prosecutorial charge bargains in murder cases. It is the nature of prosecutorial charge bargains that they require no judicial cooperation and that indeed judges have little power to interfere. Still, the absence of negative comment by the Supreme Judicial Court, which of course presided over pleas in murder cases, casts doubt on the general claim that "appellate courts accepted [plea bargaining] only after almost a century of severe disapproval." Alschuler, supra note 2, at 19 n. 106.

100. In 1844 , the figure fell just shy of $10 \%$. The single charge bargain in 1790 , see supra note 32 , amounted to $11 \%$ of that year's nine adjudicated non-liquor cases. As I noted earlier, it is not altogether clear that this case should be considered a charge bargain at all. See supra note 32.

101. I am not including filed cases, the topic of Part III, in this calculation. 
through the balance of the century. This early timetable challenges the views of some who argue that nineteenth-century courts resisted plea bargaining and discouraged its rise until at least the late nineteenth or even early twentieth century. ${ }^{102}$ But in the context of my arguments here, 1841 seems rather late for the first such bargains to emerge. After all, charge bargains in liquor cases appeared as early as 1808, only one year after the appointment of the first county prosecutor, and they took place in some of the very first liquor cases heard by the Court of Common Pleas. ${ }^{103}$ These early deals seem to have been the product of a nearly instantaneous reaction of two chemical ingredients-the existence of a public prosecutor and the prosecutor's power to bargain, conferred by the liquor law's rigid penalty scheme.

There are several reasons to expect that charge bargains might have proved rarer in murder cases than in liquor cases. Perhaps the most obvious is that prosecutors might have felt that both justice and public opinion demanded a full measure of punishment in murder cases. Trading the mandatory death penalty assigned to murder for the uncertain zero-totwenty-year prison term assigned to manslaughter might have offended basic prosecutorial instincts. It is also possible that the attorney general, who worked full time, felt less caseload pressure than did the part-time county prosecutors who handled liquor prosecutions-an issue I will take up more fully in Part II. But such arguments suggest only that charge bargains in capital cases should have been comparatively rare, whereas my research has turned up none before $1841 .^{104}$

102. See, e.g., Alschuler, supra note 2, at 5-16, 19-24.

103. See supra notes 21-27 and accompanying text.

104. At least two scholars have reported earlier Massachusetis cases that at first appear to have involved capital charge bargains. I do not believe, however, that any of the five cases cited in fact charged a capital offense, and in four of the cases, I am certain that there was no charge bargain. Adam Hirsch points to a series of "burglary" cases that came before the Supreme Judicial Court in 1784 and 1785, in which. he writes, "defendants pleaded innocent, and subsequently entered amended guilty pleas." ADAM JAY HIRSCH, THE RISE OF THE PENITENTIARY: PRISONS AND PUNISHMENT IN EARLY AMERICA 164 n.77 (1992). These four cases, however, all involved breaking and entering a shop or warehouse rather than a home. See Commonwealth v. Nero Fanueil, Sup. Jud. Ct. R. Book 75 (Feb. 1785) (charging a shop break); Commonwealth v. James Daken, Sup. Jud. CL. R. Book 67 (Feb. 1785) (warchouse break); Commonwealth v. Elijah Austin Smith, Sup. Jud. Ct. R. Book 263 (Scpt. 1784) (shop break); Commonwealth v. Thomas Joyce, Sup. Jud. Ct. R. Book 231 (Aug. 1784) (shop break). I believe that the use of the word "burglariously" in the charging language in each of these cases indicated not that these cases involved "burglary," but only that they involved nightime breaks. In any event, as the burglary statutes Hirsch cites make clear, capital burglary was restricted to home invasions. See Act of Apr. 26, 1770, ch. 16, §§ 2-3, 5 Mass. Prov. Acts 43, $43-44$ (expanding the circumstances in which the invasion of a "dwelling-house" shall be deemed a capital offense); Act of May 25, 1715, 1 Geo. 2, at 253 (Mass.) (defining capital burglary as a nighttime break into an inhabited "Dwelling House"). In each of the cited cases except Daken, at least one codefendant retracted an initial not-guilty plea, pled guilty to the crime charged, and was sentenced accordingly - that is, non-capitally. (Daken and his co-defendant pled guilty initially.) Retracting an earlier not-guilty plea in this way was quite common-at least in the 19 th century-but such a 
A possible solution to the mystery lies in the peculiar procedural form of charge bargains in capital cases. In liquor cases, as consideration for the defendant's plea to one of several counts of an indictment, the prosecutor would nol pros the remaining counts. Murder cases, in contrast, generally involved but a single offense, so there was no option to nol pros whole counts of the indictment. Moreover, as any one count charging murder was enough to assure the defendant's execution, nol prossing selected counts would create no incentive for a plea. Instead, the prosecutor's consideration for the defendant's plea took the form of a partial nol pros that effectively reduced the charge. In Train's 1848 murder case, for example, after the defendant pled guilty to manslaughter, Train said "he will no further prosecute this indictment as to the malice aforethought, and the charge of murder." 105 Similarly, in his 1841 rape case, Attorney General Austin responded to the defendant's plea of guilty of assault with intent to rape by "certif[ying] ... that he will prosecute on the other and further part of the indictment" - that is, so much of the indictment as charged rape-" no further." 106

Only three years earlier, in 1838, Austin had asked the Supreme Judicial Court to ratify his power to nol pros part of a single-count indictment. ${ }^{107}$ The court declared, "If the attorney general may enter a nolle prosequi as to the whole of an indictment, or of a count, so he may do it as to any distinct and substantive part of it." 108 Although the court maintained that earlier cases, "if they are law, are decisive of" the legality of partial nol prosses, ${ }^{109}$ those earlier cases gave only shaky authority for the practice. In two of the three cases cited by the court, both from 1805, the Supreme Judicial Court itself had recommended that the prosecutor enter a partial nol pros to eliminate a possibly defective part of the indictment. ${ }^{110}$ Capital

plea did not manifest a charge bargain (involving a reduction in the charged offense) and perhaps represented no understood bargain at all. See infra note 157.

David Flaherty reports an apparent charge bargain from 1749 in which the acting attorney general nol prossed so much of the indictment as charged "burglary." See David H. Flaherty. Criminal Practice in Provincial Massachusetts, in LAW IN COLONIAL MASSACHUSETTS 16301800, at 191, 220 \& n.9 (1984); see also Alschuler, supra note 2, at 17-18 (elaborating on Flaherty's find). But again, the case in question involved the breaking not of a home, but of a ship. See Commonwealth v. John Patterson, Super. Ct. Adjudicature R. Book 224 (1747-1750). Although it was not capital, the case does appear to have involved a charge bargain. The acting attorney general nol prossed the "Burglary therein charged, [and the defendants] pleaded guilty of the stealing therein charged." Id. Flaherty reports that "this episode is the only concrete evidence found on plea bargaining" in his research into criminal practice in colonial Massachusctts. Flaherty, supra, at 220.

105. Commonwealth v. Barney Goulding, Sup. Jud. Ct. R. Book 228 (Middlesex, Oct. 1848).

106. Commonwealth v. Michael Larry, Sup. Jud. Ct. R. Book 363 (Suffolk, Nov. 1841).

107. See Commonwealth v. Tuck, 37 Mass. (20 Pick.) 356, 356-57, 359 (1838).

108. Id. at 366.

109. Id.

110. See Commonwealth v. M'Monagle, 1 Mass. (1 Will.) 517 (1805); Commonwealth v. Lewis, 1 Mass. (1 Will.) 517 (1805). Only a year later, the court's chief justice wrote that courts should make no recommendations whatever on the use of nol prosses. See Commonwealth $v$. 
charge bargains, in contrast, involved the attorney general's independent use of a partial nol pros. Moreover, these two cases did not consider the legality of the partial nol pros, as the defendants apparently contested only the sufficiency of the indictment.

The third case, from 1828, provided useful dictum on the question of partial nol prosses, but no law. The court wrote that in the usual case, entering a partial nol pros, at least after conviction, "could be of no prejudice to the defendant." "II The court ruled, however, that entering a partial nol pros in the particular circumstances of that case was unfair to the defendant and therefore granted him a new trial. ${ }^{112}$ Only in 1838 , then, did the Supreme Judicial Court for the first time uphold the attorney general's unilateral power to nol pros part of an indictment. ${ }^{113}$ It is true that a later treatise writer would cite the 1828 case as authority for the prosecutor's power to enter a partial nol pros, ${ }^{114}$ but the Supreme Judicial Court itself, in later years, appears always to have relied on the 1838 case, though it sometimes cited one of the earlier cases as well. ${ }^{11}$ After securing this affirmation of his powers in 1838, Austin put it to use in carrying out capital charge bargains as early as 1841 . There is therefore no sharp disjunction between the early history of charge bargaining in liquor cases and its early history in capital cases. In both contexts, charge bargaining appeared almost as soon as a public prosecutor found he had the power to accomplish it.

The second puzzling moment in the chronology of capital charge bargains-the sudden surge of the 1860 s-also finds at least partial explanation in the prosecutor's expanding bundle of charging powers. In 1858 , the legislature separated the crime of murder into first and second degrees, ${ }^{116}$ abruptly granting prosecutors more precise control over

Wheeler, 2 Mass. (1 Tyng) 172, 174 (1806) (Parsons, C.J.) (“Certainly, the court are not legally competent to give any advice on this subject. The power of entering a nolle prosequi is to be exercised at the discretion of the attorney who prosecutes for the govemment, and for its excreise he alone is responsible.").

111. Commonwealth v. Briggs, 24 Mass. (7 Pick.) 177, 179 (1828).

112. See id. at 179-80. The prosecutor had sought, after trial, to nol pros so much of the indictment as charged that the defendant was a repeat offender. The court feared that the defendant had been prejudiced by the jury's knowledge of his former conviction.

113. It is not a foregone conclusion that the court should have approved partial nol prosses. They apparently were disallowed in New York. See People v. Porter, 4 Park. 524, 526 (N.Y. Oyer \& Terminer 1860) (reporting the opinion of a single judge of a court of oyer and terminer that. "[a]s I have before said, a nolle prosequi may be to the whole indicument, or to the whole of any one or more of several counts, but cannot be to a part of any one count").

114. See Emory WashbuRn, A MaNual of Criminal Law 205 n.4 (3d cd. 1900).

115. See Commonwealth v. Wakelin, 230 Mass. 567, 572 (1918) (citing the 1838 case and none earlier); Commonwealth v. Uhrig, 167 Mass. 420,423 (1897) (citing only the 1838 case); Commonwealth v. Wallace, 108 Mass. 12, 13 (1871) (citing both the 1838 case and the 1828 case); Commonwealth v. Jennings, 105 Mass. 586, 588 (1870) (citing both the 1838 case and one of the 1805 cases).

116. See Act of Mar. 27, 1858, ch. 154, 1858 Mass. Acts 126. The new law defined firstdegree murder as murder committed with premeditation, with extreme atrocity or cruelty, or while 
sentencing and more versatility in charge bargaining. Until 1858, plea bargains in murder cases could take only one form: the prosecutor's agreement to reduce the charge to manslaughter in exchange for the defendant's guilty plea. Unlike the nice calibration of sentences that prosecutors could manipulate in liquor cases through multiple charging and selective nol prossing, the penalty scheme in murder was a clumsy tool in their hands. By reducing the charge from murder to manslaughter, the prosecutor could spare the defendant the mandatory death penalty assigned to murder and guarantee him instead a prison term of from zero to twenty years. This measure of sentencing power is what permitted any charge bargaining at all in murder cases before 1858 . The prosecutor could not dictate, however, where within this wide-open range the judge would set sentence. No doubt many conscientious prosecutors shunned such deals because the defendant's crime, although perhaps not warranting death, deserved far more than the two years given Barney Goulding for killing his wife.

The legislature's separation of murder into degrees helped to allay such qualms. After 1858, in exchange for the defendant's guilty plea, a prosecutor could agree to reduce a first-degree murder charge that carried mandatory death to a second-degree charge that carried mandatory life in prison. ${ }^{117}$ The attorney general struck the first two such deals in $1863,{ }^{118}$ and six others followed before the end of the decade. Together they accounted for just under one-third of all plea bargains in murder cases in the 1860s. Although these second-degree deals cannot by themselves account for the striking increase in plea-bargained murder cases in the 1860 s, they surely contributed to the rise. Later, I will return to this story of charge bargaining in capital cases to consider other reasons for the sharp rise in the $1860 \mathrm{~s}$. Guilty pleas to second-degree murder proved throughout the rest of the century to be a critical part of the prosecutor's arsenal, consistently outnumbering guilty pleas to manslaughter as a means to resolve murder cases. ${ }^{119}$

Despite the gulf that would seem to divide a liquor-law violation that carried a mandatory $\$ 100$ fine from a murder that carried mandatory death, these two crimes share a common subplot in the story of plea bargaining's

committing or attempting to commit a life felony. Second-degree murder was all other murder. See id. $\S \S 1-2$.

117. See id.

118. See Commonwealth v. Edward Owens, listed in Report of the Attorney General for the Year Ending December 31, 1863, PUB. DOC. No. 17, at 7 (Mass. 1864); Commonwealth v. Thomas Coyne, listed in PUB. DOC. NO. 17, at 7.

119. In the $1860 \mathrm{~s}$, guilty pleas to second-degree murder accounted for $32 \%$ of all plea bargains in murder cases, while pleas to manslaughter still made up the majority- $68 \%$. In the $1870 \mathrm{~s}, 1880 \mathrm{~s}$, and $1890 \mathrm{~s}$, pleas to second-degree murder accounted for a steady $61 \%$ of all murder deals and manslaughter pleas for the balance of $39 \%$. These figures are gathered from the attorney general's reports of the relevant years studied. 
rise. In each case, the legislature's assignment of a mandatory minimum penalty-almost unique in the Massachusetts criminal universe-gave prosecutors the power to charge bargain. By using their nol pros power to reduce either the number of charges (in liquor cases) or the seriousness of the charge (in murder cases), prosecutors could promise defendants a clear and certain concession in exchange for their guilty pleas: Liquor defendants could save money, and accused murderers could save their lives. It is no wonder, then, that liquor and murder cases together accounted for the great majority of the clear plea bargains that took place in Massachusetts courts in the first two-thirds of the nineteenth century. The source of prosecutors' power to charge bargain in these cases is clear. It is time now to ask why they wanted to use it.

\section{THE PROSECUTOR'S Motives IN Plea BARgAINING}

\section{A. Why Plea Bargain at All? The Role of Caseload Pressure}

Asahel Huntington already has told us one answer. Prosecutors took up plea bargaining in part to escape the enormous burdens of their office. Huntington spoke from experience, for as Figure 2 shows, an unprecedented wave of cases began crashing upon him during his unlucky tenure. I noted earlier that the caseload jumped dramatically between the last years of Stearns's tenure and the beginning of Huntington's. After a lull of only forty-two cases in 1839, Huntington's caseload bounced back to 101 in 1843. In the next six years-as Huntington rounded out his years in office, Nelson came and went, and Train entered the scene-the caseload leapt to $443 .{ }^{120}$ Although the trend turned upward again toward the end of the century, the Middlesex district attorney never again in our time frame encountered a caseload calamity of this magnitude. Across the Charles River in Boston, the Suffolk County prosecutor faced a similar shock to the system. ${ }^{121}$

120. This figure represents all cases that came before the Court of Common Pleas in 1849. including those that were listed in merely summary fashion in the record books. Regarding this class of cases, see supra note 44; and infra notes 292-298 and accompanying text.

121. See THEODORE FERDINAND, BoSTON's LOWER CRIMINAL COURTS, 1814-1850, at 138 fig.5.1 (1992) (showing the rising caseload in Boston's municipal court. the counterpan to the Court of Common Pleas, beginning in the mid-1830s and tuming more stecply upward in the 1840s). In 1844, the Suffolk County district attomey repored 750 cases for the previous year. See S. DoC. No. 68, at 6 (Mass. 1844) (petition of Samuel D. Parker). In 1849, the Suffolk County district attorney reported 1672 cases for 1848. See H. DoC. No. 63, at 4 (Mass. 1849). 
Figure 2. CRIMINAL CASELOAD:

\section{MIDDLESEX COUNTY SUPERIOR COURT AND ITS PREDECESSOR COURTS}

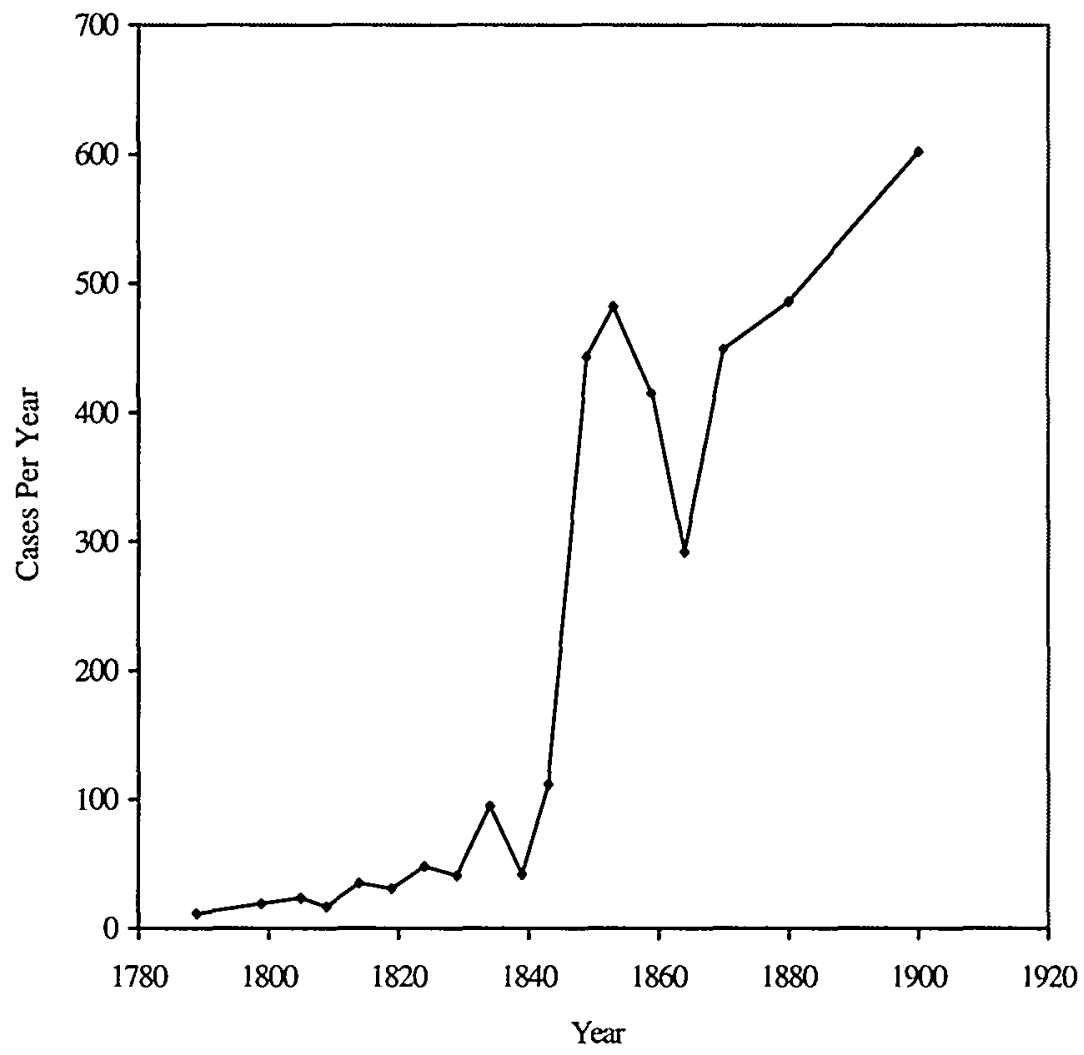

In part, no doubt, the caseload boom of the 1840s owed something to the sheer growth of crime that came with an exploding population. ${ }^{122}$ Perhaps-though this is not clear-improved policing produced more arrests, ${ }^{123}$ but in any event, more energetic enforcement does seem to have produced more liquor prosecutions. ${ }^{124}$ The legislature caused a good deal of

122. In 1844, the district attorney of Suffolk County (Boston) complained to the legislature that the county's "criminal business ... has kept equal pace with the increased population of the city." S. DOC. NO. 68, at 6 (petition of Samuel D. Parker). The population of Boston more than doubled between 1820 and 1845 to about 99,000. See OSCAR HANDLIN, BOSTON'S IMMIGRANTS 239 tbl.xiv (1959). Population growth alone, however, cannot account for the increased caseload. Michael Stephen Hindus reports that the rate of criminal prosecutions in Massachusetts grew from 169 per 100,000 in 1831-1840 to 277 per 100,000 in 1841-1850. See HiNDus, supra note 10, at 77.

123. We are more likely to see such an impact in Boston, where the legislature authorized the creation of a police force in 1838, see Act of Apr. 17, 1838, ch. 123, 1838 Mass. Acts 421, than in the rest of the state, where the legislature did not grant similar authority until 1851, see Act of May 15, 1851, ch. 162, 1851 Mass. Acts 657.

124. See FERDINAND, supra note 121 , at 14 ("The Commonwealth made a concerted effort 10 limit the sale of spirits in the late 1830 s and 1840 s through licensing, and liquor violations grew 
the caseload increase with its decision in 1832 to extend the jurisdiction of the Court of Common Pleas to all noncapital crimes, many of which the Supreme Judicial Court formerly had heard. ${ }^{125}$ And the caseload grew because more defendants exercised their right to appeal from lower tribunals to the Court of Common Pleas ${ }^{126}$ - perhaps in part a result of more defendants' having lawyers. ${ }^{127}$

by leaps and bounds."); HAMPEl, supra note 65 , at 152 ("In each one of the seven years from 1845 to 1851 , [liquor] license cases made up between $30 \%$ and $40 \%$ of the business of the [Massachusetts] courts."). It is possible that part of the increase in liquor cases is due to a shift of cases from the lower police courts. Theodore Ferdinand saw such a shift in his study of Boston's courts. See FERDINAND, supra note 121, at 84 tbl.3.9.

125. The 1832 jurisdictional shifi slashed the criminal workload of the Supreme Judieial Court sitting in Middlesex County to nearly nothing:

Middlesex County Criminal Caseload:

COURT OF COMMON PLEAS AND SUPREME JUDICLAL COURT

\begin{tabular}{|c|c|c|}
\hline & \multicolumn{2}{|c|}{ NUMBER OF CASES } \\
YEAR & COURT OF COMMON PLEAS & SUPREME JUDICLAL COURT \\
\hline 1799 & 17 & 12 \\
\hline 1809 & 14 & 24 \\
\hline 1819 & 24 & 30 \\
\hline 1824 & 48 & 36 \\
\hline 1829 & 41 & 20 \\
\hline 1834 & 95 & 7 \\
\hline 1839 & 42 & 1 \\
\hline 1843 & 101 & 0 \\
\hline 1849 & 443 & 4 \\
\hline
\end{tabular}

Sources: Middlesex Ct. Gen. Sess. Peace R. Books; Sup. Jud. C. R. Books (Middlesex sittings) (on file with the Massachusetts Archives).

126. The caseload was as follows:

APPEALS FROM LOWER TRIBUNALS:

MIDDLESEX COURT OF COMMON PLEAS AND ITS PREDECESSOR COURT

\begin{tabular}{|c|c|c|c|}
\hline YEAR & $\begin{array}{c}\text { NUMBER OF } \\
\text { CASES }\end{array}$ & NUMBER OF APPEALS & $\begin{array}{c}\text { APPEALS AS \% OF } \\
\text { TOTAL }\end{array}$ \\
\hline $1789-1790^{*}$ & 23 & 0 & 0 \\
\hline $1799-1800^{*}$ & 38 & 2 & 5 \\
\hline $1805-1806^{*}$ & 47 & 3 & 6 \\
\hline $1809-1810^{*}$ & 34 & 1 & 3 \\
\hline $1814-1815^{*}$ & 70 & 5 & 7 \\
\hline $1819-1820^{*}$ & 62 & 2 & 3 \\
\hline 1824 & 48 & 2 & 4 \\
\hline 1829 & 41 & 3 & 7 \\
\hline 1834 & 95 & 1 & 1 \\
\hline 1839 & 42 & 1 & 2 \\
\hline $1843-1844^{*}$ & 224 & 12 & 5 \\
\hline 1849 & 443 & 134 & 30 \\
\hline
\end{tabular}

* Two-year totals

Sources: Middlesex Ct C.P. R. Books; Middlesex Ct. Gen. Sess. Peace R. Books; Sup.

Jud. Ct. R. Books (Middlesex sittings) (on file with the Massachusetts Archives).

127. I will argue in Part IV that the proportion of defendants who had lawyers probably increased in the early part of the century. See infro notes $435-440$ and accompanying text. It is clear that defendants with lawyers accounted for the great majority of cases appealed to the Court of Common Pleas from lower tribunals-73\% of them in 1849 , although only $60 \%$ of all 
Daunting as it surely was, the spiking caseload depicted in Figure 2 does not fully capture the pressures Huntington and his successors faced. The graph does not reflect the addition of Essex County to the district attorney's duties between 1832 and $1848,{ }^{128}$ or the absence of an attorney general during the legislature's unwise experiment with austerity between 1843 and 1849 , which shifted responsibility for prosecution of the most serious cases onto district attorneys' shoulders. ${ }^{129}$ All this Huntington and his successors handled with no apparent assistance, not even so much as a clerk to help draft their indictments. ${ }^{130}$ Little wonder that on leaving office in October 1845, Huntington resorted to nol prossing 252 Middlesex cases apparently to avoid saddling Albert Nelson with his backlog. ${ }^{131}$

Even before the caseload boom of the Huntington years, Massachusetts prosecutors had strong reason to embrace the efficient promise of plea bargaining. Like most public prosecutors in nineteenth-century America, they worked part-time, drew (at best) part-time salaries, and therefore held more than one job. Hence Samuel Dana, who claimed he earned no salary

defendants had lawyers in that year. See Middlesex Ct. C.P. R. Book (1849); Middlesex Ct. C.P. Docket Book (1849); infra note 436; cf. F.W. G[rinnell], Legislative Problems in Regard to the Administration of the Criminal Law and Legislative Progress During the Session of 1923, MASS. L.Q., May 1923, at 7, 9 (quoting a former Massachusetts assistant district attorney in the carly 1920 s as writing that "[i]n a large majority of appeal cases, defendants have counsel").

128. See Act of Feb. 16, 1848, ch. 16, 1848 Mass. Acts 605; Act of Mar. 14, 1832, ch. 130 , $\$ 9,1832$ Mass. Acts 396, 404-06 (enlarging the jurisdiction of the Court of Common Pleas in criminal cases and the duties of prosecuting officers). The Essex County caseload was smaller than that of Middlesex, but not by much. In 1842, for example, 126 criminal cases were addressed in the Middlesex Court of Common Pleas and 102 cases in Essex. See Middlesex Ct. C.P. R. Book (1842) (on file with the Massachusetts Archives); Essex Ct. C.P. R. Book (1842) (on file with the Essex County Superior Court). 844:

29. Suffolk County District Attorney Samuel D. Parker complained to the legislature in

The office of Attorney General has been abolished;-capital trials in [my] county have been added to [my] department, as well as the task of arguing all questions of law in the Supreme Judicial Court, in which the Commonwealth is a party, formerly the exclusive duty of the Attorney General.

S. DoC. No. 68, at 6 (Mass. 1844) (petition of Samuel D. Parker); see also id. at 7, 8 (statement of J.H. Clifford, Jan. 20, 1843) (reprinting the complaint of the district attorney for the Southern District that by eliminating the attomey general's office, the legislature had "largely increased" the labors of the district attorneys); LOWELL COURIER, July 15, 1845, at 2 (reprinting an item from the Salem Register complaining that abolishing the office of the attorney general was "nothing less than wanton cruelty" to the district attorneys).

130. I have seen no reference to an assistant prosecutor anywhere in Massachusetts before 1852, when one was appointed by the Boston Municipal Court. See FERdinand, supra note 121, at 191. In 1875, the legislature provided for a part-time assistant district attorney for the Northern District (Middlesex) and others. See Act of Feb. 11, 1875, ch. 12, 1875 Mass. Acts 602, 602. An 1873 law permitted appointment of a clerk to assist district attomeys. See Act of May 12, 1873. ch. 278, 1873 Mass. Acts 707, 707.

131. See Middlesex Ct. C.P. R. Book 147-50 (Oct. 1845). Nelson, Huntington's successor, fared little better. At the end of the next year, he nol prossed 229 cases, and as he prepared to leave office at the end of 1847 , he nol prossed another 182. See Middlesex Ct. C.P. R. Book 323 (Feb. 1848) (indicating the first appearance of Nelson's successor, Charles Russcll Train); Middlesex Ct. C.P. R. Book 299-300 (Oct. 1847); Middlesex Ct. C.P. R. Book 223-29 (Oct. 1846). 
at all as county attorney, ${ }^{132}$ also served as president of the Massachusetts Senate during the first two years of his tenure. ${ }^{133}$ Asahel Stearns not only served in Congress while he was district attorney, he also spent twelve years as the founding and sole full-time professor of the Harvard Law School. ${ }^{134}$ Prosecutors with less exalted second jobs felt even more pressure to resolve their criminal cases quickly: Most supplemented their incomes with a civil law practice, ${ }^{135}$ and because the Court of Common Pleas heard civil and criminal cases at the same session, these lawyers could do no civil business until their criminal work was done. Many district attorneys therefore rushed through their criminal cases to get on with the business of making money, as one explained to the legislature in 1844:

The call for my attendance upon the grand jury, occasions a very frequent interference with my engagements in civil cases, and a consequent pecuniary loss to myself... . The practice to which [Samuel D. Parker, district attorney of Suffolk County,] alludes, of making extra exertions in order to dispatch the business before the grand-jury, is, I believe, common to all the prosecuting officers. I endeavor, if possible, to have the grand jury dismissed on the

132. See REPORT OF THE DANA COMMTTEE, supra note 15, at 4.

133. See DAvis, supra note 7, at 219-20. In his response to Iegislative charges of malfeasance in 1809, Dana mentioned that he had been "engaged at the Legislature" during the June 1808 sitting of the Court of Common Pleas. REPORT OF THE DANA COMAITTEE, supra note 15, at 5.

134. Stearns was county attorney of Middlesex between about 1809 and 1832. See supra notes 19,56 and accompanying text. He served in Congress from 1815 to 1817 and as principal professor at Harvard Law School from 1817 to 1829. See I DAVIS, supra note 14, at S61. Isaac Parker, chief justice of the Supreme Judicial Cour, served as the Royall Professor of Law at Harvard, but

[f]or the twelve years of his incumbency, Judge Parker had no closer direct connection with the Law School than was afforded by the attendance of the students at his lectures and a vague understanding that he was occasionally to visit the school and examine the men. The working member of the faculty was Asahel Stearns.

Frank W. Grinnell, Couns and Lawyers in Metropolitan Boston, in 1 METROPOLITAN BOSTON: A MODERN HISTORY 243, 263 (Albert P. Langtry ed., 1929). In 1826. Stearns reported on the burdens of his professorship to the college president:

A large portion of the Professor's time is employed in selecting and preparing suitable questions and cases for argument at the moot cour, and in assisting the students to put them into this form of judicious action, examining their declarations, pleas, replications, demurrers, bills of exceptions, motions, etc., and directing them in the course of their investigations and researches. But of the amount of time thus employed, and of that also which is devoted to answering the numerous questions, and solving the doubts which occur to the students, (and which they are encouraged and desined to suggest with freedom when they occur), it is impossible to make any correct estimate. 1 WARREN, supra note 56, at 357 (quoting Stearns).

135. John H. Clifford, who was district attorney of the Southem District during the 1840s, was said to have maintained "the leading civil practice on the circuit." John $\mathrm{H}$. Clifford Papers. Box 1845-1851, Jan.-Oct. 1850 Folder (on file with the Massachusetts Historical Society). This claim appears in a handwritten biography or autobiography of Clifford kept among his papers.

It is likely that most American prosecutors supplemented their incomes with civil practices. See, e.g., LAWRENCE M. FRIEDMAN \& ROBERT V. PERCIVAL, THE ROOTS OF JUSTICE: CRIME AND PUNISHMENT IN ALAMEDA COUNTY, CALIFORNLA 1870-1910, at S0-51 (1981) (reporting that Alameda County prosecutors of the late 19th century had civil practices on the side). 
morning of the second day, and I generally succeed. To accomplish this, it is often necessary to continue the sessions of the grand jury until late in the evening, and the night is mostly spent in drawing indictments. I know of no combination of bodily and mental labor equal to that to which the prosecuting officers subject themselves on such occasions. ${ }^{136}$

The pressure to plea bargain was therefore part and parcel of part-time prosecuting: No matter how many criminal cases a district attorney had, he could make more money by handling them with dispatch. ${ }^{137}$

Still, the incentive to get through one's cases grew particularly intense in the 1840 s as caseloads leapt higher. In 1843 , by the same stroke with which the legislature wiped out the office of the attorney general, it salted prosecutorial wounds with a thirty-percent pay cut. ${ }^{138}$ The result was a storm of protest from prosecutors and their supporters, who deluged the legislature with accounts of their overwork. One district attorney calculated that his new $\$ 700$ salary worked out to eighty-eight cents a case. ${ }^{139}$ Another detailed the burdens of following the court on circuit within his district:

I reside in Greenfield. I have to travel twenty miles to attend the courts at Northampton, forty miles to go to Springfield, and something more than fifty miles by the most direct rout[e] to reach

136. S. DoC. No. 68, at 10, 12 (Mass. 1844) (reprinting the letter of Daniel Wells, district attomey of the Western District). Wells suggested that he "could afford to do the duties of the office for a less compensation, if the business of the court admitted of the establishment of separate criminal terms." Id. at 12 . Whether for this reason or others, the various counties in fact moved toward separate criminal and civil sessions, a step Middlesex County took in 1839 . See Middlesex Ct. C.P. R. Book (1839) (on file with the Massachusetts Archives) (recording June 1839 as the first Middlesex sitting of the Court of Common Pleas that held separate civil and criminal sessions). In other counties, the change came later. See H. DoC. No. 63, at 15 (Mass. 1849) (reporting the complaint of the district attomey for the Eastern District about the "urgent necessity for the separation of the criminal from the civil business of the Court of Common Pleas ... as in some of the other large districts of the Commonwealth").

137. The same dynamic was at work in New York. See JOHN STANTON Gould ET AL., TWENTY-FIRST ANNUAL REPORT OF THE PRISON ASSOCIATION OF NEW YORK (1866), reprinted in N.Y. ASSEMBLY DOC. NO. 50, at 149 (1866) ("[W]here the district attorney has private practice in the court, for which he is paid, it is natural that he should attend to that in preference to the criminal business for which he is not paid otherwise than by salary."). Albert Alschuler reports that this dynamic was still at work in the 1960 s, when he discovered to his surprise that part-time prosecutors in a downstate Illinois county plea bargained a larger proportion of their cases than did full-time prosecutors in Chicago. See Albert W. Alschuler. The Prosecutor's Role in Plea Bargaining, 36 U. CHI. L. REV. 50, 59 n.31 (1968).

138. See Act of Mar. 7, 1843, ch. 9, 1843 Mass. Acts 6, 6. This act reduced the salaries of most of the district attomeys from $\$ 1000$ to $\$ 700$ a year. The salary of the Suffolk County district attorney, whose position was nearer to full-time, was cut from $\$ 1800$ to $\$ 1500$. Associate justices of the Court of Common Pleas eamed $\$ 1800$ during most of the first half of the century, see Act of Feb 14, 1821, ch. 79, $\S 10,1821$ Mass. Acts 545, 551, though the legislature also reduced their salaries in 1843 to $\$ 1700$, see $\$ 1,1843$ Mass. Acts at 6. "[I]ndustrious laboring men" earned $\$ 300$ in the 1830 s. Moderate Drinking a Losing Business, LowELL COURIER, Nov. 29. 1836, at 1 .

139. See S. DoC. No. 68, at 7, 9 (memorial of J.H. Clifford). By contrast, the Suffolk County district attorney was well paid at two dollars a case. See id. at 6 (petition of Samuel D. Parker). 
Lenox. There is no rail-road communication except in passing from Springfield to Pittsfield. As the public means of communication between Greenfield and Lenox are very inconvenient, and the season when the courts are held often renders it hazardous to travel with a private conveyance, I frequently go and return by the way of Springfield - which makes the distance travelled about one hundred miles. ${ }^{140}$

A third sounded themes from Dickens:

$[U]$ nremitted professional labors, night and day, with no vacation and no assistance, and perpetual confinement daily and all day, in badly ventilated court-rooms, will break down the best constitution .... If [relief] cannot be obtained, I must retire from an office too onerous to be borne by one unassisted individual. ${ }^{141}$

As for Huntington, a Middlesex County newspaper said his "inadequate and niggardly" salary was sad thanks for his "fidelity to his arduous duties," 142 and a Middlesex legislator told his colleagues that if they "[p]ut the case of Attorney Huntington to the people of Middlesex county, ... nine-tenths of the people would say that he should have at least \$1000 a year salary." 143 Admitting its errors, the legislature restored district attorneys' salaries in $1845^{144}$ and in 1849 reinstated the office of attomey general. ${ }^{145}$

Perhaps from pure necessity, and perhaps from necessity tinged with pique at the legislature's offenses, prosecutors appear to have accelerated their plea-bargaining practices in the 1840s. That is when the pattern of multiple charging that Huntington built upon his preprinted forms first drew the legislature's attention and when Albert Nelson boldly put abroad the terms by which he would deal. It is when Charles Russell Train, who felt the full force of the caseload wave, began to plea bargain his liquor cases with unprecedented frequency. And it is when Train and two other pioneering prosecutors first struck plea bargains in capital cases.

140. Id. at 10, 11 (letter of Daniel Wells).

141. H. DOC. No. 63, at 4, 5 (Mass. 1849) (abstracting from the report of Samuel D. Parker, the county attorney for Suffolk County). Theodore Ferdinand reports that Parker's caseload grew from 228 cases in 1830 to 1532 in 1850 . See FERDINAND, supra note 121, at 67.

142. Letters from the Editor.-No. 6, LOWEL I COURIER. Jan. 14, 1845, at 2.

143. Massachusetts Legislature, LOWELL COURIER, Jan. 21, 1845, at 2.

144. See Act of Feb. 10, 1845, ch. 36, 1845 Mass. Acts 412,412 (establishing the salary of the district attorney for the Northem District of the Commonwealth): Act of Jan. 29. 1845. ch. 14. 1845 Mass. Acts 401, 401 (establishing the salary of the district attomey for the Southem District). By restoring the district attomeys' salaries to $\$ 1000$, the legislature by no means squelched prosecutorial discontent or editorial criticism. In 1847, as Albert Nelson prepared to leave office apparently because of his low salary, another local paper called the legislanure "niggardly." Mr. Attomey Nelson, LOWEL J., Oct. 1, 1847. at 2.

145. See Act of May 1, 1849, ch. 186, 1849 Mass. Acts 117, 117. 
I do not mean to argue that caseload pressure is sufficient for prosecutors to engage in plea bargaining. On the contrary, without the power to make meaningful concessions to defendants, prosecutors normally cannot induce them to plead. The nearly total lack of prosecutorial power to constrain the judge's sentencing discretion in non-liquor cases other than murder probably explains the almost complete absence of clear plea bargains in such cases during the first two-thirds of the nineteenth century. Nor is a big caseload a necessary condition of prosecutorial plea bargaining. Especially when prosecutors were part-time workers, as most American prosecutors were in this period, there was always some pecuniary incentive to reduce their criminal workload, however small it was. But as I believe the Middlesex experience of the 1840s helps to show, an increasing caseload obviously does increase pressure on prosecutors to plea bargain.

So I do not join the ranks of recent plea-bargaining scholars who reject "the myth of caseload pressure" told and retold by scholars of the generation before. ${ }^{146}$ Two of the new generation of scholars, Mary Vogel and Theodore Ferdinand, have based their research in Boston courts in the nineteenth century, and their arguments against the influence of caseload pressure therefore seem directly contrary to my own analysis. I will consider their work in some depth, both on this narrow question of caseload pressure and, in a few pages, on the larger question of the impulses behind plea bargaining's rise.

Mary Vogel titles a section of her earliest work on the emergence of plea bargaining in Boston, "The Myth of Caseload Pressure." ${ }^{447}$ Yet her evidence of caseload pressure and guilty-plea rates in fact supports a conclusion that the two are strongly and causally related. ${ }^{148}$ Vogel's contrary belief that caseload was unimportant to the growth of plea bargaining arises not from her evidence, which shows caseload and guilty pleas rising roughly in tandem, but only from her way of charting these trends. I have reproduced in Figure 3 Vogel's diagram plotting the increase

146. Mary Elizabeth Vogel, Courts of Trade: Social Conflict and the Emergence of Plen Bargaining in Boston, Massachusetts, 1830-1890, at 163 (1988) (unpublished Ph.D. dissertation, Harvard University) (on file with the Stanford Law School Library; Univ. of Mich. Microfilmed Dissertations); see also Milton Heumann, A Note on Plea Bargaining and Case Pressure. $9 \mathrm{~L}$. \& SOC'Y REV. 515, 516-17 (1975) (surveying studies that say caseload pressure played a large role in bringing about plea bargaining's rise).

147. Vogel, supra note 146, at 163.

148. Vogel conducted her research in the Boston Police Court. See Mary E. Vogel. The Social Origins of Plea Bargaining: Conflict and the Law in the Process of State Formation, 18301860, 33 L. \& SOC'Y REV. 161, 176 (1999) (identifying the Boston Police Court as the source of data on guilty-plea rates through 1866). The records of the police court apparently did not reveal clear plea bargains, in which the exchange of plea for concession was apparent on the face of the records. Vogel therefore engages in an elaborate examination of the pattern of concessions across cases over time. See id. at 180-95. But as this procedure permitted her to draw no firm conclusion about whether any particular case was a plea bargain or a simple guilty plea, her numerical comparison of caseload and plea bargaining had to rely on guilty-plea rates. See id. at 219. 
of guilty-plea rates and caseload between 1830 and $1920 .^{1.9}$ On the basis of this diagram, Vogel concludes that "the surge of guilty pleas, which heralded the rise of plea bargaining during the 1830s, 1840s, and 1850s, preceded rather than followed the marked increase in caseload seen after the 1840s"-suggesting that caseload pressure could not have brought on the rise of plea bargaining. ${ }^{150}$ But the chronological ordering of the two trends is an unintended illusion of the graph's design. The graph plots both trends-caseload and guilty-plea rate-in terms of percentage increases over the year before. Both lines therefore start at zero in 1830 and climb promptly upward. Between 1830 and 1840 , the guilty-plea line rises rather sharply (perhaps because the guilty-plea rate genuinely began near zero ${ }^{151}$ ), while the caseload line rises modestly. This incongruence, if we should call it that, shifts the line representing caseload to the right and makes it look chronologically behind the guilty-plea line. In fact, during the next period, 1840 to 1850 , both lines rise sharply in nearly equal measure and then, between 1850 and 1860 , both lines rise modestly in roughly equal measure.

Between 1860 and 1870, the caseload line takes a dramatic leap upward, while the guilty-plea rate rises only modestly. But here we encounter another illusion of the graph's design: The graph compares caseload with the guilty-plea rate. ${ }^{152}$ That is, guilty pleas are expressed as a percentage of all cases. Because caseload can (in theory) expand indefinitely whereas the guilty-plea rate cannot exceed $100 \%$, the increase of the guilty-plea rate simply cannot keep up with an exploding caseload. It appears that between 1860 and 1870 , caseload increased by a factor of two or three, ${ }^{153}$ while the guilty-plea rate increased from about forty-five percent to sixty or sixty-five percent. ${ }^{154}$ That is, both figures rose substantially, even if one rose more dramatically than the other. It is true that the two trends plotted on Vogel's diagram moved in opposite directions between 1870 and 1880 and between 1880 and 1890 , but these instances were both exceptional-occurring only twice in the nine time periods shown-and modest, in the sense that neither trend was moving sharply.

149. See id. at 220; Vogel, supra note 146, at 163-64.

150. Vogel, supra note 148, at 219; see also Vogel, supra note 146, at 163.

151. See Vogel, supra note 148, at 176; Vogel, supra note 146, at 59.

152. The graph is titled "Guilty plea rates and caseload pressure." Vogel. supra note 146, at 220.

153. See Vogel, supra note 148, at 220.

154. See id. at 176; Vogel, supra note 146. at 59. 
FIGURE 3. VOGEL'S DIAGRAM:

Guilty Plea Rates and CASEload PREssure

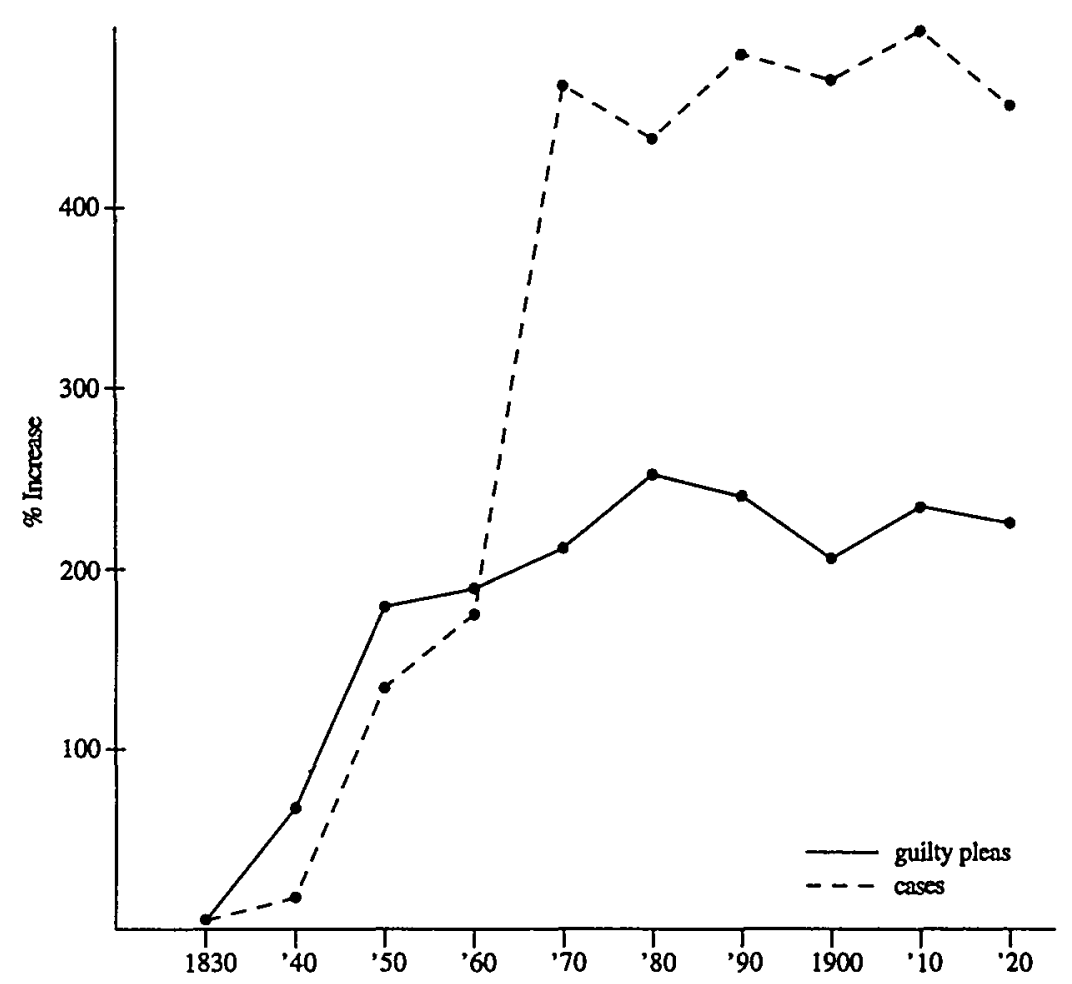

Like Vogel, Theodore Ferdinand produces better evidence of a link between caseload pressure and the rise of plea bargaining than he seems prepared to admit. His study of the Boston Municipal Court, a jury forum nearly identical in form and function to the Court of Common Pleas, ${ }^{155}$ shows that caseload held steady or even declined through the first third of the century. Caseload then turned sharply upward in 1836 and had more

155. Ferdinand also studied the Boston Police Court, a non-jury forum from which prosecutors generally were absent. See FERDINAND, supra note 121, at 50. As I will explain in more detail below, see infra notes 223-228 and accompanying text, I do not believe that the work of the police court can shed much light on the operations of a jury forum in which prosecutors conducted business for the state. With regard to the police court, Ferdinand sometimes endorses and sometimes dismisses a link between caseload pressure and plea bargaining's rise. Compare FERDINAND, supra note 121 , at 65 ("The Police Court initiated plea bargaining for the same reason that it was developed in the Municipal Court: to ease the burdens of prosecution."), with id. at 93 ("[T]here was no prosecutor in the Police Court, and little if any relationship between caseload and plea bargaining."). 
than tripled by $1844 .{ }^{156}$ Meanwhile, Ferdinand says, plea bargaining arose in the late 1830 s and early $1840 \mathrm{~s} .{ }^{157}$

Ferdinand then hesitates to link these two trends in a causal way: "Whether plea bargaining was a response to burgeoning caseloads," he says, "is debatable." 158 Yet the reason for his reticence seems wrong. Ferdinand concludes that plea bargaining in this era was "restricted to vice or regulatory" offenses ${ }^{159}$-two categories that either overlapped with the liquor law or had generally similar penalty schemes. ${ }^{160}$ He hesitates to link rising caseloads with rising numbers of guilty pleas because in vice and regulatory offenses, "the sharpest increases [in caseload] were experienced after plea bargaining took hold." 161 But Ferdinand's concem to match the rise of plea bargaining in vice and regulatory offenses with the rise in caseload in those same offenses mistakes the mechanism that linked caseload pressure with plea bargaining. Caseload pressure generally increased prosecutors' incentives to plea bargain. Once prosecutors felt a general incentive to lighten their workload, they struck plea bargains whenever they had the power to do so-that is, whenever rigid penalty schemes permitted them to manipulate sentences by manipulating charges. There is no reason to expect that the category of cases in which prosecutors found that power-a category I label liquor-law violations and Ferdinand labels vice and regulatory offenses-should happen also to be the category that grew the fastest. But of course, my argument that prosecutors under pressure naturally chose to plea bargain in liquor cases assumes an

156. See FERDINAND, supra note 121 , at 138 .

157. See id. at 81. Ferdinand reports that between 1832-1840 and 1842-1850, the proportion of municipal court cases ending in pleas of either guilty or no contest grew by more than halffrom $19.3 \%$ to $31.8 \%$. See id. at 100 tbl.4.1. Ferdinand prefers to consider those cases in which the defendant offered an initial plea of guilty or no contest separately from those in which the defendant initially pled not guilty and later changed her plea to guilty or no contest. See id. at 100 01 . In fact, if we focus on only the latter cases, then the 1840 s look like a true revolution in plea bargaining: Changed pleas surpassed $17 \%$ of all cases after the 1840s, although they never amounted to three percent before that decade. See id. The starkness of the increase does suggest that something significant took place, and Ferdinand may well be right that a retracted plea is a sign that prosecutor and defendant conferred after the initial plea and reached a deal. See id. at 7477,101 . The large increase in the number of changed pleas, however, also may have resulted from a change in record-keeping practices-that is, from a decision to record both pleas when only the final plea generally had been recorded before. Cf. Lynn M. Mather. Comunents on the History of Plea Bargaining, 13 L. \& SOC'Y REV. 281, $284-85$ (1979) (noting that an initial plea of guilty could result from an explicit charge bargain made before charges were finalized).

158. FERDINAND, supra note 121 , at 93.

159. Id. at 81 . Of the two categories, regulatory crimes showed the most striking increase in guilty-plea rates during the $1840 \mathrm{~s}$ and the highest overall incidence of guilty pleas-55.2\% between 1842 and 1850. See id. at 59 tbl.2.3. The guilty-plea rate in vice offenses never surpassed $35 \%$. See id.

160. See infra Appendix B (analyzing Ferdinand's calegory of "vice or regulatory" offenses).

161. FERDINAND, supra note 121 , at 93 . 
understanding about why plea bargaining arose first in liquor cases. I will turn to that issue now.

\section{B. Why Plea Bargain in Liquor Cases?}

Ferdinand and I agree that plea bargaining in Massachusetts first took root in cases involving alcohol, but we part ways at the underlying question of prosecutorial motives. Why did prosecutors choose liquor (and murder) cases as the medium in which to mold the future? I note murder cases in parentheses because Ferdinand and Vogel did not extend their research into the Supreme Judicial Court and so did not discover early evidence of charge bargaining in murder cases. The discussion that follows therefore refers primarily to liquor cases, though lessons learned in murder cases inevitably intrude.

I will begin by setting out my own explanation of plea bargaining's early emergence in liquor cases. That the liquor law's rigid penalty scheme gave prosecutors the power to bargain in such cases is of course part of the answer, but a full answer requires as well an explanation of plea bargaining's initial failure to spread to those cases in which judges held the balance of sentencing power. Therefore, I will consider why judges did not join forces with prosecutors in promoting plea bargaining's cause.

In Section C, I will take up Ferdinand's and Vogel's alternative explanations of the early rise of plea bargaining. I have chosen to give such close attention to Ferdinand's and Vogel's work in part because theirs appear to be the only other full-scale empirical analyses of plea bargaining's rise and in part because both worked in Boston. But the greater importance of their work to my study lies elsewhere. In rejecting the importance of caseload pressure as a motivation in plea bargaining's rise, as Vogel does entirely and Ferdinand does in a more hesitant way, each has declared in differing degrees an intention to move beyond an analysis staked in the personal interests of courtroom actors and to embrace a more complex vision of the plea-bargaining dynamic. Often-perhaps usuallytaking a broader focus improves the telling of history. I do not believe this is one of those times. The evidence overwhelmingly suggests that plea bargaining was the work of those who labored in the criminal courts and was the product of their personal interests and struggle for power. Though Ferdinand and particularly Vogel add richness and color to the story of plea bargaining's rise, and though I could with some ingenuity reconcile my telling with theirs, any gain in color would be a loss in accuracy.

My own explanation of plea bargaining's early dominance in liquor cases is therefore brief: Prosecutors plea bargained in liquor cases because they could. Among all of the most commonly prosecuted crimes, only in liquor cases did the statutory penalty scheme so tightly bind the judge's 
hands in sentencing that the prosecutor could, by manipulating charges, dictate the sentence. Not even in murder cases did the prosecutor have such complete sentencing power, for when a defendant pled guilty to manslaughter in the course of a prosecutorial charge bargain, the judge's sentencing discretion spanned a full twenty years.

The peculiar power that prosecutors held in liquor cases stands in sharp relief against the ineptitude they showed when attempting to charge bargain in non-liquor cases other than murder. In 1852, for reasons I will discuss shortly, Massachusetts prosecutors lost their power to charge bargain in liquor cases. The record books of the Court of Common Pleas for the next year show that Charles Russell Train handled 482 cases, but secured a clear plea bargain of the sort we have seen in liquor cases only once: In a twocount forgery indictment, district attorney Train nol prossed one count after the defendant pled guilty. ${ }^{162}$ When Isaac Morse succeeded Train in $1855,{ }^{163}$ he apparently resolved to find new territory in which to establish a chargebargaining regime. He settled on breaking-and-entering cases. Of thirtynine indictments Morse sought in $1859^{164}$ for either breaking and entering or theft from a building, he alleged separate counts for committing the crime by nighttime and by daytime in all but four of them. In contrast, in none of the fifty-two cases of this sort that Train had prosecuted in 1849 and 1853-the two years of his tenure that I studied-did he allege separate nighttime and daytime counts. ${ }^{165}$

Despite Morse's cleverness in positioning these cases for charge bargaining, only four of the thirty-nine ended in the sort of charge bargain that he apparently had in mind-with his nol prossing one of the two counts in exchange for the defendant's guilty plea to the other. ${ }^{166}$ It is not surprising that the tactic was so weak. The maximum penalty for breaking and entering in the nighttime was twenty years. For breaking and entering

162. See Commonwealth v. Henry Howard, Middlesex Ct. C.P. R. Book 193 (Oct. 1853).

163. See 1 DAVIS, supra note 14, at 389; DAVIS, supra note 7, at 289.

164. Two-thirds of the way through the 1859 coun year, the Superior Court supplanted the Court of Common Pleas. But for its new name and new roster of judges, the new coun looked very much like the old, and record-keeping practices continued virtually unchanged. See Act of Apr. 5, 1859, ch. 196, 1859 Mass. Acts 339, 339 (establishing the superior courts); Middlesex Ct. C.P. R. Book (1859) (on file with the Massachusetts Archives); HINDUS, supra note 10, al 17.

165. In my study of selected years' records of the first half of the century. I did not come across any breaking-and-entering or larceny-from-a-building case that charged separate counts for nighttime and daytime. In unsystematic browsing through other years, I came upon only one such case-in 1846. See Commonwealth v. Francis Smith, Middlesex Ct. C.P. Docket Book No. 274 (Oct. 1846).

166. Only one of the four deals ended the way one might expect-with the defendant's pleading guilty to the daytime count and the prosecutor's nol prossing the nightime count. See Commonwealth v. Harry Peterson, Middlesex Ct. C.P. R. Book 94 (Feb. 1859). The other three took the opposite form. See Commonwealth v. William C. Riley, Middlesex Cl. C.P. R. Book 209 (June 1859); Commonwealth v. John Petite, Middlesex C. C.P. R. Book 113 (Feb. 1859); Commonwealth v. Joseph Merrett, Middlesex Ct. C.P. R. Book 88 (Feb. 1859). 
in the daytime, it was five years. ${ }^{167}$ But the judge's sentence in the thirtyfive cases that ended in guilty findings ${ }^{168}$ exceeded five years only twice ${ }^{169}$ and never exceeded ten years. Because there was no minimum punishment assigned to either count and because judges were not much inclined to approach the maximum, Morse conferred little apparent benefit by nol prossing one count. ${ }^{170}$ In fact, as the defendant could not logically be guilty of both a nighttime and a daytime break, the jury usually convicted the defendant on only one count. When the jury did return a general verdict of guilty, Morse often nol prossed one of the two counts in any event. ${ }^{171}$ It is little wonder, then, that charge bargaining in breaking-and-entering cases worked only with unrepresented defendants. Although the defendant had counsel in thirteen of these thirty-nine cases, the four charge-bargained cases were not among them. ${ }^{172}$ Lacking the kind of control over the

167. See MASS. GEN. STAT. ch. $161, \S \S 11-12,14$ (William White 1860). The penalties were stiffer if the offender was armed or assaulted someone present in the building, see id. $\$ \S 10,13$. but there was no such allegation in any of these cases. The crime of larceny from a building carried a five-year maximum, apparently without regard to whether it was committed by day or by night. See id. $\$ 15$.

168. Two of the defendants were found not guilty at trial, and two others were found guilty of or pled guilty to larceny only. See Commonwealth v. James Smith, Middlesex Ct. C.P. R. Book 201 (June 1859) (reporting a not-guilty finding after trial); Commonwealth v. Michael Manyer. Middlesex Ct. C.P. R. Book 193 (June 1859) (reporting that the defendant was found guilty after trial, but that the prosecutor then nol prossed that part of the indictment that alleged that the theft was from a building); Commonwealth v. George W. Giles, Middlesex Ct. C.P. R. Book 105 (Feb. 1859) (reporting a not-guilty finding after trial); Commonwealth v. Thomas Murray. Middlesex Ct. C.P. R. Book 92 (Feb. 1859) (reporting that the defendant pled guilty to larceny only and that the prosecutor nol prossed the balance of the indictment). The number of defendants found guilty was actually larger than 35 , because several cases had more than one defendant.

169. This figure does not include two separate cases involving the same defendant, both of which ended in five-year consecutive sentences. See Commonwealth v. Angus Mannon, Middlesex Ct. C.P. R. Book 86 (Feb. 1859); Commonwealth v. Angus Mannon, Middlesex Ct. C.P. R. Book 84 (Feb. 1859).

170. It appears that those defendants who entered into a charge bargain with Morse received more lenient sentences than those who went to trial and lost, but not more lenient than those who simply pled guilty to the entire indictment. Not all these cases are comparable in terms of seriousness, but we can isolate for comparison the eight that charge breaking and entering a residence, since three of the four charge-bargained cases fall in this group. The defendants in the charge-bargained cases received an average sentence of 36 months. See Middlesex Ct. C.P. R. Books (Feb., June 1859); Middlesex Super. Ct. R. Book (Oct. 1859). In two cases, which involved the same defendant, the defendant went to trial, was convicted each time, and received two 60 month sentences, to be served consecutively. In each of the other cases, the defendant pled guilty without any form of charge bargain and received an average sentence of 23 months. See Middlesex Ct. C.P. R. Books (Feb., June 1859); Middlesex Super. Ct. R. Book (Oct. 1859).

171. Of the 39 cases, 15 went to trial. Two ended in not guilty verdicts. The jury returned a split verdict-guilty on one count and not guilty on the other-in eight cases. In three of the remaining five cases, the jury returned a general guilty verdict, and Morse then nol prossed one count of the indictment. In the two cases in which the general verdict apparently stood, there is no sign that the defendant was sentenced on both counts. See Middlesex Ct. C.P. R. Books (Feb.. June 1859); Middlesex Super. Ct. R. Book (Oct. 1859).

172. Although Morse did not abandon charge bargaining in breaking-and-entering cases. the tactic never caught on, and he may have lost enthusiasm for it. In 1864, he charged separate daytime and nighttime counts in nine of 13 indictments for either breaking and entering or larceny from a building. In 1870 , he did so in only seven of 15 such indictments. None of the 1864 cases 
sentencing decision that could make a charge bargain meaningful, Morse succeeded in deploying the tactic against only a few defendants-and they were the most poorly informed.

A difficult question lurks behind Morse's failure to broaden the frontiers of charge bargaining. I have argued that charge bargaining worked only in liquor and murder cases because only in those cases was the penalty scheme rigid enough to allow prosecutors on their own to guarantee sentencing concessions to those defendants who pled guilty. But why did prosecutors have to act on their own? The kind of sentencing power that rigid penalty schemes gave prosecutors mattered only if judges were not partners in plea bargaining. Had judges cooperated in plea bargaining, prosecutors could have bargained in almost any sort of case, even those with wide-open penalty structures.

Two bodies of evidence make it clear that through at least the first half-and probably the first three-quarters - of the nineteenth century, judges generally withheld their cooperation from plea bargaining. The first body of evidence concerns the liquor laws themselves. In 1852, when Massachusetts followed Maine in enacting statewide liquor prohibition, the legislature provided that in cases arising under the new law, "a nolle prosequi shall not be entered by the prosecuting officer, except with the concurrence of the court." 173 Apparently, the legislature had reconsidered its vindication of Asahel Huntington's charge-bargaining practices and reverted to its original, hostile posture. The impact on prosecutorial charge bargaining was immediate and devastating. In 1849, the last year I studied before the law change, Charles Russell Train resolved twenty of fifty-six adjudicated liquor cases with clear plea bargains. In all but one of these, he charged multiple counts; the defendant pled guilty on one or more counts; and Train nol prossed the balance. That year Train sought multiple counts in eighty-nine percent of his liquor indictments-evidence of a concerted plan to gain leverage in anticipation of a plea bargain. ${ }^{174}$

By 1853, having been stripped of his unilateral power to enter nol prosses in liquor cases, Train had abandoned his plan entirely, Not only did he not engage in a single plea bargain on the old model, it appears that he did not seek a single multi-count liquor indictment. ${ }^{175}$ As a result, of

and only one of the 1870 cases ended in a charge bargain involving a nol pros of one of the two counts. See Middlesex Super. Ct. R. Books (Feb., Oct. 1864; Feb. 1870).

173. Act of May 22, 1852, ch. 322, § 13, 1852 Mass. Acts 257, 257.

174. See supra notes $80-81$ and accompanying text.

175. The sample size here is small, however. The records in 1853 disclose only seven cases in which the clerk made it clear both that Train sought an indictment under the new prohibition law and how many counts he charged. The rest of the adjudicated liquor cases came to the Cour of Common Pleas not via grand jury indictment, but as appeals from lower tribunals. It docs not appear that the district attomey dictated the charging practices in such cases, and they only marely involved multiple counts either before or after the law change of 1852 . Unfortunately the clerk often recorded only that a case charged violations of the liquor-license law or of the prohibitory 
twenty-four liquor cases adjudicated in 1853, twenty-one ended in trials. Only three ended in plea bargains, and all of these involved the somewhat covert plea-bargaining technique of placing the cases on file, which I will take up in Part III. By 1859, the volume of adjudicated liquor cases had grown, perhaps as authorities got used to the new law, but the pattern of disposition stayed much the same. Forty-three of the sixty-two adjudicated liquor cases ${ }^{176}$ ended in trials; three ended in simple guilty pleas with no evidence of a concession; ${ }^{177}$ and all sixteen plea bargains took the on-file form. In fact, virtually the only plea bargains that survived in liquor cases after 1852 were of the on-file variety. Only four of the 602 liquor cases in the years I studied between 1853 and 1910 ended in a plea bargain of the sort Train used so extensively in $1849 .{ }^{178}$

It would be hard to attribute the sudden death of multiple-count plea bargaining in liquor cases to any other aspect of the 1852 prohibition law than its elimination of the nol pros as a prosecutorial prerogative. The new law left in place the mandatory penalty scheme that had made the old license law so conducive to plea bargaining: Being a common seller, for example, still carried a mandatory $\$ 100$ fine, and making a single sale carried a fixed fine of ten dollars. ${ }^{179}$ If the 1852 law effectively killed charge bargaining in liquor cases, it must have been because judges disapproved of the practice. The law did not ban nol prosses outright, but banned them "except with the concurrence of the court." That charge

law, without enumerating counts. See Middlesex Ct. C.P. R. Book (1853) (on file with the Massachusetts Archives).

176. In 1855 , the legislature had broadened the state's criminal nuisance law to embrace the act of keeping a liquor tenement. See Act of May 19, 1855, ch. 405, 1855 Mass. Acts 803, 803. Thereafter, "liquor nuisance" cases became quite common. Because the penalty scheme of the nuisance law was very different from those of the old license law and of the new prohibition law. it would be wrong to lump the liquor-nuisance cases with the rest. Whenever I refer simply to "liquor" cases, therefore, I mean either liquor-license cases or prohibition cases, depending on the governing statute at the time--but not liquor-nuisance cases. Liquor-nuisance cases must languish in limbo, as neither "liquor" nor "non-liquor" cases. See infra Appendix A.

177. Because the prohibition law, as reenacted in 1855, called for mandatory imprisonment. these defendants all served time. See Act of Apr. 20, 1855, ch. 215. \$\$ 15, 17, 24, 1855 Mass. Acts 623, 630, 631, 635; Commonwealth v. James Campbell, Middlesex Ct. C.P. R. Book 144 (June 1859) (noting a sentence of 20 days and a fine for a single sale of liquor); Commonwealth $v$. John Healey, Middlesex Ct. C.P. R. Book 22 (Feb. 1859) (same); Commonwealth v. John Healcy. Middlesex Ct. C.P. R. Book 24 (Feb. 1859) (same).

178. The anomalous cases are Commonwealth v. Richard Barrett, Middlesex Super. Ct. R. Book 85 (Feb. 1874); Commonwealth v. Edward Riordan, Middlesex Super. Ct. Docket Book No. 510 (Feb. 1864); Commonwealth v. Nicholas Mullen, Middlesex Super. Ct. Docket Book No. 488 (Feb. 1864); and Commonwealth v. Catherine Conley, Middlesex Super. Ct. Docket Book No. 461 (Feb. 1864). In Barrett, the record does not specify that the prosecutor in fact entered a nol pros. I have included this case in the list, however, because it is clear that Barrett pled to one count among several, that he was fined only on that count, and that the one count carried only a small fine. The case therefore had all of the other earmarks of a liquor charge bargain.

179. See Act of May 22, 1852, ch. 322, $\S \$ 7,12,1852$ Mass. Acts 257, 257. Unlike the old law, though, the new law provided mandatory prison terms on third offenses and required the posting of $\$ 1000$ or $\$ 2000$ bonds as surety against future violations. See id. 
bargaining in liquor cases died compels one conclusion: Judges withheld their concurrence.

The second body of evidence of judicial resistance to plea bargaining concerns the resolution of non-liquor cases in the first third of the century. The records of the Court of Common Pleas show that from 1789-the earliest year I studied-through 1829, between forty-eight percent and seventy-two percent of adjudicated non-liquor cases ended in pleas of guilty or no contest. ${ }^{180}$ Despite these very high plea rates (which soon fell dramatically for reasons I will take up in Part IV), there is no evidence that plea bargaining was going on. That is, there is no evidence that these defendants won some understood concession for their pleas. Court records reflect a near-total absence of the sort of charge bargains I examined in Part I, in which the clerk's record made the nature of the concession clear. Outside the liquor-law context, only four such bargains appear in the fourteen years I studied between 1789 and $1829 .{ }^{181}$ Because the penalty scheme in non-liquor cases left wide discretion in the judge's hands, the prosecutor could not dictate the sentence by manipulating charges-so any effective charge bargain required the judge's participation. The lack of charge bargaining in non-liquor cases, then, is some evidence that judges were not yet allies in prosecutors' plea-bargaining designs.

There is, moreover, no evidence of sentence bargaining in non-liquor cases during these early years. A numerical analysis of sentencing patterns discloses no sign of a well-understood practice of granting lighter sentences

180. Here are the results of my case counts for the following years:

PRoportion of AdJudicated NON-LIQUOR CaSES ENDING IN PLEas of GUILTY OR NO CONTEST

\begin{tabular}{|c|c|}
\hline $1789-1790$ & $71 \%$ \\
\hline $1799-1800$ & $63 \%$ \\
\hline $1805-1806$ & $59 \%$ \\
\hline $1809-1810$ & $48 \%$ \\
\hline $1814-1815$ & $53 \%$ \\
\hline $1819-1820$ & $59 \%$ \\
\hline 1824 & $56 \%$ \\
\hline
\end{tabular}

Sources: Middlesex CL. C.P. R. Books (on file with the Massachusetts Archives).

181. See Commonwealth v. Joseph Jeffrey Jr., Middlesex Cl. C.P. R. Book 375 (Dec. 1824) (reporting a case charging damaging a highway in which Steams nol prossed one of two counts after the defendant pled no contest to the other); Commonwealth v. Simeon Gigger. Middlesex $\mathrm{Ct}$. C.P. R. Book 34 (Dec. 1820) (reporting a case charging breaking and entering a dwelling house and committing assault and battery in which the defendant pled guilty to assault and battery only and was sentenced on that basis); Commonwealth v. Simeon Ford. Middlesex C. C.P. R. Book 450 (June 1815) (reporting a case charging travel on Sunday in which the prosecutor nol prossed one of two counts after the defendant pled guilty to the other): Commonwealth v. George Peters. Middlesex Ct. Gen. Sess. Peace R. Book 7 (Sept. 1790) (discussed supra note 32). In a fifth case, there was a clear concession but not precisely a charge bargain. See Commonwealth v. Jonathan Curtis, Middlesex Ct. C.P. R. Book 371 (June 1814) (reporting an assault-and-battery case that Asahel Stearns nol prossed upon costs after the defendant's plea of no contest). 
to those defendants who pled guilty. True, any such analysis is risky in this context. Each case has many unknown sentencing variables, including the defendant's background, the specific details of the crime, and the judge's habits and moods. More importantly, even if one had a large enough sample to smooth out such variations, a systematic bias still might slant the outcome: Those defendants who faced the heaviest sentences might have been more likely to go to trial, so even absent any form of plea bargaining, sentences might have been heavier after trial than after a plea. This risk of bias means that a pattern of higher sentences after trial would not necessarily indicate the presence of plea bargaining-but the absence of such a pattern probably would be evidence of the absence of plea bargaining.

The only non-liquor crime to appear during the early years of this study often enough to permit numerical analysis was simple theft. ${ }^{182}$ Before 1809 , the punishment of thieves generally involved whippings, restitution, and sale into servitude, often as alternatives to one another or to incarceration. ${ }^{183}$ Rather than try to compare lashes and bondage with our modern punishments of prison time and fines, I have chosen to examine only those theft cases from 1809 or later, and I have excluded the few cases in those years that still authorized servitude. In the eight years I studied between 1809 and 1829, forty-three cases of simple theft ended in convictions and sentences of either time or fines. Fortunately, indictments in theft cases almost always attached an exact dollar figure to the goods stolen, so we have some way to judge whether the more serious cases tended to go to trial. As it happened, the average value of the goods stolen was very nearly the same- $\$ 14.02$ for cases ending in a plea and $\$ 14.08$ for those ending in a conviction after trial. And in fact, the likelihood that the defendant would go to prison was the same in both sets of cases-eighty-eight percent. But those accused thieves who pled guilty tended to suffer heavier sentences than those who went to trial and lost-on average drawing 2.5 months as opposed to only 1.8 months.

182. I am excluding liquor cases from this portion of the study because in those cases, prosecutors held the balance of sentencing power. In later years, breaking-and-cntering and assault-and-battery cases were common enough to allow analysis. See infra notes 502-505 and accompanying text. Between 1789 and 1829 , however, I saw only a handful of breaking-andentering convictions, and although assault-and-battery cases were more plentiful, far too few (only six) ended in convictions after trial to permit comparison with convictions by plea.

183. See, e.g., Commonwealth v. Daniel Nix, Middlesex Ct. Gen. Sess. Peace R. Book 458 (Sept. 1789) (providing for various sentencing alternatives, including whipping, restitution, salc into servitude, and incarceration at hard labor). 
TABLE 1. SENTENCE ACCORDING TO MODE OF CONVICTION IN THEFT CASES: MIDDLESEX COURT OF COMMON PLEAS, 1809-1829

\begin{tabular}{|l|c|c|}
\hline & After Plea & After Trial \\
\hline Number & 26 & 17 \\
\hline $\begin{array}{l}\text { Avg. Value of } \\
\text { Stolen Goods }\end{array}$ & $\$ 14$ & $\$ 14$ \\
\hline \% Prison & 88 & 88 \\
\hline $\begin{array}{l}\text { Avg. Term } \\
\text { (months) }\end{array}$ & 2.5 & 1.8 \\
\hline$\%$ Fine & 12 & 18 \\
\hline Avg. Fine & $\$ 13$ & $\$ 20$ \\
\hline $\begin{array}{l}\text { \% Assessed } \\
\text { Costs }\end{array}$ & 23 & 18 \\
\hline Avg. Costs & $\$ 23$ & $\$ 41$ \\
\hline
\end{tabular}

Source: Middlesex C. C.P. R. Books.

I believe this evidence, together with that presented over the last several pages, is enough to show that judges in the early nineteenth century generally were not partners in plea bargaining. Prosecutors therefore had to bargain where they could-that is, in liquor cases. In Part IV, I will ask what moved so many defendants in the first third of the century to plead guilty when they won no apparent concession in exchange. Now the important question is why no concession was forthcoming. Why didn't judges reward defendants for their guilty pleas? And why didn't they at least go along with prosecutors' attempts, after 1852 , to enter nol prosses in liquor cases?

The first and most fundamental reason is that judges lacked prosecutors' incentives to plea bargain: They neither faced the same workload pressure nor found the same advantage in the certain (prosecutorial) victory of a plea. Their workload pressure was lower in part because they earned full-time salaries. In 1821 the legislature set salaries at $\$ 2100$ for the chief justice of the Court of Common Pleas and $\$ 1800$ for each of the associate judges, ${ }^{184}$ as compared to the $\$ 1000$ that Asahel Huntington earned ${ }^{185}$ until the legislature reduced his salary to $\$ 700$ in $1843 .{ }^{186}$ (As late as 1849 , a salary of $\$ 2500$ for the state's attomey general

184. See Act of Feb. 14, 1821, ch. 79, $§ 10,8$ Mass. Laws 545, 551. This act did not establish the Court of Common Pleas, but rather the "Court of Common Pleas for the Commonwealth," one variant in the institution's evolution. See supra note 7.

185. See Act of March 14, 1832, ch. 130, $\S 10,12$ Mass. Laws 396, 406.

186. See Act of Mar. 7,1843, ch. $9, \S 1,1843$ Mass. Acts $6,6$. 
was considered "a good one." ${ }^{187}$ ) Although there seems to have been no law that barred judges from receiving outside income, ${ }^{188}$ I have seen almost no evidence that any judge carried on a law practice or other trade. ${ }^{189}$ It is true that four of the five judges of the Court of Common Pleas resigned their posts in indignation after the legislature reduced their salaries to $\$ 1700$ in $1843 .{ }^{190}$ But four new judges quickly took their spots, ${ }^{191}$ and by 1867 , associate judges of the Superior Court were drawing $\$ 4200,{ }^{192}$ while the Middlesex district attorney languished at $\$ 1200 .^{193}$

Still, I do not suggest that huge caseload increases, especially those of the 1840 s, did not burden judges. That the legislature expanded the Court of Common Pleas from four judges to seven between 1843 and 1851 makes it plain that all parties thought there was stress on the court. ${ }^{194}$ But because judges drew full-time salaries and apparently sought no livelihood elsewhere, they lacked prosecutors' financial incentives to dispose of cases as quickly as possible. For them, a day spent trying criminal cases was not a day's civil income lost. Moreover, the judges profited from the sheer overwork of the district attorneys: A part-time unassisted prosecutor could

187. Letter from B[enjamin] R. Curtis to John H. Clifford (Apr. 28, 1849) (on file with the Massachusetts Historical Society, John H. Clifford Papers, Box 1845-1851, 1848-1849 Folder).

188. A bill proposed in 1811 would have made it a "high misdemeanor" for any Court of Common Pleas judge to appear as an attomey before a state or federal court or to take part in any civil case. See Act To Prohibit the Justices of the Court of Common Pleas from Practising as Attomies or Counsellors (on file with the Harvard Law School Library). This bill does not seem to have become law and in any event would have fallen under a general repeal provision of the 1821 legislation. See Act of Feb. 14, 1821, ch. 79, § 12, 8 Mass. Laws 545, 551.

189. The only evidence I have seen of a judge's doing legal work on the side appears in the diaries of Charles Thompson (1827-1894), a lawyer based in Salem who was appointed to the superior court in 1885. Thompson's diaries note that in May 1886 he "went to Probate Court on Probate of will of Fitz E. Riggs." 13 Diaries of Charles Thompson (May 8, 1886) (on file with the Harvard Law School Library). Thompson had handled the Riggs will before his appointment to the bench. See 13 id. (Feb. 24, 1885) (making reference to the will of Fitz E. Riggs); 11 id. (Oct. 14,1885 ) (noting his nomination to the Superior Court). There is no reason to believe that Thompson took on new business after his appointment, but neither did he immediately wrap up his old business.

Samuel Dana served in the Massachusetts Senate from 1811 to 1813 and in Congress from 1814 to 1815 even while he sat on the Court of Common Pleas. See DAVIS, supra note 7, at 20204, 219-20. Perhaps for this reason, the legislature provided that its 1821 salaries were "in full for [the judges'] services" and that if any judge should accept a legislative seat or federal position. "his office of the Justice of the Court of Common Pleas shall thereby be vacated." $\$ 10,8$ Mass. Laws at 551. But as the legislature repealed this restriction four months later, see Act of June 16. 1821 , ch. $23, \S 4,8$ Mass. Laws 595,595 , it is possible that other judges took multiple posts in later years.

190. See $\S 1,1843$ Mass. Acts at 6; AlAN J. DIMOND. ThE SUPERIOR COURT OF MASSACHUSETTS 78 (1960).

191. See DAVIS, supra note 7, at 244.

192. See DIMOND, supra note 190 , at 75-76.

193. See Act of Apr. 6, 1859, ch. 216, $\S 1,1859$ Mass. Acts $371,371$.

194. See DAVIS, supra note 7, at 244; see also Court of Common Pleas, Lowell J.. Sept. 10. 1847 , at 1 ("Something ought to be done to enable our courts to d[i]spatch business, so that parties going to law, may do so with a reasonable prospect of settling their disputes in their lifetime."). 
charge and try only so many cases and therefore could put only so much pressure on a judge. Yet the Middlesex district attorney's salary did not begin to resemble a full-time salary until 1872 , when the legislature raised it to $\$ 2000,{ }^{195}$ and I have seen no hint of an assistant district attorney in Middlesex before $1875 .{ }^{196}$ When the district attorneys found themselves unable to manage their caseloads, they simply cleaned out their backlog by entering nol prosses en masse. ${ }^{197}$ And if judges were therefore somewhat protected from the caseload pressures that plagued prosecutors, they felt perhaps not at all the prosecutor's second incentive to plea bargain-that it meant a clear victory.

Lacking prosecutors' clear incentives to plea bargain, judges may have found themselves more troubled than prosecutors by a principled objection to the practice. In the great majority of cases, the legislature had entrusted judges with very broad sentencing discretion entirely free from review. Once a judge chose a sentence of between zero and twenty years for manslaughter,${ }^{198}$ for example, no higher court could adjust the sentence, nor could any authority short of the governor release the defendant from it. ${ }^{199}$ The notion of taking part in a plea bargain must have deeply offended any judge who felt the full weight of this burden. No judge could promise in good conscience to impose a particular sentence when ignorant of those facts most critical to the choice of sentence-the details of the crime and the defendant's character and criminal history. And the judge had no unbiased source of this information. It is easy to understand in this light a Michigan judge's affronted response to a defense lawyer's inquiry whether the judge would impose a certain sentence if the defendant pled guilty: "I informed him," reported the judge, "that it would be time enough for me to determine what the sentence should be after the respondent was convicted." ${ }^{200}$ In fact, there seems to have been a widespread if not uniform

195. See Act of May 6, 1872, ch. 353, $\S 1,1872$ Mass. Acts $320,320$.

196. In 1875, the legislature provided for a part-time assistant district attomey for the northern district (Middlesex) and others. See Acl of Feb. 11, 1875, ch. 12, $\$ 1,1875$ Mass. Acts 602,602 . A law of 1873 permitted appointment of a clerk to assist the district attomeys. See Act of May 12, 1873, ch. 278, $\$ 1,1873$ Mass. Acts 707,707 . The first indication I have seen of a possibly full-time assistant prosecutor in Middlesex is in an 1881 county payroll showing $\$ 1000$ disbursed for an assistant district attomey, raised to \$1500 the following ycar. See MIDDLESEX COUNTY, STATEMENT OF RECEIPTS AND EXPENDITURES OF THE COUNTY OF MIDDLESEX FOR THE YEAR ENDING DECEMBER 31, 1881, at 5 (n.p., n.d.); MIDDLfSEX COUNTY. STATENENT OF RECEIPTS AND EXPENDITURES OF THE COUNTY OF MIDDLESEX FOR THE YEAR ENDING DECEMBER 31, 1882, at 5 (n.p., n.d.).

197. See supra note 131 and accompanying text.

198. See MASS. GEN. STAT. ch. 160, § 18 (William White 1860).

199. This was also true elsewhere. See ARTHUR TRAIN, THE PRISONER AT THE BAR 178 (1906) (noting that sentences in New York as of 1906 "cannot be considered or reversed on appeal"). Arthur Train was Charles Russell Train's son. See infra note 474 and accompanying text.

200. People v. Brown, 54 Mich. 15, 20 (1884). After the defendant pled guilty but before sentencing, the judge told others who approached him on the defendant's behalf "that I would 
nineteenth-century practice of holding a sentencing hearing, perhaps involving witnesses, even after a defendant pled guilty. ${ }^{201}$ Such a hearing could enable judges to pass a conscientiously well-informed sentence, but could not become an aid in plea bargaining. As the hearing followed conviction, it could not assist the judge in determining what concession he should offer the defendant should she plead guilty.

If the sentencing power became in judges' minds a symbol of their great authority and esteem, then it would be no surprise if they bristled at prosecutors usurping any part in the course of striking a plea bargain. Here we stray from an objection founded on principle to one based on pride. I have seen no expression of judicial attitudes toward prosecutorial plea

examine into the previous history of the respondent and consider any mitigating circumstances that there might be in his case, and that I was not prepared to announce in advance what his sentence would be." Id. at 21 . Of course, as the quoted statement comes from the judge's own account of events supplied to the state's supreme court on the defendant's appeal following his guilty plea, it perhaps says more about the appropriate response to a defense lawyer's inquiry than about the actual response.

201. An 1837 issue of the Lowell Courier reported that at the Court of Common Pleas, a defendant "pleads guilty, and on examination of witnesses is sentenced to common gaol 2 mos." Court of Common Pleas, Lowell CouRIER, Sept. 14, 1837, at 2. The same report includes several other cases in which defendants pled guilty and were sentenced without any mention of further proceedings. See id. I cannot say whether the first case was exceptional or-what secms just as likely - the reporter simply neglected to mention a similar hearing in other cases. The court's records never mention sentencing hearings, though they surely took place often.

A superior court judge wrote in an 1867 trial notebook that a defendant "plead Guilty of assault \& Battery-as to sentence Mr W.E Jewett states that it was an accidental struggle." Charles Devens Notebooks (Norfolk, Apr. 1, 1867) (unpublished and unpaginated document, on file with the Massachusetts Historical Society). Although it seems likely that "Jewett" was the defendant's lawyer and not a witness, this entry nevertheless makes it clear that there was a sentencing hearing at which the judge was paying attention, suggesting no previous agreement on sentence.

In 1886, a New Bedford lawyer recorded the following charge bargain in his diary: "In Taunton A.M. . . . engaged in the trial of John Connerlly for larceny \&c. The case was nol pros \& Connelly [sic] plead guilty to receiving stolen goods \&c . ..." 3 Diaries of Edwin L. Barncy 26 (Mar. 9, 1886) (unpublished document, on file with the Massachusetts Historical Society). The next day the lawyer wrote that he had returned to Taunton "about Connlly [sic] sentence." $3 \mathrm{id}$. at 26 (Mar. 10, 1886). He noted at least one other time that he had addressed the court on the question of sentence after his client had pled guilty. See 1 id. at 82 (Sept. 22, 1859); see also 11 Thompson, supra note 189 (May 13, 1885) ("At Newburyport-Case of Geo W Colbum[.] He plead guilty. Spoke as to sentence \& matter postponed.").

An Illinois statute of 1845 provided that "[i]n all cases where the courts possess any discretion as to the extent of the punishment, it shall be the duty of the court to examine witnesses as to the aggravation and mitigation of the offence." Act of Mar. 3, 1845, ch. 300, \& 183, 1845 Ill. Rev. Stat. 185, 185. Friedman and Percival report that according to a California statute, see Act of Apr. 20, 1850, ch. 119, 1850 Cal. Stat. 310, 310, "[a]fter conviction, the judge was supposed to wait at least two days before fixing sentence .... But over one-third of the defendants waived their rights and were sentenced the day they were convicted." FrIEDMAN \& PERCIVAL, supra note 135, at 201.

Arthur Train reported in his 1906 book that a particular defendant pled guilty, after which "his pedigree [was] taken and a day set for his sentence." TRAIN, supra note 199, at 152-53. At sentencing hearings, "[a]ffidavits, letters, newspaper clippings and memoranda are submitted tending to show that [the defendant] is of either good or bad character, [and] has had a reputable or a disreputable past." Id. at 193. 
bargaining during the first half of the nineteenth century, when the practice first emerged. But around the turn of the century, at a time when one might have thought judges had grown reconciled to the phenomenon, they bitterly voiced their resentment. In 1897, the Rhode Island Supreme Court considered a nuisance case in which the prosecutor had entered a nol pros on condition of the defendant's payment of $\$ 100$ plus costs. "We are aware," the court wrote,

that the custom has obtained, to a considerable extent, for the attorney-general to compromise or settle this class of cases, as well as cases arising under the liquor law, upon the payment of a certain sum of money to the State by the defendant; but the practice is a vicious one, and meets with our entire disapproval. There is no law authorizing a sentence or any legal substitute therefor by consent of parties, without the imposition thereof by the court. ${ }^{202}$

In 1913, a former chief justice of Maine's Supreme Judicial Court put in still harsher terms his opinion of the way prosecutors deployed their nol pros powers:

A reprehensible practice ... is said (and I fear with some truth) to have obtained in some counties for the prosecuting officer, even after conviction sometimes, to grant a nolle prosequi in consideration of the defendant's paying into the county treasury such sum of money as the officer may fix upon .... [This practice] is a plain, inexcusable usurpation of a power entrusted to the courts, the power of determining what the penalty should be within the limits fixed by the legislature. ${ }^{203}$

The author wondered at the effrontery of prosecutors who imagined "that they are better judges than the court of what is an adequate penalty for the offense." 204

Plea bargaining in the early and mid-nineteenth century therefore encountered at least three obstacles to judicial acceptance: It served judges' needs less well than those of prosecutors; it met in some judges a principled aversion to discharging their awesome duty to sentence without full information; and it offended some judges' pride of power. As a result, prosecutors could plea bargain only where they could do so on their own, without judicial cooperation - and that meant only in liquor crimes and capital offenses. But as I have said, both Ferdinand and Vogel arrive at

202. State v. Conway, 20 R.I. 270, 273 (1897).

203. Ex Chief Justice Emery, The Nolle Prosequi in Criminal Cases, 6 ME. L. REv. 199, 202 (1913)

204. Id. at 202-03. 
different explanations of the early rise of plea bargaining. It is time now to take up their evidence.

\section{Competing Theories}

\section{The Role of Absent Victims and Savvy Defendants}

Theodore Ferdinand's massive survey ${ }^{205}$ of the court records of Boston, like my more modest study of Middlesex, produced solid evidence of a special relationship between liquor-license cases and plea bargaining in the first half of the nineteenth century. Just over half of the liquor-license cases in his sample ended in guilty pleas, as compared to only twenty-six percent of typical common-law crimes such as larceny and felony assault. ${ }^{206}$ Moreover, the rate of guilty pleas in liquor cases increased greatly in the $1840 \mathrm{~s} .{ }^{207}$ Although Ferdinand's statistics do not separate simple guilty pleas from clear plea bargains, as I use the term, he does report a vigorous practice of multiple charging and suggests anecdotally that the tactic was a favorite in liquor cases. ${ }^{208}$ Hence, he tells us of Peter Bent Brigham, whose name survives on a Boston hospital, but who in humbler days in the $1840 \mathrm{~s}$ came repeatedly to court to face a raft of liquor-law charges. Brigham pled guilty each time to one count and paid his modest fine. ${ }^{209}$

In other ways, Ferdinand's account of the early rise of plea bargaining differs from mine. He argues, for example, that Boston constables "invented" plea bargaining in the 1830 s as a natural spinoff of the negotiations they conducted with criminals for information about other crimes or for the return of stolen goods. ${ }^{210}$ The prosecutor, who "could readily appreciate [plea bargaining's] many advantages, and ... was in a position to implement it quickly," then expanded the practice that the constables had devised. The notion that Boston constables invented plea bargaining in the 1830s suggests that there was something so complicated about plea bargaining that constables had to invent it for prosecutors. Yet in

205. Ferdinand reports that his "data collection team" coded over 36.000 cases from the Boston Police Court between 1826 and 1850 and 9200 cases from the Boston Municipal Court, the analogue to the Court of Common Pleas elsewhere in the state. See FERDINAND, supra notc 121 , at 215 .

206. See id. at 50 tbl.2.2. Ferdinand concludes that "[t]here is little evidence that common law crimes or private disputes were regularly plea bargained in either [the Police or the Municipal] court during the antebellum period." Id. at 92; see also id. at 74-81 (arguing from a variety of evidence that there was a low incidence of plea bargaining in common-law offenses).

207. See id. at 59 tbl.2.3 (showing a leap in the rate of guilty pleas in "regulatory offenses" from $24.2 \%$ of all cases in 1814-1840 to 55.2\% in 1842-1850); see also infra Appendix B (breaking down "regulatory offenses").

208. See FERDINAND, supra note 121 , at 77,79 tbl.3.6.

209. See id. at 77 . Ferdinand does not say what became of the other counts.

210. See id. at $13,15,66,95,186$. 
Middlesex County, Samuel Dana hit upon a very elaborate form of plea bargaining in 1808,211 Asahel Stearns used Dana's model in the $1820 \mathrm{~s}^{212}$ and by 1834 , around the time Ferdinand credits Boston constables with inventing the practice, Asahel Huntington had refined it with his preprinted, multi-count indictment forms. ${ }^{213}$ As we will see in Part VI, plea bargaining had appeared in scattered other places long before its invention in Boston. That two parties might trade concessions in order to trade gains surely was not a new concept, and it took little inspiration to extend such familiar tactics to the criminal courts.

It did, however, take power. Unless the prosecutor could guarantee a sentencing concession in exchange for the defendant's plea, no bargain was likely to happen. Yet Ferdinand does not ask how it was that prosecutors were "in a position to implement" plea bargaining in liquor cases. In seeking to explain the early connection between plea bargaining and liquor cases, ${ }^{214}$ he does not speak of the license law's rigid penalty scheme or the unusual power to craft charge bargains that it bestowed upon prosecutors. Instead he looks largely to the absence of a victim in liquor cases and to the presence of savvy, business-wise defendants. These factors have some appeal in setting liquor cases apart from most others, but perhaps less than at first appears.

Ferdinand sees two reasons why victimless crimes might have made fertile ground for plea bargaining. The less important, which he notes only in passing, is that there was no injured party to agitate for complete vindication of justice and to resist any proposed plea bargain. ${ }^{215}$ Ferdinand does not lean hard on this argument, perhaps because he realizes that liquor crimes were not entirely victimless. Townspeople often made angry demands that prosecutors rid them of their corner tavern-keeper. ${ }^{216}$ And

211. See supra notes 21-25 and accompanying text.

212. See supra note 46 and accompanying text.

213. See supra notes 57-63 and accompanying text.

214. Ferdinand gives a broader label than "liquor cases" to those violations in which he finds a high rate of plea bargaining in the Boston Municipal Court for the first half-century. He calls them "vice or regulatory" cases. FERDINAND, supra note 121, at 81; see also supra note I59 and accompanying text (illustrating Ferdinand's use of the word "regulatory"). Regulatory offenses consisted entirely or almost entirely of liquor-selling crimes, while vice offenses included some that were punishable under the liquor-license law. Demonstrating the affinity between what Ferdinand refers to as "vice or regulatory" offenses and what I call liquor-law violations requires some close statutory analysis, which I will defer unil Appendix B.

215. See FERDINAND, supra note 121. at 93 (“The complainant in such cases was inevitably someone who would understand and accept a reduced punishment ... ."); id. at 60 ("Since few victims followed the prosecution of these cases or took note of their resolution. regulatory and vice cases offered a wide latitude for experimentation.").

216. See infra note 277 (quoting at length from a townsman's Ictter to Asahel Huntington and citing a second, similar letter); see also Commonwealth v. Asa B. Cobleigh. Middlesex Cl. C.P. File Papers, No. 130 (Feb. 1850) (containing a letter to Charles Russell Train from a citizen who complained of the defendant's gambling activities, and listing witnesses to the defendant's gambling and liquor selling); infra Appendix B (addressing the connection between the liquor law and gambling offenses). 
although Ferdinand does not look at the work of the Supreme Judicial Court and does not write of plea bargaining in capital cases, he surely would not claim that murder cases lacked victims, though they were a source of vigorous plea bargaining in the middle of the century.

Ferdinand puts more weight on the argument that victimless crimes could end up in court only if the authorities actively went out to investigate. "[T]he investigating official," he notes, "was someone who could also begin negotiations." 217 Yet Ferdinand offers no evidence that liquor prosecutions in fact inevitably arose from official action, and there is some reason to think that official instigation was more the exception than the rule. ${ }^{218}$ Nor does he ask how so many non-liquor defendants-for example, burglary suspects, who rarely pled guilty ${ }^{219}$-managed to find their way into court without the aid of an investigating official "who could also begin negotiations." 220

As for savvy defendants, Ferdinand argues that those accused of liquor crimes "were often businessmen... [who] recognized the waste in seriously contesting minor charges that carried little stigma" and who were therefore ready to negotiate. ${ }^{21}$ Ferdinand surely is right that unless defendants saw a comparative advantage in pleas over trials, no plea bargain could take place. And he may be right that tradespeople were somewhat quicker than others to see the value of a good bargain. But I suspect that Ferdinand carries this argument too far when he suggests that it does much to explain why liquor laws came first in plea bargaining's chronicles. He does not, after all, consider how burglars and robbers, streetwise in so many ways, could have been dull to the benefits a plea bargain could promise. Nor does he consider whether defense counsel might have helped less savvy defendants to see the value of a good bargain. ${ }^{222}$

217. FERDINAND, supra note 121 , at 93.

218. Robert Hampel reports that in Taunton, Massachusetts, between 1834 and 1845, "[ $t$ )he great majority of the complainants [in liquor prosecutions]... were volunteers" of various temperance organizations. HAMPEL, supra note 65 , at 148 . He adds, with regard to the state as a whole, that "[t]he task of prosecuting sellers and drunkards did not fall on the local police." $I d$. Boston was surely a very different place from Taunton, and Hampel does not appear to have studied Boston in any depth, but his findings counsel caution in reaching conclusions about Boston.

219 . Only $26 \%$ of burglary defendants pled guilty over the course of Ferdinand's study. See FERDINAND, supra note 121, at 50 tbl.2.2.

220. Id. at 93.

221. Id. at 94.

222. Ferdinand notes almost in passing that "defense attorneys were not common" in the Boston Municipal Court in the period of his study. Id. at 99; see also id. at 185 ("Defendants were permitted lawyers, ... but most often they were unrepresented ...."). It is possible, though, that the particular documents he examined would not have disclosed the presence of counsel in most cases. Ferdinand's appendix on his method, although not quite clear on the point, suggests that he looked only at the "record books" for the municipal court. See id. at $211,213,215$. I found in my work in the Middlesex Court of Common Pleas-a close analogue of the Boston Municipal 
I will not press these points, however, because the lack of individual victims in liquor cases and liquor defendants' frequent status as tradespeople probably did accelerate, if not cause, the progress of plea bargaining in liquor cases. The real shortcoming of Ferdinand's theory of the evolution of plea bargaining is that its powers of explanation expire almost precisely at mid-century, when his study ends. Just two years into the second half of the century, the legislature withdrew the prosecutor's power to enter nol prosses in liquor cases and, as we have seen, killed prosecutorial charge bargaining. Whatever may have been the role of absent victims and savvy defendants in facilitating charge bargaining in liquor cases, these factors were not sufficient to keep the practice alive. In nineteenth-century liquor cases, the prosecutor's unilateral power to nol pros was apparently a necessary condition for charge bargaining to take place.

And despite Ferdinand's arguments about absent victims and savvy defendants, the prosecutor's ability to use his nol pros power to shape the defendant's sentence was also apparently a sufficient condition for charge bargaining to take place. The history of charge bargaining in murder cases suggests as much. Murder was hardly a victimless crime, and the victim's friends and family no doubt pressed for quick and vigorous prosecution. Nor were murder defendants particularly savvy. Although they almost always had counsel appointed free by the state, they lacked the commercial sophistication of liquor dealers. Yet even as charge bargaining in liquor cases disappeared altogether after the legislature withdrew the prosecutor's nol pros power in 1852, charge bargaining in murder cases showed huge gains. The legislature's action had applied only to liquor cases, and prosecutors in capital cases continued unhindered in their practice of entering partial nol prosses in exchange for the defendant's plea to a lesser charge.

\section{A Cultural and Political Approach}

Mary Vogel's study proceeds from a different body of evidence than do mine and Ferdinand's and arrives at very different conclusions about the forces that gave rise to plea bargaining. Vogel conducted her research at the Boston Police Court, a non-jury forum that usually operated without a professional prosecutor and occupied the lowest tier of Boston's judicial

Court - that the record books rarely noted defense counsel. Beginning in 1844, however, the court's "docket books" regularly recorded counsel in criminal cases. As I will report in Part IV. over half of all defendants in the Middlesex Coun of Common Pleas had counsel at the century's midpoint. See infra note 436 and accompanying text. 
system. ${ }^{223}$ Liquor-license cases played a very small role in that court's business, ${ }^{224}$ and in her latest work, Vogel reports no link between plea bargaining and alcohol-related cases. ${ }^{225}$ Her theories therefore address the rise of plea bargaining in general.

There is good reason to expect that Vogel's findings in the Boston Police Court would differ greatly from Ferdinand's and mine in the courts of the middle tier. In the police court, the only authority with the power to grant the defendant a concession in exchange for his guilty plea was the presiding magistrate. That same magistrate would also decide the issues of guilt and sentencing should the defendant choose trial instead. In such a setting, the notion of a plea "bargain" surely meant something different than in a jury court. Once a police court magistrate had told the defendant what he believed the case to be worth, the defendant knew the magistrate could achieve that result equally well after trial as after plea. Because there was no jury, the independent judgment of a jury could pose no obstacle to the sentence the magistrate intended to impose. In contrast, defendants in the courts of the middle tier could reject a plea offer in the hope of winning an acquittal from a jury and so could engage the authorities in a true bargaining process.

Such concerns about the roles and powers of various courtroom actors, central to my analysis and important to Ferdinand's as well, draw little of Vogel's attention. ${ }^{226}$ She sets her work apart from those who focus on "the prosecutor, the police, trial complexity, and crowding in the courts" ${ }^{227}$ and looks instead to the "social structural and institutional context" of plea bargaining. ${ }^{228}$ Having concluded from her data that plea bargaining in Boston emerged in the 1830s and 1840s, Vogel focuses on the culture and politics of those decades.

It was a time of riots and unrest, she writes, and Boston's Whig elite found itself striving to regain social order. ${ }^{229}$ But it was also a time of

223. See Vogel, supra note 146, at 59 fig.1 (identifying the Boston Police Court as the source of her data on guilty-plea rates through 1866); Vogel, supra note 148, at 170-72 (same, for the period from 1830 to 1860 ); $i d$. at 218 (noting that prosecutors appeared rarely in the police court before 1850); see also FERDINAND, supra note 121, at 46 (noting the absence of a jury in police court).

224. See Vogel, supra note 148 , at $173-74$ tbl.1, 182 n.32.

225. In earlier, unpublished work, Vogel reported that an unusually large proportion of those charged with drunkenness pled guilty between 1860 and 1890 and that in 1880 they won greater concessions in exchange for their guilty pleas than did defendants charged with other crimes. See Vogel, supra note 146, at 155. As I will note shortly, see infra note 236 and accompanying text, in more recent work Vogel finds no concessions for guilty pleas in drunkenness cases, albeit at an earlier period in the century.

226. In her most recent article, see Vogel, supra note 148, Vogel devotes little space to Ferdinand's 1992 book (which in turn seems to have onitted mention of Vogel's related 1988 dissertation).

227. Vogel, supra note 148, at 168.

228. Id. at 165 .

229. See id. at 165-66. 
broadened voting rights, "which made it likely that state response [to social unrest] would take a form attuned to sustaining the popular consent." ${ }^{230}$ The political elite resolved this tension, Vogel argues, through a pattern of "episodic leniency." 231 By rewarding guilty pleas with sentencing concessions, Boston's magistrates (appointed largely by the Whig powerholders ${ }^{232}$ could secure convictions while dispensing grace and thereby maintain order while winning the voters' consent.

It is an elegant theory, and Vogel richly details the social conflicts and political maneuverings of the day. Such factors no doubt influenced in some ways, great or small, the course of plea bargaining's rise, and at a few junctures in this study I will bring the role of social forces to bear. ${ }^{233}$ In my analysis, however, social forces always played an indirect role: They were important to the extent that they helped shape the powers or interests of courtroom actors. Vogel's analysis, in contrast, simply forgoes questions about the source of bargaining power and pursues the matter of interests only abstractly. More importantly, the claim of episodic leniency that undergirds her theory stands on very shaky evidence.

During the 1830s, 1840s, and perhaps 1850s, Vogel claims, the magistrates of Boston's police court dispensed leniency in exchange for guilty pleas and did so noticeably enough to help secure public consent in their law-enforcement mission. Vogel acknowledges one troublesome shortcoming in her evidence. Of the five types of cases she analyzesdrunkenness, common drunkard, nightwalking, larceny, and assault and battery-drunkenness cases were by far the most likely to end in guilty pleas. ${ }^{234}$ In 1830 , when guilty pleas accounted for only 19.1 percent of all pleas in larceny cases and 10.6 percent of all pleas in assault-and-battery cases, they accounted for a full three-quarters of all pleas in drunkenness cases. And although guilty pleas in larceny and assault-and-battery cases advanced notably in 1840,1850 , and 1860 , the highest rate observed in these cases never matched even the lowest rate observed in drunkenness cases. ${ }^{235}$

These facts pose difficulties for Vogel's theory of episodic leniency because, as she frankly allows, drunkenness defendants appear to have won

230. Id. at 200 .

231. Id. at 232-33.

232. See id. at $208,211$.

233. See, e.g., infra notes 532-547 and accompanying text (describing the role of industrialization in indirectly shaping judges' attitudes toward plea bargaining); infra notes 786815 (explaining how social reformers with a charitable agenda advanced the cause of public defenders' offices by arguing that these offices would advance plea bargaining-and how these predictions had a self-fulfilling quality).

234. I encountered relatively few drunkenness or common-drunkard cases in the courts of the middle tier. I saw none at all between 1789 and 1843. Only during 1900 and 1910 did drunkenness and common-drunkard cases together account for as many as $10 \%$ of the total.

235. See Vogel, supra note 148, at 179. 
no leniency in exchange for their guilty pleas. In fact, they seem to have suffered a penalty for pleading guilty, drawing heavier punishments than those convicted after trial. ${ }^{236}$ Faced with this discordant evidence, Vogel simply excises drunkenness cases from her theory of episodic leniency. She says it is more important to focus on "crimes against property and the person"-that is, on larceny and assault and battery-because the authorities who promoted the policy of episodic leniency were most concerned with "offenses [that] threatened the security of the goods, buildings, and facilities crucial for growth." ${ }^{237}$ But this excision depends on four implausible facts: first, that the authorities believed that both larceny and assault and battery threatened the security of goods and buildings more than did drunkenness and that drunkenness did so little or not at all; second, that the authorities did not regard drunkenness itself as a threat to economic growth; third, that episodic leniency resulted in more complete (as opposed to more popular) law enforcement than did the relative harshness shown to drunkenness defendants; and fourth, that the point of episodic leniency-to secure popular consent in law enforcement-was more effectively achieved by showing leniency to thieves and assailants than to accused drunks.

236. See id. at 185, 190-91. The lack of concessions is perhaps not surprising given the hopeless position of the typical accused drunk. Vogel reports that virtually all who refused to plead guilty and chose trial were convicted. See Vogel, supra note 148, at 181 (suggesting a 100\% conviction rate); Vogel, supra note 146, at 80 (same). Ferdinand reports that in the 12 years of Boston Police Court records he studied between 1826 and 1850 , the rate of not-guilty findings in drunkenness cases only once approached four percent of all cases and otherwise ranged between zero and two percent. See FERDINAND, supra note 121, at 63. A newspaper's comment decades later that drunkenness trials "take[], on an average, just one minute to try each" suggests how perfunctory the proceedings were. Municipal Court-Judge May, Boston DAILY GLOBE, Jan. 9. 1879 , at 1 .

Nursing no fond hope of acquittal after trial, therefore, and down and out and often without the means for a lawyer, those accused of drunkenness might well have pled guilty without any inducement from the magistrate. See Vogel, supra note 146, at 81 ("These acquittal rates appear very likely an important contributor to the high guilty plea rates for drunkenness ...."). Recall that Vogel was studying a non-jury cour, in which the defendant could better assess the likelihood of acquittal based on the court's past behavior.

A highly anecdotal account of court goings-on in Boston provided this description of a drunkenness guilty plea in the police court in the early 1850s:

[S]ometimes the clerk will read the complaint to [the defendants], and sometimes he

will omit it, simply holding the document in his hand, and saying to the prisoner:

"You was brought here for being drunk, last night! Was you drunk?"

If the prisoner says "Yes," the Clerk immediately adds, "The court find you

guilty, and sentence you to pay a fine of three dollars and costs, for want of which you stand committed."

BALl FENNER, RAISING THE VeIL; OR, SCENES IN THE COURTS 27 (Boston, James French \& Co. 1856). Robert Hampel's findings in the courts of Salem confirm some aspects of this account. He reports that the court tried $43.3 \%$ of drunkenness defendants on the day of arrest and notes that "drunks could not afford the legal machinations used by sellers to prevent conviction." HAMPEL, supra note 65 , at 152 .

237. Vogel, supra note 148, at 206; see also id. at 191 ("It is also true that [drunkenness. common-drunkard, and nightwalking] offenses had fewer direct consequences for 'the people's welfare' that was being shaped by economic growth."). 
Vogel's theory of episodic leniency meets an even larger empirical obstacle when she attempts to demonstrate its central claim-that the leniency shown to those who pled guilty in larceny and assault-and-battery cases was substantial enough to help win popular consent in law enforcement. Vogel claims that plea bargaining emerged in these cases in the 1830 s and 1840 s and that "concessions were most strikingly evident in 1840 and 1860." ${ }^{238}$ She seems to acknowledge that her argument must fail unless the pattern of leniency was striking enough for the public to notice. The following table reprints her analysis of sentencing concessions in the relevant years:

TABLE 2. OUtCOMES IN SELECTED CASE TYPES:

BOSTON POLICE COURT, 1840-1860

\begin{tabular}{|l|c|c|c|c|}
\hline & \multicolumn{2}{|c|}{ Larceny } & \multicolumn{2}{c|}{ Assault \& Battery } \\
& & & & \\
& Pled Guilty & Lost at Trial & Pled Guilty & Lost at Trial \\
\hline 1840 & & & & \\
\% Imprisoned & 80 & 70 & 0 & 7 \\
\hline \% Fined & 20 & 30 & 100 & 93 \\
\hline $\begin{array}{l}\text { Avg. Term of } \\
\text { Imprisonment }\end{array}$ & 3.5 & 4.0 & N/A & 6.0 \\
\hline Avg. Fine & $\$ 3.67$ & $\$ 4.58$ & $\$ 3.36$ & $\$ 3.54$ \\
\hline \multicolumn{1}{|c|}{1850} & & & & \\
\% Imprisoned & 31 & 38 & 11 & 18 \\
\hline \% Fined & 69 & 63 & 89 & 82 \\
\hline $\begin{array}{l}\text { Avg. Term of } \\
\text { Imprisonment }\end{array}$ & 2.4 & 2.5 & - & - \\
\hline Avg. Fine & $\$ 6.25$ & $\$ 6.33$ & $\$ 4.71$ & $\$ 3.63$ \\
\hline \hline \multicolumn{1}{|l}{ 1860 } & & & & \\
\% Imprisoned & 36 & 38 & 9 & 14 \\
\hline \% Fined & 64 & 62 & 91 & 86 \\
\hline $\begin{array}{l}\text { Avg. Term of } \\
\text { Imprisonment }\end{array}$ & 4.0 & 2.5 & 2.0 & 3.5 \\
\hline Avg. Fine & $\$ 4.67$ & $\$ 9.71$ & $\$ 6.20$ & $\$ 4.46$ \\
\hline
\end{tabular}

Source: Mary E. Vogel, The Social Origins of Plea Bargaining: Conflict and the Law in the Process of State Formation, 1830-1860, 33 L. \& Soc'Y REv. 161, 184, 189 (1999). 
The table compares the fates of those who pled guilty and those who were found guilty after trial along three dimensions: the likelihood of imprisonment versus fine, the length of any confinement, and the size of any fine. ${ }^{239}$ The table indeed shows a pattern of lower penalties for those who pled guilty in larceny and assault-and-battery cases: Across eighteen points of comparison (three years times two crimes times three sentencing variables), the results suggest leniency for guilty pleas in twelve instances and a premium in only four. But the benefits of pleading guilty were very small. On average-across crimes and across years, weighing each cell in the diagram equally - a guilty plea reduced the defendant's chances of going to prison from thirty-one percent to twenty-eight percent; reduced the average term of imprisonment from 3.7 to 3.0 months; and reduced the average fine from $\$ 5.38$ to $\$ 4.81 .{ }^{240}$ Because serious offenders might have been more likely to choose trial than were less serious offenders (a possibility Vogel allows), ${ }^{241}$ the small margin of leniency shown here might reflect the relative seriousness of offenses rather than a reward for pleading guilty. In any event, absent evidence of episodic leniency more perceptible to the public, Vogel's arguments about its significance in explaining plea bargaining's rise appear to be moot.

I will, however, pursue one branch of Vogel's analysis further, both because other scholars have echoed the point and because it has a certain intuitive appeal. Plea bargaining arose in part, Vogel argues, because the voting public liked it. Its familiarity and accessibility won it support:

The plea bargain, in its customary simplicity, was more knowable (or 'cognoscible' in Bentham's term) than the arcana of common law-and so drew citizens into a relationship with a comprehensible state by clarifying what the law proscribed, the

239. Vogel claims a significant role for another form of concession-the decision to retain a case in the police court rather than transfer it to the municipal court, where penalties perhaps were greater. See id. at 193. But Vogel provides no evidence as to how the decision to transfer a case was reached-whether it was at the discretion of the court or of the defendant herself or was reached automatically based on the crime charged or the sentence awarded in the police court. The only evidence she provides on the question is Barbara Hobson's argument that prostitution defendants preferred resolution of their cases in the municipal court, where they thought they could strike more favorable deals. See id. at 191 n.42. Because Vogel conducted her research only in the police court, she cannot tell us if defendants whose cases were resolved before the municipal court indeed fared worse. Moreover, she provides no evidence that the public was aware of whatever significance such transfers had, and public awareness is essential to her theory of episodic leniency.

240. Even if we focus on the two years in which, Vogel says, "[c]oncessions were most strikingly evident" -1840 and 1860-the concessions seem small. In these two years, pleading guilty to larceny or assault and battery reduced the chances of going to prison from $32 \%$ to $31 \%$; reduced the average term of imprisonment from 4.0 to 3.2 months; and reduced the average fine from $\$ 5.57$ to $\$ 4.48$. See id. at $184,189,195$.

241. See id. at 185 n.34. Although Vogel refers here to the reluctance of repeat offenders to plead guilty, the point may apply to more serious offenders, whether or not they had a record. 
menu of costs associated with any breach, and facilitating a grasp of the consequences of those actions. ${ }^{2.2}$

In their study of the rise of guilty pleas in New York, Mike McConville and Chester Mirsky likewise point to the political popularity of plea bargaining as a factor in explaining its growth. They write that plea bargaining "avoided the discontent that imprisonment for convictions of the full indictment would engender among the immigrant underclass, who, under the movement for universal suffrage, had become part of the newly formed electorate." 243

Such arguments about plea bargaining's popularity of course demand evidence that the public knew about plea bargaining. Though McConville and Mirsky do not undertake such proof, Vogel does, and she points specifically to three signs of public awareness. First is a phenomenon Vogel terms "mirroring": If criminal defendants more readily pled guilty when authorities more readily granted concessions in exchange-that is, if defendants "mirrored" concessions with guilty pleas-then "members of the public [must have been] aware of concessions being granted." 2t4 Of course, evidence of mirroring speaks only to defendants' knowledge of concessions granted for pleas, and defendants may have known much more about plea bargaining than the public at large. But more fundamentally, Vogel's evidence of mirroring is vanishingly thin, consisting only of this (slightly simplified) table: $:^{245}$

TABle 3. GuIlty Pleas and Concessions:

BOSTON POLICE COURT, 1840-1860

\begin{tabular}{|c|c|c|c|c|}
\hline \multirow{4}{*}{ Year } & \multicolumn{2}{|c|}{ Larceny } & \multicolumn{2}{c|}{ Assault \& Battery } \\
\cline { 2 - 5 } & $\begin{array}{c}\text { \# of Types of } \\
\text { Concessions }\end{array}$ & $\begin{array}{c}\text { Guilty Plea } \\
\text { Rate }\end{array}$ & $\begin{array}{c}\text { \# of Types of } \\
\text { Concessions }\end{array}$ & $\begin{array}{c}\text { Guilty Plea } \\
\text { Rate }\end{array}$ \\
\hline 1840 & 4 & 0.20 & 3 & 0.00 \\
\hline 1850 & 1 & 0.14 & 2 & 0.12 \\
\hline 1860 & 2 & 0.50 & 3 & 0.41 \\
\hline
\end{tabular}

Source: Mary E. Vogel, The Social Origins of Plea Bargaining: Conflict and the Law in the Process of State Formation, 1830-1860, 33 L. \& Soc'Y REv. 161, 195 tbl.13 (1999).

242. Id. at 234; see also id. at 235-36 (repeating the claim that plea bargaining was "cognoscible").

243. Mike McConville \& Chester Mirsky, The Rise of Guilty Pleas: New York. 1800-1865, 22 J.L. \& SoC'Y 443, 466 (1995).

244. Vogel, supra note 148 , at 194.

245. Vogel's version of the table identifies the various concessions, though not their frequency or size. See id. at 195 . I do not believe this additional complexity increases the strength of her evidence. 
Vogel does not explain this table beyond stating generally that "fluctuations in concessions are mirrored, for some offenses, by parallel shifts in the tendency to plead guilty." 246 Without her aid, it is very hard to discern here a pattern of increasing guilty pleas responding to more liberally granted concessions.

Next, Vogel points to a monograph of court vignettes published in 1837 by the court reporter of the Boston Morning Post. ${ }^{247}$ "While not making too much of it," she notes that the reporter used the term "bargain" to describe the practice we know as plea bargaining, and she suggests that this usage reflects a public awareness of the practice. ${ }^{248} I$ have read through this 250 page volume with some care and have come across only three uses of the term "bargain." Two of these concerned merchandise sales. ${ }^{249}$ In the third, the reporter wrapped up his account of an assault-and-battery case with these words: "After the case was proved against Toupet beyond all hope of defence, he retracted his plea of not guilty, paid a fine of $\$ 5,00$ and costs, and departed pretty well satisfied with his end of the bargain." 250 Not only does the reporter's use of the idiom, "his end of the bargain," fall far short of proof that the notion of a plea bargain was abroad in the community, but the timing of the defendant's plea-apparently after the government had put in its case at trial-removes this case far from the mainstream of plea bargains.

Finally, citing only the legislature's report on its 1845 investigation into Asahel Huntington's charge-bargaining practices, Vogel claims that "public knowledge" of the use of plea bargaining to advance public policy "was widespread and the practice met with public approval." 251 Vogel is surely right that the Huntington inquiry did not escape public notice. But the only hint in the legislative record that the public (as opposed to the legislature) knew about Huntington's charge-bargaining practices was this highly partisan and apparently unpublished claim made in 1844 by Representative Cyrus Washburn, who first lodged the legislative complaint against Asahel Huntington for plea bargaining:

[T] current report among a large portion of the People of this Commonwealth that Asahel Huntington ... is and has been guilty of malpractice... by receiving of Defendants in cases of

246. Id. at 194.

247. See SELECTIONS FROM THE COURT REPORTS ORIGINALLY PUBLISHED IN THE BOSTON MORNING POST, FROM 1834 TO 1837 (Arno Press reprint 1974) (1837) [hereinafter SELECTIONS].

248. Vogel, supra note 148, at 194-95. Vogel twice notes Gill's use of this word, but neither time cites a page. See id.; Vogel, supra note 146, at 85.

249. See SELECTIONS, supra note 247 , at $78,171$.

250. Id. at 41 .

251. Vogel, supra note 148, at 206. 
prosecutions of Commonwealth against violators of laws regulating the sale of spirituous liquors, and others, sums of money much less than that which the statute laws fix[] ... and thereby discharging the said Defendants in his own responsibility without a trial . ...252

Washburn almost certainly overstated the public's "common \& current" attention to Huntington's plea bargaining. Perhaps he spoke from his bias against Huntington, or perhaps he spoke as an Essex County lawyer ${ }^{253}$ in whose small circle Huntington's doings loomed large. In any event, Washburn's claim does not square with news accounts of the Huntington affair, which seem to have avoided the topic of plea bargaining almost entirely.

The Lowell Daily Courier, one of the most important surviving Middlesex County newspapers, ${ }^{254}$ devoted considerable attention to the Huntington story, but made only the merest mention of plea bargaining. "Wonders will never cease," began the first of at least nine separate news items, six of them substantial, that the Courier devoted to the Huntington affair. ${ }^{255}$ "Who would have thought yesterday that the subject under discussion in the House to-day would have been upon a grave charge of official misconduct against the able and distinguished District Attorney...." The author said nothing of the charges themselves, however, though he assured his readers that they would "if true... seriously affect [Huntington's] standing in the community." Another item on the same page summarized the charges in such a way that the more sensational charge of corruption simply swallowed up any reference to plea bargaining: Washburn had charged Huntington "with malpractice in relation to the law granting licenses for retailing spirituous liquors, receiving money from prosecutions, from various individuals, and not accounting for the same, or paying the same into the Treasury of the Commonwealth, thereby defrauding the Commonwealth." ${ }^{27}$ A few days

252. ORDER FOR COMMTTTEE OF ASAHEL HUNTINGTON: REPORT, H. DOC. NO. 1499, at 2 (Mass. 1844) (on file with the Massachusetts Archives).

253. The committee's report identifies Washburn as an "Esquire" from Lynn, a town in Essex County, which was within Huntington's jurisdiction. See CASE OF ASAHEl Hunturgton: REPORT, H. DOC. No. 4, at 3 (Mass. 1845).

254. The Courier claimed to have the largest circulation of any paper printed in Lowell. See The List of Letters, LOWELL DAIL Y COURIER, SepL 30, 1845, at 2.

255. Letters from the Editor.-No. 7, LOWEL DAllY COURIER, Jan. 20. 1844, at 2; see also The District Attomey, LOWELl DAll Y COURIER, July 13, 1844, at 2 (reprinting an article from the Salem Register); District Aftomey Huntington, LOWELl DAll Y COURIER. Dec. 26. 1844, at 2; House, LOWEll DaIly COURIER, Jan. 9, 1845, at 2 (brief notice); In the House, Lowell DaIly COURIER, Mar. 14, 1844, at 2 (brief notice); In the Senate, LOWEl DAlL Y COURIER. Jan. 20. 1844, at 2; Letters from the Editor.-No. 6, supra note 142; Massachuserts Legislature, Loweu. DAllY COURIER, Mar. 16, 1844, at 2 (brief notice); Singular Proceedings, LowEll Dall Y COURIER, Jan. 23, 1844, at 2.

256. Letters from the Editor.-No. 7, supra note 255.

257. In the Senate, supra note 255. 
later the Courier reprinted the Salem Register's condemnation of Washburn's "grave accusations of official misconduct," 258 yet again made no reference to plea bargaining. Months passed with only two tiny references to the matter ${ }^{259}$ before the Courier reprinted another attack by the Register on the "miserable, skulking and groundless" charges against Huntington, sustained by testimony that "would not convict a dog." 260 Though the paper noted that Huntington had "submitted a few remarks in explanation of his course," it again said not a word about plea bargaining. ${ }^{261}$

Finally, in its third-to-last notice of the affair and almost a year after the first, the Courier for the first and last time mentioned what is for us the real object of concern. In an article devoted not to the legislature's inquiry but to a related grand jury proceeding, a single sentence appears near the bottom: "These complaints, it is well known, refer to the compromises made by $\mathrm{Mr}$. Huntington with the liquor-sellers, by which they paid sums of money to the Commonwealth in order to be relieved from their indictments." 262 Perhaps indeed these charges were "well known," but the balance of the evidence suggests otherwise. Each of the other news items referred in hushed tones to scandalous allegations of graft, very much unlike this matter-of-fact mention of Huntington's self-acknowledged dealings with liquor merchants. Less than three weeks later, when the Courier printed its last account of the legislature's investigation, it once again dismissed the charges as lacking "any foundation in fact" and as a mere "malicious attempt to injure the character and usefulness of one of the worthiest and best men in the State" and once again made no reference to plea bargaining. ${ }^{263}$

If we back away for a moment from the Huntington affair and search more generally, we find almost no evidence of public awareness of plea bargaining. I have cast a very broad net-topically, chronologically, geographically-in search of public notices about plea bargaining and related practices. In an extensive newspaper search that skipped across the century and focused in particular on the 1830 s and 1840 s-a period that Vogel, Ferdinand, and I all agree to be critical-I found no prominent mention of plea bargaining before District Attorney Albert Nelson's 1847 announcement of his pleading terms. ${ }^{264}$ There was, it is true, the occasional

258. Singular Proceedings, supra note 255.

259. See In the House, supra note 255; Massachusetts Legislature, supra note 255.

260. The District Attorney, supra note 255.

261. Id.

262. District Attorney Huntington, supra note 255.

263. Letters from the Editor.-No. 6, supra note 142.

264. Nineteenth-century newspapers are not generally indexed, so the task of surveying the century's newspapers for signs of public awareness of plea bargaining was quite labor-intensive. Several of my research assistants scrolled through dozens of reels of microfilmed newspapers and 
bit of courthouse news that said almost in passing that a slate of liquor defendants had "submitted, and paid their fines and costs." 205 But there was little to suggest that the public had a real awareness of plea bargaining. Nor was the Nelson notice the first of many pointed references. On the contrary, it was one of astonishingly few that I found in print anywhere in the nineteenth century outside of court reporters and legislative documents. ${ }^{266}$ Nor have I ever, in any nineteenth-century source, seen the term "plea bargaining." Even when I have looked specifically for commentary about particularly notable events in our story, I have found nothing of note. For example, although the Lowell Journal reported extensively on Barney Goulding's killing of his wife in Lowell in $1848,{ }^{267}$ it apparently ignored

made copies of all news items that touched on any of the topics relevant to this study. The search focused on Middlesex County, but included as well many newspapers from outside the county. As a survey of the entire century was impossible, I focused the students' efforts on time spans critical to different parts of this history. The students' efforts produced about 2200 photocopied pages, which I have read and incorporated here. The newspapers studied include:

\begin{tabular}{|l|l|}
\hline Boston Commonwealth & 1889 (whole year) \\
\hline Boston Evening Transcript & $\begin{array}{l}\text { Jan.-Oct. } 1880 \\
\text { Jan. 1885 } \\
\text { Jan.-Feb. } 1890 \\
\text { Jan.-Mar. 1895 }\end{array}$ \\
\hline Boston Globe & Jan.-May 1879 \\
\hline Cambridge Herald & Jan.-Mar. 1848 \\
\hline Cambridge Owl & Apr.-Oct 1848 \\
\hline Cambridge Palladium & Jan.-May 1843 \\
\hline Cambridge Tribune & 1882 -early 1885 (whole ycars) \\
\hline Lowell Courier/Daily Courier & $\begin{array}{l}\text { June 1835-1838: 1840-1842 } \\
\text { (whole years): 1843-1845 } \\
\text { (selected times) }\end{array}$ \\
\hline Lowell Journal & $\begin{array}{l}1847 \text { (whole ycar) } \\
\text { 1848 (most of year) }\end{array}$ \\
\hline Salem Gazette & Jan.-Aug. 1837 \\
\hline Springfield Daily Republican & Jan. 1865-May 1866 \\
\hline $\begin{array}{l}\text { Voice of Industry/New Era of } \\
\text { Industry (Lowell) }\end{array}$ & May 1845-Aug. 1848 \\
\hline \hline
\end{tabular}

My research assistants conducted a similar page-by-page search of various 19th-century law journals.

265. LOWELl COURIER, Sept. 19, 1837, at 2 (“We understand... that nearly all the individuals indicted at the June Term, for breach of the license law, have submitted, and paid their fines and costs."); see also SALEM GAZETTE, Dec. 27, 1836, at 3 ("Several others ... who were indicted for breaches of the License Law, came into Court, and pleaded that they would not contend with the Commonwealth; and agreed not to sell any more spirits.").

266. Among these few are repeated references made by the Boston Globe's court reporter during the last quarter of the century to plea bargaining in drunkenness cases. It appears that the regularity with which accused drunks pled guilty and paid a standard three-dollar fine had become somewhat of a public joke. See, e.g., Municipal Court-Judge May, Boston DAlly GLOBE, Apr. 4,1879 , at 1 ("All the [drunkenness defendants] exhibited a commendable resignation, and took their little fine of $\$ 3$ and costs in a beautiful and touching way."): Afunicipal Court-Parmenter, J., BOSTON DAILY GLOBE, Mar. 19, 1879, at 1 ("Eleven simple drunks compounded for their sins on the ordinary terms."). 
altogether his guilty plea and sentencing, yet Goulding's may have been the first plea-bargained murder case in Middlesex history.

In fact, the blinkered reporting of the Huntington episode highlights what might seem at first to be an odd incongruity in my evidence: Even while the public remained largely uninformed about plea bargaining in the courts, legislators not only knew about it, but acted on it-investigating Huntington's handling of liquor cases in 1844, barring prosecutorial nol prosses in 1852, and, as we will see, ${ }^{268}$ forbidding the filing of liquor cases in 1865. Perhaps one explanation is that many of the legislators-including Cyrus Washburn, who first complained against Huntington-were lawyers and therefore were unusually aware of goings-on in court. Another explanation may be that newspaper editors thought the public would not much care about plea bargaining even if legislators did. But the most likely explanation is that legislative attention to plea bargaining simply was incidental to its concern with liquor-law enforcement, probably the most enduring political issue in nineteenth-century Massachusetts. After all, the temperance movement, unlike plea bargaining, prompted substantial news pieces-sometimes whole columns long-in almost every issue of almost every newspaper. ${ }^{269}$ And even as the legislature took up the problem of plea bargaining in liquor cases three different times, it apparently took no notice of plea bargaining in murder cases, although almost half of all murder prosecutions in the $1860 \mathrm{~s}$ ended in clear plea bargains. The public surely was concerned about liquor-law enforcement. It simply did not know as much about the mechanics of that enforcement as did its elected representatives.

Difficult as it is to find evidence of public awareness of plea bargaining, it is even harder to find evidence that the public thought well of the practice. Yet Vogel's theory, like McConville and Mirsky's, depends on the public's approval of plea bargaining. I have found some evidence of disapproval of practices related to plea bargaining. In 1841, the Courier called it " a very miserable piece of business" when a Boston constable let a thief go in exchange for information about where he had hidden the goods. ${ }^{270}$ Others apparently agreed, for the constable was indicted for breach of duty. ${ }^{271}$ In 1866, a Boston newspaper took to task those crime

267. See Coroner's Inquisition, LowELL J., Mar. 24, 1848, at 4; Examination of Barney Goulding on the Charge of Murdering His Wife, LOWELL J., Mar. 31, 1848, at 1; Police Court. LOWELL J., Mar. 31, 1848, at 1.

268. See infra notes 280-282 and accompanying text.

269. Between Monday, October 13, and Friday, October 17, 1845, the Courier printed at least five substantial items on temperance, two of which were a full column or almost that in length.

270. Midnight Robber Arrested, LOWELL COURIER, Apr. 3, 1841, at 2. The newspaper added that the result "was not satisfactory to many people." Id.

271. See LOWELl CoURIER, Apr. 10, 1841, at 2. The constable was fined $\$ 50$ and costs. See LOWELL COURIER, July 3, 1841, at 2. Roger Lane reports, on the basis of other sources, that 
victims who compromised with criminals for return of their propenty. ${ }^{2 m}$ These practices were not plea bargains, however, because the defendants never pled, and the court never passed judgment. And in New York, where McConville and Mirsky base their claim of the electoral benefits of plea bargaining, the practice's press was bad. In 1865, the New York Times denounced plea bargaining by the local prosecutor's office, especially in crimes of violence, and suggested plea bargaining was to blame for the city's high crime rate. ${ }^{273}$

In defense of Vogel's and McConville and Mirsky's theories, one might argue that plea bargaining could have won votes even without a broad public audience if individual defendants left court gratified by their bargains and prepared to vote or to influence others who would. I have come across scattered evidence that defendants reacted-or were thought to react-in this way, though the earliest I have found is from New York and is dated $1869 .{ }^{274}$ In any event, while such a theory about satisfied judicial customers might explain the leniency that Vogel claims to see in Boston's police court, it does far less well when applied to the charge-bargaining practices I found in liquor cases in Middlesex County. It is hard to believe that the liquor-license defendants, whom Huntington or Train snagged with one of their multi-count indictment forms and who submitted to one or more charges to escape the full force of the district attorney's volley, left court eager to throw him their support. Nor is it likely that the district

"there was no outcry" about the constable's actions. ROGER LANE, POLICING THE CITY: BOSTON 1822-1885, at 57 (1967). He adds that "[t]he commonwealth also offered rewards, several of which went to [the constable]." Id. at 259 n.57. The statutes Lane cites for support, however, have no relation to the case. See id.

272. See Compromising Crime, DAIl Y Evening TRAveller (Boston), Apr. 12, 1866, at 1 ("This is all wrong,-wrong in itself, and wrong because it operates as an encouragement to crime, and a discouragement to industry, and as a weakener of the rights of property.").

273. It is a growing custom with the District-Attomey to accept a plea of guilty of a minor offense from a party indicted for a high crime. ... We cease to be startled at the frightful record of bloody affrays or violent robberies which the daily papers present, when we see that criminals seldom receive the punishment due to their crimes, but are let loose to tell their comrades how easy it is to escape justice in NewYork.

Crime and Criminals, Law and Justice in New-York, N.Y. TIMES, Jan. 7. 1865, al 4: see also Eric H. Monkkonen, The American State from the Bottom Up: Of Homicides and Courts, 24 L. \& SOC'Y REV. 521, 529 (1990) (quoting a similar sentiment in a New York Times cditorial of 1866); The O'Hara Tragedy, N.Y. TMMES, Apr. 22, 1873, at 5 (recounting an apparent charge bargain in a murder case).

274. In 1869, the New York Times suggested that indicted defendants whom the district attorney never prosecuted might become political assets: " They naturally feel grateful for this forbearance, and depraved though they may be, appreciating the purity of [the district attomey's] motives, testify their gratitude by working for him at elections." WWLUR R. MULER. COPS AND BOBBIES: POLICE AUTHORITY IN NEW YORK AND LONDON, 1830-1870, at 79 (1977) (quoting from the New York Times); see also Justin Miller. The Compromise of Criminal Cases. 1 S. CAL. L. REV. 1, 4-5 n.16 (1927) ("It seems to be a customary practice of winning favor with constituents to save them from the consequences of their illegal acts ...." (quoting THE REPORT OF THE GOVERNOR'S COMMITIEE ON MOTOR TRAFFl, H. DOC. No. 1737 (Mass. 1924), reprinted in MASS. L.Q., July 1924, at 1, 10)). 
attorney would have traded the goodwill of the defendant's law-abiding neighbors, who regarded their local speakeasy merchants as pests, ${ }^{275}$ to gain the uncertain and tainted support of the barkeeps he hauled into courteven if cynical observers occasionally suggested this was his purpose. ${ }^{276} \mathrm{~A}$ district attorney who wished to curry favor with a potential liquor defendant had a better route-both milder and quieter-than to bring public charges and then plead them away: He could contrive to avoid an indictment. In 1843 , for example, when confronted with the demands of angry neighbors that he prosecute a local selectman who dealt liquor for his bread, Huntington dutifully summoned a flock of witnesses before the grand jury, but the grand jury declined to indict. ${ }^{277}$

The theory that plea bargaining was politically popular suffers not only from a lack of evidence that plea bargaining garnered political support, but

275. See infra note 277 and accompanying text.

276. In 1885, a Boston newspaper printed the complaint of a temperance advocate that "the district attorney is omnipotent and need not prosecute any liquor dealer ... if the defendant can control a few votes." Massachusetts Temperance Alliance, BOSTON EvENING TRANSCRIPT, Jan. 7,1885 , at 8 . After suggesting that the district attorney was cutting deals using the on-file method of plea bargaining, the writer continued, "District attorney Stevens is efficient against the friendless, unefficient among politicians." $I d$.

277. In January 1843, Huntington received the following letter:

Dear Sir,

I wish to trouble you once more with complaints respecting the Licence Laws; we have now a hard case the chairman of our Board of Select men Capt. Moses Phipps, has a store in the south part of this town where ardent spirit is continually being sold without licence, $\&$ it is quite a source of annoyance to the neighbourhood \& they have requested me to communicate with you upon the subject.

This may well be termed spirit-ual wickedness in high places. Mr. Phipps is a man of property $\&$ influence, but his influence is not always for good, he was once indicted for selling without licence $\&$ it cost him something, but that did not make him obedient. \& people think it time to try him once more.

I have been furnished with a long list of witnesses, \& you will do well perhaps to summon them all, some are the buyers \& drinkers, \& some are those who have scen it put up for them; I know not the tenor of their testimony but it is said that people buy by the glass \& drink at the store, or by the quantity to carry away. . .

Please keep my name out of sight, \& oblige:

Yours truly,

John A. Fitch

Letter from John A. Fitch to Asahel Huntington (Jan. 11, 1843) (on file with the Massachusctts Archives, contained in Commonwealth v. Moses Phipps \& Benjamin Phipps. Middlesex Ct. C.P. File Papers (June 1843)). Huntington indeed issued subpoenas to most or all of the witnesses Fitch named, and eight of them testified before the grand jury, which nonetheless returned a no bill. See Phipps \& Phipps, Middlesex Ct. C.P. File Papers.

I have no evidence that a grand jury of the 1840s "would indict a ham sandwich." See SOL, WACHTLER, AFTER THE MADNESS: A JUDGE's OWN PRISON MEMOIR 292 (1997) (claiming credit for one version of the famous quip). But at least as early as 1893 , we can find complaints that "the grand jury is, in practice, mere clay in the hands of the prosecuting officer." Heman W. Chaplin, Reform in Criminal Procedure, 7 HARV. L. REV. 189, 191 (1893). It is interesting that another of the very few cases I have noticed in which citizens asked the district attorney to takc action against a local liquor dealer also ended in a no bill. See Commonwealth v. Manley Richardson, Middlesex Ct. C.P. File Papers (June 1843) (on file with the Massachusetts Archives) (containing a letter of complaint and a list of witnesses bearing on the rum-selling activitics of a local innkeeper as well as documents suggesting that six witnesses testified before the grand jury). 
also from solid contrary evidence that those who most needed political support did what they could to kill plea bargaining in liquor cases. The office of district attomey became elective only in $1856 .{ }^{278}$ Yet even as unelected district attorneys perfected multi-count liquor-indictment forms as plea-bargaining tools, elected legislators contrived to frustrate their use. In 1852, as we have seen, the legislature effectively halted charge bargaining in liquor cases by banning nol prosses except with the approval of the court. There is little reason to think that the legislature acted without the specific intent to kill prosecutorial plea bargaining. Although I have not found reference to this part of the law in the surviving legislative records, we can gather something of the legislature's intent from its persistence in maintaining the nol pros ban in its 1855 and 1869 reenactments of the prohibition law, ${ }^{279}$ long after it was clear that the ban had snuffed out prosecutorial charge bargaining of the pre-1852 variety.

We find clearer proof of the legislature's distaste for prosecutorial plea bargaining in the steps it took to kill the one form of prosecutorial plea bargaining in liquor cases that survived the 1852 law. In 1865, after a series of witnesses disclosed to a legislative committee that prosecutors were placing cases on file to get around the nol pros ban, ${ }^{280}$ the legislature promptly passed "An Act To Prevent Evasions of the Provisions of Section Fifty-Eight of the Eighty-Sixth Chapter of the General Statutes" - that is, evasions of the section of the liquor law that banned prosecutorial nol prosses. The new law provided that no liquor case "shall be laid on file or disposed of except by trial" without the court's approval. ${ }^{281}$ Thereafter, the legislature remained vigilant, reenacting its bar against filing liquor cases in 1869 and $1885^{282}$ and in general, throughout the nineteenth century,

278. See Act of May 16, 1856, ch. 173, § 1. 1856 Mass. Acts 98, 98-99 (conceming the election of district attomeys and other county officers). The office of attomey general apparently became elective in 1855, see MASs. CONST. an. XVII (ratified May 23. 1855), though Davis put the date at 1858 , see 1 DAVIS, supra note 14 , at 290.

279. See Act of June 19, 1869, ch. $415, \S 60,1869$ Mass. Acts 706, 723 (" [T] pe prosecuting officer... shall not enter a nolle prosequi [in any case arising under this act] except with the concurrence of the court."); Act of Apr. 20, 1855, ch. 215, $\$ 35,1855$ Mass. Acts 623, 641 (" [A] nolle prosequi shall not be entered by the prosecuting officer [in any case arising under this act]. excepting with the concurrence of the couri."). The 1855 reenactment followed a decision by the Supreme Judicial Court in 1854 declaring unconstitutional certain search-and-scizure provisions of the 1852 prohibition law. See Fisher v. McGirr, 67 Mass. (1 Gray) 1, 21 (1854).

280. See infra notes 330-332 and accompanying text.

281. Act of May 12, 1865, ch. 223, $\$ 1,1865$ Mass. Acts 617.617.

282. See Act of June 19, 1885, ch. 359, $\$ 1,1885$ Mass. Acts 817,817 (providing that * [n]o case in court for the violation of ... any . . . act . . . relating to intoxicating liquors shall be placed on file or disposed of, except by trial," except with the court's concurrence): Act of June 19. 1869 , ch. $415, \S 60,1869$ Mass. Acts 706, 723-24 (providing that "[n]o case in court for the violation of ... this act ... shall be laid on file or disposed of except by trial." except with the concurrence of the court). 
preventing prosecutors from contriving plea bargains without judicial participation. ${ }^{283}$

Although Vogel cannot sustain her claim that plea bargaining in Massachusetts was politically popular, she does point to another political mechanism that may have moved Massachusetts prosecutors to plea bargain when they could. In 1832 the legislature first required local prosecutors to report the outcomes of their cases. Vogel surmises, no doubt rightly, that each prosecutor hoped to appear as successful as his peers-a hope made more urgent when the office became elective in $1856 .{ }^{284}$ In 1844 District Attorney John $\mathrm{H}$. Clifford of the southern district, who went on to become attorney general and governor, made a point of telling the legislature that he had handled 523 cases in the previous year and that "[ $t]$ he number of acquittals by the verdicts of juries [was just] four." ${ }^{285}$ Neither here nor in a similar boast made elsewhere ${ }^{286}$ did Clifford trouble his audience with the

283. The 1852 ban on nol prosses, reenacted in 1855 , as well as the 1865 ban on putting cases on file, remained in place until both were repealed when the legislature briefly replaced the prohibition law with a license law in 1868. See Act of Apr. 30, 1868, ch. 141, § 26, 1868 Mass. Acts 107,115 . Both were reinstated in 1869 , when the state returned to a prohibition regime. See supra notes 279,282 . In 1875 , the state reverted to a license-law scheme, and both were repealed. See Act of Apr. 5, 1875, ch. 99, $\S 1-6,1875$ Mass. Acts 664; Act of Mar. 9, 1875, ch. 43, $\$ 1$. 1875 Mass. Acts 631,631 . When the legislature reinstated the ban on filing cases in 1885 , it made no direct reference to the prosecutor's nol pros power, but it did provide that no liquor case "shall be placed on file or disposed of, except by trial" without the court's concurrence, seemingly constraining the nol pros power as well. Act of June 19, 1885, ch. 359, § 1, 1885 Mass. Acts 817. 817 (emphasis added).

Hence, there were two periods between 1866 and the end of the century during which prosecutors apparently had the freedom to nol pros liquor cases or place them on file-from 1868 to 1869 and from 1875 to 1885 . But in both these periods, the goveming liquor law granted broad sentencing discretion to the judge. The 1868 law provided that "[a]ny person convicted of a violation of any of the provisions of this act, shall be punished by a fine not exceeding five hundred dollars, and confinement at hard labor in the house of correction not exceeding six months." Act of Apr. 30, 1868, ch. 141, § 18, 1868 Mass. Acts 107, 112. By giving judges such wide sentencing discretion, this law-like most penal provisions in Massachusetts-deprived prosecutors of the sentencing control that they needed to charge bargain effectively. The 1875 law, however, arguably opened a window for prosecutorial charge bargaining. It provided for a punishment of "a fine not less than fifty nor more than five hundred dollars, or imprisonment not less than one nor more than six months, or by both such fine and imprisonment." Act of Apr. 5 . 1875 , ch. $99, \S 13,1875$ Mass. Acts 664,668 . By establishing a minimum fine, this law might seem to have created an opportunity for prosecutors to bring multiple counts to gain leverage for a charge bargain. But it is unlikely the tactic would have worked without judicial participation. Most defendants would have been reluctant to plead guilty to a liquor offense that carried up to six months' imprisonment without some assurance from the judge that he would not impose time. And in fact, during the October 1880 term of court-the only term of court I studied closely while this statute was in effect-I observed no charge bargaining in liquor cases. I also observed none in the June 1885 term, when this law was just being abolished.

284. See Act of May 16, 1856, ch. 173, $\S 1,1856$ Mass. Acts 98, 98-99 (concerning the election of district attomeys and other county officers); Act of Mar. 14, 1832, ch. $130, \S 8,1832$ Mass. Acts 396, 403-04; Vogel, supra note 148, at 218-19; Vogel, supra note 146, at 136.

285. S. Doc. No. 68, at 7, 9 (Mass. 1844) (reprinting the letter of J.H. Clifford. Jan. 20, 1843 [sic]). Clifford became attomey general in 1849 and governor in 1852. See 1 DAvis, supra note 14 , at 290.

286. In Clifford's papers, there is a handwritten biography or autobiography presumably prepared for a run for office. At page six, it reports that "while there were from three to four 
number of trials he risked in amassing so striking a record of success. In fact, the same feature of county prosecutors' annual reports to the legislature that makes them almost useless to historians of plea bargaining made them supremely useful to prosecutors who aimed to impress-for these reports rarely distinguished between convictions after trial and convictions by plea. ${ }^{287}$

These reports, therefore, are not evidence of plea bargaining's political popularity, but of the opposite; not evidence of the public's awareness of plea bargaining, but of the opposite; and not evidence of the popularity of extending leniency to some criminal defendants, but of the opposite. ${ }^{288}$ That prosecutors seem to have found political advantage in reporting high conviction rates and in obscuring how they won them suggests that the public preferred severity to leniency and full convictions to bargained deals. These reports cannot support Vogel's or McConville and Mirsky's claims of broader social, cultural, or political forces at work in the rise of plea bargaining. They are instead evidence that individual prosecutors found a

hundred cases yearly, there were just seventeen verdicts of not guilty rendered in the district in criminal cases, during the entire decade over which his incumbency of the office extended." John H. Clifford Papers, 1845-1851 Box, Jan.-Oct. 1850 Folder (on file with the Massachusetts Historical Society). The biography attributes Clifford's success to his firm course of " abandoning a prosecution, when he became satisfied that the jury ought to enternin reasonable doubts of the guilt of the accused." Id.

287. The Massachusetts attomey general began making annual reports to the legislature in 1832. Except for an interruption when the office itself was suspended between 1843 and 1849. see supra note 129 and accompanying text, these reports appeared throughout the 19th century. Until 1870 they included abstracts of the business of the various district attorneys. From 1832 through 1859, these abstracts made no distinction between convictions after trial and convictions after plea. A single category, "Convictions," presumably included both phenomena See, e.g., S. DOC. No. 20, pt. 2, at 19-35 (Mass. 1842) (annual report of the attomey general). Between 1860 and 1869, however, the abstracts of the district attomeys' business took on far greater detail and, in particular, noted the number of guilty and no-contest pleas in each of the various calegories of crime. See, e.g., PUB. DOC. No. 23 app. at 22-26 (Mass. 1860) (annual repon of the altomey general for the year ending Dec. 31,1860 ). In 1870, this experiment with full disclosure stopped as suddenly as it had begun. Throughout the rest of the century. the reports of the altomeys general excluded altogether the abstracts of the district attomeys' business. See, e.g., PUB. Doc. No. 12 (Mass. 1871) (annual report of the attomey general for the year ending Dec. 31, 1870).

I have not found the reason for the great candor of the 1860 s. Four different men served as attorney general in that decade, and neither the beginning nor the end of the decade coincided with a change of office holders. See Lewis W. Morse, Historical Outline and Bibliography of Attomeys General Reports and Opinions from Their Beginning Through 1936, 30 L. LIBR. J. 39, 111-12 (1937).

288. In his original plea-bargaining expose, Raymond Moley complained of the ambiguity of prosecutors' reports:

What is much more important to the prosecutor is the fact that in such records as most prosecutors make of the work which they have performed, a plea of guilty of any sort is counted as a conviction, and when he goes before the volers for re-election he can talk in large terms about securing convictions when, in reality, these "convictions" include all sorts of compromises. . . .

The extent to which this actual, although not formal, misrepresentation of records is indulged in is indicated by the fact that in practically every state where there are any records at all, the convictions upon plea are lumped with convictions by jury.

Moley, supra note 47 , at 103 . 
personal and political advantage in securing the easy victories that plea bargaining afforded. For all that these reports suggest, prosecutors may have believed that the more clandestinely they could secure those victories. the better.

Now we must examine a form of plea bargaining more clandestine than the rest. On-file plea bargaining, which emerged sometime in the first half of the nineteenth century, was the only form of prosecutorial plea bargaining other than charge bargaining in murder cases to survive the legislature's mid-century assault on nol prosses in liquor cases. No longer able to charge bargain in liquor cases and lacking judicial support for the sort of broad-based sentence bargaining that would emerge later, prosecutors kept plea bargaining alive as an underground resistance movement sustained by their power to put cases quietly on file. In its relative secrecy, on-file plea bargaining belies Vogel's claims about the importance of political popularity in plea bargaining's rise. And in its versatility, on-file plea bargaining belies Ferdinand's claims about the victimless nature of liquor crimes and the sophistication of liquor defendants. These features perhaps made some cases more attractive targets for plea bargaining, but just as they were not sufficient to keep alive prosecutorial charge bargaining in liquor cases, so they were not necessary to successful on-file plea bargaining. For on-file plea bargaining never was limited to victimless cases or those cases that involved more savvy defendants. Rather, it spread throughout the lower reaches of the Massachusetts criminal docket.

\section{ON-File Plea Bargaining AND the Rise of Probation}

Prosecutorial charge bargaining in liquor cases died with the legislature's ban on unilateral prosecutorial nol prosses in 1852. Three years later, when the legislature reenacted alcohol prohibition, it turned the screws even tighter on liquor dealers by attaching a mandatory term of confinement to every offense under the act. ${ }^{289}$ The combined effect was that many more liquor cases went to trial. In 1849 , only eighteen of seventyeight liquor cases (or twenty-three percent) went to trial, as against fortythree out of 107 cases (or forty percent) in 1859. But what happened to the sixty-four liquor cases in 1859 that did not go to trial?

289. See Act of Apr. 20,1855 , ch. $215, \S 15,1855$ Mass. Acts 623,630 (calling for a $\$ 10$ fine and a 20 - to 30-day term for illegal sale, with mounting mandatory penalties for subsequent offenses); $i d . \$ 17,1855$ Mass. Acts at 631 (imposing a $\$ 50$ fine and a three-to-six-month term for being a common seller, with mounting mandatory penalties for later subsequent offenses); $i d$. $\S 24,1855$ Mass. Acts at 635 (imposing a $\$ 10$ fine and 20-day term for keeping liquor with the intent to sell). 
A citizen of Middlesex County who chose to investigate liquor-law enforcement in the courts in that year would have had difficulty even recognizing this as the proper question to ask. A careful review of the record book for the Superior Court and the Court of Common Pleas (the former court succeeded the latter in 1859$)^{290}$ would have disclosed only sixty-six liquor cases-forty that went to trial ${ }^{291}$ and twenty-six others that ended in guilty pleas (and prison terms) or nol prosses (approved by the court) or dismissals. But at various places in this handsome oversized volume, the citizen might have spied a cryptic heading: "The following Indictments \& Complaints ... the Attorney for the Commonwealth in this behalf orders on file." 292

The list that followed would not have resolved confusion-it was just a series of names without charges, case numbers, or places of origin. Hoping to find out more, the citizen might have turned in two directions. If the clerk of courts permitted inspection of the file papers for each case, the citizen would have found the charges as well the cases' progress through court, but the process of inspection would have been plodding. The alternative was to ask for access to the clerk's docket book. Unlike the record book, intended for both posterity and public inspection, ${ }^{393}$ the docket book apparently was for the clerk's eyes only - both the handwriting and the abbreviations ward off intruders. But with patience, the citizen would have found the answer: In addition to those sixty-six liquor cases clearly identified in the 1859 record book, there were another forty-one in the docket book, most listed simply as "L.L." 294 _and all but a few placed "on file." Mixed in with them were another 122 non-liquor cases, most similarly placed on file.

On the whole, the docket book does not disclose why these cases ended up on file, though an occasional note will advise that the "Deft. left" 295 or the principal witness has "gone west." ${ }^{296}$ But in fifteen liquor cases in

290. See supra note 5 .

291. Three of the tried cases did not appear in the record book, but only in the docket book.

292. See, e.g., Middlesex Ct. C.P. R. Book (Feb. 1859); Middlesex Super. Cl. R. Book 18 (Feb. 1859).

293. I draw this conclusion from the high quality of the volumes themselves and the obvious care taken in their preparation. It is not clear exactly when the record books were written in relation to each term of cour, but it is clear from both their neatness and their mode of organization that they were not produced in court as the business was ongoing. I think it is most likely that the clerk prepared the record book after each term of court.

294. The abbreviation was a throwback to the days before 1852. when the slate had a "license law" as opposed to full-scale alcohol prohibition, but now it signified simply "liquor law." Even in the docket books, the clerk maintained a distinction between violations of the prohibition law and violations of the liquor-nuisance statute. My discussion here is limited to the former, as the nuisance act carried neither the nol pros ban nor (at this time) mandatory prison. See supra note 176.

295. Commonwealth v. Bridgit Durgin. Middlesex Ct. C.P. Docket Book No. 817 (Feb. 1859).

296. Commonwealth v. Eldridge H. Spinney. Middlesex Ct. C.P. Docket Book No. 112 (Feb. 1859). 
1859, the book adds an important procedural detail-that before the case was put on file, the defendant had pled guilty. Hence, in Commonwealth $v$. Ann Donovan, ${ }^{297}$ the clerk wrote, "Plea in Court below retracted \& now pleads guilty. [O]n file." ${ }^{298}$ Donovan's case and others like it are the focus of my interest here. When I refer to the on-file mechanism, I mean those cases that were placed on file after the defendant's plea of guilty or no contest. In time, I will explain why I think this procedure deserves the name on-file plea bargaining.

Donovan's case bears no notation concerning either the mandatory fine or the mandatory prison term that conviction under the liquor law carried. Apparently, the act of placing the case on file stayed execution of the sentence. Although Donovan is silent about what happened from that point on, the record in other cases, including many non-liquor cases, adds more, as in this "misdemeanor" prosecution of James Quinlan and John Callahan: "Plea severally guilty-Callahan recogd. on file on probation." 299 Defendant Callahan apparently gave or promised the court an unspecified sum of money as surety for his future appearance or good behavior-that is, he "recog[nize]d" for his future good behavior-and was then placed on probation.

These are not the earliest cases to call to mind modern probation, nor did such cases emerge first in Middlesex County. As F.W. Grinnell argued many decades ago, ${ }^{300}$ the story of probation's rise should begin with the prosecution of Jerusha Chase in Boston in 1830-for Chase may be the first reported instance of the on-file mechanism at work. ${ }^{301}$ In February 1830 , Jerusha Chase appeared in the Boston Municipal Court to face a charge of stealing from a residence. The clerk recorded the result:

Feb. 8. Defendant retracts her [not guilty] plea and pleads guilty and recognized in the sum of two hundred dollars with Benjamin Salmon, trader, and Daniel Chase, Cordwainer of Marblehead, to come when sent for and in the meantime to keep the peace . . . ${ }^{302}$

The judge released Chase and charged her two sponsors-Benjamin Salmon and Daniel Chase-to guarantee her good behavior at risk of

297. Middlesex Ct. C.P. Docket Book No. 789 (Feb. 1859).

298. Id.

299. Commonwealth v. James Quinlan \& John Callahan, Middlesex Ct. C.P. Docket Book No. 664 (Feb. 1859).

300. See F.W. Grinnell, Probation as an Orthodox Common Law Practice in Massachusetts Prior to the Statutory System, MASs. L.Q. 591, 601-04, 610-12 (Aug. 1917).

301. See Commonwealth v. Jerusha Chase (Boston Mun. Ct. 1831), in Reports of Criminal Cases, Tried in the Municipal, Court of the City of Boston, Before Peter OXENBRIDGE THACHER 267 (Horatio Woodman ed., Boston, Little \& Brown 1845) [hereinafter REPORTS OF CRIMINAL CASES].

302. Grinnell, supra note 300 , at 604 (quoting from the court record). 
forfeiting $\$ 200$ should they fail. The case itself was placed "on file" (a fact recorded elsewhere) $)^{303}$ and would stay there as long as Chase remained on good behavior. Though Chase's conviction then lay dormant, the prosecutor had the power to revive it if Chase's behavior later turned worse.

I cannot say exactly when the procedure at work in Chase found its way into Middlesex County. Before 1844, the county's criminal docket books contained no information other than what appeared in the record books. The record books, as I noted earlier, never disclosed much about the on-file mechanism other than the fact of its existence, and before 1849, they did not disclose even that. ${ }^{304}$ If we therefore begin looking in the 1844 docket book, we find something very much like the on-file mechanism already vigorously in use. The docket book lists seventy-six cases in which the defendant pled either no contest or (occasionally) guilty. Although almost all of these involved violations of the liquor law that called for mandatory fines, the book notes no fines. Instead, it says that the cases were continued-and then continued again. Eventually, the district attorney nol prossed several of the cases, ${ }^{305}$ thereby canceling the fines.

The docket book for 1847 makes it clear that most such cases were destined to end in nol prosses. Twenty-four defendants pled either guilty or (occasionally) no contest to a violation of the liquor law in the February session of the Court of Common Pleas. All of these cases were continued to the June session and then again to the October session. At the October session, district attorney Albert Nelson nol prossed the whole slate of cases without demanding a single fine. Nelson's frequent use of this mechanism probably stemmed from his 1847 announcement promising that those liquor defendants who pled guilty at the next session of court would escape with no fine. ${ }^{306}$ That announcement had required that defendants "enter into

303. See Jerusha Chase, in REPORTS OF CRIMINAL CASES, supra note 301, at 267; Grinnell, supra note 300 , at 604 .

304. It appears that the record book for the June 1849 session of the Middlesex Court of Common Pleas was the first to list cases placed on file. See Middlesex Ct. C.P. R. Book 461 (June 1849).

305. See, e.g., Commonwealth v. Joseph Reed, Middlesex Ct. C.P. Dockct Book No. 78 (Oct. 1844) (noting that the defendant pled no contest to a liquor charge in February 1843, that the case had been continued until this session, and that the district allomey now nol prossed the case); Commonwealth v. Elias Messenger, Middlesex Ct. C.P. Docket Book No. 108 (Oct. 1843) (stating a similar chronology).

306. Nelson made this announcement before a cour session in Essex County, also par of his district, and not in Middlesex, but there is no reason to think that his practice that year would have varied greatly between the two counties. I have examined the records of the Essex Coun of Common Pleas for the June 1847 session-the next session after Nelson's announcement. The court's record book, unsurprisingly, makes no mention of eases handled in the way described above, and the court's docket book appears to be missing. The file papers for individual cases, however, have survived. I found 10 liquor cases in which the defendant pled guilty or (in two cases) no contest and then pledged or posted $\$ 200$ as security for his appearance in the future. No fines are noted. 
recognizance to observe the law." ${ }^{307}$ Although the Middlesex clerk rarely noted such recognizances in 1847, the clerk in Essex County, where Nelson also prosecuted, regularly did. ${ }^{308}$ And in one Essex liquor case from 1847 , opposite the clerk's notation that the defendant pled guilty, Nelson himself scrawled on the file papers, "Deft to be sentenced if he sells after Sept. 28 1847." 309

This procedure of permitting the defendant to plead to a liquor charge, continuing the case for two or more court sessions, and then ultimately entering a nol pros fell somewhat short of the true on-file mechanism. ${ }^{310}$ Placing a case on file continued it indefinitely ${ }^{311}$ and never called on the district attorney to exercise his nol pros powers. But this somewhat more primitive procedure resembled the on-file mechanism both in permitting defendants who had pled guilty or no contest to escape a mandatory penalty and in giving the district attorney some control over the defendant's future behavior.

By the end of 1847, the true "on file" system, so called, had arrived in Middlesex County, ${ }^{312}$ but it was rarely used. Two years later, during Charles Russell Train's second year in office, the on-file mechanism suddenly became a major and fairly regular component of the district attorney's work in Middlesex. In the June term of that year, Train placed 108 cases on file. In thirty-two of these, the defendant pled guilty or no contest before Train filed the case. Five liquor cases were placed on file after pleas, still falling

307. License Cases, supra note 79.

308. See, e.g., Commonwealth v. David Chandler, Essex Ct. C.P. File Papers No. 279 (June 1847) (on file with the Essex County Superior Court) (noting that the defendant, having pled guilty to a liquor indictment, pledged or posted $\$ 200$ to appear in the future and to keep the peace).

309. Commonwealth v. C. Robinson, Essex Ct. C.P. File Papers No. 394 (Dec. 1847) (on file with the Essex County Superior Court).

310. I found what might be a surprisingly early example of this mechanism at work in the earliest liquor case that my research turned up. In 1790, William Barker came before the Court of General Sessions of the Peace charged with a single unlicensed sale. He pled guilty and then, on his motion, the court suspended judgment until the next term of court. See Commonwealth v. William Barker, Middlesex Ct. Gen. Sess. Peace R. Book 4 (Sept. 1790). At the next termı, the court again deferred passing sentence. See Commonwealth v. William Barker, Middlesex Ct. Gen. Sess. Peace R. Book 16 (Nov. 1790). Finally, at the next term, the prosecutor who appeared on the case (probably appointed temporarily by the court), "by advice of the Court," nol prossed the case. See Commonwealth v. William Barker, Middlesex Ct. Gen. Sess. Peace R. Book 26 (Mar. 1791). Although it surely seems .possible that this chain of events manifested the same process that I have described at work in 1847 , I would be reluctant to claim too much of an isolated example-and I did not see this procedure repeated until the 1840s.

311. As the Supreme Judicial Court wrote decades later, ordering cases on file "dispenses with the necessity of entering formal continuances upon the dockets." Commonwealth $v$. Dowdican's Bail, 115 Mass. 133, 136 (1874).

312. See, e.g., Commonwealth v. David Wheeler, Middlesex Ct. C.P. Docket Book No. 921 (Oct. 1847) (recording that the defendant pled guilty to a liquor charge and entered into recognizance and that the case then was "[p]laced on file"); Commonwealth v. Bernhard Moosback, Middlesex Ct. C.P. Docket Book No. 862 (Oct. 1847) (noting the same facts regarding a larceny case and adding that the defendant was "used as witness"). 
short of the nine charge bargains Train conducted that same term in liquor cases. A striking total of twenty-seven non-liquor cases were placed on file after pleas, as against only two charge bargains. Most of these non-liquor cases involved crimes at the low end of the criminal ladder: There were eleven victimless sex offenses, three larcenies, three minor assault crimes, two nuisances, and one charge of obstructing an officer. A few crimes stood a rung or two higher: Four cases, all involving the same defendant, alleged counterfeiting, and one charged felonious assault. ${ }^{313}$ We should not be surprised at Train's sudden, aggressive use of the on-file mechanism. We saw earlier that his 1849 caseload was more than four times as great as Huntington's 1843 burden and that Train responded in part by wielding his power to charge bargain in liquor cases with even more zeal than his predecessors. ${ }^{314} \mathrm{~A}$ prosecutor who had proved so eager and adept when charge bargaining is not likely to have overlooked the potential of the onfile mechanism for ending cases quickly and well.

Three years later, when the legislature set out to squelch charge bargaining in liquor cases by banning prosecutorial nol prosses, Train had an alternative at the ready. The on-file mechanism proved to be peculiarly adapted to his dilemma. Because placing a case on file postponed it indefinitely, the prosecutor never needed to exercise his now-banned nol pros power. And because cases placed on file were not technically "disposed," the clerk did not fully record them in the official record books. The difficulty of discerning what happened to these cases that our citizen of 1859 encountered a few pages back was quite convenient to Train, his successors in Middlesex, and his counterparts across the state, for it helped prosecutors evade the legislature's evident wish to end deals in liquor cases.

All this would be but a curious historical footnote if the on-file manner of resolving cases had grown up and died in the nineteenth century. But this story of what Ferdinand calls "informal probation" 315 proves to be of real moment. For putting cases on file was probation. It was not merely an ideological forebear of the system of probation that first found expression in a Massachusetts statute of $1878 .{ }^{316}$ It was, as a matter of court procedure, the selfsame thing. Penologically, probation grew more advanced over time as probation officers came into being, but procedurally, it remained unchanged until almost the end of the century. For our purposes, the significance of this identity of probation and the on-file mechanism turns on these additional facts: Prosecutors had in most cases a unilateral (if not

313. In two cases, the clerk did not name the charge.

314. Ferdinand's figures from Boston also show a greatly expanding use of the on-file mechanism in the $1840 \mathrm{~s}$. Unfortunately, he does not distinguish between cases that also involved a guilty finding and those in which the defendant defaulted, a witness left town, or the case for some other reason was abandoned. See FERDINAND, supra note 121. at 60.

315. Id. at 69.

316. See Act of Apr. 26, 1878, ch. 198, 1878 Mass. Acts 146, $1+6$. 
exclusive) power to place cases on file. And as we have seen prosecutors do in other contexts, they converted their power to the purposes of plea bargaining. By using probation as an instrument of plea bargaining, prosecutors gave this most famous of nineteenth-century contributions to criminal procedure much of its initial vigor.

This argument that probation grew up in symbiosis with prosecutorial plea bargaining breaks into two claims, which are the topics of the next two Sections: First, the on-file mechanism provided prosecutors with all the power they needed to invent a new form of plea bargaining, a power they promptly exploited. And second, this practice of putting cases on file is the same one that Massachusetts later exported to the nation and the world under the label "probation." Proving the former claim will tax us with close readings of statutes and cases to define the prosecutor's power to put cases on file. Here the very tedium of the work is part of our story. I argued earlier that nineteenth-century prosecutors had a built-in interest in plea bargaining, but they achieved the power to satisfy that interest only rarely, either by extraordinary legislative grant or by procedural ingenuity. In Part I, I explored the consequences of the extraordinary grant of power that the legislature unwittingly made by attaching rigid penalty schemes to liquor laws and capital offenses and by leaving unchecked the prosecutorial power to nol pros. In the investigation we now begin, I will try to expose the ingenuity of Massachusetts prosecutors in turning a small procedural device-the simple formality of moving (or not moving) for sentence-into the on-file form of plea bargaining.

As intricate as this examination of prosecutorial powers will be, I do not mean to suggest that the particular array of powers that prosecutors discovered in the on-file mechanism was essential to prosecutorial plea bargaining. ${ }^{317}$ Rather, I believe that most nineteenth-century prosecutors would have devised a means to plea bargain given any constellation of powers. In this sense, Massachusetts is just a case study. Later I will examine how prosecutors in other places used the particular powers available to them. For now, we must explore how Massachusetts prosecutors crafted a covert plea-bargaining regime from the various vagaries of Massachusetts practice. In the process, we may see how prosecutors raised up probation as a sibling of plea bargaining and shaped it to do plea bargaining's bidding.

317. In 1916, in the course of ruling that federal trial courts had no power to suspend the imposition of sentence in the absence of federal probation legislation, the United States Supreme Court canvassed state practice and found Massachusetts to be in the minority of states that recognized a non-statutory practice of staying sentences indefinitely. See Ex parte United States, 242 U.S. 27,47 \& n. 1,48 \& n.1, 50-52 (1916). 


\section{A. The Prosecutor's Powers and On-File Plea Bargaining}

Jerusha Chase's business before the Boston Municipal Court on February 8,1830 , began with a guilty plea: "Defendant retracts her plea [of not guilty] and pleads guilty ...." 318 Her business ended with a generous result: Instead of imposing sentence, the court released her into the custody of her companions on a promise, backed by a pledge of cash, of her future good behavior. Her case was then placed on file. But can we call this an onfile plea bargain? Who, if anyone, promised Chase that if she pled guilty, her case would be placed on file--or from whom did she expect this result? These questions raise another: Who had the power to grant Chase this result?

The evidence is strong that Chase was in fact a plea bargain and that Jerusha Chase's bargaining partner was not the judge, but rather her prosecutor-James Austin, the Suffolk County Attomey. ${ }^{319}$ We have met Austin before. In 1841, having risen to the post of attorney general, he engineered the first capital charge bargains that I encountered in Massachusetts. ${ }^{320}$ What we learned about prosecutorial charge bargaining when studying the work of Austin and others in Part I gives us some idea of the powers he would have wanted and needed to craft an on-file plea bargain. In liquor and murder prosecutions, prosecutors needed two sorts of power to mount a vigorous charge-bargaining practice: the power to protect defendants against unpleasant surprise at the judge's hands during sentencing and a corresponding power to protect themselves from the judge's undue leniency. The question now is whether prosecutors found these powers in the on-file mechanism.

\section{The Power To Protect Defendants from Judicial Severity}

In liquor cases, the prosecutor's power to promise the defendant a specific sentence in exchange for the defendant's guilty plea derived from the liquor law's fixed penalty scheme and the prosecutor's unreviewable power to nol pros additional counts of the indictment. In murder cases, the prosecutor's power to reduce the charge to manslaughter and thereby lift the threat of death accomplished the same purpose. Although the prosecutor could not promise the defendant a specific sentence within the zero-to-

318. Grinnell, supra note 300 , at 604 .

319. See Commonwealth v. Jerusha Chase (Boston Mun. Cl. 1831), in REPorTs of CRIMINAL CASES, supra note 301, at 268; 1 DAVIS, supra note 14, at 223; supra notes $92-94$ and accompanying text. It is clear from these sources that Austin served at the relevant times as county attorney and that he handled at least the later proceedings in Chase. It is possible that he did not personally conduct every stage of the prosecution.

320. See supra notes $92-94$ and accompanying text. 
twenty-year range provided for manslaughter, the prosecutor could promise "not death" and "at most twenty years"- surely enough to convince many defendants to plead guilty. If the on-file mechanism proved a source of prosecutorial plea bargaining, then it must in a similar way have given prosecutors the power to limit the sentence the judge could impose.

In search of this prosecutorial power to limit sentence, I set out to discover which courtroom actor-prosecutor or judge-had the power to put cases on file. Like so many other questions I asked in the course of this study and in others, this question proved to be the wrong one. It turns out that the power to place cases on file is only a cover for the power that matters: the power to stay sentence. But though misguided, my question did not prove fruitless. I went in search of the power to place cases "on file" because that was the discourse of the day. And just as I was deceived about where the relevant power lay, so it appears some contemporaries were too. For while the power to place cases on file migrated into judges' hands, where some no doubt thought it should be, the power that really mattered remained in most cases and for a long time firmly in the prosecutor's grip.

The record and docket books of the Middlesex courts give an intriguingly garbled response to my initial inquiry about the power to put cases on file. I quoted earlier from the record book for 1859 , which says flatly that "the Attorney for the Commonwealth ... orders [these cases] on file." ${ }^{321}$ A few years earlier, in 1853, the clerk was even more pointed: "The following Indictments and Complaints, Charles $\mathrm{R}$ Train Esquire, Attorney for the Commonwealth in this behalf, orders to be placed on file." 322 But going forward from 1859, we find more mixed meanings. Between 1860 and 1876 , the clerk often attributed the on-file list to the district attorney (seventeen times) and less often to the court (eight times). But with interesting frequency, the clerk simply neglected to say who had ordered that the standard list of cases be placed on file: Seventeen times in these years, the clerk wrote, "The following Indictments and Complaints, to wit," and then listed dozens of names-but never finished his sentence. ${ }^{323}$ Docket books for these years make it clear that the listed cases were placed "on file," but do not say by whom. ${ }^{324}$ Then, from 1877 on, the clerk wrote clearly and consistently that the listed cases were, "by order of the Court, placed on file." 325 This variance across the decades is not the only confusion we encounter. In 1859 , for example, some of those cases that

321. Middlesex Ct. C.P. R. Book (Feb. 1859).

322. Middlesex Ct. C.P. R. Book 55 (June 1853).

323. See, e.g., Middlesex Super. Ct. R. Book $145-46$ (June 1870); Middlesex Super. Ct. R. Book 1 (Feb. 1870); Middlesex Super. Ct. R. Book 133 (Oct. 1864); Middlesex Super. Ct. R. Book 2 (Feb. 1864).

324. See, e.g., Commonwealth v. Jeremiah Dempsey, Middlesex Super. Ct. Docket Book No. 52 (Oct. 1864).

325. See, e.g., Middlesex Super. Ct. R. Book 1-2 (Feb. 1877). 
appear in the record book as having been ordered on file by the district attorney appear in the docket book as having been ordered on file by the court. ${ }^{326}$

Perhaps Ferdinand saw the same sort of confusion in Boston, for he concludes simply that the decision to put a case on file "may be initiated by the judge as well as the prosecutor" and that "[u]nfortunately, it was not possible to differentiate the prosecutor's [decisions] from those of the judge." ${ }^{327}$ I think the best conclusion to draw from this jumble is that the power to place cases on file shifted haltingly over the third quarter of the century from the prosecutor to the judge. It is surely possible too that the clerk himself did not always know who had placed cases on file, or even that the clerk did know but felt (because it was impolitic to attribute too much power to the prosecutor?) that it was better not to say.

Statutes are not much more useful than court records in this search. With some unintended humor, the Supreme Judicial Court wrote in 1874 in Commonwealth $v$. Dowdican's Bail that "this practice [of putting cases on file] has been recognized by statute. Sts. 1865, c. 223 ; 1869, c. 415 , $\S 60$." 328 One catches the irony only after looking up the statutes. It turns out we have seen both of these already: The 1865 citation traces to the "Act To Prevent Evasions" of the liquor law, which provided that "[n]o [liquor] case ... shall be laid on file," except with the court's consent, and the 1869 citation leads to the legislature's reenactment of the same ban. ${ }^{329}$ From the court's reference and these two statutes, we learn two important facts, each suggested by negative inference. First, by listing as the only statutory authority for the practice two laws that greatly restricted the power to put cases on file, the Supreme Judicial Court implied that formerly there was a practice without statutory authority. Second, by making a point of writing and then reenacting a law that barred placing liquor cases on file without the court's consent, the legislature implied that prosecutors formerly put liquor cases on file without the court's consent.

The legislature perhaps came to the conclusion that prosecutors were unilaterally placing cases on file as a result of the 1865 hearings on

326. See, e.g., Commonwealth v. Patrick Brady. Middlesex Ct. C.P. Docket Book No. 957 (Feb. 1859) (noting that the case was "ordered on file by Court"). In fact, even within the 1859 Record Book, there is confusion. Although the district attorney is credited with having placed the long list of cases on file, there are five other cases (none of them liquor cases) to be found elsewhere in the recond book, all of which the court placed on filc. See, e.g., Commonwealth v. Edward Dyer \& Thomas E. Berry, Middlesex C. C.P. R. Book 181 (June 1859) ("The Courn order that the defendants go on probation, and that the indictment be placed on file against them.").

327. FERDINAND, supra note 121, at 71-72. Ferdinand writes nonetheless that the growing practice of putting cases on file "represented a clear expansion of [the prosccutor's] powers." $/ d$. at 69. Elsewhere, he analyzes the municipal court's various judges party in terms of their willingness to place cases on file. See id. at 128-33.

328. Commonwealth v. Dowdican's Bail, 115 Mass. 133, 136 (1874).

329. See supra notes 281-283 and accompanying text. 
enforcement of the liquor laws that led later the same year to the Act To Prevent Evasions. ${ }^{330}$ Among the witnesses at the hearings was George P. Sanger, district attorney of Boston's Suffolk County, who said that until his office recently discontinued the practice, "it was thought, if we collected the costs, and placed the case on file, it was better, after a verdict of guilty," than to press for sentence. ${ }^{331}$ Whether based on Sanger's admission that "we" placed cases on file or on some other evidence, several members of the committee that heard his testimony wrote in their report that "witnesses said that attorneys evaded the prohibitory law by ... placing cases on file" - and then added that such "attorneys act upon the same principle as the liquor dealers, whom they try to shield, and prostitute their honorable profession to a connivance with vice, regardless of justice and humanity." 332

By directing such harsh language at lawyers and by enacting soon afterward a law to prevent prosecutors from putting liquor cases on file without the court's consent, legislators seemed to declare their belief that prosecutors were placing cases on file. It is unclear whether the Act To Prevent Evasions succeeded in preventing prosecutors from placing liquor cases on file. On the one hand, Middlesex Superior Court record books show a marked disruption of on-file plea bargaining in liquor cases. In the two terms of court I studied in 1864 the last year before the law changeI observed eleven on-file plea bargains in liquor cases. I saw only one in the single term of court I studied in $1870 .{ }^{333}$ And in 1900 , the last year I studied in depth, only twelve of 225 on-file plea bargains took place in liquor cases ${ }^{334}$ On the other hand, some evidence suggests that judges in Suffolk County readily gave their consent to prosecutors' requests to place liquor cases on file. ${ }^{335}$ We need not resolve this uncertainty, for even while the

330. I infer that the hearings led to the Act To Prevent Evasions from the coincidence of two legislative documents: The minority report of the committee that conducted the hearings, which complained of the practice of putting liquor cases on file, was issued on the same day that the bill to prevent evasions was reported by a separate committee. Compare S. DoC. No. 201, at 1, 6 (Mass. 1865) (minority committee report), with S. DoC. No. 205, at 1, 1-3 (Mass. 1865) (reporting the bill).

331. S. DoC. No. 200, at 22 (Mass. 1865) (statement of George P. Sanger). Sanger was speaking of prosecutions under the liquor-nuisance act, not the prohibition act, but because the Act To Prevent Evasions applied to both acts, the distinction is unimportant here.

332. S. DOC. No. 201 , at 6 (minority committee report). The minority opposed the recommendation of the committee that the state revert from a prohibition law to a license law. See S. DOC. No. 200 , at $44-45$.

333. See Commonwealth v. Joseph Alexander, Middlesex Super. Ct. Docket Book No. 874 (Feb. 1870).

334. I am counting both license law and liquor-nuisance cases, as the 1865 Act and its successors treated them symmetrically.

335. The clerk's papers for Commonwealth v. Dowdican's Bail, 115 Mass. 133 (1874), contain the judge's "certificate" that the act requires before a liquor case may be placed on file. The preprinted form reads, "In this case, No. [blank] of 18 [blank], against [blank] I certify that I am satisfied the cause relied on in the annexed affidavit exists, and that the interests of public justice require the allowance of the motion to lay the case on file." Judge's certificate (June 5. 
nominal power to place cases on file appeared to be shifting toward the judge, the real power lay elsewhere.

The language of placing cases "on file" appears so prominently in the court's docket books that I was blinded at first to the right question, though it should have been clear all along. For this study of plea bargaining's rise is not much concerned with those cases that ended up on file because a defendant or witness left town. Rather, we want to know about those cases in which the defendant pled guilty and then, just when the judge normally would have passed sentence, someone instead put the case on file. In these cases, the important question is not who placed the case on file-that is merely the mechanism that held the case in abeyance while sentence was stayed-but rather who stayed the sentence. And the surprising answer to this question is that the prosecutor did.

To track the prosecutor's power to stay sentence, we have to go back to 1830 and the case of Jerusha Chase. The trial judge, Peter Oxenbridge Thacher, wrote that after Chase pled guilty, "sentence would have been pronounced..., but upon the application of her friends, and with the consent of the attorney of the commonwealth, [the defendant] was permitted, upon her recognizance for her appearance in this court whenever she should be called for, to go at large." ${ }^{336}$ Thacher has been quite vague here about the distribution of the power to stay Chase's sentence: Her "friends" applied for the stay; the prosecutor "consent[ed]" to it; and it "was permitted"-presumably by the court. ${ }^{337}$

Compare, now, the reporter's headnote to the case, which appears on the page before the judge's summary and most likely was written in the early 1840s: The "defendant pleaded guilty to an indictment, and the prosecuting officer did not move for sentence, but laid the indictment on file, and the defendant was permitted to go at large." 338 The reporter helpfully has alerted us that the procedure Thacher described was actually the "on file" mechanism-something Thacher confirmed in noting that the "indictment has been suffered to sleep upon the files of the court." 339 And the reporter has clearly named the prosecutor as the actor who filed the case. More importantly, the reporter suggested that "mov[ing] for sentence" and "la[ying] the indictment on file" were mutually exclusive-

1867), Dowdican's Bail (No. 2024) (on file with the Supreme Judicial Cour Archives, Boston). The underlying affidavit to which the form refers appears to have been lost, but it is described in the case notes to the Supreme Judicial Cour's opinion as having claimed that the indicuments in question were duplicative of another. See Dowdican's Bail. 115 Mass. at 134.

336. Commonwealth v. Jerusha Chase (Boston Mun. C. 1831), in REPORTS OF CRIMINAL CASES, supra note 301, at 268.

337. Id.

338. Id. at 267.

339. Id. at 269 . 
that is, placing a case on file is what a prosecutor did instead of moving for sentence. ${ }^{340}$

The question now is whether the prosecutor's failure to move for sentence actually barred the judge from passing sentence. If not, then the prosecutor's promise to withhold his motion would have enticed very few defendants to plead guilty. We have seen already some hints that the prosecutor could in fact block judicial sentencing. Recall that in 1847, District Attorney Albert Nelson announced "that at the present term, it is his intention when the parties complained of plead guilty [in liquor-license cases], and enter into recognizance to observe the law, not to press for the fines which are incurred, but simply to exact the costs of Court." ${ }^{341}$ As fines were mandatory under the liquor-license law, Nelson's failure to "press for the fines" must have relieved the judge of the obligation to pass sentence, ${ }^{342}$ though we cannot yet be sure that it barred the judge from sentencing. Similarly, when the legislative committee I mentioned met in 1865 to consider enforcement of the liquor laws, it asked whether the district attorneys had failed "to bring the convicts to sentence, or to enforce the sentence." 343 The prohibition law at the time called for mandatory confinement, so again the district attorney's failure to move for sentence must have released the judge from the law's directives. But did it prevent the judge from passing sentence?

One hint that it did is a remark made almost in passing by the Supreme Judicial Court in 1838: "After a verdict of guilty is rendered, the defendant is to be sentenced on motion of the attorney general; and we have no doubt of his authority to enter a nolle prosequi after verdict." ${ }^{344}$ The court implied that the prosecutor had full discretion to choose between passing sentence and forgoing it and that the prosecutor's motion for sentence was a prerequisite to passing sentence. But we have to travel several decades forward to find more conclusive evidence on the point. In 1899, a southern Massachusetts district attorney, Robert Harris, submitted his report to the Plymouth County Commissioners. In remarking on the awesome responsibility of sentencing, Harris wrote, "The District Attorney has a large judicial discretion. He can decline to ask for sentence, or he can ask

340. Id.

341. License Cases, supra note 79.

342. I think it is fair to assume that Nelson's promise not to "press for the fines" amounted to a promise not to move for sentence. The only other possibility is that Nelson intended to nol pros each case on payment of costs after a guilty plea. But because part of the deal he proposed was that the defendant would "enter into recognizance to observe the law" in the future, id.. and because I have not seen this condition attached to a nol pros, whereas it was, as we will sec, often part of an on-file plea arrangement, I think it more likely that Nelson was promising that the case would be put on file, see infra notes 382-386 and accompanying text.

343. S. DOC. No. 200, at 5 (Mass. 1865).

344. Commonwealth v. Tuck, 37 Mass. (20 Pick.) 356, 366 (1838). 
for it, and until he asks that sentence be imposed, the court can do nothing." 345

A shrewd reader might appraise Harris's claim of power warily, as it surely served his interests. But in two rulings during the next few decades, the Supreme Judicial Court affirmed that the prosecutor had all the power Harris claimed. In the later of the two, Commonwealth v. Kossowan $n^{3+6}$ of 1929, the court mildly chastised a trial judge for not passing sentence despite an 1895 law declaring that "[o]n conviction of any offense not punishable by death, sentence shall be imposed." 347 "The reasons why sentence was not promptly imposed do not appear," the court wrote. ${ }^{3+18}$ "Manifestly the case was not filed or prosecution suspended. The case of Commonwealth v. Carver is not pertinent." ${ }^{3+9}$ If we turm now to Carver, we may expect to find an exception to the statutory command that the trial judge pass sentence upon conviction. In that 1916 case, a jury had convicted the defendant on two indictments, one alleging forgery and one larceny. The trial judge did not pass sentence on the forgery indictment. "The reason for this," the high court wrote, "presumably is that ... this case was placed on file." ${ }^{350}$ Declining to review the defendant's claims of error in the forgery case, the court concluded that

the exceptions taken in that case are not properly before us. There has been merely a suspension of active proceedings in the case, and as yet no final disposition. Unless and until the prosecuting attorney shall move for sentence there is no occasion to pass upon the conduct of the forgery trial. ${ }^{351}$

It is impossible, I think, to escape the combined force of Harris's claim and the court's statements in Kossowan and Carver. Even after an 1895 law required judges to pass sentence upon conviction, Harris still could claim that "until [the district attorney] asks that sentence be imposed, the court can do nothing," 352 and the high court could declare that "[u]nless and until the prosecuting attorney shall move for sentence there is no occasion" for a case to be finally disposed. ${ }^{353}$ Moreover, a 1926 commentator on

345. ROBERT O. HARRIS, REPORT OF DISTRICT ATTORNEY (1898), reprinted in REPORT OF THE COUNTY COMMISSIONERS OF THE COUNTY OF PLYMOUTH 116 (Plymouth. Avery Printing 1899). Two pages later, Harris wrote, "We [the district attomeys] can 'continue for sentence," 'place on file,' or allow the men to go on their own recognizance." Id. at 118.

346. 265 Mass. 436 (1929).

347. Act of June 4, 1895, ch. 469. §1, 1895 Mass. Acts 532. 532 (discussing the sentences for certain crimes).

348. Kossowan, 265 Mass. at 438.

349. Id. (citation omitted).

350. Commonwealth v. Carver, 224 Mass. 42,44 (1916).

351. Id.

352. HARRIS, supra note 345 , at 116.

353. Carver, 224 Mass. at 44. 
Massachusetts law complained that "[a]nother loophole that should be closed up is one which permits the District Attorney to delay presenting a person to the court for sentence who has been convicted." 354 It is true that this evidence emerges late in our story. Absent contrary evidence, however, the most reasonable conclusion is that the prosecutor's power to bar sentence by failing to move for sentence was more secure before the 1895 law than after. This power would explain Nelson's confident 1847 promise of a fine-free disposition for liquor defendants who pled guilty, ${ }^{335}$ as well as the legislative committee's 1865 complaint that district attorneys had failed "to enforce the sentence" demanded by the liquor law. ${ }^{356}$ Note how unimportant the question I posed at the outset of this search now seems: A defendant who wanted to negotiate a plea bargain with the prosecutor would not have cared whether the prosecutor or the judge had the power to place her case on file, so long as the prosecutor had the power to assure that the defendant would not be sentenced.

Drawing this confusion of sources together, we may take stock of the prosecutor's power to bar sentence once the defendant has been found guilty-and therefore of his power to ensure that the case would be placed on file. In liquor cases after 1865, the Act To Prevent Evasions disturbed this power in ways that are difficult to disentangle. In earlier liquor cases and in cases involving any other charge, the prosecutor's power was largely a function of his complete discretion to move or not to move for sentence. Because the court could not pass sentence until the prosecutor so moved, the prosecutor had a unilateral power to prevent the imposition of sentence, leaving no other option than to file the case. So our search for the first half of the bundle of powers needed for prosecutorial plea bargaining is complete: In prosecutorial charge bargaining, the prosecutor could guarantee liquor defendants a particular fine and murder defendants a sentence other than death. In on-file plea bargaining, the prosecutor could promise the defendant no sentence at all.

We may now return to Jerusha Chase. The court clerk, as I noted at the outset, recorded her guilty plea and noted as well that she recognized with sureties in the sum of $\$ 200$. If we add to this the news supplied by the headnote to Judge Thacher's opinion-that the prosecutor refrained from moving for sentence and the case therefore was placed on file ${ }^{357}$-we can reconstruct the course of events that probably lay behind these accounts.

354. Frank A. Goodwin, Community vs. Criminal, MASS. L.Q., May 1926, at 16. The author continued: "There are hundreds of cases where the machinery of the State, at great expense, has been used to convict a man and then for months and even years the record reads 'still pending for sentence." Id.

355. See supra note 341 and accompanying text.

356. See supra note 343 and accompanying text.

357. See Commonwealth v. Jerusha Chase (Boston Mun. Ct. 1831), in REPORTS OF CRIMINAL CASES, supra note 301, at 267. 
First, Jerusha Chase pled guilty in exchange for the prosecutor's promise that he would not move for sentence. Second, because the judge could not pass sentence without the prosecutor's motion, the case was placed on file. And third, Chase was permitted to go after she and her sureties pledged $\$ 200$ to guarantee that she would "come when sent for and in the meantime... keep the peace." 358

It is true that the records do not say in so many words that Chase struck a deal with the prosecutor. To get from the information that the defendant pled guilty and the prosecutor failed to move for sentence to the conclusion that she pled guilty in exchange for his promise, I must make an inferential leap, but a short one. It is possible that the defendant pled guilty out of remorse or for some other reason and not because the prosecutor promised leniency, and it is possible that the prosecutor refrained from moving for sentence as a simple matter of good (and generous) prosecutorial judgment after the defendant had pled guilty, but the combined probability of these two events is rather small.

Moreover, we have seen so far at least two pieces of circumstantial evidence that cases that look like Chase on the face of the record in fact involved an explicit deal between prosecutor and defendant. The more powerful is District Attorney Nelson's 1847 announcement that "at the present term," he would "not ... press for the fines" for those defendants who pled guilty in liquor-license cases. ${ }^{359}$ It is hard to escape the implication of Nelson's announcement that behind the clerk's reticent notes of cases placed on file after the defendant's plea, there lay an explicit agreement between prosecutor and defendant. The second piece of circumstantial evidence is the surge in use of the on-file technique that took place in Middlesex under District Attorney Train's watch in $1849 .{ }^{360}$ It is hard to imagine that so prolific a plea-bargaining pioneer as Train, who not only raised charge bargaining in liquor cases to a new order of magnitude but also negotiated Middlesex County's first charge bargain in a murder case, should have overlooked the potential for plea bargaining in the on-file mechanism.

\section{The Prosecutor's Power To Protect Himself from Judicial Leniency}

We must search now for the second sort of power essential to successful prosecutorial plea bargaining-the prosecutor's power to protect himself from the judge's whim. Again, the forms of charge bargaining we studied in Part I make the importance of this power clear. The prosecutor's

358. Grinnell, supra note 300 , at 604 (quoting the original record).

359. License Cases, supra note 79; see also supro note 79 and accompanying text (quoting the press account of Nelson's announcement in full).

360. See supra notes 313-315 and accompanying text. 
worry in charge bargaining was that after he had nol prossed several counts of an indictment, the judge would hand the defendant too lenient a sentence on the remaining counts. The liquor law's rigid penalty scheme guarded against this result by requiring the judge to impose a particular fine. The prosecutor's inability to guard against an inappropriately light sentence on a manslaughter conviction in fact may have limited charge bargaining in murder cases and might explain why pleas to second-degree murder, which carried mandatory life in prison, proved in the end the more popular option.

In on-file plea bargaining, the prosecutor faced no immediate risk of unfair dealing at the judge's hands because the judge had no immediate role. By failing to move for sentence, the prosecutor left the judge nothing to do except (perhaps) to perform the ministerial task of placing the case on file. The judge's chance to undermine the prosecutor's position in on-file plea bargains came later, and this brings us to the second half of the bargain the prosecutor reached with Jerusha Chase-her agreement "to keep the peace." 361

Chase returned to court in 1831 under indictment for a new larceny. Although a jury acquitted her of the second crime, prosecutor Austin apparently believed strongly enough in her guilt to conclude that she had violated her pledge to keep the peace and therefore moved that she be sentenced on the original indictment. ${ }^{362}$ Now we reach the point at which the judge could have frustrated the prosecutor's well-laid plans either by refusing to pass sentence or by passing a light one. After all, the prosecutor until now had shown the defendant great leniency in allowing her to walk free without ever facing sentence. On-file plea bargains would have held small allure for a responsible prosecutor if he had been vulnerable to judicial refusal to act when, following the defendant's later breach of the peace, he decided to call in the case for sentence.

The question, then, is whether the prosecutor's unilateral power to stay sentence was also an exclusive power: If the district attorney moved for sentence, could the court nevertheless place the case on file? And if the district attorney moved to take a case from the file and have sentence pronounced, could the court refuse? Judge Thacher's opinion in Chase suggested that the answer to both questions was no. We already have seen some hint of this result in Thacher's statement that he had permitted the defendant to go at large "with the consent of the attorney of the commonwealth." ${ }^{363}$ When Thacher turned to the question squarely before

361. Grinnell, supra note 300 , at 604 (quoting the original record).

362. See Commonwealth v. Jerusha Chase (Boston Mun. Ct. 1831), in Reports Of CRIMINAL CASES, supra note 301, at 267. Chase's situation was similar to that of the modern probationer, whose probation can be revoked on a probable-cause showing of a further crime even if a jury has refused to convict by the standard of beyond a reasonable doubt.

363. Id. at 268 . 
him-whether prosecutor Austin had the power to return to court and demand that Chase be sentenced on her original conviction-he first equivocated, but then by stages grew clear and direct. His first approach to the problem left considerable ambiguity about whether the court could refuse a prosecutor's request for sentencing: "I cannot doubt the court may, on motion, have the party brought in and sentenced at any subsequent period." ${ }^{364}$ But his next sentence appears to erase the court's discretion in the matter: "For what was the duty of the court to do at any one time, cannot cease to be its duty by delay." ${ }^{365}$ And a page later, Thacher implied in striking language that the prosecutor's discretion was complete: "[Chase's sentence] has been delayed from tenderness and humanity, and not because it had ceased to be the right of the government to claim the judgment." 366

The Supreme Judicial Court approved Thacher's reasoning in an unreported opinion, ${ }^{367}$ but apparently did not again take up the matter of filed cases until Dowdican's Bail in 1874. That case, like Chase, examined the prosecutor's power to remove a case from the files after the defendant was charged with a later offense. As in Chase, the court began by remarking on the power to file the case in the first instance. "It has long been a common practice in this Commonwealth," the court wrote, "after verdict of guilty in a criminal case," for the trial court to "order" the case on file "with the consent of the defendant and of the attorney for the Commonwealth." 368 Having now seen this reference to the prosecutor's "consent" twice in the same context, we may fairly conclude that this consent was a precondition to placing a case on file, at least after a guilty verdict gave the prosecutor the right to move for sentence.

The Dowdican's Bail court did not, however, adopt Judge Thacher's pointed declaration in Chase that the prosecutor had the power to have a case taken from the files and to have sentence pronounced. Instead, the court noted only that it was "within the power of the cour at any time, upon the motion of either party, to bring the case forward and pass ... judgment therein." ${ }^{369}$ From this we may conclude that the court had no power to remove a case from the files without a motion from the prosecutor (or from the defendant, though it is hard to imagine why a defendant would move for sentence). We may also conclude that the

364. Id

365. Id.

366. Id. at 269.

367. In a concluding footnote to Thacher's opinion, the reporter noted that the Supreme Judicial Court had pronounced the judgment correct in an opinion by Chief Justice Lemuel Shaw and "that the principles of the above decision have often been recognized in our courts." ld. at $270 \mathrm{n} .1$. The high court's opinion is apparently missing. See Grinnell, supra note 300 , at 603.

368. Commonwealth v. Dowdican's Bail, 115 Mass. 133, 136 (1874).

369. Id. 
prosecutor could bring such a motion no matter how long the case had sat on file. ${ }^{370}$ But we cannot be sure that if the prosecutor brought a motion, the court had to grant it.

I have found just one other reference that might help trace the boundary of the prosecutor's power to prevent a judge from placing (or from leaving) a case on file. In 1917, F.W. Grinnell wrote that "doubt... has been expressed in Massachusetts" about whether a judge could place a case on file if the district attorney moved for sentence. ${ }^{371} \mathrm{He}$ then argued that "the doubt has been resolved" and that "it is the established practice of the state ... that the District Attorney is not entitled to insist upon sentence." 372 Grinnell apparently based this conclusion on Commonwealth v. Macey, an unreported decision of a Massachusetts Superior Court trial judge, in which the judge ruled in favor of his own power to continue a rape case without sentence even after the jury had convicted the defendant and the district attorney had moved for sentence ${ }^{373}$ But Macey was decided sometime after $1898,{ }^{374}$ and a statute of that year may have given judges grounds to construe their powers in this area more generously. ${ }^{375}$ Even if Macey is representative of the state of affairs after 1898-and we cannot be sure that it is-we still should give it fairly small weight in assessing who held the power to stay sentence during the bulk of the nineteenth century.

Once again drawing our confusion of sources together, we may measure the reach of the prosecutor's power to demand that a case be taken from the files and sentence imposed. There seems to be no dispute that timing was not an issue-that is, the prosecutor could move for sentence at any time in the future. If he did, the court was then required to impose sentence (Chase, 1831); or might have been required to impose sentence (Dowdican's Bail, 1874); or was not required to impose sentence (Macey, after 1898). And if the prosecutor in the first instance moved for sentence upon conviction, the court had no power to place the case on file instead (Chase, 1831, and Dowdican's Bail, 1874)—or indeed had this power (Macey, after 1898).

These conclusions suggest that the answer to our underlying inquirywhether the on-file mechanism gave prosecutors the power to protect

370. The time lapse in Dowdican's Bail itself, which the court impliedly approved by upholding judgment against the defendant's sureties, was six years. See id. at 133-34.

371. Grinnell, supra note 300 , at 593 . In this sentence and the next, Grinnell was quoting from a brief he co-wrote with R.W. Hale. Grinnell implies that the brief was largely his work, and as that seems likely, given the context, I am attributing these quotes to him. See id. at 592 ("It was in the course of the preparation of that brief that parts of this article were compiled ....").

372. Id. at 593 .

373. See id. at $593 \&$ n.*.

374. Grinnell supplied no date for Macey, but he did say that the judge's name was Bell, see id. at $593 \mathrm{n} . *$, and the only Bell to sit on the superior court bench (as of 1900) was appointed in 1898, see DAVIS, supra note 7 , at 254-55, 267, 417.

375. See infra notes $408,413-416$ and accompanying text. 
themselves against undue judicial leniency-changed as the century wore on. Early in the century, Judge Thacher's holdings that imposing sentence "cannot cease to be [the court's] duty by delay" and that sentence was "delayed from tenderness and humanity, and not because it had ceased to be the right of the government to claim the judgment" 376 protected prosecutors from judicial refusal to act. Later in the century, prosecutors had reason to feel more vulnerable to the risk of unjustified judicial generosity.

But even in the early years, the prosecutor's right to demand judgment generally did not include the right to demand a particular judgment. Except in liquor cases and those few others in which the law called for a mandatory penalty, the judge, called on to pass sentence, could impose a lenient one. This risk of judicial leniency probably discouraged prosecutors from using on-file plea bargaining in more serious cases. Of course, even if prosecutors had been assured of judicial severity when they brought the defendant in for sentencing, they still would have been slow to engage in on-file plea bargaining in serious cases. That is because in the first instance, on-file plea bargaining let the defendant walk free. Prosecutors who took to heart their duty to protect the public-or, after 1856, those concerned about their reelection-would not have engaged in on-file plea bargaining with the more serious criminals before the court.

Yet on-file plea bargaining was not as feeble a tool against criminals as the modern practice usually known as "pretrial probation." A defendant who accepts pretrial probation today places herself under the court's supervision before trial without pleading guilty or no contest. Typically, the court, the defendant, and the prosecutor agree that if the defendant abides by the law and adheres to any other condition imposed by the court for a specified period, the court will dismiss the charges-and in the meantime the case is simply held in abeyance. In on-file plea bargaining, as I use the term, the defendant always entered a plea of guilty or no contest before the case was placed on file. The distinction is important: If a defendant placed on pretrial probation commits a later offense, the prosecutor still must convict her of the original charge before the court can impose punishment on that charge. In on-file plea bargaining, as we saw in Chase, if the defendant committed a later offense or breached her deal with the prosecutor in any other way, the prosecutor could move for sentence without further ceremony. ${ }^{377}$ On-file plea bargaining therefore gave the

376. Commonwealth v. Jerusha Chase (Boston Mun. Ct. 1831), in Reports of Crminal. CASES, supra note 301 , at $268-69$.

377. See infra note 384 (quoting contemporary sources emphasizing that the defendant was always convicted before her case was placed on file and that imprisonment was an "invariabl[c]" consequence of reoffending). 
prosecutor a far stronger hand in controlling the defendant's future behavior.

It is true that as the century wore on, the power of prosecutors to claim judgment on the defendant's conviction grew less certain. Judges apparently felt freer to reject prosecutors' demands that a case be taken from the files and sentence imposed. This trend might have discouraged onfile plea bargaining had it not been for another judicial change in attitude: During the last quarter of the century, judges grew more friendly toward plea bargaining and less likely to act in ways that would discourage it. We will look in Part V at the reasons for the judges' change of heart. We can look now at one result.

From the beginning, defendants who went to trial and lost almost never won the reward of a filed case. In 1849, the first year I studied closely after the appearance of the on-file mechanism in Middlesex County, thirty-seven defendants who had pled guilty or no contest walked out of court with their cases filed. Only two defendants who lost at trial had such luck. In succeeding decades, the story was the same. In the years I studied between 1853 and $1890,{ }^{378} 166$ cases were placed on file after pleas of guilty or no contest-but only thirteen after convictions at trial. During most of these years, prosecutors apparently held the balance of power in awarding the onfile mechanism-and they apparently used this power to encourage pleas by withholding case-filing from defendants who troubled them with trials. By the end of the century, as we have seen, judges may have assumed more power to file cases. If so, then it seems they were just as ready as prosecutors to use the on-file mechanism to encourage defendants to plead guilty. In 1900, when 225 cases were placed on file after defendants had offered pleas of guilty or no contest (accounting for forty-one percent of all adjudicated cases), only six cases were placed on file after defendants chose trial and lost.

Here we seem to have another piece of circumstantial evidence that those cases in which the defendant pled guilty and the case was placed on file involved a clear deal in which the defendant pled guilty in exchange for having her case placed on file. Yet the numbers reported in the last paragraph confront us with two ambiguities. They cannot tell us whether the defendant was negotiating with the prosecutor or with the judge. And they cannot tell us whether any deals that took place were spoken or unspoken. After all, when a course of practice was this clear, it might simply have been understood by all parties, and defendants might have pled

378. I am including data only from those years for which I studied both the record and the docket books of the court: 1853, 1859, 1864 (February and October only), 1870 (February only). 1880 (October only), and 1890 (incomplete count of docket entries). 
guilty because they knew that doing so was their only real hope of having their case placed on file.

One piece of evidence seems to resolve both ambiguities. In 1886 John Maloney pled guilty to a liquor-related charge in the district court-the lower trial court-where no prosecutor represented the state. ${ }^{379}$ The trial court then continued the case indefinitely for sentence on payment of costs by the defendant. ${ }^{380}$ When the court later imposed sentence against the defendant-perhaps because he had violated the terms of his release-he appealed. In the course of its ruling, the Supreme Judicial Court compared the case to Dowdican's Bail, which had originated in the superior court:

The postponement [of Maloney's case, granted after the defendant's guilty plea,] was not, and was not intended to be, a continuance, but an end of the prosecution, unless the magistrate should see cause at some future time to notify the defendant that sentence was to be pronounced. It was obviously an arrangement between the trial justice and the defendant, like that sometimes made in the higher courts between the prosecuting officer and a defendant, with the approval of the court, by which, on payment of costs by the defendant, an indictment or complaint is "placed on file." 381

By "an arrangement," the court appears to have meant a plea bargain, though a genteel one. And in this passage, the Supreme Judicial Court made it clear that in the "higher courts" - that is, the superior courts, which then occupied the middle tier of the state's judiciary-" the prosecuting officer and a defendant" struck these bargains.

\section{B. Probation's Base-Born Status}

At least from the days of Jerusha Chase, prosecutors had embraced the on-file mechanism and converted it to a form of prosecutorial plea bargaining. Now it is time to ask whether "on-file plea bargaining" could as aptly be called "probation." In this inquiry, the significance of the dual powers we examined in the last Section becomes clear. Prosecutors' unilateral (and sometimes exclusive) power to stay sentence constituted their power to plea bargain-it is what enabled them to promise sentencing concessions without fear of interference from the judge. Prosecutors' exclusive (and sometimes unilateral) power to take cases from the file and

379. See Commonwealth v. Maloney, 145 Mass. 205. 210 (1887).

380. See id. (reporter's statement of the case).

381. Id. at 210 (emphasis added) (citing Commonwealth v. Dowdican's Bail. 115 Mass. 133 (1874)) 
demand imposition of sentence is what gave this particular practice the name probation.

A modern observer would have no difficulty seeing that Jerusha Chase, as she left court on February 8, 1830, was on something like probation. Having pled guilty to her crime, she nonetheless walked free, and "no sentence will ever be pronounced against [her]," Judge Thacher wrote, "if [she] shall behave [herself] well afterwards, and avoid any further violation of the law." ${ }^{382}$ Should she, on the other hand, break the law again, she may be "brought in and sentenced at any subsequent period." ${ }^{383}$ Some forty years later, Charles Russell Train defended the practice of putting cases on file by pointing to its probationary benefits. Arguing in his new role as Massachusetts attorney general, he advised the Supreme Judicial Court in Dowdican's Bail that " $[\mathrm{t}] \mathrm{he}$ defendant, in all cases where sentence was thus delayed ... : was put on his good behavior, and under bonds, as it were, to live honestly." 384

Our modern observer might find it somewhat puzzling that those "bonds" were secured not by a court probation officer, who today acts as "surety" without its financial connotations, but rather by private parties. Jerusha Chase, for example, "recognized in the sum of two hundred dollars with Benjamin Salmon, trader, and Daniel Chase, Cordwainer of Marblehead," 385 either of whom would have been liable to pay $\$ 200$ should Chase have failed to come to court when called for or to keep the peace. And any spark of recognition might fade away when our observer saw the prosecutor's heavy hand at work at what is now very much the court's business. At least in these early years, few or none were admitted to probation without the prosecutor's favor of withholding a motion for sentence. And all who were on probation, such as Chase and Dowdican, knew that their free time tolled when the prosecutor demanded his due. Yet this same practice emerged by the end of the century under the name probation and claimed fame as the state's singular contribution to American criminal procedure.

382. Commonwealth v. Jerusha Chase (Boston Mun. Ct. 1831), in REPORTS OF CRIMINAL CASES, supra note 301, at 268.

383. Id.

384. Brief for the Commonwealth at 2, Commonwealth v. Dowdican's Bail, 115 Mass. 133 (1874) (No. 2024) (on file with the Social Law Library, Boston). In the Senate's 1865 hearings on enforcement of the liquor law, witnesses referred to the probationary aspects of putting liquor cases on file. The assistant clerk of courts for Worcester testified, "It is always made a condition to promise to go out of the business, before placing a case on file, and there is always a conviction by plea of guilty, or by a verdict." S. DOC. NO. 200, at 28-29 (Mass. 1865) (statement of William A. Smith). The Suffolk County district attorney noted that "if the guilty person offended again, he could be and was invariably sentenced to imprisonment." Id. at 22 (statement of George P. Sanger).

385. Grinnell, supra note 300 , at 604 (quoting from the municipal-court record). 
To see that the on-file mechanism did not merely resemble probation or foretell it, but rather was probation by another name, we have to focus on the role of the sureties who guaranteed the defendant's good behavior while she was on probation and her future appearance should the court call for her. Jerusha Chase's sureties staked $\$ 200$ on their faith in her future conduct. ${ }^{386}$ But what of defendants who lacked friends of such means? Here we encounter the role of John Augustus, Boston bootmaker and penal reformer, named by himself and others the father of probation. ${ }^{387}$ Augustus was in the Boston Police Court one morning in 1841 when he hit upon the philanthropic formula that would occupy his life: ${ }^{388} \mathrm{He}$ would play the role of surety to indigent defendants whose cases were placed on file during a "season of probation." ${ }^{389}$

386. See supra notes $302-303$ and accompanying text.

387. See JOHN AUGUSTUS, A REPORT OF THE LABORS OF JOHN AUGUSTUS, FOR THE LAST TEN YEARS, IN AID OF THE UNFORTUNATE 4-5, 7 (Boston, Wright \& Hasty 1852); CharLes L. NewMan, SOURCEBOOK ON PROBation, PAROLE AND PARDONS 14 (1968) ("It was in America that the combination [of factors that constitute probation] was first set in motion, by the judges of the Boston Municipal Court in cooperation with John Augustus." ): 1 N.S. ThslasHEFF, ONE HUNDRED YeARS OF PROBATION, 1841-1941, at 7 (1941) ("In this country, the idea of probation as a distinct method of treating offenders is quite correctly ascribed to John Augustus ....").

388. See AUGUSTUS, supra note 387 , at $4-5$.

389. Id. at 34; see also id. at 37 (referring to his role as "surety"); TMMAsHefF, supra note 387 , at 17 (" $[T]$ he unofficial and benevolent persons who helped the judge in the application of probation, and who were to oversee the behavior of the probationer [were] commonly sureties...."). Augustus was typically obscure about the procedural posture of the cases he described in his chronicle. I have found only one explicit reference to placing cases "on file" in his work, and although the context is somewhat ambiguous. I think the most natural reading is that most of his cases were placed on file. Toward the end of his chronicle. Augustus described a case involving a seven-year-old boy charged with rape-a case unusual in itself but also more serious than most of those in which Augustus took par. See AUGUSTUS, supra note 387. at 95-96. Augustus wrote that the court granted his request to place the case on file before trial. He then added, "This is the only case where I became bail [i.e., surety] when the indictment was laid on file on a plea of not guilty, except perhaps, when parties have died." Id. at 95 . I read this sentence to mean that most of the rest of Augustus's cases were placed on file after a guilty plea or verdict. Elsewhere, Augustus refers to a cour that "continued [a group of his cases] from term to term for several months, as a season of probation." Id. at 34. A continuance "from term to $\mathrm{term}^{\text {" was }}$ often used by courts as a near synonym for the on-file mechanism. differing only in that it required a more regular reexamination into the case's status. See supro note $310-311$ and accompanying text.

One of the few clear descriptions of the procedural status of those Augustus helped comes from an account he reprinted from the Christian World of 1848:

Twelve boys, all of about nine or ten years of age, were brought into the Boston

Municipal Court one afternoon last week, to receive sentences for various criminal offences. They had been convicted, or had pleaded guilty, and their sentences had been standing postponed; some for nearly a year; others for less periods,-meanwhile they had been under bail. Most of them had been bailed by John Augustus.... [The judge] delayed sentence further....

AUGUSTUS, supra note 387 , at 58 . Note that the boys had already been convicted and awaited only sentencing. This postponement of sentence was the critical feature of the on-file mechanism.

Note also that this reporter omitted any mention of the prosecutor's role and left the impression that the judge could freely delay sentencing. Another news account reprinted by Augustus gave a fuller sense of the prosecutor's role, but remained at least ambiguous about whether the judge had the power to postpone sentence in the face of a prosecutor's motion for 
Augustus therefore added nothing new to the court's procedural repertoire, which was in place at least since the time of Chase, but merely filled an existing procedural role on behalf of the poor. His enduring contribution was to play that role with insight and to good effect. To decide whether particular defendants were "promising subjects for probation," 390 Augustus inquired into their reputations and the influences of their peers. While they were on probation, he made sure they were schooled or employed, and he gave "an impartial report to the court, whenever they should desire it." 391 That the district attorney's opposition to his work "gradually and rapidly" gave way is little surprise ${ }^{392}$ for Augustus's vision of the reformatory purpose of probation did not include contests about guilt: " $[\mathrm{N}]$ ine out of ten of [those for whom I stood surety] who were guilty have by my advice, pleaded guilty, and thus saved the Commonwealth the expense of a trial in each case." 393

Just as Augustus contributed no procedural innovation to the existing practice of probation, so the 1878 law that introduced the word "probation" into American criminal codes did little more than perpetuate his role. ${ }^{344}$ The act authorized Boston's mayor to appoint a probation officer who was to investigate defendants, advise the court if they "may reasonably be expected to be reformed without punishment," and then assist those placed on probation so as "to prevent their again offending." ${ }^{395}$ The act consumed barely more than a page of text and neither defined probation nor pretended to confer any power or to impose any procedure on any courtroom actor. As F.W. Grinnell wrote in 1917 , the act merely provided new officers to

sentence. The reporter quoted the district attorney as acceding to Augustus's request for a further continuance of sentence in a petty-larceny case: "We do not wish to punish, except for a purpose of waming others. I will not urge a sentence now ...." Id. at 20 (quoting an undated report from the Morning Post). The reporter concludes, "His Honor listened attentively to the remarks of the worthy philanthropist, and granted the request." $l d$. Of course, in a petty-larceny prosecution, in which the allowable sentence range was zero to one year or zero to $\$ 300$, see MASS. REV. STAT. ch. $126, \S 17$ (Dutton \& Wentworth 1836), the question whether the prosecutor could demand sentence at a particular time may have been academic, since the judge could pass a sentence of nothing at all. In any event, the power the prosecutor needed to do on-file plea bargaining. as I discussed earlier, see supra notes $322,336-358$ and accompanying text, was the power to block sentencing by withholding a motion for sentence. The power to demand sentencing was important but inessential and, as we have seen, was at least uncertain at the time of Dowdican's Bail in 1874. See supra notes $367-370$ and accompanying text.

390. AUGUSTUS, supra note 387 , at 34 .

391. Id. at 35 .

392. Id.

393. Id. at 103; see also id. at 37 ("Almost all the cases in which I stood as surety were settled without being brought to trial; and pleas of guilt being put in, a door was opened for the mercy of the court ....").

394. See Act of Apr. 26, 1878, ch. 198, 1878 Mass. Acts 146, 146 (providing for the appointment of a probation officer for Boston); Grinnell, supra note 300, at 612 (noting that the act "is reputed to be the first act by any legislative body using the word "probation". in the relevant sense).

395. § 1,1878 Mass. Acts at 147. 
assist in a "well-established and well-recognized and approved existing usage." 396

As late as 1903, in fact, the Supreme Judicial Court described "probation" in a way that explicitly merged the concept with the on-file mechanism: "The defendant pleaded guilty in the Superior Court," the court wrote, "and having entered into the usual recognizance with the probation officer, as surety, he was placed on probation and the complaint against him was filed." " evolved much since Chase, except that now a public probation officer played the role of surety once taken by "Benjamin Salmon, trader, and Daniel Chase, Cordwainer of Marblehead." ${ }^{398}$ And just as Jerusha Chase lost her freedom when the prosecutor moved for sentence on the original indictment, so did the defendant in the case just quoted:

Later in the sitting the district attorney moved for sentence, and at the hearing thereon the judge found that the defendant had not kept the conditions of an oral agreement made between him and the Commonwealth, and under which he had been placed on probation, and that sentence ought to be imposed. ${ }^{399}$

396. Grinnell, supra note 300 , at 614 ; see also I TIMASHEFF, supra note 387 , at 17 (“) It is obvious that this statute introduced nothing essentially new into the common-law practice."). I have relied a good deal on Grinnell's study. Most importantly, he pointed out the strong connection between the practices described in Chase and probation as it later developed. In two ways, though, I disagree with his analysis. First, I believe he gave somewhat too much imponance to a law adopted in the Massachusetts 1836 code giving lower tribunals authority to relcase a defendant charged with certain minor crimes "upon his entering into a recognizance,.... with sufficient sureties, for his good behavior for a term not less than six months, nor more than two years." MASS. REV. STAT. ch. 143, § 9 (Dutton \& Wentworth 1836); see also Grinnell, supra note 300 , at $609-10$ (quoting the statute and placing it in a chronology of probation's development). As N.S. Timasheff argued, this law "merely gave stalutory sanction to the common-law practice of replacing punishment by recognizance for good behavior." 1 TIMASHEFF, supra note 387 , at $16 \mathrm{n} .2$. It did not embrace the peculiar procedural posture shared by the on-file mechanism and modern probation: The defendant is released after conviction but before sentence, so that the penalty for bad behavior is not merely forfeiting bonds, but being sentenced on the original indictment.

Second, I believe Grinnell attempted to minimize the degree of prosecutorial control over the on-file mechanism, especially in the early years. Although he acknowledged that Thacher's opinion in Chase made it clear that "the practice of suspending sentence was in fact by the consent of both parties to a case, because the govemment could move for sentence al any lime and the defendant also," Grinnell, supra note 300, at 631 . Grinnell argued that this fact "does not necessarily lead to the conclusion that the power of the Court rests upon the consent of the parties." Id. But as I argued earlier, see supra notes 363-366 and accompanying text. other language in Thacher's opinion suggests he thought the government's forbearance from moving for sentence was essential.

397. Commonwealth v. McGovern, 183 Mass. 238, 239 (1903).

398. Grinnell, supra note 300 , at 604 ; see also Harris, supro note 345 , at 120 ("The probation officer . . . becomes [the defendant's] surety for his appearance in coun when wanted.").

399. McGovern, 183 Mass. at 239. Although I am not sure, I believe that the court's reference to an "oral agreement made between [McGovern] and the Commonwealth." id., refers to an agreement with the probation officer, acting perhaps as a "fiduciary" of the court, id., rather than 
The near-complete identity of the "old" on-file mechanism and the "new" system of probation is apparent also in the record-keeping practices of Middlesex court clerks. As early as 1859 , the clerk's docket book entries often collapsed the concepts with the simple notation, "on file on probation." ${ }^{400}$ And as late as 1900, the clerk exclusively employed the "on file" formula. Although the record and docket books for that year list 212 cases as placed "on file" after a guilty finding and therefore functionally involving probation, the word "probation" appears not once. In 1903, cases that appear in the record book as being placed "on file" appear in the docket book as involving "probation." ${ }^{401}$ By 1910, the clerk had split the usual list of cases placed "on file" into two lists-one headed "on file," which presumably included those cases placed on file because a defendant or witness was missing, and the other headed "on probation." 402 Underneath the typewritten words, "on probation," that identified the second list, someone added in a neat script, "On file." ${ }^{403}$

But in one respect, the clerk's continued use of the term "on file" perhaps overstated the extent to which the procedures of probation remained frozen in time. A fair amount of evidence suggests that by the end of the century, the judge had more power than before to place a case on probation in the face of the district attorney's opposition. I have presented some of this evidence already: Over time, the clerk became more likely to write that "the Court" (rather than the prosecutor) had placed cases on file, and court rulings became less certain about whether the prosecutor's motion for sentence could compel the court to pass sentence. ${ }^{404}$ In addition, the probation statutes of the last quarter of the century tipped the balance of probationary power toward the court. Hence the 1878 act referred to "offenders placed on probation by the court"; 405 an 1880 act that extended this earlier law statewide said that " the court may permit the accused to be

with the district attorney. Elsewhere in the same paragraph, the court refers to both probation officer and prosecutor by title, so its ambiguous reference to an agreement with "the Commonwealth" seems odd. But as the court repeats the same ambiguous formula five times in its short opinion, see id. at 239-40, the word choice cannot have been unintended.

400. See, e.g., Commonwealth v. Charles McCannon, Middlesex Ct. C.P. Docket Book No. 656 (Feb. 1859) (on file with the Massachusetts Archives). I noted seven cases in the docket books of 1859 and two in the record books that explicitly equated putting a case on file and on probation in this manner.

401. See, e.g., Commonwealth v. George B. Avery, Middlesex Super. Ct. R. Book 316 (1903); Commonwealth v. George B. Avery, Middlesex Super. Ct. Docket Book No. 30 (1903); Commonwealth v. Thomas H. McNabb, Middlesex Super. Ct. R. Book 316 (1903); Commonwealth v. Thomas H. McNabb, Middlesex Super. Ct. Docket Book No. 61 (1903).

402. See Middlesex Super. Ct. R. Book 509, 513 (1910) (unpublished document, on file with the Massachusetts Trial Court).

403. Id. at 513.

404. See supra notes 323-325, 369-376 and accompanying text.

405. Act of Apr. 26, 1878, ch. 198, §1, 1878 Mass. Acts 146, 147 (providing for the probation of accused and convicted persons). 
placed upon probation, upon such terms as it may deem best" $;+106$ an act of 1891 gave lower-court justices the power to appoint probation officers, a power formerly vested in city officials, and said the court "may place [a convict] in the care of said probation officer for such time and upon such conditions as may seem proper" ${ }^{407}$ and an act of 1898 extended similar powers to superior-court judges. ${ }^{408}$

One can make too much of this apparent power shift. After all, the critical power sustaining on-file plea bargaining was the prosecutor's capacity to protect defendants from being sentenced by the court, which enabled him to extend a meaningful promise of leniency toward those defendants who pled guilty. ${ }^{409}$ Well into the twentieth century, it remained clear that without the prosecutor's motion, the court could not pass sentence. $^{410}$ Moreover, despite the Supreme Judicial Court's 1908 observation that "the principles which lie at the foundation of the [probation] legislation... seem to leave the whole matter in the control of the court," 411 there is some fairly weighty evidence that in practice the prosecutor retained substantial control. I quoted earlier from an 1899 report of Robert Harris, district attorney for the state's southern district. ${ }^{.12}$ Harris wrote the report specifically to explain "his doings" under the 1898 probation act, which seemed to place control over probation in the court's hands. "[T]he superior court may appoint probation officers," the Act declared, and the "court may place upon probation, under any of said probation officers, any person charged with a criminal offence." ${ }^{113}$ Harris reported that "[i]n 1898, I applied for the appointment of a probation officer, and my application was granted by his Honor, Mr. Justice Sherman." ${ }^{414}$ Remarkably, Harris continued in the first person: "I was fortunate in having at hand the man I selected [as probation officer]," 115 but "I made some mistakes, and placed some on probation who should not have been so treated." 416 That a superior-court judge so readily delivered up to the prosecutor the powers granted under the 1898 act is a strong hint that the power of probation up till then had lain in prosecutorial hands and that

406. Act of Mar. 22, 1880, ch. 129, $\$ 4,1880$ Mass. Acts 87, 87. In addition to providing for the appointment of probation officers, this act created the first parole-like regime in Massachusetts. See id. $\$ \S 6-10,1880$ Mass. Acts at 88-89; infra note 565 and accompanying text.

407. Act of May 28, 1891, ch. 356, § 3, 1891 Mass. Acts 920, 920 (providing for the appointment of probation officers).

408. See Act of June 8, 1898, ch. $511, \S 1,1898$ Mass. Acts 474, 474-75 (providing for the appointment of probation officers in the superior court).

409. See supra notes $322,336-358$ and accompanying text.

410. See supra notes 345-357 and accompanying text.

411. Marks v. Wentworth, 199 Mass. 44, 46 (1908).

412. See supra note 345 and accompanying text.

413. $\S 1,1898$ Mass. Acts at 475 .

414. Harris, supra note 345 , at 119.

415. Id. at 122.

416. Id. at 119 . 
the judge had little inclination to assume the chores that new power brought.

But parsing power in this way perhaps has little point in the context of turn-of-the-century probation. We have seen already that 225 of the 231 persons placed on probation in Middlesex in 1900 had pled guilty, ${ }^{417}$ so even if the judge had the power to impose probation over the prosecutor's objection, he was using probation as an instrument of plea bargaining no less than was the prosecutor. As we will see in Part V, by 1900 judges had become enthusiastic plea bargainers even outside the probation context. In California, where a 1903 probation statute gave judges both legal and actual power to decide which defendants received probation, ${ }^{418}$ probation served as a plea-bargaining tool as clearly as it did in Massachusetts. Lawrence Friedman and Robert Percival report in their study of Alameda County that thirty-one of thirty-two defendants who were placed on probation in their sample had pled guilty. ${ }^{419}$ So predictable was the court's practice that one defendant responded to a judge's inquiries, "I pleaded guilty because you can't try to get probation otherwise." 420 Probation, the authors conclude, "gave the guilty plea a powerful thrust." 421

It may be that by the turn of the century, the practice of probation in Massachusetts and California and probably many places in between had become so predictable that the power of probation as an instrument of plea bargaining was largely implicit - that is, that no defendant needed to be told that a guilty plea was the purchase price of the hope of probation. Friedman and Percival surely suspect as much. ${ }^{422}$ But as I hope this account of probation's upbringing in the state of its birth makes clear, probation's origins were coarser than that. From its first appearance in the opening third of the century, probation grew in the guise of on-file plea bargaining under the tutelage of prosecutors who often made quite plain the terms by which they would deal.

I do not suggest that probation never would have evolved but as the instrument of prosecutorial plea bargaining. Probation served the system well in many ways, not least by relieving prison overcrowding and

417. See supra text accompanying note 379.

418. See Act of Feb. 23, 1903, ch. 34, 1903 Cal. Stat. 34, 34 (" [T] he court shall have power. in its discretion, to place the defendant upon probation...."); FrIEDMAN \& PERCIVAL, supra note 135, at 227 (quoting from a 1910 sentencing hearing in which it was clear that the judge both held and wielded the decisionmaking power).

419. See FRIEDMAN \& PERCIVAL, supra note 135 , at 225 . They report that between 1900 and 1902 , just before the probation law passed, $32.2 \%$ of accused felons pled guilty, while $49.4 \%$ did so between 1903 and 1910. See id. at 227.

420. $I d$. at 227 (quoting from the 1910 sentencing hearing).

421. Id. at 226 .

422. They write: “Clearly, a guilty plea opened the doors to probation. Word of this must have gotten around to defendants and defense. The message- 'plead guilty" - rang through loud and clear." Id. at 181 . 
providing an appropriately mild punishment for first offenders, especially those who could not pay fines. My arguments are both far narrower and somewhat broader. The narrower argument impelled our recent descent into the morass of Massachusetts practice: Prosecutors were ready to exploit the power to plea bargain wherever they could find it. Massachusetts practice tossed them an unlikely scrap of power in barring judges from passing sentence until the prosecutor ceremonially moved for sentence. With this scrap, together with invention and industry, prosecutors built the covert regime of on-file plea bargaining. The broader argument looks at probation's rise as the first of several proofs of the larger power of plea bargaining as an institution. By the last quarter of the nineteenth century, plea bargaining had become a valued tool not only of prosecutors, but of judges as well. Serving the interests of all those with real power, plea bargaining became a dominant power by winning their protection. Prosecutors and judges protected plea bargaining by nurturing other procedural forms, such as probation, that helped plea bargaining thrive.

But we will return to the power of plea bargaining later. First we must examine how the powers and interests of defendants and judges helped to shape plea bargaining's rise.

\section{THE DEFENDANT'S POWER TO PLEAD}

As clear as their interest in plea bargaining may have been, prosecutors' power to bargain was well-hidden, and tracking it has absorbed a good many pages. In contrast, criminal defendants had both a clear incentive and a clear capacity to plea bargain. Their incentive lay in the difference between the severe sentence that loomed should the jury convict at trial and the more lenient sentence promised by the prosecutor or judge in exchange for a plea. At first glance, the intensity of defendants' desire to plead appears to have been a simple function of the power and inclination of the prosecutor or judge to widen this difference. And defendants' power to plead was even clearer and more constant: As the holders of the right to a jury trial, they held the power to waive it. Even when a defendant pled guilty to a capital charge and thereby assured his own execution, the "court ha[d] no power absolutely to refuse" his plea. ${ }^{423}$

423. Green v. Commonwealth, 94 Mass. (12 Allen) 155, 176 (1866). Green was at least the second time the Supreme Judicial Cour addressed guilty pleas in capital cases. In the first. Commonwealth v. Batris, 1 Mass. (1 Will.) 94 (1804), the defendant already had been execuled at the time of the court's opinion, and the court did not review the legality of the proceedings. Since the defendant had pled guilty before the high cour, however. and since three justices of that court must have passed the death sentence, see MENAND, supra note 5, at 37, there is no reason to think that the court disapproved of the proceedings. The Bartis trial coun did take great care to give the defendant a chance to reconsider his self-destructive plea, and in Green the court wrote that "[i]t is the well settled practice in all courts ... to receive and record with great reluctance and caution 
We therefore might be tempted to dismiss defendants as mathematical constants to be factored out of our plea-bargaining equation and to concentrate instead on the variables of prosecutor and judge, were it not for some stubborn evidence that defendants' inclination to plea bargain was not constant after all. Defendants' fundamental preference for the mildest punishment possible remained in place, of course. But their power to win at trial—or at least their perception of that power-rose in one period and fell in the next. And as their hopes of walking free after trial first brightened and then faded, their willingness to plead guilty diminished and grew.

I will focus here on two developments in trial practice that may have altered defendants' views of their power to win at trial. The first is an apparent increase during the first half of the nineteenth century in the proportion of defendants who came before the courts of the middle tier with counsel. Lawyers probably raised these defendants' chances of victory at trial and dulled their enthusiasm to plead. The second is the advent of laws during the second half of the century that gave defendants the right to testify at trial. These defendant-testimony laws may have had the unexpected result of persuading some defendants that their odds of victory were dismal and that a good bargain was their best hope. Unfortunately, because defendants left behind even sparer records than prosecutors of their thoughts and fears, reconstructing their motives will require us at times to take long steps between widely spaced flagstones of evidence.

\section{A. The Power of Representation}

The court records of Middlesex County disclose this surprising news: At the very outset of the nineteenth century, about two-thirds of the cases that came before the courts of the middle tier ended in guilty pleas. Figure 4 shows the proportion of adjudicated non-liquor cases that ended in a plea of guilty or no contest in the Court of General Sessions of the Peace, the Court of Common Pleas, and the Superior Court, each of which in its era had jurisdiction to try many or most noncapital offenses ${ }^{424}$ From an initial high of seventy-one percent in 1789-1790, the rate of pleas fell sharply if not

a confession of guilt in a capital cause." Green, 94 Mass. (12 Allen) at 175-76. But as I noted in the text, the court denied itself the power to refuse such a plea.

424. "Adjudicated cases" are those in which the defendant went to trial or pled guilty or no contest. I have excluded from Figure 4 both liquor cases and cases placed on filc to avoid the distorting impact of the large shifts in prosecutorial plea bargaining power that we saw in Parts I and III. Moreover, for comparisons that span the century, it is important to keep the mix of case types relatively stable. As so-called "filed" cases did not appear until the 1840s, see supra notes 304-312 and accompanying text, and as liquor cases were quite rare in the first decades of the century, see supra note 44 and accompanying text, including them could badly distort some findings. 
Figure 4. PROPORTION OF CASES ENDING IN A PLEA OF GUILTY OR NO CONTEST (ADJUDICATED NON-LIQUOR, NON-FILED CASES ONLY): MIDDLESEX COUNTY SUPERIOR COURT AND ITS PREDECESSOR COURTS

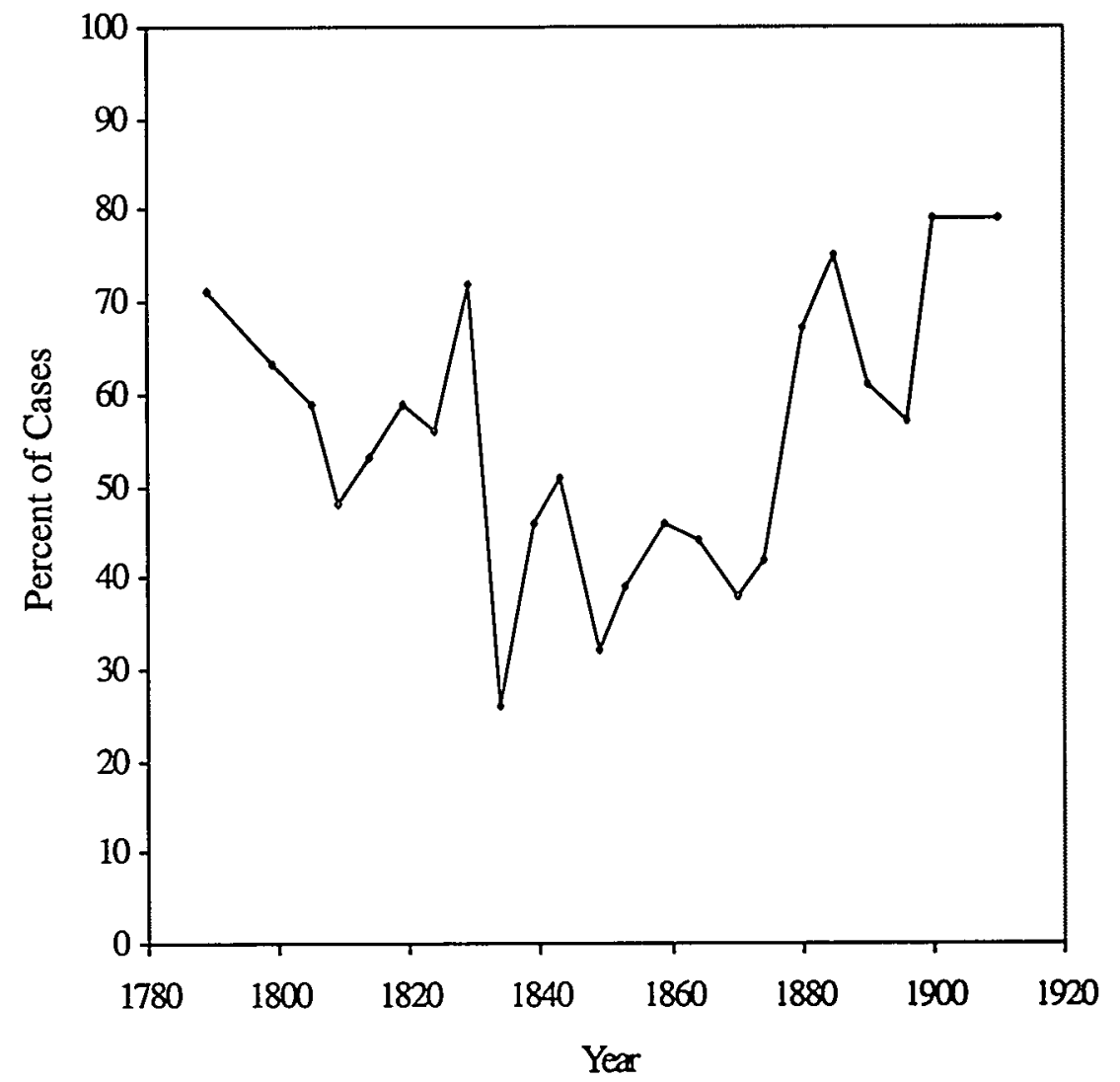

steadily until it reached a low of twenty-six percent in 1834 . Guilty pleas remained comparatively rare until the late 1870 s, when they began their long upswing toward the full-fledged plea bargaining regime that closed the century.

I call the news that the century began with a strikingly high rate of guilty pleas surprising because most scholarship suggests not merely that guilty pleas were rare before the middle of the nineteenth century, but also that courts refused or were reluctant to accept them. ${ }^{425}$ But it appears that

425. See, e.g., Alschuler, supra note 2, at 5-16, 19-24; Vogel, supra note 146, at 52 (“- [T] courts, at the beginning of the [19th] century were reluctant to accept a guilty plea under any circumstances."); Michael Jonathan Millender, The Transformation of the American Criminal Trial, 1790-1875, at 187 (1996) (unpublished Ph.D. dissertation. Princeton University) (on file with the Stanford Law School Library) ("Even in the North. courts . . a the beginning of the nineteenth century... only reluctantly accepted guilty pleas."): see also John H. Langbein. Understanding the Short History of Plea Bargaining, 13 L. \& SOC'Y REV. 261, 264 (1979) (writing of the early 18th century that not only was there "no particular pressure to . . . encourage the accused to waive his right to jury trial," but "the sources reveal an opposite pressure"). 
this reluctance was limited largely to capital cases. As a Massachusetts defense lawyer argued in 1866 in seeking to undo a guilty plea in a capital case, such a plea "is suicide, commited under the color of law." 426 The Supreme Judicial Court rejected this argument and ratified the defendant's death sentence, but did acknowledge that courts receive "a confession of guilt in a capital cause" with "great reluctance." 427 In 1877, a former Massachusetts judge and governor wrote that although courts readily accepted guilty pleas in most cases, "in Massachusetts ... the court will not receive a plea of guilty to an indictment for murder until after a full advisement of the prisoner of the consequences of such a plea." ${ }^{428}$ In fact, guilty pleas to capital charges-with no reduction to a noncapital offensewere rare. I have found only five throughout the century. ${ }^{429}$

But concerns about judicial suicide had no weight in noncapital cases. Perhaps we should not be surprised, therefore, by the very high rates of guilty pleas in the courts of the middle tier, where no capital case was heard. ${ }^{430}$ Yet the news is surprising for another reason: Even as the rate of guilty pleas was falling in the first third of the century, the caseload of the middle-tier courts was rising, sometimes sharply. At the very moment the rate of guilty pleas fell to its 1834 low, the court's caseload leapt from forty-one cases in 1829 to ninety-five cases in $1834 .{ }^{431}$ Lower plea rates and a larger caseload translated into what must have been a shocking increase in the number of trials-from six trials of all sorts in 1829 to forty-six in 1834 and as Figure 5 shows, the number of trials continued unevenly upward.

426. Green, 94 Mass. (12 Allen) at 158.

427. Id. at 176. In the latter half of the 18th century, Blackstone explained the judicial suspicion toward guilty pleas specifically in the capital context: "Upon a simple and plain confession, the court hath nothing to do but to award judgment: but it is usually very backward in receiving and recording such confession, out of tenderness to the life of the subject; and will generally advise the prisoner to retract it ..." 4 WILLIAM BLACKSTONE, COMMENTARIES *329. Likewise, in the mid-17th century, Hale suggested that judges encouraged capital defendants in particular to go to trial rather than plead guilty. See 2 MATTHEW HALE. HiSTORY OF THE PLEAS OF THE CROWN 225 (Philadelphia, Robert H. Small 1847) ("[B]ut it is usual for the court. especially if [the crime] be out of clergy [i.e., capital], to advise the party to plead and put himself upon his trial ....").

428. EMORY WASHBURN, A MANUAL OF CRIMINAL LAW at vi, 132 (3d ed. 1900); see also DAVIS, supra note 7, at 247-48 (providing biographical information about Washburn). After this quotation, Washburn cited to Commonwealth v. Battis, 1 Mass. (1 Will.) 94 (1804), which involved a guilty plea in a murder case. Washburn's reliance on Battis suggests that Battis should not be interpreted as evidence that Massachusetts judges were suspicious of all guilty pleas.

429. See supra note 91 .

430. As an Ohio court wrote in 1892, there is no reason to expect that an old notion that courts should resist a defendant's desire to plead guilty, which "had its origin at a period in the history of the law of England when offenses that would now be regarded as comparatively trivial, were, upon conviction, visited with death," should have much impact in a noncapital American court of a later age. Craig v. State, 49 Ohio St. 415, 416 (1892).

431. See supra note 126. 
FIGURE 5. NUMBER OF TRIALS:

MIDDLESEX COUNTY SUPERIOR COURT AND ITS PREDECESSOR COURTS

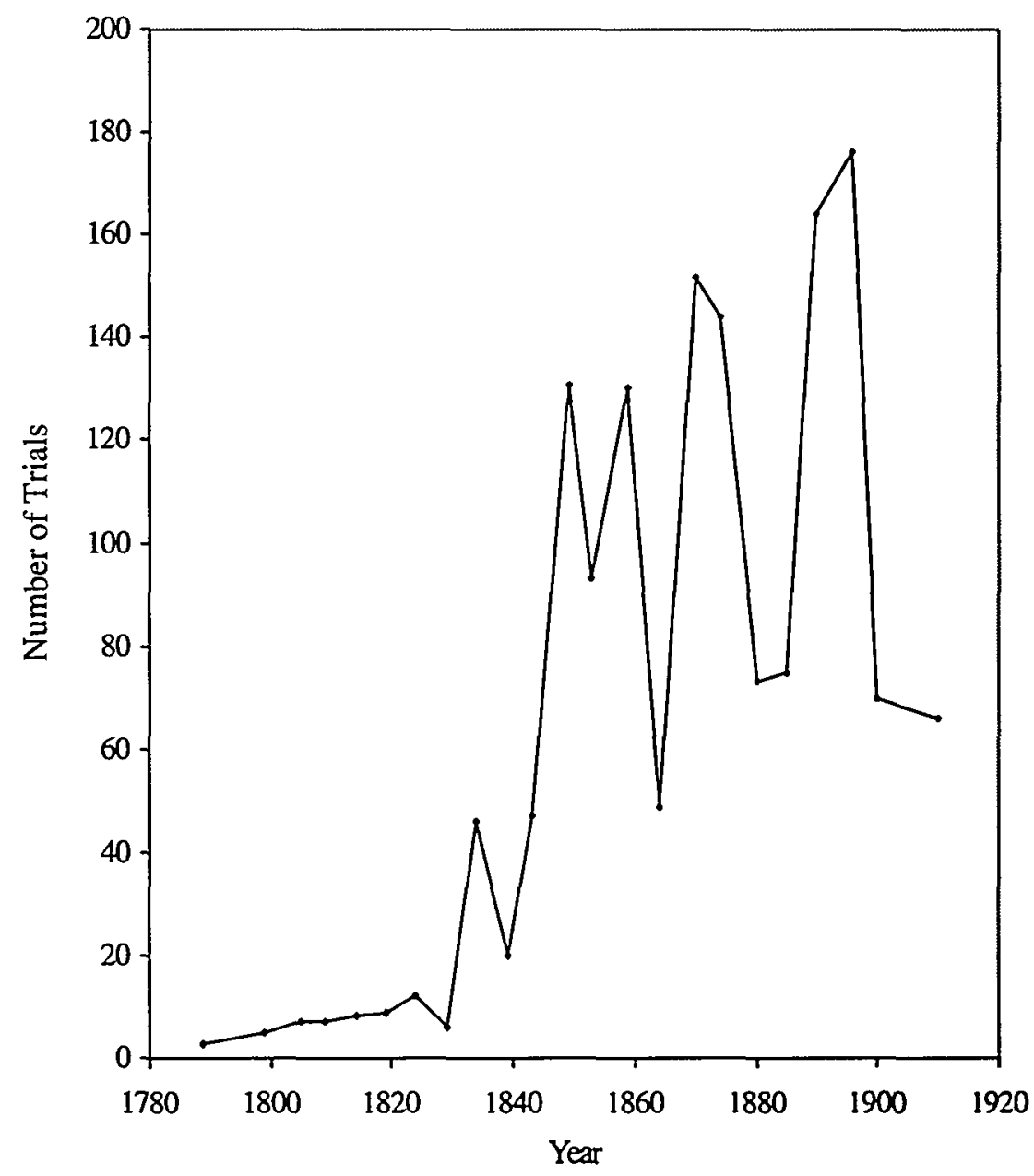

I argued in Part II that caseload pressure helped motivate prosecutors to develop their charge-bargaining techniques in liquor cases, and $\mathrm{I}$ will argue in Part V that caseload pressure helped win judges over to plea bargaining's cause in the latter part of the century. Still, it is not entirely paradoxical that rising caseload pressure did not translate into increased plea bargaining in the first third of the century. I have excluded liquor cases from Figure 4 to avoid the distorting impact of the prosecutor's unusual power to charge bargain in liquor cases. In other cases, as I have argued, ${ }^{432}$ prosecutors simply lacked the power to escape a rising caseload by plea bargaining. ${ }^{433}$

432. See supra notes $41-44$ and accompanying text.

433. Prosecutors did have in all cases the power to set costs, and as I noted carlicr, costs typically were higher after trial than after a plea. See supra notes $41,47-50$ and accompanying 
As for judges, we have seen that the peculiar features that made the caseload boom of the last quarter of the century so persuasive to them of the need for plea bargaining were not yet in place during the century's first decades. ${ }^{434}$

The real paradox emerges from these last two facts: If prosecutors lacked the ability to plea bargain and if judges lacked the interest, then why did so many defendants plead guilty in the first decades of the nineteenth century? These pleas were not, after all, plea bargains that involved a concession made in exchange for the defendant's plea-my analysis of sentencing patterns in Part II showed as much. To explain these pleas, then, I suggest we shift our focus from prosecutor and judge and ask what might have persuaded defendants to plead guilty even when they could expect no concession in return.

In particular, I suggest that we consider the role of defense counsel. If very few defendants came to court with counsel in 1789 and an increasing proportion did so thereafter, that alone could explain both the high rate of guilty pleas at the outset and the drop in guilty pleas over the first third of the century. Before fleshing out this hypothesis, I should expose its weakest joint: None of my evidence discloses how many defendants brought counsel to court in this period. The record books of the middle-tier courts in Middlesex County almost never noted counsel, and the docket books began to do so only in 1844. I have found no other study that reports the rate of counsel appearances in any Massachusetts court in the early nineteenth century or before. ${ }^{435}$

In terms of direct evidence of the prevalence of counsel, therefore, we have to be content with what the docket books tell us about 1844 and later. At least at first glance, this information gives only mild support to my hypothesis that representation by counsel was rising over the first decades of the century. In 1844, fifty-one percent of defendants came to court with counsel, a number that advanced modestly to sixty percent by 1849 . Thereafter, the rate of representation varied within fairly narrow bounds throughout the balance of the century, never again hitting the 1849 high of

text. It is very hard to say how effectively prosecutors could have wielded the cost-setting power as a plea-bargaining tool in the general run of cases. The court never ordered costs against defendants who were found not guilty after trial and very rarely did so against defendants sentenced to serve time. Defendants who went to trial therefore had a good chance of escaping costs altogether. The prosecutor's power to set costs probably worked best as a plea-bargaining tool in cases that were likely to be punished by a fine-among them, liquor cases.

434. See infra notes 184-197 and accompanying text.

435. Mary Vogel, who studied lower-tier courts only, see supra note 223 and accompanying text, where defense counsel probably were rarer, see FERDINAND, supra note 121 , at 81 , does not speak much about counsel. Theodore Ferdinand reports that the records of the Boston Municipal Court do not systematically record counsel, though as I noted earlier, it seems possible that he did not use the court's docket books as a source. See supra note 222. 
sixty percent, but also never dropping past the 1880 low of forty-one percent. ${ }^{436}$

Still, there are at least two reasons to believe that the rate of representation was in fact growing through the first third of the century. The first is that an ocean away, at London's Old Bailey court, the rate of representation seems to have risen sharply from less than ten percent in 1815 to just shy of fifty percent, or about the same rate as in Middlesex County, in $1855 .{ }^{437}$ The second is the suddenness of the transformation that took place in Middlesex County between 1829 and 1834, when the caseload of the Court of Common Pleas more than doubled at the same time that the rate of pleas fell by almost two-thirds. The most likely explanation for the leap in caseload is an 1832 statute that transferred the bulk of the Supreme Judicial Court's criminal trial jurisdiction to the Court of Common Pleas. ${ }^{438}$ We can expect that along with more serious cases, this transfer of jurisdiction brought with it the lawyers who used to handle those cases before the Supreme Judicial Court.

Unfortunately, that court's record and docket books, like those of the Court of Common Pleas, do not disclose the proportion of defendants that had counsel in these early years. But the gravity of both the tribunal and the crimes charged makes it seem likely that cases heard before the Supreme Judicial Court typically involved defense counsel. In capital cases, the court appointed free counsel. When charged with other crimes that called for long sentences, defendants may have felt it more worthwhile than usual to spend their own funds. ${ }^{439}$ If it is true that cases transferred from the Supreme

436. I measured the following representation rates:

\begin{tabular}{|c|c|}
\hline 1844 & $51 \%$ \\
\hline 1849 & $60 \%$ \\
\hline 1853 & $54 \%$ \\
\hline 1859 & $52 \%$ \\
\hline 1864 & $54 \%$ \\
\hline 1870 & $58 \%$ \\
\hline 1880 & $41 \%$ \\
\hline 1900 & $46 \%$ \\
\hline
\end{tabular}

Sources: Middlesex Ct C.P. R. Books; Middlesex Ct. C.P. Docket Books; Middlesex

Super. Ct. R. Books; Middlesex Super. Ct. Docket Books.

437. See Malcolm M. Feeley \& Charles Lester, Legal Complexiry and the Transformation of the Criminal Process, in SUBJEKTIVIERUNG DES JUSTIZIELLEN BEWEISVERFAHRENS 337. 355 (Andre Gouron et al. eds., 1994). This study provides "tentative" suppon not only because its setting is an ocean away, but also because the authors repon an anomalously high rate of representation in 1795-about 40\% - that internupts very low rates that prevailed throughout the 18th century and in 1815. The authors suggest no explanation for their discordant figures in 1795 . See id.

438. See supra note 125 and accompanying text.

439. Although Massachusetts law provided for free counsel in capital cases, it made no provision for indigents accused of lesser crimes, and as late as 1952, appointed counsel were confined to cases of first-degree murder. See Marin V. Callagy. Legal Aid in Criminal Cases, 42 J. CRIM. L. CRIMINOLOGY \& POLICE SCI. 589. 611 (1952). New York apparently provided free 
Judicial Court to the Court of Common Pleas brought a new contingent of defense counsel with them, then these lawyers probably carried along a culture in which trials were more the norm and guilty pleas more the exception. For although the rate of pleas in the Supreme Judicial Court exceeded one-half in 1799 and one-third in 1824, it generally was much lower than in the Court of Common Pleas. It stood at just ten percent in 1829 , the last year I studied before the jurisdiction shift, when the rate of pleas in the Court of Common Pleas was a remarkable seventy-two percent. $^{440}$

Of course, a higher rate of trials in the upper court could be due less to the presence of lawyers than to the seriousness of the crimes tried there and the unlikelihood that a defendant would plead guilty in the face of a long prison term. But statistics from the Court of Common Pleas in 1844 and later, when the court's docket books permit us to see the presence of lawyers, suggest that counsel in fact did influence the defendant's choice between trial and plea. Especially in the middle of the century, defendants with lawyers were a good deal more likely to choose trial than were defendants without lawyers. ${ }^{441}$ If we add to this fact three others, we can

counsel to all indigent defendants at least by 1810 , and almost all defendants therefore had lawyers. See McConville \& Mirsky, supra note 243, at 454-55.

440. These are my findings for the years before the 1832 jurisdiction shift:

DISPOSITION BY PLEA OF GUILTY OR NO CONTEST IN THE SUPREME JUDICIAL COURT

(SITTING IN MIDDLESEX COUNTY)

\begin{tabular}{|c|c|c|c|}
\hline YEAR & $\begin{array}{c}\text { NUMBER OF } \\
\text { ADJUDICATED CASES }\end{array}$ & NUMBER OF PLEAS & $\begin{array}{c}\text { PERCENTAGE OF } \\
\text { PLEAS }\end{array}$ \\
\hline 1799 & 11 & 6 & $55 \%$ \\
\hline 1809 & 22 & 2 & $9 \%$ \\
\hline 1819 & 27 & 8 & $30 \%$ \\
\hline 1824 & 32 & 12 & $38 \%$ \\
\hline 1829 & 20 & 2 & $10 \%$ \\
\hline
\end{tabular}

Sources: Middlesex Ct. C.P. R. Books; Middlesex Ct. C.P. Docket Books; Middlesex Super. Ct. R. Books; Middlesex Super. Ct. Docket Books.

After the jurisdiction shift, there were too few cases left in the Supreme Judicial Court to allow for meaningful analysis. See supra note 125 and accompanying text.

441. My findings are as follows:

PROPORTION OF ADJUDICATED DEFENDANTS WHO CHOSE TRIAL OVER PLEA: MIDDLESEX COURT OF COMMON PLEAS AND SUPERIOR COURT

\begin{tabular}{|c|c|c|}
\hline YEAR & WITH COUNSEL & WITHOUT COUNSEL \\
\hline 1844 & $64 \%$ & $39 \%$ \\
\hline 1849 & $58 \%$ & $43 \%$ \\
\hline 1853 & $77 \%$ & $48 \%$ \\
\hline 1859 & $68 \%$ & $45 \%$ \\
\hline 1864 & $36 \%$ & $29 \%$ \\
\hline 1870 & $53 \%$ & $49 \%$ \\
\hline 1880 & $26 \%$ & $21 \%$ \\
\hline 1900 & $14 \%$ & $13 \%$ \\
\hline
\end{tabular}

Sources: Middlesex Ct. C.P. R. Books; Middlesex Ct. C.P. Docket Books; Middlesex Super. Ct. R. Books; Middlesex Super. Ct. Docket Books. 
arrive at a theory about why a rising rate of representation in the Court of Common Pleas in the first decades of the century might have produced not only a falling rate of guilty pleas, but also strong pressure to develop a pleabargaining regime.

The first additional fact is that defendants who chose trials were consistently more likely to win if they had lawyers. ${ }^{+12}$ The second is that defendants who chose instead to plead guilty were usually more likely to get clear plea bargains-either charge bargains or on-file plea bargains-if they had lawyers. ${ }^{443}$ And finally, to cast this last fact in a slightly different light, defendants with lawyers were far less likely to plead guilty without an apparent concession, as opposed to either plea bargaining or going to trial,

Some uncertain corroboration for my finding that cases with lawyers were more likely to go to trial comes from McConville and Mirsky's work in New York. They report both near-universal representation by counsel at the beginning of the century and a rate of trials that fell just below 80\%. See McConville \& Mirsky, supra note 243, at 454, 466; see also Clara Foltz, Public Defenders, 31 AM. L. REV. 393, 393 (1897) (arguing that many unrepresented defendants " are recorded as pleading guilty and railroaded into jail because too dazed to understand their rights and legal position").

442. My findings are as follows:

INFLUENCE OF COUNSEL ON TRLAL VICTORY RATE: MIDDLESEX COURT OF COMMION PLEAS AND SUPERIOR COURT

\begin{tabular}{|c|c|c|}
\hline \multirow{2}{*}{ YEAR } & \multicolumn{2}{|c|}{ PERCENTAGE OF DEFENDANTS WHO WON } \\
& \multicolumn{2}{|c|}{ ACQUITTALS OR HUNG JURIES } \\
\cline { 2 - 3 } & WITH COUNSEL & WITHOUT COUNSEL \\
\hline 1844 & $17 \%$ & $15 \%$ \\
\hline 1849 & $48 \%$ & $13 \%$ \\
\hline 1853 & $44 \%$ & $22 \%$ \\
\hline 1859 & $49 \%$ & $25 \%$ \\
\hline 1864 & $54 \%$ & $43 \%$ \\
\hline 1870 & $38 \%$ & $20 \%$ \\
\hline 1880 & $40 \%$ & $8 \%$ \\
\hline 1900 & $59 \%$ & $38 \%$ \\
\hline
\end{tabular}

Sources: Middlesex Ct. C.P. R. Books; Middlesex Ct. C.P. Docket Books; Middlesex Super. Ct. R. Books; Middlesex Super. Ct. Docket Books.

443. My findings are as follows:

PROPORTION OF DEFENDANTS OFFERING PLEAS WhO WON ClEAR PLEA BARGaINS: MIDDLESEX COURT OF COMMON PLEAS AND SUPERIOR COURT

\begin{tabular}{|c|c|c|}
\hline YEAR & WITH COUNSEL & WITHOUT COUNSEL \\
\hline 1844 & $18 \%$ & $23 \%$ \\
\hline 1849 & $66 \%$ & $31 \%$ \\
\hline 1853 & $33 \%$ & $42 \%$ \\
\hline 1859 & $64 \%$ & $31 \%$ \\
\hline 1864 & $57 \%$ & $51 \%$ \\
\hline 1870 & $36 \%$ & $19 \%$ \\
\hline 1880 & $36 \%$ & $33 \%$ \\
\hline 1900 & $55 \%$ & $53 \%$ \\
\hline
\end{tabular}

Sources: Middlesex Ct. C.P. R. Books; Middlesex Ct. C.P. Dockeı Books; Middlesex Super. Ct. R. Books; Middlesex Super. Ct. Docket Books. 
than were defendants without lawyers ${ }^{44}$-a pattern Friedman and Percival found repeated some decades later and a continent away in Alameda County. ${ }^{445}$

A theory of the early years now emerges that helps to explain what came later. Defendants without lawyers, who (I will assume) accounted for the great majority of defendants in the beginning of our period, correctly saw that their chances of winning at trial were quite poor-generally no better than twenty-five percent and in some years worse. ${ }^{446}$ Lacking the shrewdness to press for a sentencing concession in exchange for their guilty pleas, these unrepresented defendants simply pled to the charges they faced, ${ }^{447}$ hoping, perhaps without reason, that the judge might show leniency as a reward for their pleas. As defendants grew more likely to have counsel, they saw their chances of winning at trial increase to more than forty percent in most years and to more than fifty percent in some. At that point, they had less regard for the option of throwing themselves on the court's mercy, and their counsel advised them instead to demand some sort

444. My findings are as follows:

PROPORTION OF ADJUDICATED DEFENDANTS WHO PLED WITHOUT APPARENT CONCESSION: MIDDLESEX COURT OF COMMON PLEAS AND SUPERIOR COURT

\begin{tabular}{|c|c|c|}
\hline YEAR & WITH COUNSEL & WITHOUT COUNSEL \\
\hline 1844 & $30 \%$ & $47 \%$ \\
\hline 1849 & $15 \%$ & $39 \%$ \\
\hline 1853 & $15 \%$ & $30 \%$ \\
\hline 1859 & $12 \%$ & $38 \%$ \\
\hline 1864 & $27 \%$ & $35 \%$ \\
\hline 1870 & $30 \%$ & $41 \%$ \\
\hline 1880 & $47 \%$ & $53 \%$ \\
\hline 1900 & $39 \%$ & $41 \%$ \\
\hline
\end{tabular}

Sources: Middlesex Ct. C.P. R. Books; Middlesex Ct. C.P. Docket Books; Middlesex Super. Ct. R. Books; Middlesex Super. Ct. Docket Books.

445. See Friedman \& PERCIVAl, supra note 135, at 174 (noting that "[m]ost" defendants who pled guilty at arraignment had waived counsel). Friedman and Percival cite a survey of inmates at Folsom Prison taken in the late 1880 s in which $33.9 \%$ of those who pled guilty said that they did so because they "had neither money nor friends." THE STATE BD. OF PRISON DIRS. OF THE STATE OF CAL., EIGHTH ANNUAL REPORT 88 (Sacramento, J.D. Young 1887), cited in FRIEDMAN \& PERCIVAL, supra note 135 , at $180 \mathrm{n} .77$. It is hard to imagine the relevance of the lack of money and friends except that, without either, one cannot hire a lawyer. As California defendants were entitled to free counsel in felony trials after 1872, see CAL. PENAL CODE $§ 987$ (Sumner Whitney \& Co. 1881), it is a puzzle why a defendant would plead guilty for want of counsel. But since appointed counsel got no fees, see FrIEDMAN \& PERCIVAL, supra note 135, at 172 , defendants may have been correct in believing that they got what they paid for. See id. at 202 (presenting data suggesting that appointed counsel were less zealous in their work than paid counsel).

446. Cf. Foltz, supra note 441, at 397 ("[The defendant] does know that to go into court without counsel would be equivalent to an invitation to convict which a jury would readily accept.").

447. See Langbein, supra note 425 , at 269 n.12 ("Where assigned counsel was not readily available, an indigent accused in nineteenth-century America may have had a considerable incentive to plead guilty rather than try to defend himself at trial ... against a lawyer-public prosecutor."). 
of guaranteed concession in exchange for their pleas. Meanwhile, prosecutors chafed at their increasing trial loads. What was worse, the cases that they were most likely to lose because of the opposition of defense counsel were for the same reason the most time-consuming to try. ${ }^{4+18}$ Prosecutors badly wanted more cases to plead out, yet they had a hard time persuading defendants with counsel to plead guilty without guaranteeing them something in return.

Of course, the power of prosecutors to grant meaningful concessions extended only to charge bargaining in liquor cases (which happened to have a substantially higher rate of counsel representation than other cases $)^{4+9}$ and to their promise not to move for sentence in the course of on-file plea bargains. Prosecutors lost their power to charge bargain in liquor cases when the legislature banned nol prosses without the court's approval in $1852 .{ }^{450}$ Because on-file plea bargaining involved letting the defendant go in the first instance, that option was inappropriate for the more serious cases on the docket. So despite the great pressure put on prosecutors by the large number of trials in the middle decades of the century, the rate of guilty pleas remained low for some time.

The records of capital pleas before the Supreme Judicial Court reveal a similar dynamic of interests and constrained options at work. I noted earlier that it was unclear until 1838 whether prosecutors had the power to enter partial nol prosses to reduce, for example, murder to manslaughter or rape to assault with intent to rape. ${ }^{451}$ In any event, no such reduction appears in the records before 1841 . It is hardly surprising, therefore, that virtually

448. In 1844, while complaining about his recently diminished salary. Suffolk County attomey Samuel D. Parker noted, "The labor of the trials is increased by the increased attendance of very eminent counsel in the defences." S. Doc. No. 68, at 7 (Mass. 1844) (petition of Samuel D. Parker).

449. My findings are as follows:

PROPORTION OF LIQUOR AND NON-LIQUOR DEFENDANTS WITH COUNSEL: MIDDLESEX COURT OF COMMON PLEAS AND SUPERIOR COURT

\begin{tabular}{|c|c|c|}
\hline YEAR & LIQUOR-LICENSE DEFENDANTS & NON-LIOUOR DEFENDANTS \\
\hline 1844 & $62 \%$ & $40 \%$ \\
\hline 1849 & $68 \%$ & $58 \%$ \\
\hline 1853 & $72 \%$ & $31 \%$ \\
\hline 1859 & $59 \%$ & $48 \%$ \\
\hline 1864 & $64 \%$ & $52 \%$ \\
\hline 1870 & $59 \%$ & $53 \%$ \\
\hline 1880 & $57 \%$ & $36 \%$ \\
\hline 1900 & $81 \%$ & $44 \%$ \\
\hline
\end{tabular}

Sources: Middlesex C. C.P. R. Books; Middlesex C. C.P. Docket Books; Middlesex Super. Ct. R. Books; Middlesex Super. Ct. Docket Books.

450. See Act of May 22, 1852, ch. 322, §13, 1852 Mass. Acts 257, 257.

451. See supra notes $107-115$ and accompanying text. 
every capital defendant went to trial, for a guilty plea simply guaranteed death. $^{452}$

It is more surprising that even after capital charge bargains appeared in 1841 , they remained rather rare for two decades, accounting for only ten percent of adjudicated capital cases in the 1840s and seventeen percent in the 1850s. One possible reason for their lingering scarcity emerges from an examination of the results at capital trials. It appears that in the 1830s and 1840 s, the attorney general had a dismal record of success at trial. In the 1830 s, there were more than three times as many acquittals or hung juries as capital murder convictions, and in the 1840 s, almost twice as many.

\section{TABLE 4. OUTCOMES OF CAPITAL TRIALS BEFORE THE SUPREME JUDICIAL COURT ${ }^{453}$}

\begin{tabular}{|c|c|c|c|c|c|}
\hline Years & $\begin{array}{c}\text { Number of } \\
\text { Trials }\end{array}$ & $\begin{array}{c}\text { Percent } \\
\text { Convicted } \\
\text { of Capital } \\
\text { Murder }\end{array}$ & $\begin{array}{c}\text { Percent } \\
\text { Convicted } \\
\text { of Second- } \\
\text { Degree } \\
\text { Murder }\end{array}$ & $\begin{array}{c}\text { Percent } \\
\text { Acquittals } \\
\text { or Hung } \\
\text { Juries }\end{array}$ & $\begin{array}{c}\text { Percent } \\
\text { Charge } \\
\text { Bargains }\end{array}$ \\
\hline $1820-1829$ & 16 & 38 & N/A & 31 & 0 \\
\hline $1830-1839$ & 45 & 20 & N/A & 64 & 0 \\
\hline $1840-1849$ & 37 & 27 & N/A & 49 & 10 \\
\hline $1850-1859$ & 35 & 40 & 11 & 29 & 17 \\
\hline $1860-1869$ & 28 & 39 & 14 & 32 & 47 \\
\hline $1870-1879$ & 45 & 31 & 24 & 27 & 43 \\
\hline $1880-1889$ & 34 & 24 & 41 & 24 & 35 \\
\hline $1890-1899$ & 27 & 33 & 26 & 37 & 61 \\
\hline
\end{tabular}

Sources: Annual Reports of the Attorney General; Sup. Jud. Ct. R. Books: Sup. Jud. Ct. Docket Books.

With so great a chance of escaping conviction altogether and so small a chance of going to the gallows (shrunk even further by occasional commutations), a typical defendant might well have spurned a guilty plea to take his chances at trial.

The situation changed dramatically in the 1850 s. Suddenly, capital defendants were almost twice as likely to be convicted of some form of murder as to escape conviction altogether. And suddenly, a manslaughter plea must have seemed a far more desirable outcome. What brought about this change in fortunes is not clear. Certainly the option of returning a 91.

452. I found only five such pleas to capital charges throughout the century. See supra note

453. Figures for 1820-1832, 1840-1848, and 1853 are based on surveys of the court's business. See supra notes $92,97,99$. 
second-degree murder conviction, available in 1858 and later, must have reduced the number of hung juries and manslaughter convictions. Improved policing - the Boston Police Department appointed its first detectives in $1846^{454}$ and resulting improvements in evidence-gathering must have helped as well. In any event, these ratios remained largely in place throughout the rest of the century: The chances of a murder conviction were always substantially greater than the combined odds of an acquittal or a hung jury. Although we might not expect that the rate of guilty pleas would respond immediately to outcomes at trial, we would expect to see such a response within a few years. Defense counsel, present in every capital case, must have warned clients of the unlikelihood of winning at trial when advising them whether to strike a deal. So perhaps as a result of the attorney general's improved performance at trial, the proportion of charge bargains in capital cases grew dramatically to forty-seven percent of adjudicated murder cases in the 1860s and then hovered between thirty-five percent and sixty-one percent for the balance of the century.

In the courts of the middle tier, however, the rate of guilty pleas remained low through most of the middle third of the nineteenth century. Stripped of the power to charge bargain in liquor cases and lacking it in other cases, prosecutors could not promise the kind of sentencing concessions that would entice defendants to plead guilty. Yet during the last quarter of the century, the rate of guilty pleas grew strikingly. Two causes may have been at work. The first was the legislature's decision to let defendants testify at trial, which had the ironic result of persuading some defendants that trial was hopeless and that a guilty plea-even one unsecured by a promised concession-was their only option. Second, the weight of an unremitting trial load began to press upon judges, who had far broader powers than prosecutors to make concessions. This latter development will be the focus of Part V. The former I take up now.

\section{B. The Impact of Defendant-Testimony Laws}

In 1866 Massachusetts became the third state in the nation to grant defendants the right to testify on their own behalf. .ss $^{\text {Th }}$ The next year, Judge Seth Ames of the superior court scoffed at the idea that the new law would help defendants. Ames, who would rise to the Supreme Judicial Court in 1869,456 argued that the law left the defendant with two unpleasant alternatives. First, he could choose silence and face almost inevitable

454. See LANE, supra note 4 , at 60.

455. See Act of May 26, 1866, ch. 260, 1866 Mass. Acts 245, 245. The first two states to pass such acts were Maine and California. See Act of Apr. 2, 1866, ch. 644, $\$ 1$ 1. 1866 Cal. Stat. 865, 865; Act of Mar. 25, 1864, ch. 280, § 1, 1864 Me. Laws 214, 214.

456. See DAVIS, supra note 7, at 194-95. 
conviction. True, the law declared that the defendant could testify "at his own request, but not otherwise" and guaranteed that "neglect or refusal to testify shall not create any presumption against" him, ${ }^{457}$ but these were "fallacious and idle" words. ${ }^{458}$ "[T]he jurors all know," Ames wrote, "that the defendant has the privilege (as it is called) of making himself a witness if he sees fit; and they also know that he would if he dared." 459 Therefore, his silence "will, and inevitably must, create a presumption against him, even if every page of the statute-book contained a provision that it should not. The statutes might as well prohibit the tide from rising ...." 460 In short, if the defendant "should decline to make himself a witness, the jury would convict him without leaving their seats." ${ }^{461}$ And so this law permitting defendants to testify "will inevitably compel the defendant to testify, and will have substantially the same effect as if it did not go through the mockery of saying that he might testify if he pleased." ${ }^{462}$

Yet if the defendant did as he must and took the stand, he faced a second unpleasant alternative: Those defendants who had criminal records would be "torn to pieces by cross-examination." ${ }^{463}$ That is because the law of evidence permitted lawyers to impeach the testimony of opposing witnesses by showing they had been convicted of a crime. ${ }^{464}$ In the days when defendants could not testify, they rarely had to fear that their past wrongs would become evidence against them. But having gained the right to testify, they found themselves subject to the same rules of impeachment that confronted all other witnesses. ${ }^{455}$ Ames himself, sitting as a trial judge

457. 1866 Mass. Acts at 245 .

458. [Seth Ames], Testimony of Persons Accused of Crime, 1 AM. L. REV. 443, 444 (18661867); see also DAVID M. GOLD, THE SHAPING OF NINETEENTH-CENTURY LAW 188 n.22 (1990) (identifying Ames as the author of this work).

459. Ames, supra note 458 , at 445 .

460. Id. at 445; see also William A. Maury, Validity of Statutes Authorizing the Accused To Testify, 14 AM. L. REV. 753, 762-63 (1880) (arguing that even those defendant testimony laws that bar a negative inference from silence "force [the defendant] to take the stand to protect himself from the inference of guilt which is almost sure to be drawn against him if he fail to do so"). A century after Ames wrote, Kalven and Zeisel referred to "the common-sense inference of the defendant's guilt, if he chooses not to talk." HARRY KALVEN, JR. \& HANS ZEISEL, THE AMERICAN JURY 145 (1966).

461. Ames, supra note 458 , at 447.

462. Id. at 444 . Kalven and Zeisel reported on the basis of their 1950 s sample that $82 \%$ of defendants took the stand at trial. See KALVEN \& ZEISEL, supra note 460, at 33 n.1, 144.

463. Ames, supra note 458 , at 447.

464. See Act of May 22, 1852, ch. 312, § 60, 1852 Mass. Acts 235, 235 ("And the conviction of any crime may be shown to affect the credibility of any person testifying."); 3 JOHN HENRY WIGMORE, A TREATISE ON THE ANGLO-AMERICAN SYSTEM OF EVIDENCE IN TRIALS AT COMMON LAW \$ 980(1)(a), at 538 (3d ed. 1940).

465. The rule permitting impeachment by evidence of past conviction was more than a century old. See 3 WIGMORE, supra note 464, $\S 980$, at 539 (citing 17th-century cases). But because those convicted of any infamous crime were altogether disqualified from testifying, the impeachment rule probably did not come up often. See Commonwealth v. Gorham, 99 Mass. 420 , 421 (1868) (argument of counsel) ("The doctrine of the common law was, that conviction of an infamous crime, followed by judgment, rendered a witness incompetent."). A Massachusetts act 
shortly after Massachusetts enacted its defendant-testimony law, admitted evidence that a testifying defendant previously had pled guilty to forgery. ${ }^{466}$ Ruling on appeal in that case, the Supreme Judicial Court wrote that " [t]he defendant... offered himself as a witness, and the rules of evidence affecting the competency or credibility of witnesses were all applicable to him in that character." ${ }^{467}$

The law of evidence no longer lumps criminal defendants together with ordinary witnesses. Courts now recognize that a testifying defendant who is impeached with his past crimes suffers a risk that confronts no other witness: Juries may regard the defendant's past crimes as evidence not merely that he is a liar-the purpose for which they are admitted-but also that he is a thief (or rapist or murderer) and convict him on that basis. Most evidence codes therefore limit impeachment of defendants with past crimes, though they by no means forbid the practice. ${ }^{468}$ But those defendants who chose to testify in nineteenth-century Massachusetts enjoyed no such protection. In 1868 the Supreme Judicial Court reviewed a trial judge's ruling that admitted evidence of the defendant's past crimes "to affect his credibility as a witness, but for no other purpose." ${ }^{-69}$ The defendant's counsel complained on appeal "that it is a subtlety beyond the capacity of jurors" to confine such evidence to its impeachment value rather than "regarding it as affecting his character generally." $\$ 70$ To this the high court curtly replied:

By availing himself of the privilege [to testify, the defendant] assumed the character of a witness, and subjected himself to the liabilities incident to that position. The statute does not exempt him from cross-examination, and impeachment as a witness; and there is no reason why he should be exempt from it. ${ }^{471}$

of 1852 abolished the rule disqualifying felons and at the same time provided that all witnesses could be impeached with evidence of past crimes. See $\S 60,1852$ Mass. Acts at 235.

466. See Gorham, 99 Mass. at 420.

467. Id. at 421 (citing Commonwealth v. Bonner, 97 Mass. 587 (1867)).

468. See, e.g., FED. R. EVD. 609(a)(1) (allowing evidence of past crimes to impeach other witnesses as long as the probative value of the evidence is not substantially outweighed by the risk of unfair prejudice, but allowing such evidence against criminal defendants only if its probative value outweighs the risk of unfair prejudice). In Massachusetts, the governing statute does not itself distinguish between impeachment of defendants and other witnesses. See MAss. GEv. LAwS ANN. ch. 233, \& 21 (Law. Co-op. 1986). But the Supreme Judicial Cour has recognized that "[t]he admission of evidence of prior convictions presents the risk that the fact finder's attention may be diverted from the question of the defendant's guilt to the question of the defendant's bad character" and therefore has required trial judges to balance the impeachment value of the evidence against the "danger of unfair prejudice" before admitting evidence of past crimes against criminal defendants. Commonwealth v. Fano, 400 Mass. 296, 303 (1987).

469. Bonner, 97 Mass. at 588.

470. $I d$.

471. Id. at 589. 
In 1889 the Supreme Judicial Court even permitted the defendant in a liquor-selling case to be impeached with evidence of a past liquor-selling conviction despite a real risk that the jury would convict her simply because she had committed the same crime before. ${ }^{472}$

Ames did not venture to predict the consequences of a law that presented accomplished criminals with the options of being convicted on their silence or convicted on their testimony. And although others of Ames's day saw the dilemma that he saw, ${ }^{473}$ the task of explaining its full impact fell to a New York prosecutor of a later generation who wrote with the benefit of four decades' experience with these statutes. Arthur Train, son of Middlesex prosecutor Charles Russell Train, ${ }^{474}$ was serving as an assistant district attorney in Manhattan in 1906 when he wrote The Prisoner at the $\mathrm{Bar}^{475}$ the first of his series of chatty commentaries on the state of criminal justice. Train confirmed, first of all, the two horns of Ames's dilemma. On the one hand, those defendants who "do not testify ... will probably pay the usual penalty" : 476

Three jurors out of five will convict any man who is unwilling to offer an explanation of the charge against him. How they reconcile this with their oath it would be hard to understand, if they were accustomed to obey it literally in other respects. The writer has heard more than one talesman say, in discussing a verdict, "Of course we couldn't take it against him, but we knew he was guilty because he was afraid to testify." 477

472. See Commonwealth v. Sullivan, 150 Mass. 315, 317 (1889) ("The defendant having testified, the record of her conviction of a crime was admissible to affect her credibility."); $c f$. Fano, 400 Mass. at 303 (noting the particular danger of unfair prejudice to a criminal defendant "if a prior conviction is substantially similar to the crime being tried").

473. In 1869, only months after New York had given criminal defendants the right to testify. the New York Times wrote:

The moment they become witnesses [criminal defendants] subject themselves, like other witnesses, to the cross-examination of the District-Attomey, which may extend to their whole past career, and is sure to bring out facts that prejudice their case. It may be asked, then, why the guilty should avail themselves of the law and take the stand? ... The truth is, if they do not take the stand, a strong presumption of their guilt is inevitable in the minds of the jury; for although the law expressly declares that the failure on the part of the prisoner to avail himself of its privilege, shall not work any presumption against him, yet, as was very pointedly stated by Mayor Hall in discussing the law, "the proviso is like all other attempts to legislate against moral convictionsan abortion." Juries will draw an inference unfavorable to the man who refuses to take the stand and declare his innocence ... although the law declares they shall not.

The New Law, N.Y. Times, Sept. 13, 1869, at 2; see also Act of May 7. 1869, ch. 678, § 1. 1869 N.Y. Laws 1597, 1597.

474. See 14 National CYClOPEDIA OF AMERICAN BIOGRAPHY 427 (1910).

475. TRAIN, supra note 199.

476. Id. at 164 .

477. Id. at 161. Train cited the experience of one of his colleagues: "Out of three hundred defendants tried by the writer's associate, Mr. C. C. Nott, twenty-three failed to take the stand in 
On the other hand, those who do testify, if they have criminal pasts, "are more than likely to be convicted 'on their records" : $:^{478}$

The professional criminal usually has a "record" and he knows full well that in view of his past history, if there be any sort of a case against him, his own defence, however eloquent or ingenious, will go for nothing. An affirmative answer to the simple question, "Have you ever been convicted?" is, in three cases out of five, equivalent to a plea of guilty. ${ }^{479}$

In fact, Train wrote, even defendants who remained silent were likely to be convicted on their records: An experienced juror "discovers that the district attorney cannot prove the prison record ... of the defendant unless the latter subjects himself to cross-examination by taking the witness-stand, and hence is likely to suspect that any defendant who does not testify is an exconvict." 480 .

The consequence of the defendant's predicament is "that the jury in the ordinary run of criminal cases passes upon the guilt or innocence of very few professional criminals." ${ }^{481}$ Instead, a defendant with a criminal past, who therefore has the choice of being convicted on his silence or convicted on his record, "generally throws up his hands and stolidly takes his medicine"-and "dickers for the lowest plea he can get." 182 And "when the jury disband at the conclusion of the term with the thanks of the court, they have seen few professional criminals, save for a fleeting glance as one or two are led to the bar to admit their guilt." ${ }^{483}$ The upshot was that a law that purported to grant defendants a new right to testify at trial instead deprived those defendants who had criminal records of the right to any meaningful trial-and left them with little alternative but to seek the best plea bargain they could get.

What Ames anticipated and Train witnessed was not peculiar to their part of the country. By the turn of the century, every state but Georgia permitted defendants to testify. ${ }^{484}$ In California, which passed a defendanttestimony law in 1866 just ahead of Massachusetts, ${ }^{\text {tss }}$ Friedman and Percival saw an unexpected second dimension to the link between defendant-testimony laws and defendants' incentives to plead. They quote a

cases submitted to the jury. Of these twenty-one were convicted, one was acquitted, and as to one the jury disagreed." Id. at 163.

478. Id. at 164 .

479. Id. at 148 .

480. Id. at 161 .

481. Id. at 148 .

482. Id.

483. Id. at 169.

484. See Ferguson v. Georgia, 365 U.S. 570,577 \& n.6 (1961).

485. See supra note 455. 
judge at a 1910 sentencing hearing congratulating a defendant on his good sense in pleading guilty: "You can rest assured if you had gone on the witness stand and told some perjured tale about this affair, you would have received a heavier sentence." ${ }^{486}$ This rationalization brilliantly expands the versatility of defendant-testimony laws as a spur to plea bargaining. First, it grants those judges who pretend to shun plea bargaining of a crasser sort a noble basis for rewarding the defendant's plea. Second, it gives judges an appropriately principled reason to punish defendants for wasting the court's time with a trial: After all, the jury's guilty verdict normally conveys its judgment that the defendant, if she testified, lied ${ }^{487}$ And most importantly, the judge's reasoning creates an Ames-like dilemma not just for those defendants who have criminal histories that might be grounds for impeachment, but for all defendants. All defendants risked being convicted for their silence, and when tried before judges intent on punishing them for their perjury, all of them risked an aggravated penalty for speaking as well.

To the extent that defendant-testimony laws lowered defendants' perceived chances of winning at trial or heightened their fears of increased penalties should they select trial, choose to testify, and lose, these laws made defendants more willing to plea bargain - and perhaps made them more willing to plead guilty even without a promised concession in the hope that their plea would win the judge's favor. Of course, other developments also might have moved defendants to believe that their chances at trial were hopeless. Some scholars have argued that the rising efficiency of the police generated more evidence and tighter cases-a reasonable enough theory, but I have seen no suggestion by contemporaries that good police work was making it harder for defendants to win at trial. In any event, Train's report makes it clear that at least some defendants who might have chosen trial under the old regime declined trial under the new.

There is no reason to expect that this effect would be immediate. The dynamic that Train described turned on juror expectations: Because jurors expected defendants to testify, a defendant could not afford to sit quietly through his trial. Juror expectations presumably would not change overnight-and only after jurors had internalized the new order, in which

486. Proceedings upon Sentence at 5-6, People v. Schroeder, No. 4025 (Alameda Super. Ct. 1910), quoted in FRIEDMAN \& PERCIVAL, supra note 135, at 181.

487. See Proceedings upon Sentence, People v. Sullivan, No. 4837 (Alameda Super. Ct. 1910) (quoting a judge who justified a heavy sentence to the defendant by noting that "[y]ou were not only willing to commit the offense, you were willing to go upon the witness stand and state that which was not true"), cited in FRIEDMAN \& PERCIVAL, supra note 135, at 214; see also Heumann, supra note 146, at $526 \mathrm{n} .18$ (noting the same principle at work in modern-day Connecticut); The New Law, supra note 473 (relating the complaint of criminal defense lawyers that when their clients testify under New York's new defendant-testimony law, they often lic. "and then when they come to be sentenced the Court does not scruple to give them the extreme penalty of the law, and give as a reason for his severity that they have added to the crime with which they were charged that of perjury"). 
defendants could take the stand, would they become suspicious of those defendants who did not. So the result in Massachusetts might be just about what we would expect: The dramatic conversion to a plea-bargaining regime, shown in Figure 4, began just about a decade after defendants first began to take the witness stand.

That defendant-testimony laws proved to be of such convenient assistance to plea bargaining's cause was not, I think, a matter of design. These laws were the culmination of a long legal evolution-one that wiped out a whole series of old common-law rules that barred the testimony of certain classes of persons ${ }^{488}$-and not the brainchildren of nineteenthcentury prosecutors or judges intent on squeezing defendants into passing up their trial right. Even as bitter a critic of the new laws as Seth Ames failed to mention that the dilemma he set out with such pith would produce more pleas of guilty. There is no evidence in the early history of defendanttestimony laws that their backers promoted them either openly or otherwise as instruments of plea bargaining.

But neither do I think that the quick and durable success of laws that happened to encourage plea bargaining was pure good (or ill) fortune. We now have traced two of the nineteenth century's greatest innovations in criminal procedure-probation and defendant-testimony laws-to plea bargaining's doorstep. Of these, only probation took form in some measure as the work of a plea-bargaining regime, but both proved strong allies in the cause. What's more, they proved to be coordinated allies. Although defendant-testimony laws helped persuade all defendants to plead guilty, they worked best, for the reasons we have seen, against defendants with criminal pasts. And although few jurisdictions barred probation for defendants with criminal pasts, it quickly developed in Massachusetts and elsewhere that few but first offenders got probation, ${ }^{489}$ and some states made this practice law. ${ }^{490}$

488. See George Fisher, The Jury's Rise as Lie Detector, 107 YALE LJ. 575, 656-98 (1997).

489. John Augustus, Boston's pioneering unofficial probation officer, wrote in 1852, "I confined my efforts mainly to those who were indicted for their first offence...." AUGUSTUS. supra note 387, at 19. Boston's (and the nation's) first official probation officer. Edward $H$. Savage, wrote in his annual report for 1880 that 341 of 376 probation cases he had disposed of that year involved first offenders. See EDWARD H. SAVAGE, ANNUAL REPORT OF THE PROBATION OFFICER FOR SUFFOLK COUNTY, FOR THE YEAR 1880, at 1-2, 8 (Boston. Rockwell \& Churchill 1881) [hereinafter SAVAGE, ANNUAL REPORT]. Under the heading "First Offences," Savage wrote that "very few are probated who have once been in prison." Id. He urged courts to give "mature consideration" to their apparent belief " that there is little hope for a second comer." Id: see also EDWARD H. SAVAGE, POLICE RECORDS AND RECOLLECTIONS, OR BOSTON BY DAYLIGHT AND GASLIGHT FOR TWO HUNDRED AND FORTY YEARS at xiii (Patterson Smith 1971) (1873) [hereinafter SAVAGE, POLICE RECORDS AND RECOLLECTIONS] (noting that Savage served as Boston's first regular probation officer); BOSTON EVENING TRANSCRIPT, Jan. 15, 1880, at 1 (reporting that Savage's first annual report said that about $95 \%$ of his cases were first offenses). Eight years later, Savage wrote that "a large majority of the cases recommended are for first and minor offences." EDWARD H. SAVAGE, PROBATION WORK FOR THE COUNTY OF SUFFOLK: THE TENTH ANNUAL REPORT FOR THE CENTRAL PROBATION DISTRICT 16 (Boston. Rockwell \& 
I will wait until Part VII to explore the evolutionary principles that might explain the spread and staying power of institutions that so handily promoted plea bargaining's cause. For now it is enough to realize that, going into the last quarter of the nineteenth century, two of the three major courtroom actors had strong incentives to plea bargain. They lacked only the power. Prosecutors had lost the power to charge bargain once granted them by the peculiar penalty structure of the liquor laws. Their power to put defendants on probation by means of on-file plea bargains could not reasonably extend to the more serious crimes on the docket. And murder cases, in which prosecutors retained the power to charge bargain and used it extensively, made up only a tiny fraction of the docket. Criminal defendants, who had complete power to fulfill their end of any bargain by pleading guilty, had of course no power to ensure a reward for their pleas. The full development and final victory of plea bargaining as a systemic regime therefore awaited the judge's helping hand. The judge held most of the power to sentence, but until the last quarter of the nineteenth century, he had stayed mainly out of the plea-bargaining fray. For the interests of plea bargaining had not yet touched his own.

\section{JUDGES AND THE POWER TO SENTENCE}

In our journey through the first three-quarters of the nineteenth century, we have stumbled over no evidence that judges commonly lent their aid in plea bargaining. The great proportion of defendants who pled guilty at the beginning of the century do not seem to have done so in exchange for a reward promised by - or perhaps even expected from-the judge or anyone

Churchill 1889) [hereinafter SAVAGE, PROBATION WORK FOR THE COUNTY OF SuFfolk]. The probation officer for the state's central district reported that over seven years, 1129 of 1598 disposed probation cases involved first offenders. See id. at 22.

A generation later, a Chicago lawyer wrote, "It is assumed that a probation system is one which results in the establishment of the principle that a first offender... shall be relieved of punishment..." Albert Kocourek, An Unconsidered Element in the Probation of First Offenders, 6 J. CRIM. L. \& CRIMINOLOGY 9, 10 (1915-1916). Lynn M. Mather reports that in Los Angeles in the 1970s, when the offense was minor, the "lack of prior record indicated the likelihood that probation would be granted.” LYNN M. MATHER, PLEA BARGAINING OR TRIAL? 32 (1979).

490. When New York acted to permit suspended sentences (an elaboration of the probation procedure) in 1893, it limited the practice to persons not previously convicted of a felony. See Act of Apr. 4, 1893, ch. $279, \S 1,1893$ N.Y. Laws 559, 559. According to a 1905 rule, abandoned in 1918, convicted felons could never be granted probation. See Act of May 6, 1918, ch. 457, \$ I. 1918 N.Y. Laws 1339, 1339-40; Act of May 29, 1905, ch. 655, \$ 1, 1905 N.Y. Laws 1664, 1664: see also TIMASHEFF, supra note 387, at 19,54. Maryland's 1894 probation act limited the practice to first offenders found guilty of noncapital offenses. See Act of Apr. 6, 1894, ch. 402. \$1. 1894 Md. Stat. 583, 583-84. In 1926, the Massachusetts legislature declared that "no person convicted of a felony by a district court shall be placed on probation by said court . . . if it shall appear that he has been previously convicted of any felony." Act of Apr. 23, 1926, ch. 271. $\$ 1$. 1926 Mass. Acts $267,267$. 
else. Their sentences appear to have been no lighter than those of defendants who wagered trial and lost. Perhaps they pled guilty in the hopeless realization that without a lawyer, they had small chance of prevailing at trial. ${ }^{491}$ If so, then rising numbers of lawyers in the early decades of the century stanched this flow of unrewarded pleas. The result, as we saw in Figure $4,{ }^{492}$ was that through the middle third of the century, the rate of guilty pleas reached the lowest point in our period.

Though prosecutors suffered under the crushing caseloads of the 1840s and 1850 s, they could do little to lighten their loads, for their power to plea bargain had strict bounds. Working with what pockets of power they had, they devised two forms of plea bargaining and conducted each with little or no judicial assistance: In liquor and murder cases they took advantage of the law's peculiarly rigid penalty scheme and their initially unsupervised nol pros power to initiate charge-bargaining regimes. During the legislature's 1844 investigation into his bargaining practices, Asahel Huntington laid before the committee his sophisticated practice of multiple charging and selective nol prossing. That judges played no substantial role in this scheme must have been clear to the legislators, for when they set out to restrict such deals in the 1852 liquor prohibition act, they declared that "a nolle prosequi shall not be entered by the prosecuting officer [in liquor cases], except with the concurrence of the court." ${ }^{493}$ It seems legislators were right to think prosecutors were the problem, for in 1853, court records disclose no multiple charging in liquor cases and no more charge bargains. ${ }^{494}$ Judges apparently withheld their "concurrence" from charge bargaining in liquor cases.

Stripped of the unilateral power to charge bargain, prosecutors retreated to the second form of plea bargaining permitted by their limited powers: By promising to withhold a motion to sentence in exchange for the defendant's plea, they engaged in on-file plea bargaining in a broad range of cases. In liquor cases, the legislature again defeated the tactic simply by making judges partners in the prosecutors' power. By declaring that "[n]o [liquor] case... shall be laid on file... unless ... upon the certificate of the presiding magistrate or judge," ${ }^{495}$ the 1865 Act To Prevent Evasions largely ended on-file plea bargaining in liquor cases. For most of the latter half of the nineteenth century, therefore, the only forms of clear plea bargaining that appear more than occasionally on the records and dockets of Middlesex County are those in which the legislature left the prosecutor's unilateral

491. See supra notes $441-442,446$ and accompanying text.

492. See supra Figure 4; notes 435-440, 446-449 and accompanying text.

493. Act of May 22,1852, ch. 322, $\$ 13,1852$ Mass. Acts 257, 264 (cmphasis added).

494. See supra notes $173-178$ and accompanying text.

495. Act of May 12,1865, ch. 223, $\$ 1,1865$ Mass. Acts 617,617 (concerning the prevention of evasions of provisions of the general statutes regarding liquor cases): sec also supra notes 280283 and accompanying text. 
power to deal unmolested: charge bargains in murder cases and on-file plea bargains in non-liquor cases.

Not all plea bargains, of course, appear on the record books as clear plea bargains, in which the clerk disclosed the concession granted for the defendant's plea. There may have been many defendants who had quiet assurances of lighter sentences should they plead guilty and many others who had real, though unspoken, reasons to believe that their plea would reap a lenient reward from the judge. The long-depressed plea rates of the middle third of the century, however, suggest judges did not commonly dispense such rewards.

Beginning in the 1870 s, however, the rate of guilty pleas turned first mildly and then sharply upward. After a modest retreat in the 1890s, the rate turned upward again and in 1900 reached its highest point in our period, where it remained in 1910. It is hard to escape the conclusion that judges had begun to engage in sentence bargaining. We cannot attribute the enormous growth in guilty pleas to a change in the power or preferences of prosecutors. No new law either restored their power to charge bargain in liquor cases or created in other broad categories of crime the kind of rigid penalty scheme that first gave prosecutors that power in liquor and murder cases. In 1890, charge bargains still accounted for only four percent of all guilty pleas, and the twenty-seven charge bargains I saw in 1900 amounted to only six percent of all pleas. ${ }^{496}$

Nor did anything so drastically alter defendants' capacities or incentives that it could explain the huge rise in guilty pleas at century's end. As the proportion of defendants with counsel held fairly steady through the last four decades of the century, ${ }^{497}$ there is little reason to think that a growing proportion of defendants pled guilty out of sheer hopelessness. ${ }^{498}$ It

496. Moreover, only one of these 27 cases looked like an old liquor charge bargain in that the prosecutor's manipulation of the charges dictated the sentence. That was a murder case. in which the prosecutor reduced a charge of first-degree murder, which called for mandatory death, to second-degree murder, which called for mandatory life imprisonment, in exchange for the defendant's plea. See Commonwealth v. William H. Kelley, Middlesex Super. Ct. R. Book 368. No. 26 (1900). The legislature had transferred jurisdiction to try murder cases from the Supreme Judicial Court to the superior court in 1891. See Act of June 6, 1891, ch. 379, $\$ 1.1891$ Mass. Acts 966, 966; see also DAVIS, supra note 7, at 254 (reviewing this jurisdictional history).

In almost all of the other cases, the judge's sentence was well below the maximum of the reduced charge, and so the defendant arguably won only the collateral rewards that might have come with a lesser crime of conviction. For some defendants, these rewards might have been substantial, but the very small total number of charge bargains suggests that for most defendants. they held little allure.

497. See supra note 436 and accompanying text.

498. If anything, those defendants unfortunate enough to come to court without lawyers had reason to be more hopeful than in years past. In 1900, of 34 defendants with counsel who went to trial, 20 won acquittals or hung juries-a success rate of $59 \%$. Fifteen of the 39 unrepresented defendants who risked trial also won acquittals or hung juries-or $38 \%$. Having counsel was still a benefit, but going to trial alone proved less hopeless than it had at the middle of the century. See supra note 442 and accompanying text. I cannot explain why unrepresented defendants fared better at trial in later years. 
is likely that a fair number of guilty pleas grew out of the 1866 defendanttestimony law, which diminished the power of defendants with criminal pasts to take a winning case to trial and might have prompted them to plead guilty without a guaranteed concession. But the booming increase in guilty pleas during the last quarter of the century must have been due to more. By 1900 the proportion of adjudicated cases resolved by plea had grown simply too large - eighty-seven percent ${ }^{399}$ - for us to believe that so many defendants pled guilty without a real and rather certain reward.

In fact, sentencing patterns suggest that judges rewarded defendants for their pleas. Table 5 reports the sentencing data for four of the most frequently prosecuted crimes in the last two decades of the century. Only in theft cases was the benefit to those who pled guilty less than dramatic. In breaking-and-entering cases, defendants who went to trial and lost spent on average about twice as long in prison as those who pled guilty. In assaultand-battery cases, those who lost after trial were almost three times as likely to go to prison as those who pled guilty. And in liquor cases, not only were those who lost after trial more than three times as likely to go to prison, but they also paid far more in fines and costs. I have excluded from these calculations all cases that were placed on file after the defendant's plea of guilty because I want to isolate the judge's role in sentencing, and it is unclear in these decades how the judge and prosecutor divided the power to place cases on file. ${ }^{500}$ As the number of on-file plea bargains in these years was quite large, ${ }^{501}$ had I included them, the "sentencing" advantage to defendants who pled guilty would have appeared even starker.

499. Figure 4 understates the proportion of defendants who pled guilty at century's end because I excluded from that diagram liquor prosecutions and filed cases. I did so to avoid the distorting impact of the prosecutors' power to bargain in those cases, especially in earlier decades. as well as the distorting impact of changes in the liquor laws and in the rates of liquor prosecutions. See supra note 424 and accompanying text. By the last third of the century, of course, prosecutors had lost their power to charge bargain in liquor cases, and by the last two decades of the century, judges perhaps had assumed more of the power to place cases on filc. See supra notes 367-376 and accompanying text. When I retum the excluded cases to the pool. the proportion of adjudicated cases settled by plea in 1900 rises to $87 \%$.

500. See supra notes 367-376 and accompanying text.

501. In 1880, for example, on-file plea bargains made up $34 \%$ of all pleas. By 1900 . that figure had climbed to 48\%. See Middlesex Super. Ct. R. Books (1880, 1900); Middlesex Super. Ct. Docket Books $(1880,1900)$. 
TABLE 5. SENTENCE ACCORDING TO MODE OF CONVICTION: MIDDLESEX SUPERIOR COURT, $1880-1900$

\begin{tabular}{|l|c|c|c|c|c|c|c|c|}
\hline & \multicolumn{2}{|c|}{$\begin{array}{c}\text { Breaking and } \\
\text { Entering }\end{array}$} & \multicolumn{2}{c|}{$\begin{array}{c}\text { Simple } \\
\text { Theft }\end{array}$} & \multicolumn{2}{c|}{$\begin{array}{c}\text { Assault and } \\
\text { Battery }\end{array}$} & \multicolumn{2}{c|}{$\begin{array}{c}\text { Liquor } \\
\text { Crimes }^{503}\end{array}$} \\
\hline & Plea & Trial & Plea & Trial & Plea & Trial & Plea & Trial \\
\hline Number & 66 & 20 & 38 & 10 & 38 & 13 & 84 & 30 \\
\hline $\begin{array}{l}\text { Avg. Value } \\
\text { of Stolen } \\
\text { Goods }\end{array}$ & $\$ 39$ & $\$ 42$ & $\$ 78$ & $\$ 346$ & -- & -- & -- & -- \\
\hline$\%$ Prison & 100 & 100 & 89 & 100 & 21 & 62 & 15 & 53 \\
\hline $\begin{array}{l}\text { Avg. Term } \\
\text { (months) }\end{array}$ & 18.7 & 38.5 & 10.7 & 12.8 & 5.8 & 5.5 & 3.6 & 3.4 \\
\hline \% Fine & 0 & 0 & 11 & 0 & 79 & 46 & 99 & 100 \\
\hline Avg. Fine & -- & -- & $\$ 28$ & -- & $\$ 20$ & $\$ 21$ & $\$ 67$ & $\$ 106$ \\
\hline Avg. Costs & -- & -- & -- & -- & $\$ 17$ & $\$ 21$ & $\$ 22$ & $\$ 50$ \\
\hline
\end{tabular}

Sources: Middlesex Super. Ct. R. Books (Oct. 1880, June 1885, Feb. 1890, Oct. 1896. 1900).

These figures reflect more, I believe, than the impulsive generosity of judges who were gratified to see defendants admit their guilt. Rather, they are strong evidence that by the last quarter of the century, judges had become full partners in a thriving practice of sentence bargaining. I now face the question of motives: Why would a judiciary that once shunned taking part in prosecutorial plea bargaining later, in the last quarter of the century, take up plea bargaining with enthusiasm? In Part II, when we encountered judges' early resistance to plea bargaining, I suggested that the practice faced at least three obstacles to judicial acceptance: Judges lacked

502. I have excluded breaking and entering a residence because it is substantially more serious than other breaking-and-entering crimes.

503. For purposes of this table, liquor crimes include keeping liquor with intent to sell, making unlicensed sales, and maintaining a liquor nuisance. In this time frame, the first two of these were punishable by a fine of between $\$ 50$ and $\$ 500$ or imprisonment of between one and six months or both. See Act of Apr. 5, 1875, ch. 99, \$§ 1, 13, 1875 Mass. Acts 664, 664, 668 (regulating the sale of intoxicating liquors). Maintaining a liquor nuisance was punishable by a fine of between $\$ 50$ and $\$ 100$ and imprisonment of between three and twelve months. See MASS. REV. LAWS ch. 101, § 7 (1902).

504. "Avg. Term" refers to the average term of confinement of those defendants sentenced to serve time. I have excluded from this calculation those defendants sentenced to an indefinite time at the Massachusetts Reformatory or a juvenile facility. See infra notes 731, 733-735 and accompanying text (discussing the Massachusetts Reformatory). When the judge specified a minimum and maximum term in state prison, I have calculated a sentence midway between the minimum and maximum.

505. Costs were very rarely assessed when the defendant served time. No costs were assessed in 1896 or 1900. See Middlesex Super. Ct. R. Books (1896, 1900). 
the incentives to bargain that prosecutors found in their crushing workloads and in their taste for effortless convictions; judges objected on principle to the idea of passing sentence without full information about the defendant's crime and background; and proud judges took offense at having to share sentencing power with prosecutors. Yet by century's end, a form of plea bargaining that seemed to demand judicial complicity was thriving. Some things must have changed.

I will argue in the next three sections that some things did change-and changed in a way that gave judges a real incentive to plea bargain, weakened their principled resistance to plea bargaining, and protected their pride from prosecutorial invasion of their sentencing power. The new incentive came from an exploding civil caseload, brought about by a revolution in transportation and industry and a resulting wave of tort actions of unprecedented number and complexity. Judges' principled objections gave way as newly commissioned probation officers investigated defendants' crimes and backgrounds and gave judges enough information to make reasoned sentencing decisions without a trial or sentencing hearing-and as new parole boards with the power to tailor sentences let judges feel that they did not need to get sentences exactly right anyway. And judicial pride found refuge in the development of sentencing mechanisms that let prosecutors make promises in the course of plea bargaining without taking sentencing power (or at least without taking it overtly) from judicial hands.

\section{A. Incentives: The Judges' Caseload Pressure}

On October 14, 1885, a Salem lawyer named Charles Thompson made a note in his diary: "This P.M. news came that I am appointed or nominated to judgeship of Superior $C t$. Several called to congratulate me." ${ }^{506}$ Eight days later, with the anomalous expedition of a slower age. Thompson could write that he had been "to Boston \& was qualified by Governor Geo D Robinson as Associate Justice of the Superior Court." $\$ 07$ Four days after that, our fifty-eight-year-old judicial novice was on the road: "Went to Pittsfield \& held Court for a fortnight." ${ }^{003}$ From Pittsfield, Thompson went to Greenfield, ${ }^{509}$ and from Greenfield, apparently, to Boston, where he held court until the night before Christmas. ${ }^{\text {sio }}$ For the next two years before his

506. 11 Diaries of Charles Thompson, supra note 189 (Oct. 14. 1885).

507. 13 id. (Oct. 22, 1885). Because Thompson kept separate diaries in his two offices, different volumes sometimes cover the same dates.

508. 13 id. (Oct. 26, 1885).

509. See 13 id. (Nov. 9, 1885).

510. After writing in an entry dated November 9 that he " [w]ent to Greenfield [and] held Court for a fortnight," Thompson made no further note of his itinerary until this entry - * Monday December 1885 Went to Greenfield" - which he followed with this vague comment: "Held 
diary came to a close, Thompson set down in staccato half-sentences his frenetic zigzags across the state, ${ }^{511}$ now and then stopping to punctuate, "Have been very busy" ${ }^{512}$ _ " [v]ery busy indeed" ${ }^{513}$ _." a number of cases not disposed of." 514

Knowing only this much, we could not say that Thompson had a harder time of it than his predecessors on the Court of Common Pleas. They too rode circuit, and although Thompson occasionally resorted to horseback, ${ }^{315}$ he at least normally had the option of the train. Moreover, there is plenty of evidence that judges in earlier times sometimes left for their next sitting before completing the calendar at the last. ${ }^{516}$ Nor can I argue that the evermounting criminal caseload of the last quarter of the century, when judges appear to have gone over to plea bargaining's cause, weighed more heavily upon them than before. Table 6 shows that through the last half of the century, the number of criminal cases per judge in Middlesex County never again got so bad as in 1849. It is true that as the district attorney began to draw a full-time salary and then to take on assistants, ${ }^{517}$ his office was able to bring a higher proportion of all cases before the court for its attention. But even when $I$ exclude all those cases that the district attorney presumably handled on his own or that took up little of the court's time (those ending in complete nol prosses, whether or not upon payment of costs, those placed on file without a guilty finding, and those in which the defendant failed to appear), the middle of the century remains the worst period I have studied in terms of criminal cases per judge.

Court ... Wednesday Night Dec. 9." Thompson then became more specific, noting that he "went to Boston and held court till Thursday night 24, 1885." 13 id. (undated entries). He spent the Christmas week at home. See 13 id.

511. See 13 id. (undated entry following Jan. 5, 1886) (noting that he sat court in Boston and Barnstable, then in Boston again); 13 id. (May 13, 1886) (noting that he sat in Worcester); 13 id. (June 30, 1886) (noting that he sat in East Cambridge); 13 id. (Dec. 24, 1886) (noting that he sat in Bristol, Lowell, East Cambridge, Boston, Plymouth, Dukes County, and Nantucket); 13 id. (Oct. 4, 1887) (noting that he sat in Springfield and Boston, then in Springfield again, and then in Boston); 13 id. (Nov. 12, 1887) (noting that he sat in Pittsfield).

512. 13 id. (undated entry following Jan. 5,1886 ).

513. $13 \mathrm{id}$.

514. 13 id.

515. See 13 id. (Oct. 4, 1887) ("Rode with horse [from Springfield] to Beverly.").

516. See Court of Common Pleas, supra note 201 ("No civil action has been tried [at the present sitting of the Court of Common Pleas], and none will be. The number of new entries is 436, of old about 900."); Criminal Cases Disposed of at the Late Session of C.C.P.. LOWELL COURIER, July 8,1841 , at 2 (explaining that "[m]uch business remained undisposed of, but Chicf Justice Williams . . . being obliged to hold the Term in Boston ... and the other members of the Court having engagements in other parts of the Commonwealth," the court was forced to adjoum); To Our Friend of the Concord Gazette We Send Greeting, LOWELL COURIER, Feb. 20. 1836, at 2 (referring to "the present crowded and overflowing state of the dockets of the C.C.P.").

517. See supra notes 132-145, 195-197 and accompanying text. 
TABLE 6. CRIMINAL CASES PER JUDGE:

MIDDLESEX COURT OF COMMON PLEAS AND SUPERIOR COURT ${ }^{318}$

\begin{tabular}{|c|c|c|c|c|c|}
\hline Year & $\begin{array}{c}\text { Total } \\
\text { Cases }\end{array}$ & $\begin{array}{c}\text { Number of } \\
\text { Judges }\end{array}$ & $\begin{array}{c}\text { Number of } \\
\text { Cases per } \\
\text { Judge }\end{array}$ & $\begin{array}{c}\text { Number of } \\
\text { Cases } \\
\text { Brought } \\
\text { Before a } \\
\text { Judge }\end{array}$ & $\begin{array}{c}\text { Number } \\
\text { per Judge }\end{array}$ \\
\hline 1824 & 48 & 4 & 12 & 39 & 10 \\
\hline 1829 & 41 & 4 & 10 & 27 & 7 \\
\hline 1834 & 95 & 4 & 24 & 65 & 16 \\
\hline 1839 & 42 & 4 & 11 & 36 & 9 \\
\hline $1843-1844^{*}$ & 112 & 5 & 22 & 93 & 19 \\
\hline 1849 & 443 & 6 & 74 & 271 & 45 \\
\hline 1853 & 482 & 7 & 69 & 319 & 46 \\
\hline 1859 & 415 & 10 & 42 & 257 & 26 \\
\hline $1864^{* *}$ & 292 & 10 & 29 & 159 & 16 \\
\hline $1870^{* *}$ & 449 & 10 & 45 & 309 & 31 \\
\hline $1880^{* *}$ & 486 & 11 & 44 & 330 & 30 \\
\hline 1900 & 602 & 18 & 33 & 546 & 30 \\
\hline
\end{tabular}

* Average per year

** Calculated from totals for one or two of the three annual sessions (see Appendix A)

Sources: Middlesex Ct. C.P. R. Books; Middlesex Ct. C.P. Docket Books; Middlesex

Super. Ct. R. Books; Middlesex Super. Ct. Docket Books.

Of course, cases per judge would be a poor measure of judicial caseload pressure if the burden of each case had been expanding over time. John Langbein has argued that the growing complexity of the law of evidence and "the lawyerization of the trial ... made jury trial so complicated and time-consuming that they rendered it unworkable as the routine dispositive procedure" and forced the system to turn instead to plea bargaining. ${ }^{519}$ The argument has enormous commonsense appeal. And in fact, my evidence suggests that increasing trial length may have played a part in the surge of plea bargaining in murder cases in the 1890s. But this evidence is uncertain, and there is little or no evidence of a broader connection between trial

518. See Act of Apr. 5, 1859, ch. 196, $\$ 7,1859$ Mass. Acts 339, 341 (setting the number of superior court judges at nine); DAVIS, supra note 7, at 243-44 (providing the number of judges through 1859); DIMOND, supra note 190, at 75, 77, 93, 97 (providing the number of judges from 1859 through 1900). Middlesex was one of 14 counties in the state. To get a real idea of how many cases each judge handled per year, one would have to repeat this analysis in each of the others. As Middlesex is large and diverse, there is no reason to think that its pattems of change were unlike those in Massachusetts as a whole.

519. John H. Langbein, Torture and Plea Bargaining, 46 U. CHI. L. REV. 3, 11 (1978). 
length and plea bargaining that can help explain plea bargaining's early rise.

We should begin in the upper tier, as the records of Supreme Judicial Court business give us a somewhat surer footing for conclusions. The annual reports of the attorney general, which commenced in 1832 and continued with occasional interruptions throughout the century, often noted the days consumed by trials before the high court. ${ }^{520}$ Table 7 reports the average length of murder trials during the last two-thirds of the century. ${ }^{521}$ Two striking facts emerge from this table, one opposing Langbein's thesis, one apparently supporting it. The first is the absence of any substantial increase in trial length between the 1830s, the last decade in which the records reveal no charge bargaining, and the 1860s, when almost half of all adjudicated murder cases ended in charge bargains. In fact, in the 1860s, the average trial length fell to its lowest point in our period. Then, as the length of trials rose slightly in the next two decades, the proportion of charge bargains fell.

TABle 7. Average LENGTH OF MASSACHUSETTS MURder TRIALS ${ }^{522}$

\begin{tabular}{|c|c|c|c|c|}
\hline Year & $\begin{array}{c}\text { Number of } \\
\text { Trials }\end{array}$ & $\begin{array}{c}\text { Number of } \\
\text { Trials with } \\
\text { Recorded } \\
\text { Lengths }\end{array}$ & $\begin{array}{c}\text { Average } \\
\text { Length of } \\
\text { Trials (Days) }\end{array}$ & $\begin{array}{c}\% \text { of Trials } \\
\text { Ending in } \\
\text { Charge } \\
\text { Bargains }\end{array}$ \\
\hline $1832-1839$ & 45 & 15 & 3.2 & 0 \\
\hline $1840-1849$ & 41 & 1 & 4.0 & 10 \\
\hline $1850-1859$ & 42 & 11 & 3.5 & 17 \\
\hline $1860-1869$ & 53 & 28 & 3.0 & 47 \\
\hline $1870-1879$ & 77 & 32 & 3.8 & 43 \\
\hline $1880-1889$ & 51 & 23 & 4.1 & 35 \\
\hline $1890-1899$ & 67 & 16 & 6.6 & 61 \\
\hline
\end{tabular}

Source: Annual Reports of the Attorney General.

520. The attorney general never recorded trial time with any precision. Most often, he noted the trial as a span-for example, "December 1-9" for an 1868 murder case. See Commonwcalth v. Samuel M. Andrews, listed in Report of the Attorney General for the Year Ending December 31, 1868, PUB. DoC. No. 16, at 17 (Mass. 1869). In such cases. I have assumed that the trial consumed both the beginning and ending day and every day in between. As I expect-but do not know-that courts were closed on Sundays, and as I have not determined which dates were Sundays, I have simply excluded one day in seven whenever the time span noted exceeded six days. Hence, I have assumed that the Andrews case, quoted above, consumed eight days.

521. I have limited myself to murder trials, rather than considering all capital trials, because murder cases may have taken more or less time to try than cases involving other capital offenses-and because, after mid-century, murder was virtually the only capital offense.

522. For my method of calculating the length of trials, see supra note 520. For an explanation of the incomplete records of the 1840s and 1850s, see supra notes $97,99$. 
On the other hand, Langbein's thesis finds support in the data from the $1890 \mathrm{~s}$, when both trial length and the proportion of charge bargains increased dramatically. But a complicating factor clouds this scene. By an Act of June 6, 1891, the legislature transferred jurisdiction over murder trials from the Supreme Judicial Court to the superior courts. ${ }^{523}$ As we saw in Figure 4, the overall rate of guilty pleas in Middlesex Superior Court turned up sharply during the last quarter of the century. If we exclude onfile plea bargains, which substantially increased the guilty-plea rate but never took place in murder cases, sixty-one percent of adjudicated nonliquor cases in superior court ended in guilty pleas in 1890 and seventy-nine percent in 1900. Given the dynamic of powers and interests that prevailed in the superior court and that I believe gave rise to the habit and culture of plea bargaining in that court, it would not be surprising to find that once this court adopted custody of murder cases, the rate of plea bargains would creep toward the overall average. A charge-bargaining rate of sixty-one percent in murder cases during this decade therefore might be just about what we would expect. And we might expect charge bargains to increase this rate even absent any increase in the length of murder trials.

If we look now only at the work of the superior court and court of common pleas, it is hard to discern any broad support for the thesis that increasing trial length led to the rise of plea bargaining. It is true that one prosecutor complained in the 1840 s that "[t]he labor of the trials is increased by the increased attendance of very eminent counsel in the defences." 524 But it is also true that court records reveal no clear trend toward substantially longer trials in the last quarter of the nineteenth century, when the guilty-plea rate in the courts of the middle tier grew tremendously. Perhaps that is because the proportion of defendants with counsel-the particular concern of the prosecutor just quoted-stayed fairly steady over the same time span. ${ }^{525}$

The Middlesex court clerk did not record the length of individual trials in the nineteenth century. Table 8 reports the number of days consumed by each criminal session of the middle-tier courts in Middlesex County and the number of cases tried per day. ${ }^{526}$ Because the Middlesex Court of Common Pleas did not begin to hold separate criminal and civil sessions until June 1839 , I have no earlier data. The low figures for trials per day in the earliest years (indicating long trials) probably mean that there were certain "fixed costs" at each session of the court-routine business that consumed court

523. See Act of June 6, 1891, ch. $379, \S 1,1891$ Mass. Acts $966,966$.

524. S. Doc. No. 68, at 7 (Mass. 1844) (petition of Samuel D. Parker).

525. See supra note 436 and accompanying text.

526. As the table makes clear, I have measured the number of "judge-days" - that is, if two or more judges were presiding in separate courtrooms for a span of days. I have multiplied the number of judges by the number of days. 
time but is not reflected in the number of cases disposed - so that when the sessions of the court were short, as they were early on, they appear to have been less efficient. And just as trials were probably faster than they appear in the earliest years, they were probably faster than they appear in the later years as well. In the later years, most sessions of the court had to process a good number of cases that did not go to trial-after all, the vast majority of cases ended in guilty pleas-but those cases still absorbed some of the court's time. $^{527}$

There is little here to suggest a sharp rise in trial length at the close of the century. The pace of trials in 1900 , when the rate of guilty pleas reached its end-of-century high, just about equaled the pace in 1849, when the guilty-plea rate reached almost its lowest point. ${ }^{528}$ In fact the best indication of a trend toward longer trials emerged after the turn of the twentieth century. The relatively slow trials of 1910 perhaps foreshadowed the longer trials of our day, but they cannot explain the plea-bargaining boom that marked the last decades of the nineteenth century. By 1900, the rate of guilty pleas had reached a plateau, where it remained essentially unchanged in $1910 .{ }^{529}$

527. In this respect, the table slightly understates the efficiency of the later years. Because of the district attorney's workload, he nol prossed or simply placed on file (without a plea) a higher proportion of cases in the middle of the century than toward the end, when he became a full-time official and took on assistants. The bench therefore had to deal with a greater proportion of the total cases coming into the court as the last half of the century wore on.

528. Friedman and Percival report an average length of trial in Alameda County of 1.5 days in 1880-1889. See FRIEDMAN \& PERCIVAL, supra note 135, at 185. Trials in Middlesex were a good deal shorter. In 1890, the Middlesex Superior Court heard 1.7 trials per judge-daysuggesting a trial length of about three-fifths of a day, minus enough time to make room for cases not resolved by trial. Except in murder cases, see supra Table 7 and accompanying text, I did not see a substantial increase in trial length at century's end. Friedman and Percival, in contrast, report an average trial length of 2.6 days in 1890-1899. See FRIEDMAN \& PERCIVAL, supra note 135, at 185.

Probably the most important reason for the immoderate-or at least unmodern-quickness of these 19th-century trials was that the same two juries sat throughout each session of the court with only slightly shifting memberships to suit the needs of each trial. The prosecutor had no right to make peremptory challenges in Massachusetts until 1862, further shortening the time taken in jury selection. See Act of Mar. 22, 1862, ch. 84, $\$ 1,1862$ Mass. Acts 64, 64. The practice of keeping the same jury from case to case helps to explain the very fast trial rates that John Langbein observed in late-17th-century and 18th-century London and that Friedman and Percival saw in Leon County, Florida, in the 1890s. See FRIEDMAN \& PERCIVAL, supra note 135, at 194 \& n.97 (reporting that Leon County trials "took, on the average, half an hour at most"); Langbein, supra note 425 , at 262 (reporting an average trial rate at the Old Bailey of between 12 and 20 felony cases a day well into the 18 th century).

529. I am not able to draw a perfect comparison between case dispositions in 1900 and those in 1910 because I could find only the record books and not the docket books for 1910 . Without the docket books, it is impossible to know how many of the filed cases, which appear simply as long lists of names in the record books, involved guilty pleas. But the record books for the two years suggest a remarkably similar pattern of case disposition. In 1900, the record book discloses 313 adjudicated non-filed cases, of which 240 - or $77 \%$-were resolved by plea. In 1910, the record book lists 288 adjudicated non-filed cases, of which 222 - or $77 \%$-were resolved by plea. 
TABLE 8. TRIALS PER DAY AND OTHER CASES PER DAY: MIDDLESEX COURT OF COMMON PLEAS AND SUPERIOR COURT

\begin{tabular}{|c|c|c|c|c|c|}
\hline Year & $\begin{array}{c}\text { Judge- } \\
\text { Days }\end{array}$ & $\begin{array}{c}\text { Trials } \\
\text { Trials per } \\
\text { Judge- } \\
\text { Day }\end{array}$ & Other Cases & $\begin{array}{c}\text { Other } \\
\text { Cases per } \\
\text { Judge- } \\
\text { Day }\end{array}$ \\
\hline $1839^{*}$ & 17 & 12 & 0.7 & 14 & 0.8 \\
\hline $1843-1844^{* *}$ & 117 & 94 & 0.8 & 130 & 1.1 \\
\hline 1849 & 79 & 131 & 1.7 & 312 & 3.9 \\
\hline 1853 & 54 & 93 & 1.7 & 389 & 7.2 \\
\hline 1859 & 78 & 130 & 1.7 & 285 & 3.7 \\
\hline $1864^{*}$ & 34 & 38 & 1.1 & 187 & 5.5 \\
\hline $1870^{*}$ & 33 & 62 & 1.9 & 121 & 3.7 \\
\hline $1880^{*}$ & 19 & 21 & 1.1 & 119 & 6.3 \\
\hline $1885^{*}$ & 26 & 24 & 0.9 & not measured & - \\
\hline $1890^{*}$ & 34 & 58 & 1.7 & not measured & -- \\
\hline $1896^{*}$ & 29 & 60 & 2.1 & not measured & -- \\
\hline 1900 & 44 & 70 & 1.6 & 532 & 12.1 \\
\hline 1910 & 111 & 66 & 0.6 & not measured & -- \\
\hline
\end{tabular}

* Totals for one or two of the three annual sessions (see Appendix A)

** Two-year totals

Sources: Middlesex Ct. C.P. R. Books; Middlesex CL. C.P. Docket Books; Middlesex Super. Ct. R. Books; Middlesex Super. C. Docket Books.

At bottom, I do not believe that criminal caseload pressure was the moving force behind the late-century judicial conversion to plea bargaining. ${ }^{530}$ To that extent I agree with Vogel and Ferdinand and others who have sought to debunk the long-accepted wisdom that rising caseload pressure brought on plea bargaining. ${ }^{531}$ But the received wisdom turns out

530. But Langbein's thesis might very well help to explain the continued advance of plea bargaining in the 20th century. See Alschuler, supra note 2, at 38 (citing studies showing that the length of the average felony trial grew from 3.5 days in 1964 to 7.2 days in 1968 in Los Angeles. and from 1.9 days in 1950 to 2.8 days in 1965 in the District of Columbia); Langbein, supra note 519, at 9 \& n.11 (reporting modem American plea-bargaining rates of up $1099 \%$ ).

531. For studies adhering to the accepted wisdom, see Heumann, supra note 146, at 516-17. For studies seeking to debunk it, see, for example, Heumann, supra note 146; and McConville \& Mirsky, supra note 243, at 463-64, who argue that New York City courts "absorb[ed]" a fivefold increase in criminal caseload between 1839 and 1865 , when the rate of guilty pleas was rising. Heumann's is the most sustained attack on the theory that caseload pressure prompted the rise of plea bargaining, but his analysis is not entirely convincing. He compares trial rates in low-volume and high-volume superior courts in Connecticut and finds that "trial rates between them varied minimally, and indeed often the low volume courts tried proportionately fewer cases." Heumann. supra note 146, at 521-22. Heumann admits that this mode of analysis is "rough" because, without knowing the number of prosecutors and judges in each court. "we cannot be sure that 
FIGURE 6. LENGTH OF CRIMINAL AND CIVIL SESSIONS: MidDLESEX COURT OF COMMON PLEAS AND SUPERIOR COURT

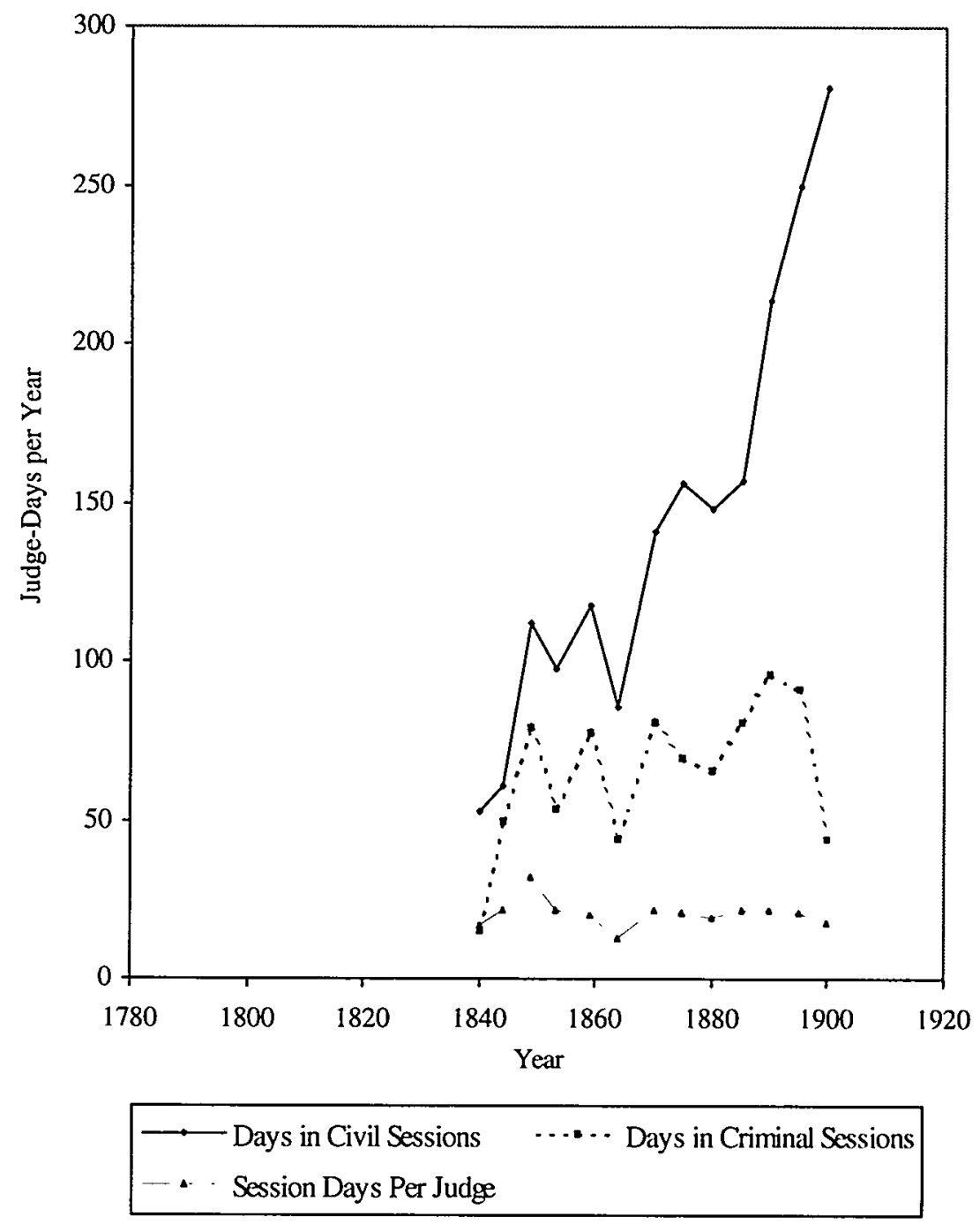

to be largely right-it simply focused on the wrong side of the courthouse. The crucial caseload pressure came not from criminal courtrooms but from their civil counterparts, a factor that all studies of this era have left out. ${ }^{332}$

volume reflects pressure." Id. at 520-21. Moreover, Heumann does not say whether the judges of the Connecticut Superior Court rode circuit over the period of his study or were otherwise shifted from one court to another when the first court's business was done. If so, then we would expect to find little variation in caseload pressure between those courts with many cases and those with few, and hence not much variation in the rates of trials.

532. See, e.g., FRIEDMAN \& PERCIVAL, supra note 135, at 42-43, 48 (failing to mention the civil caseload when arguing that the Alameda "Superior Court's workload was 
Figure 6 depicts judicial workload in its most irreducible form: the number of judge-workdays consumed each year by the criminal and civil business of the middle-tier courts. ${ }^{533}$ The lowest line, representing the total number of workdays per judge, shows that after the caseload depression of the Civil War had offset the highs of the late 1840s, judges were able to limit the share of their time devoted to Middlesex County business ${ }^{534}$ to about twenty days per judge per year throughout the last several decades of the century. The widening gap between the steeply rising line representing the civil workload and the jaggedly steady line representing the criminal workload makes it clear that judges maintained their overall workload only by devoting a smaller and smaller proportion of their time to criminal business. The greatly increasing efficiency of the judicial workday on the criminal side-rising from 3.3 cases per day in 1859 to 12.4 cases per day in $1900^{535}$-therefore served not to increase judges' leisure, but to increase the attention they paid to their civil caseloads.

The civil caseload phenomenon pictured in Figure 6 was neither a passing phase nor a Middlesex peculiarity. ${ }^{536}$ It represents instead one of the

not... oppressive," although a majority of the couri's judges devoted themselves to the civil caseload); Alschuler, supra note 2, at 34 (addressing the caseload problem only in terms of case pressure on the U.S. attomey's office); Heumann, supra note 146, at 523 n.10 (noting that the data would not permit analysis of the impact of civil caseload).

533. Because the court did not begin to hold separate criminal and civil sessions until partway through 1839, I have begun recording the time devoted to each session in 1840. Although the court of common pleas underwent a substantial reorganization in 1821. see Act of Feb. 14, 1821 , ch. $79, \S 1,8$ Mass. Laws 545, 545-46 (establishing a cour of common pleas). the fundamental operations of the cour did not change again throughout our period. At least since 1821, each judge of the court of common pleas and the superior coun could preside alone over sessions of the court. See id. Although the record and docket books are not absolutely clear on this point, I believe that judges always or almost always sat alone. In 1891, when the legislature transferred trial jurisdiction in capital cases to the superior court from the cour of common pleas, it required three judges to preside at such trials, see Act of June 6, 1891. ch. 379, 2,1891 Mass. Acts 966, 966, but then reduced the figure to two in 1894, see Act of Apr. 5. 1894, ch. 204, 1894 Mass. Acts 186, 186. There were, however, no murder trials in Middlesex County in 1896 or 1900, the two years that I studied after these law changes. so I did not need to figure this change into my calculations. Occasionally, two or more judges presided in different courtrooms at the same time, each of them sitting alone. When calculating the number of judge-days for Figure 6as well as for Table 8-I multiplied the number of judges sitting by the number of days. See supra note 526.

534. To figure the judges' total annual workload. we would have to repeat this analysis in each of the state's other 13 counties. If the business of Middlesex Counly was proportional to its population, then it accounted for about 18\% of Massachusetus coun work in this cra. See A COMPENDIUM OF THE NINTH CENSUS, supra note 3 , at 56; 1 COMPENDIUM OF THE TENTH CEnsus 34 (Washington, D.C., Government Printing Office 1883).

535. For these figures, I have divided the number of cases brought before the judges for resolution ( 257 in 1859,546 in 1900) by the number of judge-days in criminal sessions (78 in 1859,44 in 1900). The former figures exclude from the total caseload those cases disposed of by complete nol prosses, by being placed on file without a guilty plea, or because the defendant defaulted. See supra notes 295-296, 518 and accompanying iext.

536. See DIMOND, supra note 190, at 93, 96 (citing legislative reports showing a doubling of civil cases entered on the superior court docket statewide between 1880 and 1900 and continued increases afterward); MICHAEL. STEPHEN HINDUS ET AL.. THE FILES OF THE MASSACHUSETtS 
great transformations of American law. ${ }^{537}$ It did not respond simply to the booming population growth of this era, but rather to the mechanization of production and transportation and to the human carnage wrought by massive but still-primitive machinery deployed by industrialists and railroad barons bent on profit and untethered by government safety regulations. ${ }^{538}$ Between 1880 and 1900 , the number of negligence suits filed

SUPERIOR COURT, 1859-1959, at 193 (1980) (showing an increase in the civil caseload of Suffolk County from 24,785 cases in $1860-1869$ to 52,293 cases in $1890-1899$ to 115,784 cases in 1920 1929). Because both the civil and criminal caseloads of Suffolk County seem to have been several times greater than those of Middlesex, which apparently was its closest competitor. what happened in Suffolk probably influenced judges' behavior more than events elsewhere. Two of the smaller counties actually saw their civil caseloads shrink in this time frame. See id. at 190, 192 (reporting that Berkshire County's civil caseload fell from 4374 to 2202 between 1860-1869 and 1890-1899 and that Hampshire County's fell from 1453 to 1400 after rising as high as 3179 in 1870-1879).

Although I have seen no study that measures the time consumed by civil caseloads in jurisdictions outside Massachusetts, several studies have measured the number of cases filed. The results generally do not show so steep an increase in civil filings as in Massachusetts, and some even show declines. See, e.g., RANDOLPH E. BERGSTROM, COURTING DANGER: INJURY AND LAW IN NEW YORK CITY, 1870-1910, at 16 (1992) (showing, on the basis of sampling, a decline in civil filings in the New York City Supreme Court from about 5110 in 1870 to 4740 in 1890 and then a rise to 6150 in 1910); Marc Galanter, Reading the Landscape of Disputes: What We Know and Don't Know (and Think We Know) About Our Allegedly Contentious and Litigions Society. 31 UCLA L. REV. 4, 40 (1983) (citing a study showing that the rate of civil filings in Mendard County, Illinois, measured in terms of cases per thousand people, fell from 16.4 in 1870 to 5.5 in 1890). Galanter often reports the rate of civil cases filed because he examines our society's litigiousness. For my purposes, however, the important question is the burden on courts, which might be something very different. For example, Galanter cites a study of St. Louis that shows a sharply falling rate of civil litigation at a time when the number of civil cases filed was rising healthily. See id. at 39.

537. See LAWRENCE M. FRIEDMAN, A History of AmERICAN LAw 339 (1973); JAMES WILLARD HURST, THE GROWTH OF AMERICAN LAW: THE LAW MAKERS 149-50 (1950).

538. See HINDUS ET AL., supra note 536, at 139 ("The rise of tort actions came about in large measure because of technological changes in the means of transportation."); ROSCOE POUND, ORGANIZATION OF COURTS 200 (1940) ("[T]he transition to a mechanical era [after the Civil War] led to the rise of the law of torts as one of the great subjects of the law."); ROBERT $A$. SILVERMAN, LAW AND URBAN GROWTH: CIVIL LITIGATION IN THE BOSTON TRIAL COURTS, 1880-1900, at $167 \mathrm{n} .7,187 \mathrm{n.14}$ (1981) (reporting the appearance of such texts as The Law of Railroad Accidents in Massachusetts (1897) and The Law of Passenger and Freight Elevators (1896)); id. at $191 \mathrm{n} .47$ (noting that the number of tort cases filed in Boston's courts against street railways rose from 15 in 1880 to about 1400 in 1900); $i d$. at 109 (reporting a rise in negligence cases against gas utilities from "a handful" in 1880 to about 400 in 1900).

The Massachusetts legislature created wrongful-death actions for families of railroad workers in 1881, see Act of Apr. 12, 1881, ch. 199, $\S 1,1881$ Mass. Acts 521, 521; permitted employees or their survivors to sue for work-related injuries due to railroad negligence in 1883. see Act of June 16, 1883, ch. 243, $\S 1,1883$ Mass. Acts 532, 532; and extended wrongful-death actions to all survivors of work-related accidents in 1887, see Act of May 14, 1887, ch. 270, $\$ 2$. 1887 Mass. Acts 899,900 .

Not all of the increase in the Superior Court's business arose directly out of technological change. The number of negligence actions involving a fall or a falling object filed in Boston's courts rose from about 50 in 1880 to more than 600 in 1900. See SILVERMAN, supra, at 112. Moreover, the legislature shifted large chunks of judicial business from the Supreme Judicial Court to the superior court. In 1880 , it removed all jurisdiction over torts from the Supreme Judicial Court, see Act of Feb. 20, 1880, ch. 28, 1880 Mass. Acts 31, 31; in 1882, it gave the superior court equity jurisdiction concurrent with that of the Supreme Judicial Court. see Act of May 13, 1883, ch. 223, 1883 Mass. Acts 515, 515; and in 1887 gave the superior court exclusive 
in Boston jumped from about 120 to about $3300 .{ }^{539}$ As personal injury tort suits began to crowd out the nonpayment contract disputes that had been the staple of the court's civil diet, ${ }^{540}$ a kind of time-intensive litigation that turned on past events and cumbersome eyewitness testimony displaced the quick and orderly paper-based litigation of earlier times. ${ }^{\text {s1 }}$ And as lawyers tempted by large contingency fees began to sling shots at the State Street law firms that defended the railroads, streetcars, and textile mills, ${ }^{s / 2}$ the ravaging civil warfare so familiar today spread from courthouse to courthouse, and lawyers multiplied faster than the population..$^{543}$

But if the numbers represented in Figure 6 are clear, their lesson is less so. Why should judges who faced an explosion in civil litigation have chosen to acquiesce and take part in a prosecutorial invention that served to limit only their criminal workload? I believe the answer is that judges, like prosecutors, plea bargained because they could. Just as overworked prosecutors of the first three-quarters of the century charge bargained in liquor and murder cases because rigid penalty schemes gave them the leverage to do so, overworked judges of the last quarter of the century turned to plea bargaining for relief from their out-of-control civil caseloads,

jurisdiction over divorces and custody actions, see Act of May 31, 1887, ch. 332, 1887 Mass. Acts, 954, 954. The legislature also tried to relieve the superior cour of its civil case burden by shunting some of its jurisdiction to the lower courts. See Act of May 11, 1877, ch. 211, \$3, 1877 Mass. Acts 595, 596.

539. See SILVERMAN, supra note 538, at 113.

540. See HINDUS ET AL., supra note 536, at 138, 140 (showing that from 1875 to 1905, the proportion of tort cases in the civil docket of Suffolk and Hampshire counties rose from 7.1\% to $37.4 \%$, with continuing increases thereafter, while the proportion of contract cases fell from $80.6 \%$ to $50.5 \%$ during the same period); see also BERGSTROM, supra note 536, at 16-17 (reporting findings in New York City showing that tort cases consistently made up a proportion of "contested cases" roughly four times larger than their proportion of all cases betwcen 1870 and 1910).

541. See HINDUS ET AL., supra note 536, at 139 (“Tor actions were generally more subjective than the often clear-cut promissory note and simple debt cases that had dominated the docket in earlier decades."); SL VERMAN, supra note 538, at 135-36 (noting that plaintiffs were more likely to claim jury trials in personal-injury litigation, expecting "to win sympathy from their peers"); MOORFIELD STOREY, THE REFORM OF LEGAL PROCEDURE 51-52 (1911) (estimating that personal-injury suits took up at least three-quarters of the time allotted by Boston courts to jury trials).

542. See SILVEMAN, supra note 538, at 115-16 (reporting that at the turn of the century, the Boston Elevated Railway was the defendant in nearly $30 \%$ of all personal-injury suits in Boston and that a few law firms handled most of the defense work); id. at 118 (citing 1897 Boston Bar Association minutes expressing concem that contingency fees prompted the poor, in league with their lawyers, to bring unmeritorious negligence suits).

543. See FRIEDMAN \& PERCIVAL, supra note 135 , at 56 (noting that the American population grew by $97 \%$ between 1870 and 1900 , while the population of lawyers grew by $186 \%$ ); HiNDus ET AL., supra note 536, at 139 (noting the importance of contingency fees): SLlVERMAN, supra note 538, at 30 (noting that the membership of the Boston bar "nearly doubled" between 1880 and 1900); see also 1 CENSUS REPORTS: TWELFTH CENSUS OF THE UNITED STATES 24 tbl.4 (1901) (noting that the population of Suffolk County increased only 58\% between 1880 and 1900). 
because they had far greater power to coerce pleas on the criminal side than to induce settlements on the civil side.

In a criminal case, after all, the judge could make the defendant a hardto-refuse offer: He could promise the defendant a lenient sentence for her plea, and he could threaten a harsher sentence should the defendant choose trial and lose. In the great majority of cases, the judge's nearly wide-open sentencing discretion gave him the power to make good on both promise and threat, mediated only by the defendant's power to win acquittal from the jury.

In a civil case, in contrast, the judge's power to promise a palatable outcome to a party who agreed to settle extended only so far as his power to persuade the opposing party to go along. Likewise, his power to threaten an unhappy outcome to a party who risked trial and lost reached little further than his capacity to influence the. jury to deliver an unfavorable monetary award. It is true that the doctrine of remittitur gave judges the power to order a new trial unless a victorious plaintiff agreed to give up whatever portion of a jury's award the judge thought excessive. ${ }^{544}$ But Massachusetts law did not recognize additur in nineteenth-century tort cases, so judges could wield no similar power against defendants in personal-injury actions. ${ }^{545}$ And even remittitur was not a plenary power to reduce damages, analogous to the sentencing power in criminal cases, but rather an indirect power to threaten a new trial unless the plaintiff accepted the reduced judgment.

Though civil settlements surely were growing over our period-from $15.7 \%$ of cases in 1865 to $28.4 \%$ in 1895 to $41.9 \%$ in $1905^{546}$-no study I have seen attempts to discern the judge's role in this increase. Even if judges perhaps had the means to coerce settlement in some civil cases, they obviously did not succeed in keeping their civil workload within bounds. ${ }^{547}$

544. See MASS. REV. LAwS ch. 173, § 112, at 1569 (Wright \& Potter 1902); Shanahan v. Boston \& N.S. Ry., 193 Mass. 412,414 (1907). I would like to thank Bob Gordon for pointing out to me the importance of remittitur in this context.

545. The legislature approved the concept of additur only in 1945. See Act of July 10. 1945. ch. 578, § 1, 1945 Mass. Acts 590, 590. The word "additur" appears to have been used for the first time in a Massachusetts case in 1959. See Murach v. Massachusetts Bonding \& Ins. Co., 339 Mass. 184, 185 (1959). More than a century before, the state's high court had recognized the concept of enhancing damages in a contract action, where "the damages are capable of estimation," but suggested that judges should do so only very rarely in "actions for personal wrongs." Taunton Mfg. Co. v. Smith, 26 Mass. (9 Pick.) 11, 12 (1829); cf. Renée B. Leltow, New Trial for Verdict Against Law: Judge-Jury Relations in Early Nineteenth-Century America, 71 NOTRE DAME L. REV. 505, 554 (1996) (noting that in the United States in the early 19th century. "remittitur was more widely accepted than additur").

546. See HINDUS ET AL., supra note 536, at 148.

547. In both Suffolk and Hampshire counties, it took twice as long to resolve the average civil case in 1895 as in 1865 , and given the huge increase in the number of cases, there is no way the settlement rate could keep up with the increasing pressure on the docket. See id. at 150; supra notes 539,546 and accompanying text. In 1890, the governor complained to the legislature that despite a recent addition of two judges to the superior court bench. "the present volume of 
The spiking line in Figure 6 that represents civil workload shows how essential it was that judges use what means they had to encourage pleas on the criminal side.

Exactly how judges in criminal cases communicated their desire for pleas and conveyed their promises and threats to criminal defendants is something I will take up in a few pages. For now, the important point is that on the criminal side-and the criminal side only-both the judges' promises and their threats had the force to work their purpose.

\section{B. Principles: The Effects of Probation and Parole}

Even if judges came to feel the caseload pressure long felt by prosecutors, a principled judge nonetheless might have refused to commit himself to a particular sentence without first hearing all the information normally supplied by a trial or sentencing hearing. The legislature may have resolved any such conscientious objection to plea bargaining, however, when it institutionalized the public probation officer as a reliable and arguably impartial source of information about the defendant's background and alleged offense. ${ }^{548}$ The 1878 act that created a probation officer for Suffolk County charged that person with the "duty ... to attend the sessions of the courts of criminal jurisdiction ..., to investigate the cases of persons charged with or convicted of crimes and misdemeanors, and to recommend to such courts the placing on probation of such persons as may reasonably be expected to be reformed without punishment." 549 The 1880 act extending probation officers to the rest of the state required them "to

business is so great that it is difficult to obtain a trial of an action until a long time after its commencement." DIMOND, supra note 190, at 93 (quoting the govemor). In 1903, a different governor made a very similar statement. See id. at 98 . In 1909, the legislature was forced to creatc a commission "To Investigate the Causes of Delay in the Administration of Justice in Civil Actions." H. DOC. No. 1050, at 3-4 (Mass. 1910). Studies from other jurisdictions suggest that a good deal of the growth in civil settlements took place only in the 20th century. See Alber W. Alschuler, Foreword: The Vanishing Civil Jury, 1990 U. CHI. LEGAL F. 1, 2-5 (collecting studies).

548. I say "arguably" impartial because the carliest probation statute, that of 1878, provided that the probation officer "shall be under the general control of the chief of police" of Boston. Act of Apr. 26, 1878, ch. 198, § 1, 1878 Mass. Stat. 146, 147 (relating to probation in Suffolk County). Both the 1878 act and the 1880 Probation Act envisioned that probation officers might be appointed from the police force. See Act of Mar. 22, 1880, ch. 129. $\$ 1,1880$ Mass. Stat. 87. 87; $\$ 1,1878$ Mass. Stat. at 146. In fact. Boston's first public probation officer. Edward $H$. Savage, was the city's retiring police chief. See SAVAGE. POLICE RECORDS AND RECOLLECTIONS. supra note 489 , at xiii. The legislature gave the cours, rather than municipal authorities, the power to appoint probation officers by acts of 1891 and 1898. so that the probation officer perthaps became "in every way an officer of the Court." Act of May 28, 1\$91, ch. 356, § 1, 1891 Mass. Stat. 920, 920 (providing for the appointment of probation officers); see also Act of June 8, 1898. ch. $511, \S 1,1898$ Mass. Acts 474, 474-75 (providing for the appointment of probation officers in the superior court); Grinnell, supra note 300, at 612-14 (reviewing this history).

549. $\S 1,1878$ Mass. Stat. at $146-47$ (relating to placing on probation persons accused or convicted in Suffolk County). 
carefully inquire into the character and offence of every person arrested for crime" and assigned them "the special duty ... to inform the court, so far as is possible, whether a person on trial has previously been convicted of any crime." ${ }^{550}$ With this information in hand, a judge could settle on a sentence in good conscience without the court proceedings that once supplied the same information.

From the beginning, probation officers fulfilled the duties assigned them by these acts to gather information and relay it to the court. Boston's first public probation officer, Edward H. Savage, reported in 1881 on his investigatory activities the year before:

I have visited the City Prison every morning, taken a list of the names, and offences of those in custody, and the names of arresting officers, seen the prisoners at their cells, then repaired to the court, had interviews with officers and others interested, in order to be prepared to take action in any case that seemed to demand attention. $^{551}$

Several years later, Savage elaborated:

[I]t becomes the important duty of the [probation] officer to make a thorough investigation into the reputation and true character of the offender. It is not enough to learn what people say; but the officer should have a personal interview with the prisoner, study his disposition, his intentions, his constitutional make-up, and, as far as possible, learn the probabilities of reform. ${ }^{552}$

Savage repeated this investigatory course for 698 defendants in 1879 and for more than 3000 in 1882 and each of several years to follow. ${ }^{553}$

Of course, none of this well-collected information could have helped the court to reach an appropriate sentence unless the probation officer passed it on. And although both the 1878 and the 1880 statutes gave probation officers the duty to "recommend" to the courts which defendants should be placed on probation ${ }^{554}$-and no doubt envisioned that probation

550. $\S \S 3,11,1880$ Mass. Stat. at 89 .

551. SAVAGE, ANNUAL REPORT, supra note 489, at 7-8.

552. SAVAGE, PROBATION WORK FOR THE COUNTY OF SUFFOLK, supra note 489, at 15.

553. See id. at 14. At least one observer from the late 1890 s confirmed that Savage and his colleagues did as he claimed:

[Probation officers] visit the home or place of employment. They search the court records to see if it be the first offense. If circumstances warrant, they may recommend to the judge, who is largely guided by their report, that the person be either discharged at once or be put upon probation.

Frederick B. Allen, Prison Reform in MASSAChusetts 5 (Boston, Christian Soc. Union 1898).

554. See $\S \S 3-4,1880$ Mass. Stat. at $87 ; \S 1,1878$ Mass. Stat. at 147. 
officers would convey the results of their investigations at that timeneither statute made it clear whether probation officers could make those reports before conviction. ${ }^{555}$ It would have done little to assist plea bargaining if the judge heard the needed information only after a trial or guilty plea. The 1880 law's imposition of a "special duty [on] each probation officer to inform the court... whether a person on trial has previously been convicted of any crime" 556 surely seems to require a report before conviction, but a 1916 probation manual declared it to be "doubtful if even ... [this provision] authorizes such information to be given prior to a determination of guilt." 557 The manual adds that " $[w]$ ith this doubtful exception, the probation officer's duty in cases before the court begins after conviction." 558

The probation manual perhaps protests too much. Why instruct probation officers to withhold information from the court until after conviction unless there was pressure on them to do otherwise? An English observer's 1899 report to the House of Commons on the activity of Boston's probation officers seems to confirm our suspicions. The observer quoted from a "statement of the methods employed in carrying out his duties [that] was prepared for me by Mr. Keefe, the Chief Probat[ion] Officer," and that was "confirmed" by the presiding judge of the Boston courts:

The probation officer visits the prison daily at $70^{\prime}$ clock, a.m., talks with each prisoner, ascertaining the facts of his connection with the offence charged, his address, his former record (if any) and any information of benefit to the prisoner, keeping in mind the good of the Commonwealth.

The records of drunkenness are looked over, former arrests recorded and given to the presiding Judge for reference when the prisoner is called.

The assistant probation officers (in the cases of drunkenness) visit the homes each morning, reporting to the Judge, when the prisoner is called, facts ascertained at the homes. If the prisoner provides for his family and has steady work,... [he] is usually placed on probation....

555. By requiring probation officers to investigate "persons charged with or convicted of crimes" (the $1878 \mathrm{act}$ ) and "every person arrested for crime" (the $1880 \mathrm{act}$ ), the acts make it clear that the duty to investigate arises before conviction, but this language says nothing about the stage at which the probation officer should "recommend" probation to the cour. \& 3, 1880 Mass. Stat. at $87 ; \S 1,1878$ Mass. Stat. at 147 .

556. $\& 11,1880$ Mass. Stat. at 89 (emphasis added).

557. Id.

558. Commonwealth of Mass., Probation ManUal 17 (1916). 
... In many cases the Judge cannot get at the true facts when the case is presented to the Court and depends upon the probation officer's investigation in deciding the case. ${ }^{559}$

Contrary to the probation manual's admonitions, probation officers apparently disclosed a great deal of information to the court before conviction-information that might have gone far to ease the qualms of conscientious judges who thought it wrong to pass sentence with less than full information. Perhaps, therefore, we have come upon another way, beyond encouraging first offenders to plead guilty, in which probation assisted plea bargaining's rise.

The nineteenth century's other distinctive contribution to penal practices also may have eased judges' principled objections to plea bargaining. In 1870, a prominent meeting in Cincinnati of the American Prison Association, chaired by future President Rutherford B. Hayes, launched the indeterminate-sentencing movement in America. ${ }^{560}$ The reality of the indeterminate sentence, had it ever taken hold in its truest form, would have done much to wreck the plea-bargaining regime: If the judge had no other role than to dispatch the defendant to prison and if other authorities determined the date of release, then the only meaningful promise the judge could make in exchange for the defendant's guilty plea would have been to put the defendant on probation rather than send him to prison. Plea bargaining would not have died in such a setting-we already have seen that defendants often pled guilty to win a chance at probation-but neither would it have flourished, for no conscientious judge could promise to spare serious criminals from serving any time at all. In Part VII, I will return to this clash between plea bargaining and the indeterminate sentence to show how the plea-bargaining regime succeeded in putting down this challenge to its forward march.

559. Evelyn RugGles-Brise, SOME OBSERVATIONS ON THE TREATMENT OF CRIME IN AMERICA 20, 21-22 (London, Darling \& Son 1899) (quoting the chief probation officer of Boston) (emphasis added). On Ruggles-Brise, see 5 LEON RADZINOwICZ \& ROGER HOOD. A HISTORY OF ENGLISH CRIMINAL LAW AND ITS ADMINISTRATION FROM 1750: THE EMERGENCE: OF PENAL POLICY 596-99 (1986).

560. See Edward Lindsey, Historical Sketch of the Indeterminate Sentence and Parole System, 16 J. Crim. L. \& Criminology 9, 18-20 (1925). The Cincinnati meeting. known as the National Congress on Penitentiary and Reformatory Discipline, helped put indeterminate sentencing on the political agenda, but it was not the first American encounter with the concept. As early as 1839, George Combs, a Scottish philosopher, articulated a proposal for a truc indeterminate sentence. See NEWMAN, supra note 387, at 34-35 (quoting Combs). And a halfcentury before Combs, Philadelphia's Benjamin Rush had advocated a system in which there would be fixed penalties for crimes, but prisoners would not be told what they were. See BENJAMIN RUSH, AN ENQUIRY INTO THE EFFECTS OF PUBLIC PUNISHMENTS UPON CRIMINALS AND UPON SOCIETY 11 (Philadelphia, Joseph James 1787). I thank Al Alschuler for pointing me to this aspect of Rush's work. 
Now, though, it is important to see what sustenance plea bargaining drew from the principles of the indeterminate sentence. For even as the true indeterminate sentence fell to history's dust heap, ${ }^{561}$ the concept survived in corrupted forms, and its theoretical underpinnings proved more lasting than the institution itself. Those underpinnings were quite simple: First, punishment should look to the future and not the past. That is, the critical concern in arriving at a just sentence was not what the defendant had done, but when it would be safe again to release him upon the community. ${ }^{562}$ The second underpinning followed from the first: Because the judge, even after trial, knew little more about the defendant's capacity for reform than what one could learn from a study of his past behavior, the judge was distinctly unqualified to pass a fixed sentence. "It is absurd," wrote a former Massachusetts prison commissioner and a leading advocate of the indeterminate sentence in 1899 , "to suppose that any judge can tell in 1900 whether a criminal will or will not be fit to return to the community in 1905." 563

561. See infra note 730 and accompanying text.

562. See Warren F. Spalding, The Indeterminate Sentence: Its Histon and Development in the United States, in THE INDETERMINATE SENTENCE AND tHE PAROLE LaW: RePORTS PREPARED FOR THE INTERNATIONAL PRISON COMMISSION, S. DOC. No. 55-159, at 7, 13 (1899); Charlton T. Lewis, The Indeterminate Sentence, 9 Y ALE L.J. 17, 20-21 (1899).

563. Spalding, supra note 562, at 14; see also Conlon's Case, 148 Mass. 168, 169 (1889) (identifying Spalding as the Secretary of the Board of Commissioners of Prisons): ALLEN, supra note 553, at 9-10 ("The prevalent system ... is absurd. A convict is usually sentenced for a fixed period-supposedly determined by his crime. Apan from the difficulty of discriminating as to a man's guilt [is] the personal equation of the disposition and mood of different judges."); CualR WILCOX, THE PAROLE OF ADULTS FROM STATE PENAL INSTITUTIONS IN PENNSYLVANIA AND IN OTHER COMMONWEALTHS 9 (1927) (quoting S.J. May, an 1840s advocalc of the indeterminate sentence, as saying, "One of the greatest improvements in the administration of our penal code would be to withhold from the judges all discretion as to the time for which convicts shall be confined."); Lewis, supra note 562, at 17-18 ("Our penal codes ... leave it to the trial judge to fix the duration of imprisonment within [broad] limits according to his view of the criminal's deserts. This system has often been exposed as absurd in principle and as grossly wrong and injurious in practice.").

In 1899, an Ohio judge and advocate of indeterminate sentences expressed in mild terms the objections of other judges to the drift of the indeterminate sentence movement:

Some learned judges and statesmen hesitate to apply the principles of an indefinite sentence...., holding that the trial judge can better fix a correct limit of just punishment ... than can the officer who keeps the prisoner. These thinkers seem to be held by the principle that the confinement and punishment of the criminal must equal the character of the offense, and that no one but a commissioned judge should limit the time.

Martin Dewey Folleth, Aims of the Indeterminate Sentence, in THE INDETERMINATE SENTENCE AND THE PAROLE LAW, supra note 562, at 22, 22. In 1891, the Michigan Supreme Court declared unconstitutional a state law that had given judges the option to impose indeterminate prison terms. See People v. Cummings, 88 Mich. 249, 263 (1891). Although judges retained the right to impose definite sentences instead, the court condemned the statute because it appeared to transfer to a parole board "judicial power in determining the term of imprisonment." Id. at 251. The cour wrote that the trial judge is "the one person best calculated, from his knowledge of all the incidents and circumstances of the commission of the crime and of the character of the prisoner, to exercise a discretion in fixing the term of imprisonment." Id. at 253; see also Miller v. State, 149 Ind. 607, 628 (1898) (Jordan, J., dissenting) ("[T]he right to assess the punishment, and thereby 
No doubt this assertion of judicial incapacity to fix the right sentence aroused judges' indignation. Making matters worse, state legislatures in fact began to carve away at judicial sentencing authority. Massachusetts helped lead the trend: In 1857 and 1858, long before the Cincinnati Congress, the legislature provided for "statutory good time" - a fixed reduction from the judge's sentence that convicts could earn by their good behavior in prison. ${ }^{564}$ In 1880 , the legislature granted probation officers the power to recommend the release of any misdemeanant with less than six months left to serve and required the district attorney, not the judge, to approve the release under this act of any person sentenced in superior court. ${ }^{565}$ An 1884 law $^{566}$ permitted the prison commissioners to release any convict they deemed "reformed." 567 The legislature created its first almost-genuine indeterminate sentence in 1886 , but as judges could use this sentencing option or not as they pleased, the balance of sentencing power did not shift greatly ${ }^{568}$ Finally, by acts of 1894 and 1895 , the legislature put in place the parole regime that most of us know today as the "indeterminate sentence," which required judges to set minimum and maximum terms when they sent a convict to state prison and gave prison authorities the power to choose a release date between those bounds. ${ }^{569}$

The same English observer I quoted earlier expressed his astonishment at American parole laws that "violate[d] the fundamental principle that ...

fix the term of imprisonment provided, within the limits of the statute [is] a judicial function, of which the court ... cannot be deprived by the legislature."); NEWMAN, supra note 387, at 35 ("The main opposition to the enactment of indeterminate sentence laws came from the judges who were unwilling to relinquish their traditional privilege of fixing the time prisoners must serve.").

564. See Act of Mar. 24, 1858, ch. 77, 1858 Mass. Acts 58, 58 (jails and houses of correction); Act of May 30, 1857, ch. 284, $\S 1,1857$ Mass. Acts 72, 72 (state prison). Although New York and Tennessee instituted good-behavior reductions in 1817 and 1836, respectively. Ohio's 1856 law seems to have sparked the concept's adoption nationwide. See Act of Apr. 15. 1817, ch. 269, $\S \S 5,19,1817$ N.Y. Laws 310, 312, 316; Act of Apr. 8, 1856, $\$ 17,1856$ Ohio Laws 126, 133-34; Act of Feb. 20, 1836, ch. 63, \& 4, 1835-1836 Tenn. Pub. Acts 171, 171; see also FREDERICK HOWARD WINES, MONOGRAPH ON SENTENCES FOR CRIME $15 \mathrm{n} . *$ (Springfield, Ill., H.W. Rokker 1885).

565. See Act of Mar. 22, 1880, ch. 129, § 6, 1880 Mass. Acts 87, 88.

566. See Act of May 21, 1884, ch. 255, 1884 Mass. Acts 220.

567. See id. $\S \S 2,3,1884$ Mass. Acts at 227. The Governor and Governor's Council had to approve the release of any convict from state prison. See id.

568. See Act of June 24,1886 , ch. $323, \S 1,1886$ Mass. Acts 296 . The act required that sentences to the Massachusetts reformatory "not fix or limit the duration" of confinement, unless they exceeded five years, id., but judges had the choice of other institutions, and reformatory sentences proved to be much more the exception than the rule, see infra notes 734-735 and accompanying text. Even reformatory sentences of less than five years were not genuinely indeterminate by strict notions of the term, for the act capped confinement of such sentences at either two or five years, depending on the crime.

569. See Act of June 5, 1895, ch. 504, $\S \S 1-2,1895$ Mass. Acts 624,629 (requiring judges to impose minimum and maximum terms to the state prison and providing for release on parole at any time after the expiration of the minimum term); Act of May 26,1894, ch. 440, $\$ 1,1894$ Mass. Acts 492, 492 (providing for release on parole from the state prison at the expiration of two-thirds of the judge's sentence). 
the sentence of the court shall be the final arbitrament of the case." ${ }^{570} \mathrm{He}$ concluded that they sprang in part from a "want of respect for, and confidence in, the State's Judiciary." " 771 It is hard to imagine that American judges missed the slight these laws implied. To the extent that the gravity of their sentencing power had ever held them back from casting it among the lots of the gaming table, the considered judgment of legislators that the judges' word should not be the last must have weakened their resistance. Moreover, the knowledge that another authority would later adjust the sentences of the court must have made it seem at least a little less important to get those sentences exactly right.

Hence both probation and the indeterminate sentence eased judges' principled objections to engaging in plea bargaining's human trade. Even as probation officers supplied information that let judges set an appropriate sentence without hearing evidence, the principles of the indeterminate sentence released judges from their obligation to set that sentence with precision. With their moral guard down and with alarming civil caseloads pressing them to cut deals where they could, judges perhaps gave in to temptation and dealt.

\section{Pride: The Plea-Withdrawal Rule}

But how-that is, by what mechanism-did judges deal? How did they communicate to defendants the reward tendered in exchange for their plea? Several possibilities present themselves. The least offensive to those who would find repellent any scent of judicial coercion to forgo trial would be "implicit" plea bargaining, in which the defendant merely guessed, perhaps relying on the judge's past practice, that the judge's sentence would be more lenient after a plea than after trial. For an implicit-bargaining regime to have prompted the very high percentages of guilty pleas that we see in the last decades of the nineteenth century, judges' sentencing practices would have had to be highly predictable. It is hard to believe that so many defendants would have pled guilty without some sound assurance of a reward. Occasionally, the records reveal a stark pattern of sentencing that would support the conclusion that an implicit plea-bargaining regime was at work. The sentencing of defendants convicted of breaking and entering at the February 1890 session of the Middlesex Superior Court presents perhaps the best example I have found. Of the twenty defendants who pled guilty to that crime, eight received three-year sentences, and all the rest received less time or no time at all. Of the six defendants convicted of that crime after trial, only one got less than three years (twenty-four months),

570. RUGGLES-BRISE, supra note 559, at 17 (quoting Rush).

571. Id. 
while one got three years, and the four others got substantially more. ${ }^{572}$ It seems possible that the court adhered to an understood practice that imposed a three-year cap on breaking-and-entering sentences for defendants who pled guilty and a three-year floor for defendants who demanded trial and lost. ${ }^{573}$

But although the last decades of the century were marked by very high rates of guilty pleas across most categories of crime, I have not seen stark sentencing patterns generally. In 1900, for example, fifty-four out of fiftyseven persons charged with breaking and entering pled guilty. ${ }^{574}$ Sentences for those who pled guilty ranged from simple filing and probation (thirty cases) to indeterminate sentences in the Massachusetts reformatory or reform school (eleven cases) to house-of-correction time averaging twelve months (thirteen cases). Of the three defendants who lost after trial, one found his case placed on file; one was sentenced to an indeterminate term at the Massachusetts reformatory; and one received twenty months in the house of correction. These results, more typical than the fairly clear pattern described in the last paragraph, suggest that something else besides implicit plea bargaining was probably at work to persuade so many defendants to plead guilty at the end of the nineteenth and beginning of the twentieth centuries.

That additional mechanism might have included an explicit promise by the judge to impose a certain sentence should the defendant plead guilty, perhaps combined with an explicit threat to impose a certain-or ominously uncertain-higher sentence should the defendant lose after trial. That judges today in many jurisdictions, including Middlesex, bargain for pleas

572. The four others received 48 months, 60 months, 63 months, and 72 months. See Commonwealth v. Maurice C. McCarthy, Middlesex Super. Ct. R. Book 146 (Fcb. 1890) (reporting a sentence of 48 months after trial and conviction in a breaking-and-entering casc); Commonwealth v. Arthur N. Neil, Middlesex Super. Ct. R. Book 101 (Feb. 1890) (same, 60 months); Commonwealth v. John Heffeman, Middlesex Super. Ct. R. Book 101 (Feb. 1890) (same, 63 months); Commonwealth v. Cornelius Sheehan, Middlesex Super. Ct. R. Book 101 (Feb. 1890) (same, 72 months).

573. Similarly, all four defendants who pled guilty to assault and battery in the October 1880 term of the Middlesex Superior Court received fines instead of prison sentences, while all three convicted of that crime after trial went to prison. See Commonwealth v. Michael Hennessy. Middlesex Super. Ct. R. Book 243 (Oct. 1880) (reporting an assault-and-battery case in which the defendant pled guilty and was fined but not imprisoned); Commonwealth v. Frederick Measures. Middlesex Super. Ct. R. Book 244 (Oct. 1880) (same); Commonwealth v. Jeremiah Ahern, Middlesex Super. Ct. R. Book 245 (Oct. 1880) (same); Commonwealth v. William L. Orcutt. Middlesex Super. Ct. R. Book 255 (Oct. 1880) (same); Commonwealth v. Christopher Flynn, Middlesex Super. Ct. R. Book 205 (Oct. 1880) (reporting an assault-and-battery case in which the defendant was sentenced to serve six months' time after being convicted at trial); Commonwealth v. Daniel Driscoll, Middlesex Super. Ct. R. Book 227 (Oct. 1880) (same, 18 months); Commonwealth v. Patrick Ford, Middlesex Super. Ct. R. Book 228 (Oct. 1880) (same, eight months).

574. As I did earlier, see supra note 502, I am excluding home breaks to avoid the distortion of that more serious offense. 
directly with defendants or their counsel is beyond dispute. ${ }^{575}$ But although there is some evidence of judicial plea bargaining in the late nineteenth century, it is both thin and geographically far-flung. In 1880, the Missouri Supreme Court reported that a trial judge had spoken with the defendant's lawyers and had led them to believe "that if the defendant would plead guilty, he would receive the lowest punishment allowed by law." $" 776$ Similarly, the Michigan Supreme Court in 1884 condemned a trial judge's "imprudent" statement to defense counsel "that, if the respondent should plead guilty, I should view his case as one meriting less punishment than I should feel disposed to impose should he be convicted after a trial by jury." 577 Even in that case, the trial judge insisted that he had uttered the unfortunate words only after firmly rejecting several earlier appeals to predict what he would do in the event of a plea. ${ }^{578}$ And in Maine in the 1890 s, there is evidence that the justices of the supreme court, who still sat as local trial judges, permitted liquor dealers to avoid further prosecution under the state's prohibition law if they came into court once a year and paid a fine plus costs. ${ }^{579}$

The absence of much other evidence of explicit judicial plea bargaining of course does not mean that the practice did not take place elsewhere, perhaps even in Massachusetts. The condemnation of the Missouri and Michigan high courts would have encouraged judges to conceal the signs of such deals, just as they do today. ${ }^{580}$ Still, lacking all evidence of such a practice in Massachusetts, not only in court records but also in newspapers and other contemporary sources, I think it best to conclude that explicit judicial plea bargaining played no great role in the surge of guilty-plea rates that marked Middlesex County practice in the last decades of the nineteenth century.

A third pleading mechanism perhaps proved more potent than implicit plea bargaining in encouraging defendants to plead and yet spared judges the demeaning and disfavored role of hawking a deal. In the simpler version of this deceptively simple technique, the judge merely acceded to the sentencing recommendation of the parties. Although I have no precisely

575. Mather and others have reported the practice. See MATHER. supra note 489, at 31-32. 58. In my years as a Middlesex County prosecutor, I regularly witnessed judicial plea bargaining.

576. State v. Stephens, 71 Mo. 535,536 (1880).

577. People v. Brown, 54 Mich. $15,21.29$ (1884).

578. See id at 20.

579. See PEREGRINE WHITE, JOHN A. PETERS: A MEMOIR 35-36 (Bangor, n.p., n.d.). I thank David Gold for this reference.

580. In Middlesex County in the late 1980s and early 1990s, when I served as a prosecutor, judges in the district (lower) courts often stated the terms of their plea offers openly and on the record. Superior court judges were more discreet and usually proposed terms in chambers with only counsel present. Mather reports that Los Angeles judges avoided on-the-record barters and that lawyers adopted the verb "chamberize" for the process of cutting deals with the judge behind closed doors. See MATHER, supra note 489, at 31. 
contemporaneous evidence of this process at work, a description given to a committee of the Massachusetts Legislature in 1923 by a former assistant district attorney made the practice sound well-worn:

[T]he district attorney and his assistants call in police officers and government witnesses and get their stories. Then defendants' counsel are heard, and then, unless a trial is absolutely unescapable, a crime is disposed of by agreement between counsel and the judge is asked to rubber-stamp the agreement with his O.K. If there is the slightest doubt that he will do so the case goes off the list to await the time when a judge will be presiding who is not likely to be so independent.... The judge has, of course, the power to upset any agreed disposition that comes before him and to make his own full and independent investigation into the case and to use his own judgment, but if he does so he uses up much precious time and embarrasses the district attorney exceedingly. Any judge who has had experience with the administration of the criminal law is likely to follow unhesitatingly the recommendations of a district attorney whose judgment he trusts ... ${ }^{581}$

To modern ears, this plea-bargaining technique perhaps sounds so obvious as not to merit the label "technique," 882 yet its sheer simplicity masks its brilliance. It neatly disposed of four impediments to judicial plea bargaining. First, because all of the haggling over terms took place between counsel and out of the judge's presence, this technique did not dirty judicial hands as did explicit judicial plea bargaining. Second, because the defendant's ability to predict the judge's sentence turned on exactly one aspect of the judge's sentencing practice-whether he did or did not habitually follow the parties' sentencing recommendation-this technique gave defendants far more assurance of a particular sentence in exchange for their pleas than did implicit plea bargaining. As the passage quoted above suggests, lawyers quickly learned which judges presented not even "the slightest doubt" that they would go along. Third, unlike prosecutorial charge bargaining of the sort that took place in the liquor cases of the first

581. Grinnell, supra note 127 , at 8 (quoting from a report of the Massachusetts Judicature Commission of 1923, which in turn quoted from a letter by the former prosecutor).

Although I have no evidence that Massachusetts judges did (or did not) habitually follow the parties' sentencing recommendations in the late 19th century, I can at least report evidence that lawyers made specific sentencing recommendations to the court in this time frame. See Charles $P$. Stickney, BOSTON DAILY GLOBE, Mar. 5, 1879, at 1 (reporting a sentencing proceeding in superior court in which the defense lawyer appealed for a sentence in the house of correction rather than in state prison, and the prosecutor requested "the full sentence of the law-namely, five years in the state prison").

582. Albert Alschuler reported in the 1960 s that Houston judges generally did not participate directly in plea bargaining and instead adhered rigorously to prosecutors' sentencing recommendations. See Albert W. Alschuler, The Trial Judge's Role in Plea Bargaining (pt. 1), 76 COLUM. L. REV. 1059, 1060-65 (1976). 
half-century, this technique did not deprive judges of any of their cherished sentencing power-and therefore posed no threat to their pride. As the prosecutor said in the passage quoted above, "The judge has, of course, the power to upset any agreed disposition that comes before him ...." 383

Finally-and on the other hand-this technique usually protected prosecutors from judicial whimsy. I argued earlier that one disincentive to charge bargaining in murder cases was the prosecutor's lack of dexterity in formulating a precise sentence. It is likely that prosecutors did not happily trade the mandatory death penalty assigned to first-degree murder for the zero-to-twenty-year prison term assigned to manslaughter without some assurance as to where along this range the court's sentence would fall. And yet if the defendant refused to plead to the mandatory life penalty assigned to second-degree murder, there was no other option. A judge's rigid habit of following the parties' sentencing recommendation should have eased the prosecutor's mind. Something like this appears to have been at work in the 1892 murder prosecution of Raffaele Scorpio. The attorney general reported that the defendant's guilty plea to manslaughter "was accepted on condition that the maximum penalty would be taken without objection" - and the defendant indeed received the maximum of twenty years. ${ }^{584}$ Although the attorney general's use of the passive voice made it unclear whoprosecutor or judge- "accepted [the plea] on condition" of the maximum sentence, there is little doubt that he meant the prosecutor. Although in the last decades of the century, the attorney general tended to write his reports in the passive, in earlier decades he regularly noted that " $\Gamma$ " accepted the defendant's guilty plea. ${ }^{585}$

For all its brilliance, the technique of simply ratifying the parties' sentencing recommendations suffered from real shortcomings. Under such a regime, few defendants would have offered a plea unless they felt assured that the judge was among those who consistently "rubber-stamp[ed] the agreement." Any judge who fell outside this group must have faced a stream of litigants who wished only to postpone their business until the judge moved on to another jurisdiction. To preserve his reputation as one who went along with agreements, the judge had to go along almost all of the time, and so, despite the formal reservation of sentencing power in the judges' hands, judges may have felt that the district attomey had stripped them of that power. The assistant district attorney quoted above saw this much when he said, "It must irk to be a rubber-stamp." 386 And even if the

583. Grinnell, supra note 127 , at 8 .

584. Commonwealth v. Raffaele Scorpio (Bristol Super. Ct.), listed in Report of the Antomey General for Year Ending January 17, 1893, PUB. DOC. No. 12, at vi (Mass. 1893).

585. See, e.g., Commonwealth v. William McGrath, listed in Report of the Attomey General for Year Ending December 31, 1868, PUB. DOC. No. 16, at 4 (Mass. 1869) ("I accepted a plea of guilty of murder in the $2 d$ degree . ...").

586. Grinnell, supra note 127 , at 8. 
judge had reconciled himself to his rubber-stamp role, some defendants must have felt too mistrustful of his intentions to relinquish their trial right for anything less than a guaranteed concession. At bottom, this system offered the defendant no assurance against unpleasant surprise should the judge decide to disappoint all parties' expectations.

A small adjustment to the technique of accepting the parties' recommendation solved these problems without sacrificing the technique's other virtues. Long after the endpoint of this study, the Massac'iusetts Rules of Criminal Procedure formalized this adjustment by requiring each trial judge to advise a defendant who pleads guilty under a plea agreement "that he will not impose a sentence that exceeds the terms of the [prosecutor's] recommendation without first giving the defendant the right to withdraw his plea." ${ }^{87}$ Note how gracefully this rule can set even the most skittish defendant at ease without imposing any constraint on the trial judge. A judge who wants to encourage defendants to plead guilty need not slavishly bow to the prosecutor's sentencing recommendation. She can follow the prosecutor's sentencing recommendation-or not, as she pleases. She need merely permit the defendant to withdraw his plea when she disappoints his expectations. The rule therefore erases the prideful concerns of judges who balked at the prospect of sharing sentencing power with prosecutors within a plea-bargaining regime. At the same time that it gives judges complete discretion to impose any sentence authorized by law, the rule grants prosecutors full power to promise defendants an assured concession in exchange for a guilty plea. In a sense, then, and in violation of the laws of physics, the rule expands the sum total of sentencing power in the criminal courtroom.

It is no wonder that this plea-withdrawal rule or rules like it should have proved widely popular. In 1975 Congress amended Rule 11 of the Federal Rules of Criminal Procedure to provide that although the judge should not, of course, "participate in any [plea] discussions," the judge must, if she rejects the plea agreement of counsel, "afford the defendant the opportunity to then withdraw the plea." 588 Both the American Bar Association and the American Law Institute previously had recommended such a rule, and several states besides Massachusetts have taken their advice. ${ }^{589}$ There can be little doubt that the plea-withdrawal rule has contributed to the extraordinary dominance of plea bargaining in modern American courtrooms, where guilty-plea rates above ninety or even ninety-

587. MASS. R. CRIM. P. 12(c)(2).

588. FED. R. CRIM. P. $11(\mathrm{e})(1)(\mathrm{C}), 11(\mathrm{e})(4)$.

589. See Model Code of PRE-ARraignment Procedure $§ 350.6$ (1975): Standards RElating to PleAs OF GUILTY $§ 2.1$ (1968). 
five percent are common. ${ }^{590} \mathrm{~A}$ far harder question is whether this rule or some version of it played a part in pushing the guilty-plea rate in Middlesex County toward the ninety-percent mark in the closing decades of the nineteenth century.

There are several reasons to think it did not. The description of practice from the 1920 s quoted earlier surely gave no hint of ready permission to withdraw one's plea whenever the judge exceeded the district attomey's sentencing recommendation. Even as late as 1976, just a few years before Massachusetts adopted the plea-withdrawal rule as part of its new rules of criminal procedure, the Supreme Judicial Court refused to "break new ground" by requiring a judge to permit plea withdrawal whenever his sentence exceeded the district attorney's recommendation. ${ }^{391}$ More importantly, I have found very little Massachusetts-based evidence of such a rule at work during the time frame of this study. The Supreme Judicial Court repeatedly held in the nineteenth century that plea withdrawal is not a right, but may be permitted or not at the discretion of the cour..$^{52}$

On the other hand, the absence of contemporary evidence of the rule in Massachusetts is perhaps not conclusive, as I have found very little evidence at all of the specific procedures surrounding guilty pleas. None of the Supreme Judicial Court's several opinions on plea withdrawal addressed the situation that concerns us here, in which the defendant sought to withdraw a guilty plea after the court imposed a harsher sentence than the prosecutor recommended. ${ }^{593}$ It may be that the high court rarely saw such cases because trial courts routinely permitted withdrawal. Moreover, there is good reason to think that trial court records omitted mention of plea withdrawals when they took place. A Lowell newspaper reported in 1835 on a plea withdrawal that never appeared in the court's official records. ${ }^{594}$

590. See Heumann, supra note 146, at 515 n.l (citing studies): Langbein, supra note 519, at 9 n.11 (same).

591. See Commonwealth v. Taylor, 345 N.E.2d 695. 698 (Mass. 1976). Most, but not all, state courts that considered this issue in the 1960 s and 1970 s reached a similar result. See Alschuler, supra note 582 , at 1072 n.45.

592. See Commonwealth v. Ingersoll, I4 N.E. 449, 450 (Mass. 1888); Commonwealth v. Mahoney, 115 Mass. 151, 152 (1874); Commonwealth v. Winton, 108 Mass. 485, 485-86 (1871); Commonwealth v. Hagarman, 93 Mass. (10 Allen) 401 . 402 (1865).

593. All four of the cases cited in the previous note addressed a different fact scenario: The defendant pled guilty or no contest in a lower coun and then. on appeal for a trial de novo in superior court, sought to withdraw that plea and plead not guilty. Such defendants often wished merely to get the best deal that either court would give them on a guilty plea, but of course they needed to withdraw their eariier guilty pleas in order to have any leverage in the higher court. Judges often resisted such forum-shopping by refusing to allow plea withdrawal. The judges' refusal in this context says little about their willingness to permit plea withdrawal when doing so would facilitate standard (single-cour) plea bargaining.

594. On September 26,1835, the Lowell Courier's summary of the business of the count of common pleas included this small account: "Martin Murtoy, Lowell-Assault with a shoe knife and an attempt to kill and murder, Plea, Guilty; sentence-3 days solitary and 5 years in State Prison. Aftemoon, retracted his plea of guilty, pleaded not guilty, and stood for trial." Lowal. COURIER, Sept. 26, 1835, at 2. Both the record book and the docket book of the court of common 
Outside Massachusetts, evidence that the plea-withdrawal rule was in place in the late nineteenth century is compelling, if not conclusive. In 1889, Murat W. Hopkins, an Indiana practitioner, published an article on plea-withdrawal in the Criminal Law Magazine. ${ }^{595}$ Hopkins stated the rule in explicit terms:

If, by reason of any side agreement with the prosecuting officer, a defendant under a criminal charge enters a plea of guilty, a more severe sentence than that agreed upon should not be awarded; and if a sentence more severe than the one indicated be inflicted, the defendant should be allowed to withdraw his plea of guilty, and plead not guilty, if he desires. ${ }^{596}$

The assurance with which Hopkins announced this rule and its nearly exact echo of the modern form suggest that this was not merely his opinion of what the rule should be, but rather his observation of what the rule was. Yet of the three cases from two states that he cited in support of the rule, ${ }^{597}$ only a single 1888 opinion of the Indiana Supreme Court supplied a clear precedent. $^{598}$

pleas omit any mention of the Murtoy case in their reports of the court's September 1835 session. Murtoy appeared, however, in the records of the court's December session, at which a jury found him guilty of simple assault and battery but not guilty of acting with intent to kill, and the court sentenced him to a mere year in the house of correction. See Commonwealth v. Martin Murtoy, Middlesex Ct. C.P. R. Book 525-26 (Dec. 1835). For our purposes, the most significant aspect of the record is the clerk's summary of the case's procedural history, which notes only that Murtoy had appeared at the previous session of the court and pled not guilty and says nothing of his earlier guilty plea and sentencing. See id. at 525 ("This Indictment was found at the Court of Common Pleas holden [in] ... September last, when and where the said Martin Murtoy was set to the bar, and had this Indictment read to him, he said that thereof he was not guilty, and thence said Indictment was continued to this time."). The clerk's silence about Murtoy's earlier plea and plea withdrawal leaves us to suspect that, for all the records of the Middlesex courts disclose, defendants might commonly have offered guilty pleas only to withdraw them when dissatisfied with their sentence.

I have found occasional-but only occasional-cases in which the clerk did record the defendant's withdrawal of a guilty plea. See, e.g., Commonwealth v. Henry O'Hapgood, Middlesex Ct. C.P. R. Book 309 (Oct. 1847); Commonwealth v. Hosmer Lew, Middlesex Ct. C.P. R. Book 43 (June 1844).

595. See M.W. Hopkins, Withdrawal of Plea of Guilty, 11 CRIM. L. MAG. 479 (1889); see also N.Y. TIMES, Dec. 17, 1955, at 23 (identifying Hopkins as an Indiana lawyer and providing his first name).

596. Hopkins, supra note 595, at 480; see also 16 CoRPUS JuRIS Criminal Law (Plea of Guilty) $\S 730$ (1918) (noting that if the defendant pleads guilty under the belief, induced by the prosecutor, "that sentence less severe than the maximum allowed would be given, defendant should be allowed to withdraw the plea").

597. See Hopkins, supra note 595, at 480 (citing Myers v. State, 18 N.E. 42 (Ind. 1888); State v. Kring, 71 Mo. 551 (1880); State v. Stephens, 71 Mo. 535 (1880)). Hopkins's statement of the rule follows immediately upon and within the same paragraph as his discussion of Sanders $v$. State, 85 Ind. 318 (1882), but that case seems irrelevant to the rule.

598. In Myers, the defendant pled guilty based on assurances from the prosecutor, relayed by the sheriff, that "if he pleaded guilty his punishment should not exceed two years imprisonment ...." Myers, 18 N.E. at 42 . The defendant pled guilty and was promptly sentenced 
I have searched extensively (if not exhaustively) through the large number of plea-withdrawal cases of the late nineteenth and early twentieth centuries in search of other statements of Hopkins's rule. Although many courts endorsed a liberal attitude toward plea withdrawal generally, ${ }^{599}$ I discovered only three that considered the specific question at hand: whether a defendant who pleads guilty on the strength of a prosecutor's promised sentencing recommendation has the right to withdraw his plea if the judge exceeds that recommendation. These jurisdictions-Kentucky, Ilinois, and Georgia-hardly constitute an American consensus, but it is notable nonetheless that all three endorsed the plea-withdrawal rule more or less as Hopkins stated it. ${ }^{600}$

Despite the meager rewards of my search, I hope that something more than an Eastern bias lies behind my suspicion that an Indiana practitioner's interpretation of an Indiana court's opinion did not alone give rise to a rule that grew to have national influence. For now, though, until further evidence turns up, I must concede that the subtle brilliance of the pleawithdrawal rule and the ease with which it dispatched several of the difficulties inherent in judicial plea bargaining may have come into play only much later in plea bargaining's progress. The point is not critical to our story, for judges could have achieved much of the benefit of the rule merely by accepting as a matter of course the sentencing recommendations of prosecutors. By that simple means, they would have escaped soiling their own hands in the bargaining process and avoided overtly ceding sentencing power to prosecutors even as they offered defendants sufficient assurance

to ten years in state prison. See id. at 43 . The high court held that the trial judge abused his discretion in refusing to allow the defendant to withdraw his guilty plea. See id. at 44.

In Kring, the Missouri court considered a defendant's claim that he had pled guilty to second-degree murder based on his agreement with the prosecutor, "apparenuly sanctioned by the judge of the criminal court, that the sentence should not exceed ten years imprisonment." Kring. $71 \mathrm{Mo}$. at 552. The apparent participation of the court in the bargaining process of course makes this case very much unlike the ideal type envisioned by the rule-and unlike Myers-and would seem to give the defendant a plausible claim of fraudulent inducement. In fact, the court announced that this case was "precisely similar" to Siephens, in which the judge clearly had misled the defendant as to the consequences of his guilty plea, thereby justifying the defendant in seeking to withdraw the plea. See Hopkins, supra note 595, at 480 (citing Stephens, 71 Mo. at 535).

599. See, e.g., People v. Miller, 114 Cal. 10, 16 (1896) (“The law ... will permit a plea of guilty to be withdrawn if it fairly appears that defendant was in ignoranoc of his rights and of the consequences of his act, or was unduly and improperly influenced either by hope or fear in the making of it"); State v. Williams, 14 So. 32. 32 (La. 1893) ("The withdrawal of the plea of guilty should not be denied in any case, where it is in the least evident that the ends of justice will be subserved by permitting not guilty to be pleaded in its place."); Deloach v. State. 77 Miss. 691, 692 (1900) (" $[T]$ he defendant should be permitted to withdraw his plea of guilty, when unadvisedly given, where any reasonable ground is offered for going to the jury."): People v. Joyce, 4 N.Y. Crim. 341, 345 (Sup. C. 1886) ("Where a person accused of crime may, inadvertently or unadvisedly, plead guilty to an indicument, and afterwards apply for the privilege to withdraw that plea and plead not guilty, the leave is commonly granted ....").

600. See Griffin v. State, 12 Ga. App. 615, 624-25, 630-31 (1913); Sinte v. Walker, 250 Ill. 427, 432 (1911); Mounts v. Commonwealth, $89 \mathrm{Ky} .274,277-78$ (1889) (dictum). 
against unpleasant surprise to encourage a great number to plead guilty. As we saw earlier, at least by the 1920s a practice of ready judicial acceptance of the prosecutor's negotiated sentences was solidly in place in Massachusetts. This mechanism perhaps helped judges of the late nineteenth century overcome their prideful objections to the practice of plea bargaining just as an avalanche of tort suits threatened to bury their courts.

\section{EXPLAINING PLEA BARGAINING’s PROGRESS ELSEWHERE}

As our story turns the corner into the twentieth century, plea bargaining's victory appears largely complete. The desire to see cases plead out rather than go to trial, which had infected public prosecutors almost from their inception, now had spread to judges, whose power to dictate sentences reached much further. Plea bargaining therefore could break loose from the narrow bounds to which prosecutorial charge bargaining once had confined it. Meanwhile, the supposed reform of permitting defendants to testify at trial had left those defendants who had criminal histories with little hope of winning at trial and little choice other than to seek the best plea deal that they could get. With all of the system's powerholders now sharing a common interest in plea bargaining, trials grew exceedingly rare. The rate of guilty pleas, which had approached ninety percent in 1900, showed no sign of falling off by $1910{ }^{601}$ As we know from the history books, the rest of the century only advanced plea bargaining's dominance. ${ }^{602}$

Plea bargaining entered the twentieth century with all the staying power that comes from serving the interests of power-holders. Its course throughout the century proved to be one of consolidation of power, as institutions that might have threatened plea bargaining's dominance fell by the wayside and as others that fed plea bargaining's preeminence took hold. But before I proceed in Part VII to trace the outlines of plea bargaining's twentieth-century progress, it is important to reinforce the lessons of its nineteenth-century rise. For our work in Middlesex County will be of little use unless we can be sure that the principles of power that steered the course of plea bargaining's rise there operated in other times and places.

I do not mean that we should expect to find plea bargaining dominant throughout time or ascending along the same trajectory everywhere. The particular posture of institutional actors in Massachusetts-the statutes that constrained their powers and the caseloads they faced-had no exact twin anywhere else, and for every change to one of these features of our story, we can expect to find a corresponding change in the plot line. That is, if

601. See supra note 529.

602. See supra note 590 and accompanying text. 
prosecutors lacked the good fortune of a rigid penalty scheme and an unregulated power to nol pros, then we would not expect to see charge bargaining of the sort that Massachusetts prosecutors devised in liquor and murder cases. And if judges lacked the incentive of caseload pressure, then we would not expect to find them setting aside their principled and prideful objections to bartering away defendants' rights and sharing sentencing authority with prosecutors.

In this brief foray into other times and places, therefore, I will ask only two questions: Who stood to gain from plea bargaining, and did that actor have the power to make it happen? I hope to learn only whether the dynamic of powers and interests that we have seen at work in Middlesex County can help explain plea bargaining's absence where it was lacking and its success where it thrived. There will be a certain randomness to this survey, as it depends largely on the empirical research of others, who may or may not have been concerned to detect plea bargaining and whose interests may not have raised the questions that for our purposes need answering. Moreover, there are simply very few in-depth empirical examinations of court records, and most, like mine, focus on a fairly narrow swath of time and space-and not all on the same swath. The analysis that follows consequently must reach across both time and distance to seek out common elements in the dynamic of plea bargaining.

\section{A. Plea Bargaining's Absence in Earlier Times}

We may begin by asking why plea bargaining appeared only recently on the penal landscape. Of course, we cannot be sure that it did. My figures from Middlesex County show that guilty pleas were by no means uncommon in the late eighteenth century, the earliest period I studied. I argued in Part II that these early guilty pleas probably were not plea bargains in the sense that the defendant won some understood concession in exchange for his plea, ${ }^{603}$ but rather gestures of remorse or hopelessness or unsecured bids for judicial mercy. Still, other observers might read the data differently. As I know of no substantial empirical study of pleading practice in American criminal courts before the nineteenth century, there is no way to conclude with assurance that plea bargaining had no American foothold before then.

The understanding that plea bargaining is a latter-day phenomenon emerges more from English than American studies and most particularly from the work of Malcolm Feeley and John Langbein, who are among the very few to have looked for evidence of plea bargaining in eighteenth-

603. See supra notes $181-184$ and accompanying text. 
century English court records.$^{604}$ Both Feeley and Langbein report that they found no sign of plea bargaining at London's Old Bailey court. They argue that the very unmodern brevity of eighteenth-century trials, a handful of which fit into the average court day, removed modern temptations to shortcut trial procedures with rough-and-ready plea bargains. ${ }^{605}$ And in fact, Feeley's evidence that the length of the average trial at the Old Bailey more than doubled in the late nineteenth century just as substantial numbers of criminal cases began to end in guilty pleas ${ }^{606}$ accords with my evidence from Massachusetts in the 1890 s, when both the length of the average murder trial and the proportion of murder cases ending in plea bargains increased sharply.

I agree with Feeley and Langbein that there was little or no plea bargaining at the Old Bailey in the eighteenth century-my own review of that court's business in 1715 and 1774 confirms as much. I am less inclined to agree that brevity of trials was the cause. That is in part because, as we will see shortly, plea bargaining occasionally does turn up in this era, and when it does, there is no sign of unusually long trials. More importantly, there is an explanation for the absence of plea bargaining that is so powerful as to eliminate the need for any other: Except in state trials such as treason, no public prosecutor took part in eighteenth-century criminal cases. Not until 1879 did Parliament institute public prosecutors to manage other felony cases. ${ }^{607}$ In the eighteenth century, no matter how serious the case, the crime victim or her survivors managed the prosecution. And not until the very end of the century did any substantial proportion of crime victims even hire private lawyers to manage the proceedings in court. ${ }^{608}$

604. See Malcolm M. Feeley, Legal Complexity and the Transformation of the Criminal Process: The Origins of Plea Bargaining, 31 ISR. L. REV. 183 (1997); Feeley \& Lester, supra note 437; Langbein, supra note 425, at 262-65; see also J.M. BEATTIE, CRIME AND THE COURTS IN ENGLAND, 1660-1800, at 336-37 \& n.52 (1986) (observing that only about $1.5 \%$ of larceny defendants pled guilty in the courts of Surrey between 1722 and 1802 and concluding that "[t]here was no plea bargaining in felony cases in the eighteenth century").

605. See Feeley, supra note 604 , at $190,202-05$; Langbein, supra note 425 , at $262-65$. Feeley reports that through the first half of the 19th century, a single judge and jury in London's Old Bailey court could hear between two and a half and almost five trials per day. See Feeley, supra note 604, at 203 fig.5.

606. See Feeley, supra note 604, at 199 fig.3, 203 fig.5. Feeley, however, might object to setting his findings in this light. Even as he emphasizes the increasing length and complexity of the average trial, a trend that moved almost in step with the advance of plea bargaining, see id. at 199 fig.3, 202-18, he disclaims any role for "increased case load pressures" in the rise of plea bargaining, id. at 204. But longer trials surely increased caseload pressure. Feeley's point is apparently that we should seek out the mechanisms and not merely the motives of plea bargaining's rise.

607. Even then, they appeared only in a limited form. See Prosecution of Offences Act. 1879. 42 \& 43 Vict., ch. 22; Philip B. Kurland \& D.W.M. Waters, Public Prosecutions in England. 1854-79: An Essay in English Legislative History, 1959 DUKE L.J. 493, 550-62.

608. See Feeley, supra note 604, at 195 fig.1. Feeley measured counsel representation at the Old Bailey at 20-year intervals. Except for the anomalous year 1795, when lawyers appeared for 
My work in Middlesex makes it plain that public prosecutors were the most important actors in the early days of plea bargaining. They had, first of all, the incentives to bargain: They wanted to win, and their workload pressures and part-time status made them want to win quickly. And they had, in limited contexts, the power to bargain. Whatever their incentives, crime victims in eighteenth-century English courts simply lacked the pleabargaining power of Massachusetts prosecutors. In particular, they lacked the power to nol pros. The only officer in the kingdom with the authority to enter a nol pros and terminate prosecution was the attomey general. ${ }^{609}$ As the attorney general appeared only in the occasional case of treason or other offense against the state, there normally was no authority in the courtroom who could summarily end the prosecution or reduce charges in exchange for the defendant's guilty plea.

Given the utter lack of prosecutorial bargaining power in most cases, the absence of plea bargaining perhaps should not surprise us. And yet, the Massachusetts experience suggests that the will to bargain often led to the way. Crime victims in eighteenth-century England probably had the will to bargain, as they had at least three incentives to do so. The first was money. Crime victims had to front the often considerable cost of transporting witnesses and lodging them near the court. Even if the court later reimbursed these expenses, the short-term hardship to many victims must have been great. The second incentive was time. Even if individual trials flashed by, victims and their witnesses waited hours and perhaps days for their cases to be called-and time cost money, both in lost income and in extra nights' lodging for witnesses. The third was risk of loss. More than one-third of prosecutions mounted at London's Old Bailey court in the eighteenth century ended in acquittals. ${ }^{610}$

the prosecution in over $70 \%$ of cases, the figure did not exceed (or often approach) $20 \%$ until 1855. See id.

609. See Regina v. Dunn, 1 C. \& K. N.P.R. 730, 731 (Q.B. 1843); Rex v. Cranmer. 88 Eng. Rep. 1578 (KB. 1702); 1 JOSEPH CHITTY, A PRACTICAL TREATISE ON THE CRIMINAL LAW * 479 (Philadelphia, Isaac Riley 1819).

610. Thirty-six percent of prosecutions ended in acquittals in 1715 and $43 \%$ in 1774 . See THE PROCEEDINGS OF THE SESSIONS OF THE PEACE, AND OYER AND TERMINER, FOR THE CTTY OF LONDON, \& COUNTY OF MIDDLESEX [hereinafter OBSP] (London, Joseph Gumey 1758) (1715; Apr. \& Sept. 1774). I am excluding from these figures cases that ended in acquittal because the prosecutor never appeared for trial. I have counted as guilty verdicts those cases in which the jury convicted the defendant of a lesser crime than that charged in the indictment. Figures cited for 1715 represent every case heard at the Old Bailey that year, those for 1774 represent only two of the eight sessions for that year (April and September).

These figures and others I cite throughout this Section may differ from seemingly similar statistics of business at the Old Bailey that I presented in an earlier aricle. See Fisher, supra note 488 , at 638-50. Because my aim there was to focus on the decisionmaking of juries, I excluded from consideration cases not decided by the jury either because the defendant pled guilty or because the judge directed a verdict of not guilty (or might have done so). See id. at $640 \mathrm{n} .295$. In particular, the rate of acquittals cited in the text here is far higher than that I cited in the earlier article, see id. at $641 \mathrm{n} .299$, because in a good many cases that ended in acquituals, it was unclear 
Whether for these reasons or for others, crime victims did bargain in ways that their limited powers permitted. Even without the nol pros, they had one way to reward those defendants who chose to bargain: They could fail to show up for trial and thereby guarantee that the court would find the defendant not guilty. ${ }^{611}$ That victims sometimes accepted cash from defendants in exchange for their nonappearance is clear, ${ }^{612}$ but measuring the frequency of such bargains is difficult. Victims abandoned prosecution in about five percent of cases before the Old Bailey in 1715 and in about two percent of cases in 1774, but whether they did so in exchange for payment or for some other reason does not appear in the case reports. Moreover, any bargains that took place before charges were filed do not show up in the case reports at all. In any event, this was a clumsy sort of bargaining, with narrow application. Victims of serious crime presumably wanted more justice than they could get in cash from often destitute defendants, and authorities condemned this way of resolving cases as against the public interest. ${ }^{613}$ Indeed, settling-or "compounding"felonies out of court was itself a crime..$^{614}$

There was a more nuanced way for crime victims to use the power to abandon prosecution, but it was not possible in every case - and it required some sophistication to devise and carry off. The French jurist Charles Cottu wrote of the "incredible transaction[s]" he witnessed in English forgery cases in the early nineteenth century. ${ }^{615}$ Cottu explained that lawyers for the victimized banks would seek two indictments against each alleged forger. One indictment charged the capital crime of forgery, and the other charged

whether the judge or jury decided the outcome. I therefore excluded these cases from my carlier study.

611. See, e.g., Regina v. Jeremiah Stamford, OBSP, supra note 610, at 184 (Feb. 23, 1780. No. 3, Pt. 3) ("The prosecutrixes were called but not appearing . . . Not Guilty."): Regina v. Sarah Jackson, OBSP, supra note 610, at 4 (Jan. 14-17, 1715) ("But there being no Prosecution. she was acquitted.").

612. See David D. Friedman, Making Sense of English Law Enforcement in the Eighteenth Century, 2 U. CHI. L. SCH. RoundTABLE 475, 486-92 (1995) (discussing the significance of the practice of "compounding" felonies, by which prosecutor and defendant essentially settled their case out of court). Norma Landau recently published the results of her study of the prosecution of minor assault crimes at the Middlesex (England) quarter sessions in the mid- and late 18th century. See Norma Landau, Indictment for Fun and Profit: A Prosecutor's Reward at EighteenthCentury Quarter Sessions, 17 L. \& HIST. REV. 507 (1999). She found clear evidence that in the great majority of assault cases, the defendant paid cash to "satisfy" the prosecutor, who of course was the private crime victim. The justices used various means to persuade reluctant defendants to reach private financial settlements with the prosecutor. After settling with the prosecutor, most defendants pled guilty, and the court then assessed (though it did not always collect) a token finc. See id. at 515-29.

613. See 4 BLACKSTONE, supra note 427, at *363-64; George Fisher, Making Sense of English Law Enforcement in the Eighteenth Century: A Response, 2 U. CHI. L. SCH. ROUNDTABLE 507, 510-11 (1995).

614. See 4 BLACKSTONE, supra note 427 , at *133-34.

615. Charles Cottu, De L'Administration de la Justice Criminelle en ANGLETERRE, ET DE L'ESPRIT DU GOUVERNEMENT ANGLAIS 99 (Amo Press 1979) (1822). I thank $\mathrm{Al}$ Alschuler for pointing me to this account. 
the noncapital offense of possessing false notes with the intent to utter. Cottu reported that defendants who pled guilty to the latter offense were sentenced by the court to a term of transportation in an Australian penal colony. When the capital forgery charge then proceeded to trial, counsel for the bank would announce that he had no witness, and the jury would acquit the defendant as a matter of course.

The banks' lawyers showed the same kind of ingenuity in their role as private prosecutors that public prosecutors in Massachusetts showed in cobbling together plea-bargaining techniques with the unlikely tools at hand. Just as Massachusetts prosecutors overcame their limited power to dictate sentences, so the banks' lawyers made the best of the one sentencing tool they had-abandoning prosecution. But this practice was unlikely to spread much beyond forgery cases. Not all crimes lent themselves to multiple indictments, and not all crime victims could afford lawyers to think up such clever plea-bargaining techniques. Cottu's account suggests that plea bargaining was rare in this era in England not because there was no incentive to bargain-for the banks' lawyers apparently thought there was-but because private prosecutors generally lacked the legal tools and know-how to devise a plea-bargaining regime.

The absence of public prosecutors in England not only explains the general absence of prosecutorial charge bargaining of the sort we saw in Massachusetts, but goes some distance as well toward explaining the lack of judicial sentence bargaining. Nineteenth-century judges in Massachusetts rarely if ever took part directly in negotiating plea bargains. Instead, it appears that they participated in plea bargaining by ratifying the sentencing recommendations of the parties-a technique that spared them the indignity of bartering in public. But in England, before the advent of regular public prosecutors in the late nineteenth century, judges had no such screen behind which they could pull the levers of power. In London's Old Bailey, the court that both Feeley and Langbein studied most closely, judges' actions were particularly exposed to scrutiny, for that court's business was recorded in sometimes striking detail in the Old Bailey' Sessions Paper, which enjoyed both a popular and an official readership ${ }^{616}$-and which made possible Feeley's and Langbein's studies. Even judges who had the power and the incentive to plea bargain might have hesitated before so publicly trimming their workdays by trimming the trappings of justice.

In pointing to the absence of public prosecutors, therefore, I perhaps have said enough to explain the general absence of plea bargaining at the Old Bailey in the eighteenth century. Still, it is worth noting that the bench

616. See OBSP, supra note 610. On the Sessions Paper, see generally Simon Devereaux. The City and the Sessions Paper: "Public Justice" in London, 1770-1800, 35 J. BRTr. STUD. 466 (1966); and Langbein, supra note 425, at 267-72. 
of the Old Bailey appears also to have lacked any strong incentive to plea bargain. Between 1715 and 1774, the Old Bailey's caseload grew only from 495 to 697 - a rate of well below one percent per year. Even if one considers the increasing length of trials, from an average of about one-fifth of a court day in 1715 to about one-third of a day in $1775,{ }^{617}$ the increase in total case pressure over the course of three generations was rather mild. Nor does it seem that English judges of the eighteenth century faced an explosion of civil cases like that encountered by Massachusetts judges of the late nineteenth century. ${ }^{618}$ From all that appears, Old Bailey judges in this era had no particular motive to plea bargain.

If we now travel some 150 miles north from the Old Bailey, we can examine the business of a court that had a very different caseload profile and that operated in relative obscurity, far from the glare of the Old Bailey Sessions Paper or anything resembling it. The magistrates in and near Manchester presided at that town's court of quarter sessions, where various minor offenses were tried. Some years back, I studied the business of this court during the last quarter of the eighteenth century. Though my purpose at the time was to investigate changing modes of punishment, I stumbled upon unmistakable evidence of judicial plea bargaining.

The evidence emerges from the sentencing pattern in cases of petty larceny, which accounted for between seventy and eighty-three percent of all cases heard ${ }^{619}$ By law, the magistrates had discretion to punish petty larceny with either seven-year terms of transportation or up to two years in the house of correction. In the years that I sampled between 1774 and 1797, the magistrates passed sentence on 516 petty larcenists. Of the 369 who had chosen trial and lost, the justices sentenced 170, or almost half, to transportation. But of the 147 who had pled guilty, the justices sentenced not one to transportation and instead incarcerated all but a few. ${ }^{620}$ As the average house-of-correction term for petty larceny never much exceeded nine months, ${ }^{621}$ and as the prospect of a dangerous ocean-crossing and seven years abroad terrified many defendants, the justices' concession in imposing prison terms rather than transportation must have been more than enough to induce many defendants to plead guilty.

I have read many accounts of the court's business published in the Manchester Mercury, one of the leading local papers. The Mercury reported

617. See Feeley, supra note 604 , at 203 fig.5.

618. Such an explosion came later-in the $1810 \mathrm{~s}$ and 1820 s. There seems to be little evidence of sharp growth in civil caseloads before 1800. See C.W. Brooks, Interpersonal Conflict and Social Tension: Civil Litigation in England, 1640-1830, in THE FIRST MODERN SOCIETY: EsSAYS IN ENGLISH HISTORY IN HONOUR OF LAWRENCE STONE 357, 364 (A.L. Beier et al. eds., 1989).

619. See George Fisher, The Birth of the Prison Retold, 104 YALE L.J. 1235, 1252 n.62 tbl.5 (1995).

620. See id. at 1276.

621. See id. at 1265 tbl.7. 
in a summary way on the goings-on in court, supplying none of the factual or procedural detail of the Old Bailey Sessions Paper. ${ }^{622}$ Typically, it noted only the names of those called before the court, whether they were convicted or acquitted, and the sentence awarded. The magistrates therefore could feel secure that a bargaining practice that emerges clearly on close examination of the court's records perhaps escaped public notice and almost certainly escaped the attention of national authorities.

Unfortunately, the utter lack of public comment on the justices' bargaining practices means that we, too, lack information about the motive behind the method. Here again, the court's records shed light. At the same time that the practice of plea bargaining was advancing dramatically, the court's caseload was growing at a daunting pace, quadrupling in the course of a generation.

TABle 9. GuIlty Pleas In Cases of PetTy LaRceny at THE MANCHESTER (SALFORD) COURT OF QUARTER SESSIONS ${ }^{623}$

\begin{tabular}{|c|c|c|c|}
\hline Years & $\begin{array}{c}\text { Number of } \\
\text { Persons } \\
\text { Convicted }\end{array}$ & $\begin{array}{c}\text { Number of Guilty } \\
\text { Pleas }\end{array}$ & $\begin{array}{c}\text { Percentage of } \\
\text { Guilty Pleas }\end{array}$ \\
\hline $1774-1775$ & 42 & 3 & $7 \%$ \\
\hline $1781-1782$ & 48 & 8 & $17 \%$ \\
\hline $1786-1787$ & 109 & 25 & $23 \%$ \\
\hline $1791-1792$ & 143 & 31 & $22 \%$ \\
\hline $1796-1797$ & 174 & 80 & $46 \%$ \\
\hline
\end{tabular}

Source: George Fisher, The Birth of the Prison Retold, 104 YALE L.J. 1235, 1276 tbl.10 (1995).

Although it seems very likely that Manchester's magistrates began plea bargaining in petty larceny cases to help relieve the pressure of mounting caseloads, I do not believe they acted solely for this reason. It is possible they also had a principled basis for their bargaining. As a group, the magistrates believed ardently in prison reform and regarded prison as a place of reform. ${ }^{624}$ They may have believed that those defendants who confessed their guilt were better subjects for a reformatory prison regimen than those who contested guilt at trial. Such a belief would help account for

622. See, e.g., MANCHESTER MERCURY, Jan. 25, 1791, at 4 (reporing only in summary fashion on the results of cases heard at a recent sitting of the court of quarter sessions).

623. The Quarter Sessions Order Books, which are the only comprehensive and convenient record of the business of the Manchester cour, present convictions but not acquittals. See Fisher. supra note 619 , at 1249 n.49. Total convictions (including those for petty larceny) increased from 55 in 1774-1775 to 199 in 1796-1797. See id. at 1252 n.62 tbl.5.

624. See id. at 1258-67, 1271-76. 
the large jump in the proportion of guilty pleas that followed the opening in 1790 of the magistrates' new house of correction, designed and operated according to the most modern reforming principles. ${ }^{625}$ The magistrates may have wanted to fill their new prison with the most promising subjects for reform. As in Middlesex, then, we find that the bench responded both to caseload pressure and to more principled concerns about the purposes of sentencing.

Despite these moments of recognition, this short tour through eighteenth-century England has taken us past scenes that look quite different from nineteenth-century Middlesex County. But these differences do not undermine the lessons that emerged from Middlesex. If plea bargaining was rare in England before the late nineteenth century, so too were the conditions that proved in Middlesex to be essential to plea bargaining's rise. In the Old Bailey, where plea bargaining was wanting, we find that the relevant actors lacked either the power to bargain or the incentive to do so. But where plea bargaining does poke through the historical record-as it does in Cottu's account of forgery prosecutions in the early nineteenth century - we find behind the record a prosecutor with a motive to deal who contrived to find the power. And where we can find magistrates who had an incentive to bargain and the discretion to shape sentences-as we do in Manchester's busy court-we find them at work striking deals.

\section{B. Plea Bargaining's Rise Elsewhere in America}

Our task now is to examine whether these same principles of power and interest can help explain the course of plea bargaining's rise in American jurisdictions outside Massachusetts. Here the inquiry must focus on two states, California and New York, because I have found no substantial empirical study of sentencing practices before the twentieth century in any other jurisdiction. In any event, California and New York provide a useful sampling —one state far removed from Massachusetts both geographically and in cultural and economic development, and one state very much the same. In California, as we will see, plea bargaining progressed more slowly than in Massachusetts, while in New York it advanced faster. The information at hand is limited, so my conclusions cannot be certain. But all signs suggest that both California's late start and New York's precociousness trace to the different bundles of powers and interests held by each courtroom actor. 


\section{California}

Lawrence Friedman and Robert Percival's study of Alameda County 626 supplies most of what we know about criminal practice in California in the late nineteenth and early twentieth centuries. Their critical findings emerge from a sampling of superior-court case files from between 1880 and 1910.

TABle 10. IntTLal Pleas in CASES IN Which Defendants ENTERED PLEAS: ALAMEDA COUNTY, CALIFORNIA, 1880-1910

\begin{tabular}{|c|c|c|c|c|}
\hline \multirow[b]{2}{*}{ Year } & \multicolumn{3}{|c|}{ Initial Plea } & \multirow{2}{*}{$\begin{array}{c}\text { Number } \\
\text { of } \\
\text { Cases }\end{array}$} \\
\hline & Not Guilty & $\begin{array}{l}\text { Guilty as } \\
\text { Charged }\end{array}$ & $\begin{array}{l}\text { Guilty of Lesser Offense } \\
\text { or Fewer Counts }\end{array}$ & \\
\hline $1880-1889$ & $78 \%$ & $12 \%$ & $10 \%$ & 171 \\
\hline $1890-1899$ & $75 \%$ & $19 \%$ & $6 \%$ & 185 \\
\hline $1900-1910$ & $64 \%$ & $32 \%$ & $4 \%$ & 295 \\
\hline
\end{tabular}

Source: Lawrence M. Friedman \& Robert V. Percival. The RoOts of Justice: Crime and Punishment in Alameda County, California 1870-1910, at 174 tbl.5.12 (1981).

Three aspects of these figures stand out. First, the proportion of guilty pleas of all sorts was growing steadily and modestly from twenty-two percent in $1880-1889$, to twenty-five percent in $1890-1899$, to thirty-six percent in 1900-1910. Second, all these figures remained considerably below corresponding figures in Middlesex County Superior Court, where the guilty-plea rate for all cases was seventy-seven percent in 1880, eightyseven percent in 1900, and probably about the same in $1910 .^{627}$ Third, there was a "remarkable" increase, as Friedman and Percival call it, ${ }^{628}$ in the proportion of defendants who pled guilty to the charged offense as opposed to some lesser crime. At the same time, the proportion who pled to a lesser offense started small and grew even smaller.

We may begin by asking why the rate of guilty pleas should have been so much lower in Alameda than in Middlesex. If we look first (as we have done before) at the power of prosecutors, we come immediately to one obvious explanation: In 1851, the California legislature abolished the nol $\operatorname{pros}^{629}$ and thereby eliminated the district attorney's power to charge

626. See FRIEDMAN \& PERCIVAL, supra note 135.

627. As I explained earlier, the surviving records do not permit a complete analysis in 1910 . See supra note 529.

628. FRIEDMAN \& PERCIVAL, supra note 135 , at 179.

629. See Act of May 1, 1851, ch. 29, § 598, 1851 Cal. Stat. 212, 279 (“Neither the Attomey General [n]or the District attorney shall hereafter discontinue or abandon a prosecution for a public offence, except as provided in the last section."). The previous section provided that " [t]he Court may, either of its own motion or upon the application of the District attomey, and in 
bargain in the fashion of Massachusetts prosecutors in liquor and murder cases. In place of the nol pros, the legislature substituted a procedure for dismissing indictments, but put the power to dismiss in the judge's hands. Hence Friedman and Percival recount cases in which the district attorney and the defendant agreed that the defendant would plead guilty to one of several counts or to a lesser offense of the crime charged on condition that the balance of the indictment be dismissed-but the parties still had to convince the judge to enter the dismissal. "It was very, very rare for a judge to refuse," they write, but apparently not unheard of, for the authors mention one case in which the court refused to deal and another in which the court went along only with difficulty. ${ }^{630}$

Despite what Friedman and Percival see as the court's ready acquiescence in charge bargaining, the rarity of this bargaining technique suggests that prosecutors and defense lawyers did not like having to submit their carefully crafted agreements for court approval. After all, as Table 10 shows, the proportion of defendants who pled guilty to a lesser offense or to fewer counts than those charged stood at only ten percent at the outset of Friedman and Percival's study and promptly fell to six percent and then to just four percent-and this at a time when guilty pleas of all sorts were rising. Perhaps judges resisted participation in a process that so clearly implicated them in plea bargaining. The authors report one judge's demand that a defendant deny that he pled guilty as part of a plea bargain. Only after the defendant complied- "Oh no, sir. No, I would have pleaded guilty anyway." - did the judge dismiss the balance of the indictment in strict compliance with the plea bargain. ${ }^{631}$

But even if California prosecutors had wielded a unilateral power to charge bargain, they perhaps lacked sufficient incentive to mount a vigorous plea-bargaining practice. It is true that prosecutors in California, like prosecutors everywhere, must have valued plea bargaining to the extent that it delivered certain victory in individual cases. But Alameda prosecutors apparently carried a far lighter workload than those in Middlesex and consequently may have felt less time pressure to plead. In the period of Friedman and Percival's study, the Middlesex County criminal caseload ranged between four and eight times the size of that in

furtherance of justice, order any action or indictment to be dismissed; but in such case the reasons of the dismissal shall be set forth in the order, which must be entered on the minutes." $I d . \S 597$. 630. FRIEDMAN \& PERCIVAL, supra note 135 , at 177-78.

631. Id. at 178 . 
Alameda ${ }^{632}$ Meanwhile, the legal staff of the Middlesex district attorney's office appears to have consisted of just the district attorney and one assistant prosecutor as late as $1898 .^{633}$ In Alameda, although the district attorney worked alone as late as the 1870 s, there were three lawyers on staff by 1885 , six by 1901 , and nine by $1910 .{ }^{634}$ Still, these prosecutors did not work full-time, and the district attorney and two of his assistants even joined together in a civil-law partnership in $1893 .{ }^{635}$ As I argued earlier, part-time prosecuting inevitably generated financial incentives to dispose of criminal cases quickly, no matter how small the prosecutorial workload.636

But lacking the nol pros power, prosecutors who hoped to plea bargain had to win the cooperation of judges. In Massachusetts at the time of Friedman and Percival's study, judges were becoming full-fledged partners in the plea bargaining regime. If California judges were of the same mind, then we might expect to see far more plea bargaining there than we do. But in fact, Alameda judges probably felt far less incentive to bargain than did Middlesex judges. In 1900, when the criminal caseload of Middlesex County was about eight times that of Alameda, ${ }^{637}$ there were eighteen superior-court judges in Massachusetts who rode circuit among the state's fourteen counties. ${ }^{638}$ They devoted a total of 325 judge-days to Middlesex County business-the equivalent of perhaps one and one-half full-time judges-and only forty-four days to the county's criminal calendar. ${ }^{639}$ In contrast, four full-time superior-court judges sat permanently in Alameda. ${ }^{6+0}$ Friedman and Percival do not measure the judges' civil caseload, but Friedman reports elsewhere that it was quite small: Between 1880 and

632. Our findings are as follows:

CRMMINAL CASELOAD IN ALAMEDA AND MidDLESEX COUNTIES

\begin{tabular}{|c|c|c|}
\hline YEAR & ALAMEDA COUNTY & MIDDLESEX COUNTY \\
\hline 1880 & 117 & 486 \\
\hline 1890 & 78 & nol measured \\
\hline 1900 & 75 & 602 \\
\hline 1910 & 185 & nol measured \\
\hline
\end{tabular}

Sources: FRIEDMAN \& PERCIVAL, supra note 135, at 41 tbl.3.1; Middlesex Super. Ci.

R. Books; Middlesex Super. Ct. Docket Books.

The Middlesex figures for 1880 are projected from a study of one of the three terms of the court. 633. The Massachusetts Lawyer's Diary for that year identified Frederick N. Wier as the Middlesex district attorney and George A. Sanderson as his only assistant. See MASSACHUSETTS LAWYER'S DIARY 15 (1898). The records of the Middlesex Superior Cour for 1910 noted the appointment of Henry C. Sawyer as "Second Assistant District attomey" of Middlesex. but gave no hint whether the office was newly created or whether there might also have been a third assistant district attomey. Middlesex Super. Ct. R. Book 325 (1910).

634. See FRIEDMAN \& PERCIVAL, supra note 135, at 50.

635. See id. at 50-51.

636. See supra notes $132-137$ and accompanying text.

637. See supra note 632.

638. See supra note 518.

639. See supra note 527 and accompanying text

640. See FRIEDMAN \& PERCIVAL, supra note 135, at 46-48. 
1900, there were on average only seventeen personal-injury suits filed each year in Alameda County Superior Court. ${ }^{641}$ Two facts now seem clear: Alameda courts had about three times the judicial resources of Middlesex courts and a caseload many times smaller. The conclusion is irresistible that the pressure to plea bargain weighed far more heavily on the Massachusetts judges.

Finally, there is good reason to think that California criminal defendants, like California prosecutors and judges, had milder incentives to plea bargain than did their counterparts in Massachusetts. We saw in Massachusetts that two factors-the rate of counsel representation and the right to testify at trial-influenced defendants' changing inclination to plea bargain in the nineteenth century. The distinction between California and Massachusetts defendants did not lie in the right to testify at trialdefendants in each state won that right at virtually the same moment. ${ }^{642}$ To the extent that defendant-testimony laws discouraged some defendants from opting for trial, therefore, they probably operated similarly in both states.

But while Massachusetts provided free lawyers only for those defendants charged with capital crimes, ${ }^{643} \mathrm{California}$ provided free counsel for all indigent defendants facing felony trials. ${ }^{644}$ Probably as a result, the proportion of defendants with counsel in Alameda Superior Court ranged between eighty-three and eighty-nine percent over the period Friedman and Percival studied, ${ }^{645}$ while in Middlesex County in the same period the figure hovered below fifty percent. ${ }^{646}$ We saw earlier that having a lawyer in Massachusetts greatly increased defendants' chances of winning at trial and considerably increased the odds that they would go to trial rather than plead guilty ${ }^{647}$ It may be true that appointed counsel in California, who received no fee for their services, ${ }^{648}$ were not the best, ${ }^{6+9}$ and it appears to be true that Alameda County defendants did not always fare better at trial than

641. See Lawrence M. Friedman, Civil Wrongs: Personal Injury Law in the Late 19th Century, 1987 AM. B. FoUND. RES. J. 351, 359.

642. See supra note 455 .

643. See supra note 439 and accompanying text.

644. See FRIEDMAN \& PERCIVAL, supra note 135 , at 170.

645. See id. at 171. Friedman and Percival report that at least one-quarter of the defendants in their sample had appointed counsel, but they cannot fix the proportion precisely. See id.

646. See supra note 436 and accompanying text.

647. See supra notes $441-442$ and accompanying text.

648. See FRIEDMAN \& PERCIVAL, supra note 135 , at 172.

649. See id. at 171 n.60 (quoting a 1926 study concluding that most assigned lawyers were either young and inexperienced or older and presumably unable to attract better-paying business). 
Middlesex County defendants despite their higher representation rate. ${ }^{650}$ But we nonetheless may expect that defendants with lawyers more commonly saw their chances of victory at trial as justifying the risk. If so, then the higher representation rate in California may help explain Alameda's lower guilty-plea rate.

With California prosecutors lacking the unilateral power to charge bargain and with all three courtroom actors lacking motives to bargain as strong as those in Massachusetts, it is probably no surprise that plea bargaining showed far less vigor in late-nineteenth-century California than in late-nineteenth-century Massachusetts. We should turn, then, to Friedman and Percival's "remarkable" finding that over the course of their study, the proportion of defendants who pled guilty to the charged offense increased from twelve to thirty-two percent. ${ }^{651}$ I believe we can find an explanation in a procedural change that took place at the very outset of Friedman and Percival's study and that supplied prosecutors with a chargebargaining tool that stood in for the abolished nol pros.

In 1880, the California legislature established the "preliminary examination" as an alternative charging mechanism to the grand jury, and prosecutors quickly abandoned the grand-jury process. ${ }^{652}$ As over half of all defendants had counsel at their preliminary examination, ${ }^{653}$ the examination gave the prosecutor and defense lawyer a built-in opportunity to meet and

650. Although it is difficult to compare my figures directly with Friedman and Percival's, it appears that at the beginning of their period, the rate of acquittal at trial was considerably higher in Alameda than in Middlesex, but that by the end of their period, Middlesex defendants fared better:

VERDICTS AT TRIAL

\begin{tabular}{|c|c|c|c|c|c|c|c|}
\hline \multicolumn{4}{|c|}{ ALAMEDA COUNTY } & \multicolumn{4}{|c|}{ MIDDLESEX COUNTY } \\
\hline Years & $\begin{array}{l}\text { Guilty of } \\
\text { Charged } \\
\text { Offense }\end{array}$ & $\begin{array}{l}\text { Guilty } \\
\text { of } \\
\text { Lesser } \\
\text { Offense }\end{array}$ & $\begin{array}{l}\text { Not } \\
\text { Guilty }\end{array}$ & Year & $\begin{array}{l}\text { Guilty of } \\
\text { Charged } \\
\text { Offense }\end{array}$ & $\begin{array}{l}\text { Guilty } \\
\text { of } \\
\text { Lesser } \\
\text { Offense }\end{array}$ & $\begin{array}{c}\text { Not } \\
\text { Guilty }\end{array}$ \\
\hline $\begin{array}{l}1880- \\
1889 \\
\end{array}$ & $36 \%$ & $15 \%$ & $39 \%$ & 1880 & $64 \%$ & $5 \%$ & $23 \%$ \\
\hline $\begin{array}{l}1890- \\
1899\end{array}$ & $33 \%$ & $17 \%$ & $40 \%$ & 1890 & $60 \%$ & $5 \%$ & $33 \%$ \\
\hline $\begin{array}{l}1900- \\
1910\end{array}$ & $42 \%$ & $16 \%$ & $30 \%$ & 1900 & $44 \%$ & $8 \%$ & $45 \%$ \\
\hline & & & & 1910 & $44 \%$ & $9 \%$ & $47 \%$ \\
\hline
\end{tabular}

Sources: FrIEDMAN \& PERCIVAL, supra note 135, at 182; Middlesex Super. Ct. R. Books; Middlesex Super. Ct. Docket Books.

Percentages may not add up to 100 , because some trials ended in hung juries. My figures for 1880 represent only the October session of the cour, and those for 1890 only the February session.

651. See supra Table 10 and accompanying text.

652. See FRIEDMAN \& PERCIVAL, supra note 135 , at 43 . Betwoen 1880 and 1910 , only about eight percent of cases began by way of indictment by a grand jury. See id. at $43-44$.

653. See id. at 158. 
review the evidence before the prosecutor brought charges. Knowing that a judge who had limited incentives to plea bargain would have to approve any deal that involved reducing or selectively eliminating charges, the lawyers now could strike a different sort of deal: In exchange for the prosecutor's promise to press only certain charges at the preliminary hearing, the defendant would promise to plead guilty to the face of the complaint. Researchers in later times have seen a good deal of this sort of bargaining at preliminary hearings in some (though not all) California courts and in courts elsewhere. ${ }^{654}$

Another aspect of the penal code added force to this charge-bargaining technique. In 1872, the California legislature had enacted a harsh penalty scheme governing repeat offenders that sometimes imposed stiff mandatory-minimum terms. ${ }^{655}$ For example, if a person once convicted of a crime punishable by state-prison time was later convicted of an offense punishable by a term of more than five years, the law imposed a minimum ten-year sentence. ${ }^{656}$ And if a person once convicted of petty larceny was later convicted of any crime punishable by state-prison time, the law required the court to impose the maximum term for the new offense ${ }^{657}$ For many defendants caught in this law's grip, the prosecutor's promise at the preliminary hearing to forgo the prior offense allegation must have been more than enough to make a plea bargain seem worthwhile. ${ }^{658}$

Friedman and Percival's finding that after the 1880s a growing number of defendants pled guilty to the charged offense now seems natural. The introduction of preliminary hearings in 1880 gave prosecutors and defense lawyers a new forum for plea bargaining. The deals these lawyers struckthat the defendant would plead to the face of the complaint if the prosecutor brought only certain charges-appeared in court records as pleas to the crimes charged. As lawyers mastered and internalized this new chargebargaining technique, such pleas inevitably became more common. Here, again, is just another example of lawyers' making do with what they had in contriving a plea-bargaining regime. And so we see again that although the scenery in Alameda is quite unlike that in Middlesex, the principles of power and interest that drove plea bargaining's development appear-at this quick and distant glance - much the same.

654. See Mather, supra note 489 , at 50 (citing BurEaU of Criminal Statistics, Felony DEFENDANTS DISPOSED OF IN CALIFORNIA COURTS: REFERENCES TABLES (1970): LIEF $\mathrm{H}$. CARTER, THE LIMITS OF ORDER (1974)). Mather notes that at the time of her own study in the early 1970s, such deals were not common in Los Angeles. See id.

655. See CAL. PENAL CODE $\S \S 666,667$ (Bancroft \& Co. 1885); Ex parte Gutierrez, 45 Cal. $429,430(1873)$.

656. See CAL. PENAL CODE $\S 666(1)$.

657. See id. $\S 667(2)$.

658. Friedman and Percival make it clear that the prosecutor had the discretion to charge or not to charge prior offenses. See FrIEDMAN \& PERCIVAL, supra note 135, at 170. 


\section{New York}

For New York there is no equivalent of the full-length treatment of the operations of the local justice system that Friedman and Percival give to Alameda County. Instead we must work from the scattered bits of evidence that emerge from Raymond Moley's classic 1928 expose of the oncehidden world of plea bargaining ${ }^{659}$ and from Mike McConville and Chester Mirsky's fuller but still brief study. ${ }^{660}$ These works agree about two critical facts-the kind of plea bargaining that the authors observed in New York and the timing of its rise.

McConville and Mirsky, who focus exclusively on New York City courts, report that the most common form of plea bargaining in the midnineteenth century was charge bargaining. Of the guilty pleas they observed in an 1865 sample, seventy percent were to lesser offenses and only twentyeight percent to the face of the indictment. ${ }^{661}$ Moley reported that eightyfive percent of all guilty pleas in New York City in 1926 were to an offense other than that charged-though the proportion was considerably smaller in the rest of the state. ${ }^{662}$ These are extraordinary rates of charge bargaining. In Alameda, Friedman and Percival found that only forty-five percent of all guilty pleas in 1880-1889 were to lesser offenses and that the figure dropped to twenty-four percent in 1890-1899 and to a mere eleven percent in 1900-1910. ${ }^{663}$ My findings in Middlesex show that after the middle of the century, when charge bargaining in liquor cases became defunct, charge bargains never amounted to even nine percent of all guilty pleas in the courts of the middle tier ${ }^{664}$ Only in murder cases, in which the mandatory death penalty gave prosecutors the power to charge bargain effectively, did charge bargaining dominate, accounting for virtually all guilty pleas.

The second fact that stands out about guilty pleas in New York is how early the trend upward began. McConville and Mirsky report a negligible

659. See Moley, supra note 47.

660. See McConville \& Mirsky, supra note 243. The authors are in the process of expanding their research into a book-length study. See Letter from Chester L. Mirsky (Dec. 28, 1998) (on file with the author).

661. See McConville \& Mirsky, supra note 243, at 466. The authors do not repor the corresponding figures for other years.

662. See Moley, supra note 47, at 111. Moley's categories are "Guilty to offense charged" and "Guilty to other offense." Id. It is reasonable to suppose that "other offense" refers to a lesser offense. Moley did not clearly separate statistics for New York City from those for the rest of the state. See id. Under a column labeled "total for state," he noted that $58 \%$ of guilty pleas statewide were to an offense other than that charged. See id. New York City probably dominates this statistic, however, as in three other categories-." large upstate cities," "small cities," and "rural" - the proportion of guilty pleas made to an offense other than that charged was $32 \%, 27 \%$. and $22 \%$, respectively. See id.

663. See supra Table 10 and accompanying text.

664. The highest figure I found was a little over eight percent in 1859.

665. See supra notes $87-99$ and accompanying text. 
guilty-plea rate from 1800 until about 1830 and then a nearly steady rise to a high of seventy-five percent of all dispositions in 1890, the last year of their study ${ }^{666}$ Moley's figures commence only in 1839 , but they show that the guilty-plea rate already had begun to grow and that it passed seventyfive percent in New York City by 1879 and in rural counties by the late 1890 s. ${ }^{667}$

To explain both the type and the timing of New York plea bargaining, we are wise to look first at prosecutors. We saw in Middlesex County that charge bargaining is primarily a prosecutorial device. Only the rare noncompliance of a grand jury can limit the prosecutorial prerogative to seek certain charges, and only extraordinary legislative action-such as the 1852 Massachusetts ban on nol prosses in liquor cases and California's general nol pros ban of 1851 - can limit the prosecutorial prerogative to drop or reduce charges by means of the nol pros. Although neither Moley nor McConville and Mirsky provide information that would help us assess how busy New York prosecutors were, it seems plausible to assume that they were quite busy and, like Middlesex prosecutors, felt strong incentives to reduce their workloads. ${ }^{668}$ That charge bargains were more common in New York City than in the rest of the state and that the rise of guilty pleas was steeper in the City than in rural counties ${ }^{669}$ might suggest that Gotham prosecutors were busier than the rest.

The more difficult question is where New York prosecutors got the power to engage in such a far-ranging charge-bargaining practice. Recall that in Middlesex County, the power to charge bargain in liquor cases arose from the peculiar penalty scheme of the liquor-license law, which required the judge to impose a fixed fine - or a fine within narrowly fixed boundsfor each conviction and therefore enabled prosecutors to dictate the sentence by manipulating the charges. In the first three-quarters of the century, before the mounting pressures of their civil caseloads converted judges to the cause of plea bargaining, the prosecutors' unilateral power to control sentencing was essential to charge bargaining's success.

It appears that New York's unusual criminal code of 1829 conferred a similar power but in a more broad-based way. Before 1829, New York law established a comparatively clumsy and undifferentiated schedule of criminal penalties. Persons convicted "of any manner of rape, or of . . burglary; or of ... robb[ery]," forgery, or setting fire to a house or

666. See McConville \& Mirsky, supra note 243, at 466.

667. See Moley, supra note 47 , at 108.

668. McConville and Mirsky do report that the annual caseload of the Coun of General Sessions, New York City's major criminal court, increased from 268 indictments in 1839 to 1323 in 1865. See McConville \& Mirsky, supra note 243, at 463 . But they do not tell us about the size of the district attorney's staff and do not say whether prosecutors worked full- or part-time.

669 . See supra notes 662,667 and accompanying text. 
barn were "punished with imprisonment for life." 670 Persons convicted of any other felony above the grade of petty larceny were imprisoned for "any term not more than fourteen years." ${ }^{671}$

Various features of the 1829 code, ${ }^{672}$ which took effect just as the rate of guilty pleas in the state started steadily upward, ${ }^{673}$ gave prosecutors unusually broad power to charge bargain. The code divided several crimes into different "degrees" that carried corresponding punishments. For example, first-degree burglary called for a penalty of not less than ten years; second-degree burglary for not less than five or more than ten years; and third-degree burglary for not more than five years. ${ }^{674}$ Abundant case law made it clear that prosecutors could use multi-count indictments to charge several degrees of the same crime ${ }^{675}$-a device that gave them, like prosecutors of liquor-law violations in Massachusetts, the leverage to exact guilty pleas in exchange for selectively nol prossing separate counts of the indictment.

When the statute assigned a minimum term of imprisonment to the higher degrees of a crime-as it did for both first- and second-degree burglary; first-degree robbery; first- and second-degree forgery; first-, second-, and third-degree manslaughter; and first-, second-, and thirddegree arson ${ }^{676}$-it bestowed peculiar power on the prosecutor to bind the judge's hands in sentencing and hence to persuade defendants to plead guilty. A defendant charged with first-degree burglary who faced a minimum ten-year term in state prison might have leapt at the prosecutor's offer to plead guilty to third-degree burglary with its guaranteed five-year maximum. ${ }^{67}$ Likewise, a defendant charged with second-degree burglary

670. Act of Mar. 21, 1801, ch. 58, §2,1801 N.Y. Stat. 97, 97 (declaring the crimes punishable by death or imprisonment in the state prison). A penalty statute of 1813 left intact most of the scheme laid out in the 1801 law. See Act of Mar. 19. 1813, ch. 29. $§ 3.1813$ N.Y. Stat. 407. The 1813 law did complicate the penalties for arson. establishing death as the penalty for burning an inhabited dwelling house, see id. $\$ 3$, at 407 , and imprisonment for not more than fourteen years as the penalty for buming any other house. barn. public building. or mill, see id. $\$ 3$. at 407 . And it established differing penalties for several forms of forgery. See id. $\S 3$, al 408-09.

671. $\S 5,1813$ N.Y. Stat. at $409 ; \S 4,1801$ N.Y. Stat. at 97 . Both the 1801 and the 1813 penalty schemes called for life sentences for those convicted a second time of any felony above the grade of petty larceny. See $\S 5,1813$ N.Y. Stat. at $409 ; \S 4,1801$ N.Y. Stat. at 97.

672. See 2 N.Y. REV. STAT. pt. 4, ch. 1, tit. 3. \$1, at 655 (Packard \& Van Benthuysen 1829).

673. See supra notes 666-667 and accompanying text.

674. See 2 N.Y. REV. STAT. pt. 4, ch. 1, tit. 3. \$2l. at 669.

675. See People v. Adler, 35 N.E. 644, 644-46 (N.Y. 1893); Hawker v. People, 30 N.Y. 487. 489-90 (1878); People v. Rynders, 12 Wend. 425, 429-30 (N.Y. Sup. Ct. 1834); Kane v. People, 8 Wend. 203, 210-11 (N.Y. 1831).

676. See 2 N.Y. REV. STAT. pt. 4, ch. 1, tit. 1. §1, at 656; id. tit. 3, §9, at 668; id. $\$ 21$, at 669 ; id. $\$ 57$, at 678 ; id. $\$ 42$, at 675 ; id. $\$ 20$, at 662-63.

677. One hundred forty years later, when the head of a commission to draft a new penal code for New York was asked whether the need to facilitate plea bargaining had prompted the commission to split a raft of crimes into multiple degrees, he replied: “ Decidedly! We were very conscious of the negotiation process, and that's the reason for our extensive degree structure. ... [I]t's very important that one can take the negotiating process right down the line through the 
who faced a minimum five-year term might readily have pled guilty to attempted second-degree burglary, with its maximum five-year term. ${ }^{678}$ McConville and Mirsky report that of the seventy-three guilty pleas to lesser offenses that they observed in an 1865 sample, thirty-four-or fortyseven percent-involved reducing the charged offense to a mere attempt. ${ }^{679}$ The Massachusetts penal code simply denied prosecutors the power to engage in such broad-based charge bargaining. Of all the commonly prosecuted crimes, only liquor-law violations, murder, and a few other very serious offenses that called for mandatory life imprisonment or mandatory death carried minimum penalties. And not until 1974 did the Supreme Judicial Court deem attempt to be a lesser-included offense of the substantive charge. ${ }^{680} \mathrm{I}$ did not observe a single nineteenth-century case in which the defendant pled guilty to attempt as part of a charge bargain.

An additional source of charge bargaining power in the 1829 code was its harsh treatment of two broad categories of second offenders, whom it exposed to substantial minimum penalties. ${ }^{681}$ These provisions precisely tracked - and therefore must have inspired-the 1872 second-offender laws in California that I discussed earlier. ${ }^{622}$ As in California, these mandatory penalties put the prosecutor in a position to threaten the defendant with a long prison term that the judge had no power to avoid. But unlike California prosecutors, who had no power to nol pros prior offense allegations and had to wait for the institution of preliminary hearings in 1880 to find a forum for plea bargaining, New York prosecutors could wipe out the prior offense allegation in exchange for the defendant's guilty plea to the present charge. In Massachusetts there was no broad-based law that heightened the penalty for second offenses, and not until 1887 did the state enact severe minimum penalties for third offenders. ${ }^{683}$ Before then, the only similar law I have seen

degrees." Drafting a New Penal Law in New York: An Interview with Richard Denzer, 18 BUFF. L. REV. 251, 258 (1969).

678. See 2 N.Y. REV. STAT. pt. 4 , ch. 1 , tit. $3, \S 21$, at 669 ; id. tit. $7, \S 3(2)$, at 698 .

679. See McConville \& Mirsky, supra note 243, at 466-67.

680. See Commonwealth v. Gosselin, 309 N.E.2d 884, 887-88 (Mass. 1974) (relying on holdings of courts of other states and on analogous Massachusetts cases).

681. The first of these provisions imposed a minimum 10-year term on any person who, having been convicted in the past of a crime punishable by prison time, was later convicted of a crime punishable by more than five years in state prison. See 2 N.Y. REV. STAT. pt. 4, ch. 1, tit. 7. $\S 8(1)$, at 699 . The second provided that any person who once was convicted of either petty larceny or an attempt to commit any crime punishable by state prison and who then was convicted of any crime punishable by a term in state prison less than life "shall be sentenced to imprisonment in such prison, for the longest term prescribed" by statute. $I d$. $\S 9(2)$, at $699-700$. The reference to those once convicted of an attempt is particularly significant in light of the use prosecutors made of attempt convictions in the course of charge bargaining.

682. See supra notes 655-657 and accompanying text.

683. A habitual-offender law of that year imposed a 25-year term for offenders who twice previously served prison terms of three or more years. See Act of June 16, 1887, ch. 435, $\S 1$, 1887 Mass. Acts 1098, 1098. In 1890, one of the proponents of the law complained that prosecutors had used it only three times. See Twenty-Years' Sentence, BOSTON EVENING TRANSCRIPT, Jan. 18, 1890, at 9 (letter of Clement K. Fay). 
in use, outside the context of the liquor laws, imposed a rather mild minimum three-year term on those convicted a second time of theft.tss

The power of New York prosecutors to enter nol prosses leads us to the one real mystery surrounding the state's vigorous charge-bargaining practice. The penal code of 1829 said nothing of the nol pros power. In 1836 , however, the legislature stripped the state's district attorneys of the power "to enter a nolle prosequi upon any indictment, or in any other way to discontinue or abandon the same, without the leave of the court having jurisdiction to try the offence charged." ${ }^{685}$ I have not been able to trace the legislature's motivations in making this change and have found but a single, cryptic clue to the law's purpose in an 1841 opinion of the state supreme court, then an intermediate appellate court. In People v. McLeod, ${ }^{656}$ the court pointed out that the state's attorney general and its several district attorneys formerly shared the nol pros power and that the legislature had chosen to leave the attorney general's power unimpaired even as it withdrew power from the district attorneys. Apparently, the court surmised, the legislature had found the nol pros power in too "many hands, and fear[ed] its abuse." ${ }^{687}$ What sort of abuse the court did not say. It is fair to infer that the legislature would not have acted had district attomeys not made frequent use of nol prosses-a phenomenon that would square with McConville and Mirsky's and Moley's figures showing a strong increase in the rate of guilty pleas beginning by the late $1830 \mathrm{~s} .{ }^{688}$

It is harder to explain why the 1836 law did not hait the apparent progress of charge bargaining in New York. After all, when the Massachusetts legislature imposed a similar restriction on prosecutors' use of nol prosses in liquor cases in 1852, prosecutorial charge bargaining in these cases came to an abrupt stop. ${ }^{689}$ The most likely explanation for the New York law's failure to squelch charge bargaining is that the law did not by its terms forbid the practice. A charge bargain did not require the prosecutor "to enter a nolle prosequi upon [the] indictment," or "to discontinue or abandon the same," but merely to nol pros one count of the indictment-hence the usefulness of the multi-count charging practice I noted earlier. Given that the nol pros power traditionally had lain with the

684. See Act of Mar. 16, 1805, ch. 143, \& 3, 1804 Mass. Acts 240, $241-42$

685. 2 N.Y. REV. STAT. pt. 4, ch. 2 , tit. 4, $\$ 54$, at 609 . The cited section seems to have been adopted as part of the statutory revision of 1836. I have not found any session law between 1829 and 1836 that prescribes this change.

686. 1 Hill 377 (N.Y. Sup. Ct. 1841).

687. Id. at 405 .

688. See McConville \& Mirsky, supra note 243, at 466 fig.3: Moley, supra note 47, at 108. Moley's chart presents data for 1839 and later. The rate of guilty pleas seems already to be increasing as of 1839. See Moley, supra note 47, at 108.

689. See supra notes 173-179 and accompanying text. 
prosecutor, trial courts may have been reluctant to deprive him of that power absent a more precise legislative command.

Alternatively, one could surmise that the 1836 law failed to slow charge bargaining because New York judges, unlike those in Massachusetts, readily gave their consent to the necessary nol prosses. The course of later legislation in New York, however, suggests that judges remained unfriendly toward prosecutorial charge bargaining for some time to come. When David Dudley Field, David Graham, and Arphaxed Loomis reported a code of criminal procedure to the New York legislature in $1849,{ }^{690}$ they proposed to abolish the noi pros altogether. The Graham Code (as it came to be known) flatly declared that "neither the attorney general, nor the di[s]trict attorney shall hereafter discontinue or abandon a prosecution" ${ }^{691}$ and instead bestowed on judges an exclusive power to dismiss criminal actions either "of [their] own motion, or upon the application of the district attorney." 692

The authors at first gave no reason for proposing a wholesale shift of the power to terminate prosecutions. They claimed simply that several components of their code, including this one, "are sufficiently explained by the provisions themselves." ${ }^{693}$ But in a revision of the proposed code submitted the following year, they suggested that the court's 1841 ruling in McLeod had prompted their action. The court had held that the nol pros law of 1836 , which by its terms gave trial courts the power to veto prosecutorial nol prosses, gave them no power to enter a nol pros "unless by consent or on motion of the district attorney." ${ }^{694}$ The code's authors argued that the court thereby had made "the power of the district attorney, in this respect, ... greater than that of the court." ${ }^{695}$ Far better, they wrote, that the nol pros power rest "where it should alone rest, in the hands of the court." ${ }^{696}$ The authors never explained why, if they sought merely to remedy the inability of judges to end criminal prosecutions on their own motion, they proposed to take all such power from prosecutors. Nonetheless, we may infer two things from their proposal: First, they believed that the 1836 law had not sufficiently restricted district attorneys'

690. See 4 REPORT OF THE COMMISSIONERS ON PRACTICE AND PLEADINGS: CODE OF CRIMINAL PROCEDURE (Albany, Weed, Parsons \& Co. 1849) [hereinafter FOURTH REPOrt of THE COMMISSIONERS]. The proposed code of criminal procedure apparently was primarily Graham's work and became known as the Graham Code. See People v. Willis, 52 N.Y.S. 808. 809 (Sup. Ct. 1898).

691. FOURTH REPORT OF THE COMMISSIONERS, supra note 690, § 754, at 196.

692. Id. \& 753, at 196.

693. Id. at lxix.

694. THE CODE OF CRIMINAL PROCEDURE OF THE STATE OF NEW-YORK: REPORTED COMPLETE BY THE COMMISSIONERS ON PRACTICE AND PLEADINGS 343 (Albany, Weed, Parsons $\&$ Co. 1850) [hereinafter CODE OF CRIMINAL PROCEDURE].

695. Id.; see also People v. McLeod, 1 Hill 377, 405-06 (N.Y. Sup. Ct. 1841) (announcing the holding to which the code authors referred).

696. CODE OF CRIMINAL PROCEDURE, supra note 694, at 343. 
nol pros power. Second, they did not believe judges had connived in whatever abuses district attomeys had wrought with that power-for if they had suspected judicial complicity, they surely would not have handed all power to judges.

This complete ban on prosecutorial nol prosses did not become law for some time, and in the meantime, by whatever mechanism, prosecutors appear to have retained their nol pros power despite the 1836 ban. In 1869 , the New York Times printed a front-page discourse on the ills of the state's criminal justice system. While pointing out the dangerous concentration of power in the prosecutor, the anonymous but seemingly well-informed author claimed that the prosecutor "can without question enter a nolle prosequi in any case where an indictment has been found." 697 "He may go further and accept a plea from a prisoner guilty of an offence many degrees lower in grade than that charged in the indictment by the Grand Jury." 698 Where the prosecutor got these powers the author did not say. At about the same time, though, a somewhat jaded observer commented that a district attorney's "motion for leave to enter a nolle prosequi is granted by courts almost invariably, their assent being well nigh a matter of form." 999 of course, by this time, or not long afterward, Massachusetts judges as well had begun to soften their resistance to plea bargaining.

In any event, between 1850 and 1880, as the Graham Code languished unenacted, the proportion of cases ending in guilty pleas reached and surpassed seventy-five percent. ${ }^{700}$ Most of these pleas took the form of charge bargains. ${ }^{701}$ In 1881 , the legislature finally put in force the entire proposed code, including the nol pros ban. ${ }^{702}$ Whether it gave any attention to the parts of the code that concern us now, which were only two provisions in a code that contained hundreds, is not clear. What is both clear and unsurprising is that if the legislature had intended to end charge bargaining in New York by depriving prosecutors of the power to enter nol prosses, it failed in its mission. Moley's figures show that the rate of guilty pleas in New York City, where charge bargains were most common, ${ }^{703}$ dipped barely perceptibly after enactment of the code and then climbed to a new high. ${ }^{704}$ That this result is unsurprising is a consequence of what

697. Concerning Crime, N.Y. TIMES, Feb. 12, 1869, at 1. Alexis Haller, one of my research assistants, found this important evidence.

698. Id.

699. TWENTY-FIRST ANNUAL REPORT OF THE PRISON ASSOCLATION OF NEW YORK. reprinted in ASSEMBLY DOC. NO. 50, at 134 (N.Y. 1866).

700. See Moley, supra note 47 , at 108.

701. See supra notes 661-662 and accompanying text.

702. The legislature made only minor modifications to the Graham Code which are not important here. See Act of June 14, 1881, ch. 504, $\$ 671-672,1881$ N.Y. Laws 164, 164-65: People v. Willis, 52 N.Y.S. 808,809 (Sup. Ct. 1898).

703. See supra note 662 and accompanying text.

704. See Moley, supra note 47 , at 108. 
Middlesex County's history has taught: By 1881 , judges were confronting an onslaught of new civil litigation. No doubt New York judges, like their Massachusetts counterparts, abandoned whatever antipathy they once might have borne toward prosecutorial charge bargaining and lent it what aid they could. As Moley observed in 1926, New York judges dismissed cases about as often as prosecutors in other states entered nol prosses. "The practice [of nol prossing] exists," he wrote, "although the name is gone." 705

In New York, then, as in California and England, the principles that emerged from our study of Middlesex County go far toward explaining the course of plea bargaining's rise. If plea bargaining in New York more often took the form of prosecutorial charge bargaining than did plea bargaining in California or Massachusetts, it is because New York law gave prosecutors more leverage to manipulate sentences by manipulating charges than did California or Massachusetts law. And if plea bargaining got an earlier start in New York than in California or Massachusetts, it is in part because the legal framework to support prosecutorial charge bargaining was in place by 1829 and in part because the frenzy of life in the Metropolis perhaps taxed prosecutorial resources more heavily than did the relative quietude of California or even Middlesex County.

\section{The Power of Plea Bargaining}

We have seen that both within and outside Massachusetts, we can explain a good deal of plea bargaining's progress by asking who held the power to bargain and who had the incentive. Now we can move ahead to explore the broader consequences of plea bargaining's amassed power. By "plea bargaining's power," I mean of course its derived power, for the power of plea bargaining is the power of the courtier-the influence it has gained by serving well the interests of those in high places. I will begin, therefore, by sorting the several ways plea bargaining has served the interests of those who hold power in the criminal courtroom. I will then consider how plea bargaining's amassed power has helped or hindered the progress of other institutions of criminal justice.

\section{A. The Sources of Plea Bargaining's Power}

We have seen already that one of plea bargaining's great attractions for prosecutors and judges was its efficiency. When Middlesex prosecutors of the 1840s found themselves staggering under rapidly growing caseloads, they multiplied charge bargains in liquor cases and employed on-file plea bargains in a whole range of cases. And when Massachusetts judges of the

705. Id. at 101. 
last quarter of the century faced hugely increasing demands from their civil calendars, they threw their considerable power behind the cause of plea bargaining by engaging in sentence bargaining on an ever greater scale. The sheer efficiency of plea bargaining as a means of clearing cases to some extent has frozen it in place. When prosecutors and judges manage to keep pace with fast-growing workloads either with no increase in staffing or with increases that lag behind the growth in case numbers, any appeal they might make to the legislature for more personnel will fall short.

But the efficiency of plea bargaining is not the only benefit it extends to power-holders. It is obvious that prosecutors like plea bargaining because it secures victory in the case. What is less obvious is that plea bargaining confers almost the same advantage on judges. True, most judges have no personal or professional stake in seeing the defendant convicted, but a plea bargain still means that the judge "wins" to the extent that it guards against the reputational blow of a reversal: Without a trial, after all, the judge cannot commit a trial error ${ }^{706}$ It is not clear when trial judges first began to regard reversals with dread and therefore to view this aspect of plea bargaining as a virtue. Massachusetts district attorneys first had to report their win/loss statistics to the attorney general in the 1830s, and at least one district attorney made a point of bragging about his conviction rate as early as $1844{ }^{707}$ What evidence I have of judicial concern for reversal rates arises later and hence accords with other evidence that judges came around to the cause of plea bargaining only decades after prosecutors had put in place the equipment of charge bargaining in liquor and murder cases.

It is no surprise that judges of the first half of the nineteenth century did not concern themselves much with reversal rates-there simply were too few appeals. Theodore Ferdinand reports that between 1814 and 1822, defendants appealed in only three percent of municipal-court cases in Boston, a figure that declined through the first half of the century to just over one percent between 1844 and $1850 .^{703}$ By the end of the century, however, the pace of appeals was growing. According to one study, criminal appeals in Massachusetts increased from about 2200 in the early 1890 s to about 3500 in 1900 -with larger increases to follow. ${ }^{709}$ In California at about the same time, Friedman and Percival saw only slight growth in the overall frequency of appeals, which generally occurred in about two or three percent of all cases, but at times reached as high as six

706. Friedman and Percival break down the grounds for appeal of Alamedn County cases between 1870 and 1910 . Two-thirds of claimed errors can be traced to judicial rulings on evidence or law or to the judge's jury instructions. See FrIEDMAN \& PERCIVAL, supra note 135, at 265 tbi.8.4.

707. See supra note 285 and accompanying text.

708. See FERDINAND, supra note 121, at 128, 130.

709. See Wilfred Bolster, Criminal Appeals, MASS. L.Q., Aug. 1922, at 16, 16a [i.e., unnumbered page opposite page 16]. 
percent. ${ }^{710}$ But when they measured appeals as a proportion of convictions after trial, rather than as a proportion of all cases, Friedman and Percival found that appeals more than doubled from $8.4 \%$ in the 1880 s to $17.7 \%$ in the 1890 s and fell off only slightly between 1900 and $1910 .^{711}$

One can find occasional anecdotal evidence of trial judges' concern with the possibility of reversal on appeal. In 1879, for example, the Michigan Supreme Court reviewed the actions of a trial judge who had coerced a plea bargain apparently to avoid the risk of appeal. As the high court recounted the case, after the judge had rejected the defendant's pretrial motion to dismiss and the jury had returned a guilty verdict, "[s]ome very extraordinary proceedings followed. The defendant was given by the judge to understand that he must submit to a severe sentence or else withdraw his plea of not guilty, enter a plea of guilty and immediately pay $\$ 400$ and estop himself from bringing error." 712 But the earliest evidence that I have found of a more generalized desire among judges to avoid the risk of reversal dates to the 1920s. A Massachusetts district attorney wrote in 1926 of trial judges' "[f]ear of reversal," though he drew no connection between that fear and judges' attitudes toward plea bargaining. ${ }^{713}$ It was left to Raymond Moley to make this connection in his 1928 indictment of the newly "discovered" practice of plea bargaining: The prosecutor "does not run the risk of losing" when the case ends in a plea bargain, he wrote, and "the judge escapes the danger of being reversed on some point of law."714

As the twentieth century wore on and expanding procedural protections generated more criminal appeals, ${ }^{715}$ three sets of actors felt the growing

710. See FriEdman \& PERCIVAL, supra note 135 , at 262 tbl.8.2.

711. See id.

712. O'Hara v. People, 3 N.W. 161, 161 (Mich. 1879) (emphasis added). The only similar case I have seen arose in the Lowell, Massachusetts, police court in 1841. Catherine Fitzgerald. charged with liquor-selling, objected that she could not be held responsible for a misdemeanor committed in her husband's presence. "Of this His Honor was not quite certain," the Lowell Courier reported, "but would not pass sentence till she would agree not to appeal . . . but would hold her to answer further, and her liege lord also. Kate paid the fine, rather than her 'man' should go to the Grand Jury ...." Lowell Police Court, LOwELl COURIER, May 11. 1841, at 2. That is. the magistrate gave the defendant the option of paying a fine on the charged offense and forgoing her right to appeal or being bound over together with her husband to face higher charges before a grand jury. True, this was a proceeding in police court, and the defendant's appeal right consisted of a de novo proceeding in superior court rather than an appeal on questions of law. But as the magistrate apparently was worried that a higher tribunal would spy his mistake on a legal question, this case perhaps is an example of judges' general aversion to reversals.

713. Thomas C. O'Brien, Crime and Criminal Law, MASS. L.Q., May 1926, at 33. 34 (" Fcar of reversal in the Supreme Court compels trial judges to resolve doubtful questions as to the admission of testimony and instructions to the jury in favor of the defendant, for the Government has no right of appeal.").

714. Moley, supra note 47 , at 103.

715. See Alschuler, supra note 2, at 38-39. The defendants' new procedural protections fall into two categories: those that expanded the substantive rights that may become the basis for appeal, including cases that required state courts to exclude illegally seized evidence; and those that directly expanded the opportunity for appeal by guaranteeing indigent defendants appellate counsel. See id. at 39. 
allure of plea bargaining. For prosecutors, more appeals inevitably meant both more time-consuming prosecutions and more reversals on appeal, and so the usefulness of plea bargaining both to secure efficient dispositions and to assure victory in the case grew larger.$^{716}$ As trial judges saw the greater potential for reversals and the reputational damage that they brought, personal interests bound them ever tighter to plea bargaining's cause. And as appellate judges suffered under the weight of their growing dockets, they too began to know the efficient promise of plea bargaining. It is little wonder, perhaps, that the United States Supreme Court's definitive affirmation of the legality of plea bargaining-rendered as though "any other course would be unthinkable" "717-came amid a period of overwhelming growth of criminal appeals in the federal courts. ${ }^{718}$

The pressure of criminal appeals on appellate judges, like the pressure of criminal trials on trial judges, is to some extent a function of the judges' civil workloads. In Part V, I argued that the civil-litigation revolution of the late nineteenth century had confronted trial judges not only with more civil trials, but with a more complex brand of negligence trials that absorbed far more time than the old nonpayment disputes that had typified their civil docket. $^{719}$ Likewise, appeals in negligence cases, as Roscoe Pound recognized in 1939, "require an exceptionally critical consideration of details of evidence in voluminous records." ${ }^{720}$ The nature of today's civil appellate caseload, then, creates even greater incentives to limit the criminal appellate caseload.

At least three influential participants in the criminal justice systemprosecutor, trial judge, and appellate judge-therefore see plea bargaining as a means toward efficient management of overgrown workloads. At least two-prosecutor and trial judge-see it as a means to guard their reputations from the scent of fecklessness or incompetence. And criminal defendants, lest we forget them, may see plea bargaining as a means to avoid uncertainty and to elude the most severe allowable sentence. But beyond these advantages that plea bargaining confers on individual participants in the justice system, it confers another on the system as a

716. See id. at 38-39 ("By increasing the likelihood of appeal. these decisions Igranting defendants greater procedural protections] encouraged prosecutors to magnify the concessions granted to defendants in exchange for guilty pleas that would effectively foreclose appellate review of most issues.").

717. Id. at 40 .

718. The most important of the Supreme Cour's early decisions on plea bargaining appeared in 1970 and 1971. See Santobello v. New York, 404 U.S. 257 (1971); North Carolina v. Alford, 400 U.S. 25 (1970); Parker v. North Carolina, 397 U.S. 790 (1970); McMann v. Richardson, 397 U.S. 759 (1970); Brady v. United States, 397 U.S. 742 (1970). Between 1960 and 1980, the number of appeals filed in federal courts of appeal almost quintupled-with criminal appeals rising faster than civil appeals-while the number of judges merely doubled. See Galanter, supra note 536 , at 38 .

719. See supra notes 540-541 and accompanying text.

720. Roscoe Pound, The Judicial Office Today, 25 A.B.A. J. 731.732 (1939). 
whole: To the extent that a plea bargain delivers a verdict that onlookers acknowledge to be truthful, ${ }^{721}$ it protects the jury and the system that sponsors it from the risk of issuing the wrong verdict-or to be precise, a verdict the public will perceive to be wrong. That is, despite all the criticism heaped upon plea bargaining by those who think that it deprives defendants of their trial right or the public of its right to uncompromised punishment, when it comes to the apparent accuracy of outcomes, plea bargaining helps protect the system's legitimacy. ${ }^{722}$

In fact, plea bargaining may do an even better job of protecting the system from the perception of wrongful verdicts than at first appears. Harry Kalven and Hans Zeisel concluded in their monumental study, The American Jury, that plea bargaining tends to remove from the jury system those cases in which the defendant faces the clearest evidence of guilt:

If all controversies of criminal law were placed on a continuum from the weakest to the strongest in terms of the prosecution's case, the guilty plea... would be likely to withdraw cases from the strong side of the continuum, leaving the weaker cases for jury trial.

The upshot is that, out of the great universe of criminal controversies, those surviving to jury trial ... are likely to be the more controversial cases where, in the nature of things, the chances of disagreement are increased. ${ }^{723}$

As we might expect, when defendants regard their odds of conviction to be all but certain, they are more likely to seek a deal to cut their losses. If they sense freedom within their grasp, they are more likely to insist on trial. ${ }^{724}$ Hence "the higher the chances for acquittal, the less likely the guilty plea, and vice versa." 725

The usefulness of this division of labor between plea bargaining and jury trial, in which the bargaining process handles the easy cases and the jury the hard ones, becomes clear when we reflect on the consequences of the jury's returning a "wrong" verdict in a "clear" case. The system's legitimacy suffers its greatest strain when the public feels sure that the jury

721. Of course, an Alford plea, in which the defendant adheres to her claim of innocence even while allowing that the government has enough evidence to prove her guilt beyond a reasonable doubt, see Alford, 400 U.S. at 38, does not meet this condition. But Alford pleas represent a tiny proportion of all plea bargains.

722. By the system's "legitimacy," I mean the public's perception that the system is, on the whole, doing justice.

723. KALVEN \& ZEISEL, supra note 460, at 30-31; see also id. at 20-22 (presenting data to support the quoted conclusions).

724. See id. at 21-22.

725. Id. at 21 . 
has erred ${ }^{726}$ But because defendants who face overwhelming evidence of guilt typically bargain for the best deal they can get, the jury rarely faces a clear case and rarely risks being clearly wrong. Instead, as Kalven and Zeisel said, the jury gets "the more controversial cases where, in the nature of things, the chances of disagreement are increased." 727 These are the cases that the jury cannot as easily get "wrong." Even if the jury convicts the innocent or acquits the guilty, the uncertainty of the evidence will help keep the public from seeing the error. Precisely because these cases are controversial, and precisely because they present a greater chance of disagreement, the jury's verdict can settle all controversy and resolve all disagreement.

Plea bargaining and jury trial, then, have joined in a task of erasing all apparent error from the criminal justice system. Little clear error can escape from the black box of the jury's deliberation room as long as only controversial cases enter. And plea bargaining by its very nature hides both factual and legal error: By admitting guilt, the defendant eliminates any formal doubt of guilt. By renouncing trial and all right to complain of pretrial error, the defendant normally bars any court from declaring error on appeal. We should not wonder at the staying power of plea bargaining. Not only does it ease the workloads and protect the reputations of the two most powerful courtroom actors-judge and prosecutor-it also protects the reputation of the system as a whole.

726. The two clearest examples of this phenomenon in recent American history are the first Rodney King trial and the O.J. Simpson criminal trial. In the King case, videotape captured the defendant police officers as they beat a handcuffed King with clubs. In the Simpson case, a tight web of circumstantial evidence, including DNA tests, bound the defendant to the crime. In each, the jury's acquittal prompted broad (though not universal) public indignation and demands for systemic reform. In both instances, however, the failure was not merely with the jury system. but also with the plea-bargaining system. In most normal cases that presented such overwhelming evidence of guilt, defendants would have cut their losses by striking the best deal available. The sheer celebrity of these prosecutions made such a result politically impractical. The officers' actions in the King case so outraged the public, and paricularly the African-American community, that any perceived compromise by the prosecution would have invited a firestorm. Nor could the Los Angeles district attorney, who would soon face a reelection battle, have shown weakness in the Simpson case, in which his deputies claimed to have a "mountain of evidence." David Margolick, Judge Ito To Open Files on 10 Dismissed Jurors, N.Y. TMES, June 24, 1995, at 6 (quoting deputy prosecutor Lisa Kahn). True, one of Simpson's defense lawyers later said that the district attorney did offer a deal, see JOHNNIE L. COCHRAN, JR. WITH TAM RUTTEN, JOURNEY TO JUSTICE 253 (1996), but the district attomey denied the claim, see Randall Kennedy, Ploying to the Crowd: Journey to Justice, L.A. TMMES, Oct. 13, 1996, at 4 (reviewing COCHRAN wTtH RUTTEN, supra). Only because the plea-bargaining system failed did these cases go to trial. And only for that reason was the system exposed to humiliation when the juries got such clear cases "wrong."

It is true that by withdrawing easy cases from the jury's consideration, plea bargaining (when working normally) both protects the jury from getting a clear case wrong and deprives it of the chance to get a clear case right. My argument assumes what to me (but perhaps not others) seems obvious: that the damage done to the jury's legitimacy when it delivers a clearly mistaken verdict overwhelms the legitimacy benefits of getting an easy case (or even many casy cases) right.

727. KALVEN \& ZEISEL, supra note 460 , at 31 . 


\section{B. The Consequences of Plea Bargaining's Power}

Plea bargaining has used its enormous power, gained by promoting the interests of power, to help or hinder those procedural institutions that help or hinder plea bargaining. Here I return to the image of plea bargaining as a courtier. Though plea bargaining has no power of its own, the judges and prosecutors who dictate what goes on in our criminal courtrooms do have power-and they have strong interests in seeing plea bargaining thrive. I do not suggest that they act in concert or even that they always know the consequences of their actions, but only that they try to make plea bargains happen. And in so doing, they raise up those procedural institutions that help plea bargaining thrive and beat down those that threaten it.

I argued in Part III that the steady and vigorous growth of probation was one consequence of this derivative power of plea bargaining. Probation stands as an especially clear case of the symbiosis that can develop between plea bargaining and a friendly procedural innovation: Because prosecutors who sought a new method of plea bargaining made use of the same procedural device that later took the name of probation, plea bargaining helped invent probation. In the case of the two procedural innovations that I take up now-indeterminate sentencing and public defenders ${ }^{728}$ - the formative influence of plea bargaining has been less direct. One can assign various causes for the failure of the indeterminate sentence, which arose with apparent promise at the close of the nineteenth century. But a good deal of the evidence surrounding its demise traces to plea bargaining's door, and the supporters of plea bargaining indeed had a motive to wish the downfall of the indeterminate sentence. That is, those judges and prosecutors who found benefits in plea bargaining had reason to shun the indeterminate sentence and to limit its growth. There are also various ways to explain the introduction and success of organizations for the defense of the poor. Still, the evidence seems clear that public defenders emerged at least in part because they promised to ease the course of plea bargains. We therefore must examine the possibility that they have thrived in part because they fulfilled that promise.

\section{The Indeterminate Sentence}

When examining the interplay between the indeterminate-sentencing movement and the plea-bargaining system, we have to separate the principles of the indeterminate sentence from its reality. Its principles, as I

728. Not all lawyers for poor defendants were "public" defenders when these officials first appeared in the early 20 th century. I use the term because it is more familiar to modern cars than the arguably more accurate "institutional defenders." 
argued in Part V, perhaps actually aided plea bargaining. By suggesting that punishment should look forward and not backward, advocates of the indeterminate sentence relieved judges of the strict obligation to learn all they could about the defendant's past crime before imposing sentence-an obligation that they once had met by hearing evidence at trial. Moreover, the belief that, because judges could not predict when a convict would be reformed, prison and parole authorities should decide the actual release date meant that judges did not have to struggle to get the defendant's sentence exactly right. If the rough-and-tumble of the bargaining process produced a sentence that was other than ideal, prison and parole authorities could tailor it to fit more suitably.

The reality of the indeterminate sentence, however, if ever enacted according to the highest ideals of its advocates, would have shrunk plea bargaining to insignificance. The purest adherents of the indeterminate sentence thought that its indeterminacy should be complete. Once the judge sentenced the defendant to incarceration, prison and parole authorities would release him when he had "reformed," neither earlier nor later, with no constraint imposed either by judge or by statute. ${ }^{729}$ Even in such a system, some amount of plea bargaining might have persisted as defendants offered to plead guilty to secure probation rather than indeterminate incarceration. But those defendants whose crimes demanded that they serve time would have had no incentive to plead, because both judges and prosecutors would have lacked the power to promise a shorter term.

It is probably significant, then, that no state ever enacted a true indeterminate sentence. ${ }^{730}$ At the very least, "indeterminate" sentencing laws imposed a statutory maximum on the length of incarceration, so that even an unreformed inmate at some point had to go free. The Massachusetts indeterminate-sentencing law of 1886 , the nation's second, provided that

729. See, e.g., Samuel J. Barrows, Introduction to THE INDETERMINATE SENTENCE AND THE PAROLE LAW, supra note 562, at 5 ("The value of the indeterminate sentence as a protection to society lies in the fact that the prisoner is not released until it is deemed safe to discharge him."); Seth Cooley Cary, Prison Reform-The Indeterminate Sentence, 8 ALPHA 1. 2 (1889-1890) (" [1]f it be right to restrain one class [such as the idiotic or insane] so long as the disability continues, it must also be legitimate to restrain all dangerous classes while the disability remains. Therefore, it is the right and also the duty of the State to confine the criminal so long as he remains vicious."): Lewis, supra note 562, at 17 (maintaining that "the principle of what is inexactly called the indeterminate sentence" is that "no man be imprisoned unless it is clear that his freedom is dangerous to others, and that, when once imprisoned, no man be freed until the danger has ceased").

730. See, e.g., WILCOX, supra note 563, at 11 (“' (A]n absolutely indeterminate sentence... has never anywhere been enacted into law."); Report of the Committee of the American Bar Association, in THE INDETERMINATE SENTENCE AND THE PAROLE LAW, supra note 562, at 24, 26 ("Strictly speaking, the right to impose [indeterminate] sentences does not exist in any State. Statutes permitting what are commonly called indeterminate sentences are such only in degrec."): Legislation-Indeterminate Sentence Laws-The Adolescence of Penocorrectional Legislation. 50 HARV. L. REV. 677, 678 (1937) ("The titles of [today's indeterminate sentence laws] are somewhat misleading because none of them provides for a truly indefinite sentence."). 
inmates convicted of certain less serious crimes must go free within two years and all others within five years unless the sentencing judge specified a longer term. ${ }^{731}$ Even such imperfect indeterminate-sentencing provisions could have hobbled plea bargaining because they took a great deal of the power to dictate the length of sentence from judges' hands. But another, more substantial departure from complete indeterminate sentencing left largely intact judges' power to promise shorter sentences to defendants who pled guilty: Those states that enacted indeterminate sentencing (of the imperfect sort just mentioned) ${ }^{732}$ simply made it an additional sentencing option. Some states explicitly gave judges the choice to impose an indeterminate sentence or not, as they pleased. Others required sentences to certain institutions to be indeterminate, but imposed no such requirement on sentences to other institutions.

The 1886 Massachusetts law, for example, provided in seemingly mandatory terms that " $[w]$ hen a convict is sentenced to the Massachusetts reformatory, the court or trial justice imposing the sentence shall not fix or limit the duration thereof." ${ }^{733}$ But the law by no means required judges to send convicts to the reformatory instead of the state prison or county house of correction or any one of several other possible places of confinement. In 1890, in an editorial titled "Indefinite Commitments," the Boston Evening Transcript complained that " [s]ome change in the right direction was made by the legislature of four years ago, but the law has not accomplished what was hoped. It is said that the reform has not been carried out by the judges to the full extent which it was expected...." ${ }^{734}$ The paper was right to claim that judges did not often make use of the indeterminate sentence. The records of the Middlesex Superior Court show that in 1890, judges chose the reformatory for barely ten percent of convicts who served time-a figure that rose to twenty-two percent in 1896 before falling back to eighteen percent in 1900 and only twelve percent in $1910 .^{735}$ These numbers

731. See Act of June 24,1886 , ch. 323, §§ 1-3, 1886 Mass. Acts 296, 296. New York's indeterminate sentencing law of 1877 was the nation's first substantial experiment with the concept, though Michigan had attempted a small-scale experiment in 1869. See Act of Apr. 3 . 1869, No. 145, $\$$ 4-5, 1869 Mich. Acts 264, 265-66 (providing that convicted adult prostitutes shall be punished by three years' imprisonment, but that they may be released "upon reformation. or marked good behavior" by the inspectors of the house of correction); infra note 736 .

732. To avoid this parenthetical in the future, and to avoid always putting "indeterminate sentence" in quotes, I will simply use the term indeterminate sentence with the understood qualification that there was no such thing in its pure form in American law.

733. $\S 1,1886$ Mass. Acts at 296.

734. Indefinite Commitments, BOSTON EVENING TRANSCRIPT, Jan. 30, 1890, at 4.

735. In 1898, the legislature extended the reformatory's indeterminate-sentencing structure to the Bridgewater State Farm. See Act of May 20, 1898, ch. 443, $\$ 1,1898$ Mass. Acts 395. 395. In 1900 , the state farm accounted for an additional six percent of all incarcerations and in 1910 for an additional $10 \%$. As virtually every sentence I saw to the state farm was for drunkenness. defendants sent there perhaps fell into a special class. Judges may have seen more sense in the ideal of the indeterminate sentence when the point of confinement was to cure the convict of an addiction. 
are perhaps especially low given that the state reformatory was conveniently nearby -in Concord, at the heart of Middlesex County.

Although rarely used, the Massachusetts reformatory perhaps in its small way proved useful to the plea-bargaining regime. In his 1906 commentary on the operations of the criminal justice system in Manhattan, Arthur Train recognized the complicated relationship between New York's reformatory at Elmira, on which the Concord reformatory was modeled, ${ }^{736}$ and the plea-bargaining system. On the one hand, Train wrote, because "the Elmira sentence is indeterminate, the defendant has nothing to gain by pleading." 737 On the other, court officers who wanted to encourage guilty pleas sometimes told defendants of the "joys of Elmira." 738 Despite the uncertain length of a sentence to Elmira, therefore, some defendants perhaps preferred that option because they feared worse conditions elsewhere. Other defendants may have had geographical preferences-the reformatory at Elmira (or Concord) might have been closer to family and friends than the state prison at Auburn (or Charlestown). In any event, as long as judges had no obligation to send convicts to Elmira or Concord, then by adding this option to the mix, the legislature simply added one more axis along which judge, prosecutor, and defendant could cut a deal. In fact, although Middlesex judges exercised the Concord option only rarely, the great majority of defendants who received a reformatory sentence had pled guilty. Only thirteen percent of those who went to the reformatory in 1890 had gone to trial and lost-a figure that rose to thirty-one percent in 1896, but then shrank to eight percent in 1900 and a mere five percent in 1910 . The corresponding figures for other institutions were almost always between two and five times as great. ${ }^{739}$

From Train's description of Elmira and this evidence of sentencing practices in Middlesex, we may conclude three things: First, because indeterminate sentences generally did not appeal to defendants, judges and prosecutors rarely found the reformatory option helpful in the pleabargaining process, and the great majority of convicts served their time elsewhere. Second, when defendants did happen to prefer a sentence to the

736. In 1877 , the New York legislature provided that judges would not set the length of sentences to the new reformatory at Elmira, but that convicts could not be held beyond the maximum term specified by law for their crime. See Act of Apr. 24, 1877. ch. 173, § 2, 1877 N.Y. Laws 186, 186.

737. TRAIN, supra note 199 , at 165 .

738. Id. at 173 ("Court officers ... anxious that the particular [courtroom] to which they are assigned shall make as good a showing as possible in the number of cases disposed of ... [contrast the] joys of Elmira ... with other places of confinement ....").

739. In $1890,46 \%$ of those sent to the house of correction and $44 \%$ of those sent to state prison had lost at trial. In 1896 , these figures stood at $34 \%$ and $86 \%$, respectively; in 1900 , at $16 \%$ and $19 \%$, respectively; and in 1910, at $16 \%$ and 26\%. See Middlesex Super. Ct. R. Books (Feb. $1890,1900)$. The numbers in all categories declined between 1896 and 1900 as trials became rarer and guilty pleas more completely dominated dispositions. See supra Figure 4. 
reformatory over one to another institution, judges were pleased to accommodate them in the interests of gaining a plea. And third, when defendants instead refused to plead guilty, insisted on their trial right, and lost, judges rarely sent them to the reformatory. That is, judges generally did not delegate the measure of punishment to the authorities who controlled release from the reformatory, for those authorities might not sufficiently tax the defendant for having burdened the court with a trial. Instead, judges usually punished defendants who lost after trial by imposing a more definite sentence: They sent them for a specified term to another institution.

With the reformatory enjoying but small popularity among Massachusetts judges, the legislature tried to advance the ideal of the indeterminate sentence in other ways-first by instituting parole for state prisoners in 1894 and then by requiring judges to specify minimum and maximum terms to the state prison in 1895. The 1894 law made state prisoners eligible for release on parole at the discretion of a parole board after serving two-thirds of their term. ${ }^{740}$ Advocates of the true indeterminate sentence dismissed parole regimes as poor imitations because they merely permitted a limited reduction of an otherwise fixed sentence. Yet of all regimes that approached true indeterminacy, parole surely was the most significant: By 1900, twenty states had adopted some form of parole, but only eleven had put in place a more nearly indeterminate sentence along the lines of the Concord/Elmira model. ${ }^{741}$

With the 1895 law, the Massachusetts legislature tried to advance the simple parole system one step closer to true indeterminacy. The law provided that "the court imposing the sentence [to state prison] shall not fix the term of imprisonment, but shall establish a maximum and minimum term for which said convict may be held in said prison." 742 It then provided that the convict would be eligible for parole at any time after completing the minimum term. ${ }^{743}$ Again, the law by no means achieved true indeterminacy: Not only did the judge dictate both a floor and a ceiling for every sentence, but the maximum terms defined by statute still constrained the judge's discretion. ${ }^{744}$ But again, laws following this model spread across the nation, taking hold in twenty-three states by $1925 .^{745}$

740. See Act of May 26, 1894, ch. 440, §1, 1894 Mass. Acts 492, 492.

741. See Lindsey, supra note 560 , at 40 .

742. Act of June 5, 1895, ch. 504, § 1, 1895 Mass. Acts 624, 624.

743. See id. $\S 2$.

744. See id. §1.

745. See Lindsey, supra note 560, at 102-05. In what seems to be a comprehensive review of indeterminate sentence laws, Edward Lindsey listed 23 states in which the judge determined a sentencing range (subject to a statutory maximum) within which the convict could receive parole. Although the range of discretion given the judge varied from state to state, I have excluded from my count one state (Indiana) that required the judge to set minimum and maximum sentences at the minimum and maximum defined by statute. See id. 
Even the limited indeterminacy introduced by these two laws might have inhibited plea bargaining's progress to the extent that they lessened the judge's power to promise defendants a particular sentence. As it was, however, the laws lost much in the translation from theory to practice and soon proved to be no more an obstacle to plea bargaining than was the reformatory at Concord. As with the reformatory, Middlesex judges made little use of these new indeterminate sentences. Although the state prison was the destination for nineteen percent of incarcerated convicts in 1890 , before the laws took effect, that figure fell to ten percent in 1896 and eight percent in 1900 before recovering somewhat to eleven percent by $1910 .^{746}$ In their reluctance to impose minimum and maximum terms to the state prison, Massachusetts judges followed New York judges, who reportedly spurned a similar sentencing option enacted in that state in $18899^{7.77}$

When Middlesex judges did impose state-prison sentences under the new parole regime, they very rarely did so in connection with plea bargains. In 1890, before enactment of the new laws, fifty-six percent of state-prison sentences followed guilty pleas. In 1896, with the laws in place, only fourteen percent did so. These figures go some distance toward explaining the odd retreat in the overall rate of guilty pleas that I found in $18966^{748}$ Yet by 1900 , the rate of guilty pleas not only had recovered, but had advanced a good distance. Eighty-one percent of state-prison sentences that year followed guilty pleas. Something must have changed.

The change appears in the statute book. In 1898, three years after the legislature had required judges to specify minimum and maximum terms to the state prison, it amended the parole law to provide that state-prison inmates "shall be entitled to release from said prison upon the expiration of the minimum term" if they have observed all prison rules and were not punished for prison misconduct. ${ }^{749}$ For any state-prison inmate who behaved behind bars, the judge's sentence now dictated the exact date of release. Notwithstanding the claimed indeterminacy of sentences to the Massachusetts state prison, parties engaged in plea negotiations therefore could predict the date of release with near certainty. My search has uncovered no evidence of the legislature's motives in changing the law, but the results of the change were both predictable and immediate: With all the indeterminacy boiled out of the state-prison sentencing scheme, plea bargaining returned and advanced apace.

746. Even in absolute terms, the number of convicts sent to the state prison fell sharply between 1890 and 1900. For both 1890 and 1896. I studied only one (erm of court (of three). In the February 1890 term, the Middlesex Superior Cour handed down 16 state-prison sentences. In October 1896, it imposed only seven. There were 16 such sentences in all of 1900 and 19 in all of 1910.

747. See RUGGLES-BRISE, supra note 559, at 16; Lindsey, supra note 560. at 36.

748. See supra Figure 4.

749. Act of Apr. 25, 1898, ch. 371, 1898 Mass. Acts 312, 312. 
Evidence from many other states reveals a similar aversion to any parole scheme that approached true indeterminacy. Like Massachusetts, New Hampshire required automatic release at the end of the minimum term for prisoners who had not misbehaved behind bars. ${ }^{750}$ Pennsylvania's parole statute did not directly require release at the end of the minimum term, but by commanding the relevant authorities to explain any decision not to release "in writing... in detail," the law probably achieved the same result. ${ }^{751}$ In other states, even absent such statutory commands, decisions of parole boards became very easy to predict. In New York in 1906, Arthur Train reported that a convict sent to Elmira to serve a supposedly indeterminate sentence "will be released in fourteen months if his conduct appears to warrant it" ${ }^{752}$-a figure he repeated a few pages later. ${ }^{753}$ The Prison Association of New York claimed in 1916 that more than ninety percent of parolees in that state won parole either immediately upon completing their minimum term or within one month afterward. ${ }^{754}$ Next door in New Jersey, a report of the following year put the point more directly:

In actual practice parole is granted as a matter of course at the expiration of the minimum term, except in those cases in which the applicant has had his minimum term extended as a penalty for misconduct in prison....

Thus, in all the state institutions[] is the aim of the indeterminate sentence defeated by the policy of the paroling authority. ${ }^{75}$

In 1937, the Harvard Law Review complained in general terms that "[t]he correctional benefits which should result from imprisonment under an indeterminate sentence have often been lost by the mechanical application of parole." ${ }^{756}$ And a modern scholar has concluded that "release at the earliest possible date was [in these early years] a right rather than a privilege." 757

The significance of such predictability is clear: "Indeterminate" sentences would have posed no great obstacle to plea bargaining if negotiating parties could say with confidence when such sentences would

750. See Act of Apr. 6, 1909, ch. 120, § 2, 1909 N.H. Laws 460, 460.

751. Act of June 19, 1911, § 11, 1911 Pa. Laws 1055, 1058.

752. TRAIN, supra note 199 , at 165 .

753. See id. at 179 (noting that at Elmira, a convict "may reasonably expect to be discharged in fourteen months").

754. See PRISON ASS'N OF N.Y., SEVENTY-SECOND ANNUAL REPORT OF THE Prison ASSOCIATION OF NEW YORK: PRISON PROGRESS IN 1916, at 79 (1916).

755. I STATE OF N.J., REPORT OF THE PRISON INQUIRY COMMISSION 62-63 (1917).

756. Legislation-Indeterminate Sentencing Laws-The Adolescence of Penocorrectional Legislation, supra note 730, at 683.

757. NEWMAN, supra note 387, at 37. 
end. ${ }^{758}$ In fact, in an odd way, a parole system that embraced automatic release dates might have been the best of all possible worlds for plea bargaining: Such a scheme permitted the parties to agree upon a sentence that sounded long enough to satisfy the public's desire for harsh punishment, but in reality was short enough to entice the defendant to plead. ${ }^{759}$

Still, it is not clear why parole boards should so quickly have abandoned the principles of parole and adopted a practice of nearly automatic release dates. Sheer overwork must have played a part: A New York review committee found that during a twelve-month period in 1917 and 1918, the state's parole board met forty times to consider 1411 parole applications-or about thirty-five applications per day. ${ }^{700}$ At a quarter-hour per case, the board could hardly make an intelligent individualized judgment about each prisoner's fitness for parole. Parole boards in Massachusetts and Illinois and probably many other places faced similarly overwhelming dockets. ${ }^{71}$ Perhaps such boards felt that the only fair

758. As one observer wrote in 1925, "If prison and parole authorities tend to regard an indeterminate sentence with maximum and minimum expressed as practically equivalent to a definite sentence for the minimum period, it is not surprising that the prisoner should take it that way." Lindsey, supra note 560 , at 77.

During my time as an assistant district attomey in Middlesex County between 1987 and 1991, all parties understood that the defendant's release at the earliest eligibility date was a near certainty. A typical part of the plea-negotiation process was therefore to calculate that date- often a difficult process given the various complicated and overlapping parole statutes. I recall one bargaining session that took place among the lawyers and the judge in the judge's chambers during which the judge phoned an official of the parole board to confirm our understanding of the defendant's first eligibility date if a contemplated sentence was imposed. Our doubts setuled, the case quickly pled out. Cf. Alschuler, supra note 137, at 108-09 (citing 1960s trial lawyers who explained that predictable release on the earliest parole-eligibility date facilitated plea bargaining).

759. In Massachusens, before the "truth-in-sentencing" reform movement of the carly 1990s, the disparity between a sentence's "face value" and its true meaning often was enormous. The most extreme examples were sentences to the reformatory at Concord, which remains in operation today. What was then known as a "Concord 20" - a sentence officially expressed as "twenty years' confinement, to be served at the Massachusetts reformatory at Concord" - provided for parole eligibility and almost certain release after two years. MASS. REGS. CODE tit. 120, \$202.01, at 27 (1990); cf. Alschuler, supra note 137, at 109 (citing a trial lawyer who explained the advantages of a parole system in which lenient sentences appeared harsh to the public).

760. See REPORT OF THE PRISON SUR VEY COMMITTEE 248 (1920). The committee concluded that " $[t]$ here is obviously a defect in the system of reporting to this board adequately the conduct and working history of these inmates, or it would be impossible for any such number of applications to be heard in any such time." Id.

761. In Massachusetts in the early 1920s, it was "impossible" for the two full-time members and one part-time member of the state's parole board "to make a careful personal investigation into the merits of each prisoner's claim to parole." Sam B. Warner. Factors Determining Parole from the Massachusetts Reformaton', 14 J. CRIM. L. \& CRIMINOLOGY 172. 174 n.1 (1923-1924).

In Illinois, between 1917 and 1927, four persons reviewed every parole case in the state. "It soon became apparent that [they] were unable to hear enough cases to unburden the prisons of their congestion, even through the parole of such prisoners who were good parole prospects.... [T] hose who were paroled were little short of having been 'guessed out' of prison." Albert J. Hamo, The Workings of the Parole Board and lis Relarion to the Court, in THE WORKINGS OF THE INDETERMINATE-SENTENCE LAW AND THE PAROLE SYSTEM IN ILLINOIS 67. 67 (photo. reprint 1979) (1928). 
alternative in the circumstances was to adopt a rigidly defined early release date. Or perhaps prison overcrowding demanded release at the earliest eligibility date. In either case, we see at work the same impulse toward efficiency that helped power the plea-bargaining system.

Judges did not depend entirely on early release dates and the cooperation of parole boards to maintain the determinacy of supposedly indeterminate sentences. In Massachusetts, after the 1898 law change ensured release at the end of the minimum term for prisoners who did not misbehave in prison, judges attempted to keep control of the release dates even of those inmates who broke prison rules and had to serve out their maximum terms. In 1900, the average state-prison sentence in Middlesex County called for a minimum term of four years and a maximum term of 5.2 years. The judges therefore rejected the advice of Warren Spalding, an advocate of the indeterminate sentence and a former secretary to the state board of prison commissioners, who wrote in 1895 that to accomplish the goals of the indeterminate sentence, judges should leave a margin of at least three years between the minimum and maximum terms of short state-prison sentences and a margin of at least five years in longer sentences. ${ }^{762}$ By compressing the gap between minimums and maximums, judges deprived the parole board of almost all discretion in setting release dates. In 1910, Middlesex judges approached closer to Spalding's target and imposed an average state-prison sentence of 5.8 to 8.2 years. Still, commentators in Massachusetts and elsewhere continued to press demands that judges not squeeze all the indeterminacy out of minimum/maximum sentencing schemes. ${ }^{763}$ As the Harvard Law Review wrote in 1937, "[T] he history of indeterminate sentence legislation is not without attempts by judges to

762. See WarRen F. SPALDING, INDETERMINATE SENTENCES FOR PENITENTIARY PRISONERS: A PAPER PREPARED FOR THE NATIONAL PRISON CONGRESS 1895. at 10 (n.p. 1895). Spalding wrote:

The court will undoubtedly consider the two purposes which led to the establishment of this form of sentence, viz., the effect on the convict in prison, and the effect upon him after he is discharged. The maximum should be enough longer than the minimum to induce the prisoner to make a hard struggle for his liberty. The pressure of the reformatory system cannot be brought to bear upon him, successfully, unless he has this inducement. There should certainly be a margin of three years upon the shorter sentences, and of five years on the longer ones, to enable the administration to make a successful appeal to the prisoner for his co-operation.

Id.; see also Conlon's Case, 148 Mass. 168, 169 (1889) (identifying Spalding as secretary of the Board of Commissioners of Prisons).

763. See, e.g., Harry Elmer Barnes, The Evolution of Penology in Pennsylvania 322-23 (1927) (advocating more broadly spaced minimum and maximum sentences in Pennsylvania); Winthrop D. Lane, A New Day Opens for Parole, 24 J. CRIM. L. \& CRIMINOLOGY 88, 107 (1933) (presenting the view of a New Jersey parole director that "[s]entences should be indeterminate... [with] real differences between the minimum and maximum"): see also WILCOX, supra note 563, at 18 (noting that "[a]t times the spread between the maximum and minimum limits of the sentence imposed is so small that boards of parole are given little discretion with regard to the time at which prisoners may be released" - though at other times, the spread was sufficiently generous). 
defeat the purpose of these acts by fixing the minimum term at slightly less than the maximum." " 664 Several states in fact legislated specifically against this judicial avoidance tactic. ${ }^{765}$

It is of course possible that judges resisted the indeterminacy of the new sentencing schemes merely because they resented the legisiature's invasion of their sentencing power. ${ }^{766}$ Plea bargaining perhaps benefited, therefore, from the fortuity that judges' pride happened to prefer a more definite sentencing structure. And for that matter, it is possible that the nation's parole boards regularly released inmates at their earliest eligibility date only because it was efficient to do so and not because such predictable practices facilitated plea bargaining. It is possible, in other words, that the link between plea bargaining and the downfall of the indeterminate sentence is causal only in the sense that both served the interests of judges and both served the interests of efficiency. Other evidence, however, suggests a more direct and purposive connection between plea bargaining and the receding ideal of the indeterminate sentence.

We begin to see a glimmer of such a causal link in a report on the Massachusetts parole board written by Professor Sam Warner of the Oregon Law School in the early 1920s. ${ }^{767}$ Warner focused on parole from the Massachusetts reformatory. ${ }^{768}$ As we have seen, sentences to the reformatory came rather close to true indeterminate sentences. ${ }^{769}$ Judges imposed no minimum or maximum term, and hence no law required release upon expiration of the minimum term. Warner found that in the exercise of its very broad discretion to set the date of release, the parole board gave a clear if modest preference to those convicts who had pled guilty rather than go to trial. Although about eighty percent of those granted parole had pled

764. Legislation-Indeterminate Sentencing Laws-The Adolescence of Penocorrectional Legislation, supra note 730 , at 681 ; see also EDWIN H. SUTHERLAND, PRINCIPLES OF CRIMINOLOGY 482 (1934) ("When the cour was given authority to fix limits within the limits fixed by the legislature some judges who were opposed to indeterminate sentences abused their authority by making the minimum almost identical with the maximum.").

765. See, e.g., Act of Mar. 9, 1911, ch. 200, § 1, 1911 Idaho Sess. Laws 664. 664 (providing that minimum term shall not exceed one-half of the statutory maximum term); Act of June 7, 1905 , ch. 184, § 2, 1905 Mich. Acts 268, 268 (providing that the minimum term shall not exceed one-half of the statutory maximum term); Act of Feb. 10, 1917, ch. 16, $\$ 1.1917$ Mont. Laws 16, 16 (providing that the minimum term shall not exceed one-half of the maximum imposed): Act of Apr. 21, 1911, ch. 191, § 2, 1911 N.J. Laws 356, 356 (providing that the minimum term shall not exceed one-half of the statutory maximum term); Act of May 4, 1909, ch. 282, $\$ 1,1909$ N.Y. Laws 511, 512 (providing that the minimum term shall not exceed one-half of the maximum imposed); Act of June 29,1923, ch. 397, §6, $1923 \mathrm{~Pa}$. Laws 975, 976 (providing that the minimum term shall not exceed one-half of the maximum imposed).

766. Friedman and Percival report that Alameda County judges imposed longer prison terms after the legislature enacted a good-time law and a parole law. The judges apparently wanted to keep sentences at their old length. See FRIEDMAN \& PERCIVAL, supra note 135, at 215-16.

767. The Massachusetts Department of Correction commissioned the study. See Sanford Bates, Preface to Wamer, supra note 761, at 172.

768. See id. at 174 \& n.1.

769. See supra note 733 and accompanying text. 
guilty, only sixty-seven percent of those not granted parole had done so. ${ }^{770}$ These numbers suggest that one reward for pleading guilty may have been a readier release on parole.

A far stronger causal link between plea bargaining and early release on parole emerges from a 1928 report on the Illinois parole system written by Dean Albert J. Harno of the University of Illinois Law School. ${ }^{771}$ Harno and fellow members of a review committee "found that occasionally serious problems arise between the [Parole] Board and the state's attorney and even the trial judge over representations made to a prisoner when his plea of guilty is secured." ${ }^{772}$ Harno condemned the practice of making "a promise to the [defendant] or [giving] an intimation to him that if he pleads guilty he will be released, or is likely to be released, after a specified period of confinement." 773 Harno quoted one prosecutor who frankly wrote the superintendent of the state's reformatory in reference to three young inmates:

Prior to sentence Judge ... and I agreed that on a plea of guilty we would recommend parole on the minimum time, providing, of course, that the boys, or any one or more of them, had conducted themselves in a manner to warrant parole. ${ }^{774}$

Other letters to the parole board followed-from the judge, defense counsel, police chief, and (again) the prosecutor-all relating or suggesting the same deal. ${ }^{775}$ One defense lawyer noted that the judge and prosecutor "advised me they had never known of any case wherein the Parole Board had disregarded a joint recommendation from the State's Attorney and the Presiding Judge." ${ }^{776} \mathrm{He}$ added that "the State of Illinois will do these boys a great injustice if they do not admit them to parole now." 777 Another lawyer on the same case wrote that "the State should in good faith try to carry out that to which the State's Attorney and the Trial Judge pledged them in so far as they had the power to pledge them." 778 Although Harno's study did not extend beyond Illinois, and although I have found no clear evidence of "parole bargaining" in Massachusetts or other states, I suspect nonetheless that the practice was widespread. After all, by the time of

770. See Bates, supra note 761 , at 202 . Wamer did not provide the statistic that would have been most useful for my purposes: the proportion of those who pled guilty (versus those who lost at trial) who won parole. See id.

771. See Harno, supra note 761.

772. Id. at 89 .

773. Id.

774. Id. (quoting a letter without attribution by name).

775. See id. at 89-90.

776. Id. at 90 (quoting an unnamed lawyer).

777. Id.

778. Id. (quoting an unnamed lawyer). 
Harno's report, guilty-plea rates in the vast majority of American cities exceeded seventy percent and almost every state had a parole law. ${ }^{\text {n9 }}$

There is one last piece of evidence-this one of a more modern vintage-that suggests that the indeterminate sentence's demise may have proceeded directly from judges' and prosecutors' determination to persevere in plea bargaining. Around the turn of the twentieth century, at least six states, including California, adopted parole laws that approached close enough to a true indeterminate-sentencing scheme to raise a genuine challenge to the vitality of plea bargaining. In a certain range of cases, these statutes deprived the judge of all power to measure the term of confinement to state prison. ${ }^{780}$ Instead, when a judge sent a convict to state prison, the parole board unilaterally set the date of release, constrained only by the minimum and maximum terms imposed by law. Such a regime raised obvious obstacles to any plea-bargaining scheme: Not only did it leave judges powerless to promise a particular release date to defendants who pled guilty, but it also disabled them from imposing a certain and harsher penalty on defendants who risked trial and lost. That is, even to the extent that judges or prosecutors could have persuaded parole authorities to release convicts who pled guilty at their earliest eligibility dates-an action that might have suited the boards' interests in avoiding prison overcrowding or in developing an easy rule of thumb for the treatment of most prisoners-it might have been far more difficult to persuade those same boards to penalize those convicts who did not plead guilty by keeping them beyond their first release dates. In contrast, under a typical parole system, judges could punish recalcitrant defendants who burdened the court with a trial by imposing harsh minimum terms that, even when reduced by the amount the parole law permitted, still penalized defendants for their poor choices.

Despite these obstacles, California judges, prosecutors, and defense lawyers adapted their plea-bargaining tactics to this regime too-and in ways that once again frustrated the goals of the indeterminate sentence. Lynn Mather's study of the operations of the Los Angeles County courts in the early 1970s shows that by that time, only six percent of accused felons ultimately convicted of a crime ever went to state prison. Instead, the vast majority of convicts originally charged with felonies secured a mere misdemeanor conviction and either received probation or served time in a

779. In Moley's sampling of 24 American urban jurisdictions, all but three had guilty-plea rates of $70 \%$ or more. See Moley, supra note 47 , at 105. Edward Lindsey reported that in 1922, 44 states had some form of parole law. See Lindsey, supra note 560, at 69.

780. See Act of May 18, 1917, ch. 527, \$1, 1917 Cal. Stat. 665, 665-66; Act of June 28, 1919, § 3, 1919 Ill. Laws 436, 437; Act of Mar. 15, 1897, ch. 143. \$§ 1, 3, 5, 1897 Ind. Laws 219. 219-221; Act of Mar. 13, 1903, ch. 375, $§ 1,1903$ Kan. Sess. Laws 571. 571-75; Act of Mar. 3, 1911 , ch. 169, § 1, 1911 S.D. Laws 209, 209; Act of Feb. 11, 1903, ch. 45, § 46, 1903 W. Va. Acts $138,149-50$. 
lesser institution, or both. ${ }^{781}$ The most important axis along which plea bargaining took place became the distinction between a state-prison term and no state-prison term. Mather reports that when the charged offense called for mandatory state-prison time, plea bargaining often took the form of prosecutorial charge bargaining, for without a prosecutor's motion, the judge could not reduce the charge to one that permitted a lesser penalty. ${ }^{782}$ But when the judge had the discretion to choose between imposing and not imposing state-prison time, plea bargaining tended to take place directly between the judge and defense counsel by a process known as "chamberizing": The judge and lawyers would meet in the judge's chambers, where the judge could spell out or hint at the sentence she would impose should the defendant plead guilty. ${ }^{783}$

Albert Alschuler reports another means of evading the California parole authorities' power to dictate the length of sentence. In the 1960s, when Alschuler observed court business in San Francisco, defendants often pled guilty and were then sentenced to an indeterminate term in state prison. Instead of putting that sentence into effect, however, the judge would suspend it and impose probation during the term of suspension. Then, as a condition of probation, the judge would impose a county-jail term. ${ }^{784}$ By judicial sleight of hand, a seemingly illegal jail term took the place of a seemingly mandatory state-prison term-and all in accord with the law. Thanks to such ingenious devices, by the time California officially abandoned its experiment with the indeterminate sentence in $1976,{ }^{785}$ there was very little indeterminacy left.

This brief sketch of the indeterminate sentence's slide from prominence suggests that several different causal strands may have tied plea bargaining's continued rise to the indeterminate sentence's demise. Judges, prosecutors, and defense lawyers, first of all, may have evaded the indeterminacy imposed by the new laws by bargaining for definite sentences at certain institutions rather than indefinite sentences at others. Second, some state legislatures acted to require or encourage release on parole at the earliest opportunity and thus restored the predictability that plea bargaining needed to thrive. Third, judges may have erased the

781. See MATHER, supra note 489 , at $5,28,30$.

782. See id. at 30. Mather reports a toothless policy put in place by the district attorney in 1974, purportedly to limit plea bargaining:

Interestingly, in the one exception allowed by the new policy, district attorneys could still agree (with prior written approval from their superior) to a sentence bargain of " no state prison." This particular sentence commitment ... was crucial in "serious" cases and was one of the most common bargains before the policy change.

Id. at 153 n. 4 .

783. See id. at 31-33.

784. See Alschuler, supra note 137 , at 101-03 \& n.126.

785. See CAL. PENAL CODE $§ 1168$ (a)(1) (Legal Book Corp. 1976), repealed by Act of Sept. 20,1976 , ch. $1139, \S 272.5,1976$ Cal. Stat. 5140 . 
indeterminacy from minimum and maximum sentences by setting the minimum term close to the maximum and thereby contriving predictable sentences that could lure defendants into pleading guilty. Fourth, parole officials may have rewarded those convicts who pled guilty with earlier release dates and hence may have created a direct incentive for defendants to strike plea bargains. Fifth, some judges and prosecutors appealed to parole authorities to stand by promises made in the course of plea negotiations that the defendant would walk free on a certain date. Finally, a single cause-overcrowding in the criminal justice system-may have promoted both the efficiency of plea bargaining and the nearly automatic decisions of some parole boards to release convicts at their earliest eligibility date, a practice that in turn facilitated plea bargaining by making release dates more predictable. This multiplicity of mechanisms, each supported by evidence from separate sources, makes it highly unlikely that the historical correlation between plea bargaining's rise and the indeterminate sentence's fall was simple coincidence. By various devices, those forces that impelled plea bargaining's progress also compelled that the indeterminate sentence make way.

\section{Public Defenders}

Moving from the indeterminate sentence to public defenders, we change focus from an institution that threatened plea bargaining and was defeated by it to an institution that fostered plea bargaining and was fostered by it. At the moment of their founding, public defenders' offices and other organizations for the defense of the poor owed a direct debt to plea bargaining: The advocates who promoted these institutions in the early decades of the twentieth century staked their case in part on the claim that public defenders would be good for plea bargaining and therefore good for the justice system. Whether these advocates indeed believed or hoped that public defenders would encourage more guilty pleas is not so clear-it is clear only that they perceived a strategic advantage in claiming that this result would follow. They therefore borrowed from plea bargaining's prestige in the echelons of legal power to promote the cause of their pet reform. That the institutions that resulted in fact have helped plea bargaining consolidate its position may not have been the reformers' intent, but it was the nearly inevitable result of their actions.

Not all early advocates claimed that public defenders would facilitate guilty pleas, ${ }^{786}$ but one of the most prominent did so frankly. In 1915 Mayer Goldman saw his proposals for a public defender fail before the New York

786. See infra notes $803-808$ and accompanying text. 
legislature. ${ }^{787}$ In a defense of his bills published two years later, ${ }^{788}$ Goldman seemed at first to promise that under a public defender system, there would be fewer guilty pleas. He complained that the lawyers who were assigned to represent indigent defendants under the system that then prevailed in New York persuaded even their innocent clients to plead guilty, ${ }^{789}$ and he claimed the public defender system would "minimize[]" guilty pleas. ${ }^{790}$ In several passages in his short book, however, Goldman made it clear that he wished to minimize guilty pleas only by innocents, and that his proposed public defender would strive to secure guilty pleas from the guilty:

His function would not be to defeat justice-but to promote it. He should co-operate with the district attorney, whenever not inconsistent with his duty to his client, and wherever possible, in order to bring about an ideal administration of the law. His duty should be to protect the innocent-not to acquit the guilty. He should see that the guilty is fairly punished-not over-punished. ${ }^{791}$

"The law would not require nor expect a public defender to endeavor to acquit a guilty person," Goldman continued later, "any more than that the prosecutor is expected to convict an innocent person." "792 To corroborate his view of the public defender's role, Goldman quoted a New York judge who predicted that

[i]f the public defender's office were well and honestly conducted, I think... that a large number of perjured defenses would be eliminated and honest defenses or pleas of guilty substituted which

787. See MAYer C. Goldman, THE PUBlic Defender: A NeCESSARy FaCtor IN THE ADMINISTRATION OF JUSTICE at vii-viii (1917).

788. See id.

789. [A]ssigned counsel, whose retained clients are his chief concem, easily convinces himself that he has done his duty to his pauper client if the prosecutor will accept a plea of guilty to a lesser form of crime or be content to recommend a moderate sentence.... That such a system results in innocent men being branded and punished as criminals admits of no doubt.

Id. at 21-22 (quoting from an address of Samuel Untermeyer); see also id. at 70 ("How many innocent men have pleaded 'guilty' at the suggestion of assigned counsel, because of the latter's indifference or desire to escape the burden of trial, it is impossible to state; their number must be legion."); REGINALD HEBER SMITH, JUSTICE AND THE POOR 114 (1924) ("If not paid, [the professional assigned counsel] is perfectly willing to betray his client by neglecting the case, or forcing him to plead guilty, or deserting him altogether.").

790. GOLDMAN, supra note 787 , at 35,49 .

791. Id. at 8.

792. Id. at 40. Goldman repeated this view at least twice more. See id. at $45-46$ ("The indigent defendant, who is innocent, would be the only one really benefited by the services of the public defender-except that the guilty would be saved from over-punishment."); $i d$. at 67 ("A district attorney is not expected to, nor should he, prosecute a person whom he knows or believes to be innocent. Why, therefore, should a public defender be criticized for a failure to defend one whom he believes to be guilty?"). 
would not only be conducive to good public morals but would save much time and labor in the courts and would reduce the calendar. ${ }^{793}$

Perhaps taking their cue from Goldman's advocacy, the nation's fledgling public defenders declared it to be their goal to win guilty pleas from guilty clients. In a 1918 report, the Los Angeles public defender took unabashed pride in his office's pursuit of efficient and truthful outcomes:

We have not felt that it was our duty to oppose the district attorney, but rather to cooperate with him in setting all the facts before the courts.... Our office has tried to keep uppermost the idea that justice should be done and even in criminal cases attorneys should not try to get the defendants "off" regardless of the merits. We have not asked for unnecessary delays and have not resorted to technicalities. ... In cases where there is no question of the guilt of the accused, it is the established rule of the office that no trials should be held but that pleas of guilty be entered, thereby saving the county the expense and delay of trials. ${ }^{794}$

In New York, the Voluntary Defenders' Committee ${ }^{795}$ announced in its 1917 prospectus that " $[w]$ hen a voluntary defender finds that he has a guilty man on his hands he will not set out to acquit him." ${ }^{796}$ Rather, "[t]he first essential step towards improvement is a confession of guilt." 797 A few years later, the Committee added that "counsel's duty does not require that the state be compelled to prove the guilt of a defendant confessedly guilty." 798 And in Omaha, the newly established public defender likewise emphasized his attitude of cooperation and not confrontation with the district attorney: "The examination by the county attorney and public defender in all alleged crimes, results in many judgments by the court

793. Id. at 41 (quoting Judge Charles $C$. Nott). It is possible that Judge Nott was a former prosecutor, which perhaps would make his views on the proper role of the public defender somewhat suspect. See TRAIN, supra note 199, at 155 n.* (identifying Chartes Cooper Nott, Jr. as a New York prosecutor as of 1905 ).

794. Walton J. Wood, The Annual Repon of the Los Angeles Counny Public Defender, $9 \mathrm{~J}$. CRIM. L. \& CRIMINOLOGY 289, 289-90 (1918) (emphasis added).

795. The Voluntary Defenders' Committee was founded in 1917 and soon became part of the Legal Aid Society of New York, a private organization that provided legal services to the poor. See Michael McConville \& Chester L. Mirsky, Criminal Defense of the Poor in New York Ciny, 15 N.Y.U. REV. L. \& SOC. CHANGE 581, 614, 617-18 (1986-1987). New York did not inuroduce public funding of criminal lawyers for the poor until 1951. See id. at 633.

796. Notes and Abstracts: The Voluntary Defenders Commintee, 8 J. CRIM. L. \& CRIMINOLOGY 278, 282 (1917-1918).

797. Id.

798. LEGAL AID SOC'Y, 45TH ANNUAL REPORT, VOLUNTARY DEFENDERS' COMMITTEE 69 (1920). 
satisfactory to both the state and the accused, thus saving Douglas County considerable sums that would otherwise be expended in useless trials." 799

The Omaha defender's claim of cost efficiency, echoed by both the Los Angeles and New York defenders, ${ }^{800}$ raises suspicions that these various declarations by fledgling defenders were more public-relations gestures than expressions of honestly held views. After all, defenders' offices relied on public or donated funds to provide a service often seen as subversive of effective law enforcement. Just as claims of cost efficiency went far to win public acceptance, so too perhaps did eager denials of hopes to gain freedom for the guilty. It is not easy at this distance to disentangle the beliefs of early public defenders and their sponsors from their rhetoric. After reviewing the many studies and commentaries that accompanied the rise of New York's Voluntary Defenders' Committee, Michael McConville and Chester Mirsky emerged convinced that these declarations were genuine: "The primary goals of the indigent defense system have been and remain to make the criminal law a more effective means for securing social control at minimal expense" - a goal achieved by "minimiz[ing] adversarial advocacy, and therefore the cost of criminal defense, by compelling guilty pleas and by other non-trial dispositions." ${ }^{801}$

I am less sure. In the heated atmosphere of the early days of the publicdefender movement, as state legislatures and private bar associations balked at the expense of these new organizations and fretted about their potential to empower the guilty poor, ${ }^{802}$ disavowals of zealous advocacy made too much strategic sense to be taken at face value. It is worth noting that one of the more temperate and establishment-bound of the early backers of the public defender system, Reginald Heber Smith of the Boston law firm Hale and Dorr ${ }^{803}$ made it plain that he believed even confessedly guilty clients

799. GOLDMAN, supra note 787, at 53 (quoting an Omaha public defender). Albert Alschuler reports a strikingly similar boast by a more modern public defender. See Albert W. Alschuler, The Defense Attomey's Role in Plea Bargaining, 84 YALE L.J. 1179, 1207 (1975) (quoting a California public defender's claims in 1969 that the establishment of his office cut the rate of felony trials in his county by almost half and that the court's presiding judge praised his program as "materially assist[ing] the court in the administration of justice . . a considerable savings to the taxpayers of Santa Clara County").

800. See LEGAL AID SOC'Y, 51ST ANNUAL REPORT, VOLUNTARY DEFENDERS' COMMITTEE 64 (1926) ("If the Committee had not been so successful in arriving at dispositions without trials, it might have been necessary to try several hundred cases, at an enormous expense to the community."); Walton J. Wood, Necessity for Public Defender Established by Statistics, 7 J. CRIM. L. \& CRIMINOLOGY 230 (1916-1917) (arguing that because the public defender raises fewer technical obstacles than private counsel, trials are quicker and therefore cheaper).

801. McConville \& Mirsky, supra note 795, at 877; see also id. at 631 (stating similar conclusions). Though I disagree with some of their analysis, I am grateful to McConville and Mirsky for leading the way through the voluminous materials documenting the rise of the New York Voluntary Defenders' Committee.

802. See Foltz, supra note 441 , at 401 \& n.2.

803. See McConville \& Mirsky, supra note 795, at 596. 
should have a trial and a defense if they wanted one. ${ }^{804}$ And although Smith reported with no apparent disapproval the success of public defenders in persuading their guilty clients to plead guilty, ${ }^{805}$ he did not hail the promise of increased guilty pleas as a reason to embrace the new institutions. Clara Foltz, an earlier and more radical advocate of the public defender, avoided even the pretense of promising that a good defender would encourage guilty pleas. Instead she lamented that defendants without counsel and those represented by inadequate assigned counsel had little choice but to plead guilty ${ }^{806}$-and she insisted that "one-half of those arrested and charged with crime are actually innocent, and in the eyes of the law all of them are so." 807

But Foltz's words, written in 1897, moved no legislature to establish a public defender. By the second decade of the next century, when Goldman wrote his defense and the first cautious legislatures dared take up the experiment, ${ }^{808}$ supporters had grown savvier and now promised cost efficiency and ready plea bargaining. It is perhaps a bit of a paradox that this new advocacy frankly recognized the importance of plea bargaining, which the exposés of the next decade pretended to reveal to the world. Apparently, while the world was waiting for a series of law professors to discover the prevalence of plea bargaining, ${ }^{809}$ those lawyers and other

804. See SMITH, supra note 789, at 121 ("It is the strongly prevailing present opinion of the bar that [when a client who has confessed guilt to her lawyer refuses to plead guilty] it is the lawyer's duty to defend, ... requiring the state to prove fairly the truth of its charges.").

805. See id. (noting that "[i]n practice this issue [of defending the guilty at trial] has not presented itself" because "[i]n New York, all defendants who have admitted guilt have been persuaded to be honest with the court and plead guilty" (citations omitted)): id. at 119 (reporting that the Los Angeles public defender "instructs more of his clients to plead guilty than did assigned counsel under the former regime, and... tries only cases where he has faith in the defendant").

806. Innumerable innocent boys and girls and men and women are recorded as pleading guilty and railroaded into jail because too dazed to understand their rights and legal position. Hundreds of men and women plead guilty because advised to do so by some court or police officer and fear makes them obey. Others plead guilly and suffer punishment by fine because it is cheaper than counsel and they can better stand the disgrace than the money loss....

…

[Assigned lawyers] are often caught up without a moment's notice and compelled to go to trial without adequate time to prepare on the law or to secure testimony. The defense is almost of necessity inadequate, and about the wisest course for a pauper prisoner caught in the mesh of misunderstanding or circumstantial evidence is to plead guilty, eam consideration by "saving the county expense," and throw himself on the "mercy of the court."

Foltz, supra note 441 , at 393,399 (footnote omitted).

807. Id. at 402 (footnote omitted).

808. Goldman reported that Oklahoma established the nation's first public defender in 1912, but that the first of the sort he envisioned took office in Los Angeles in 1914. See GoLDMIAN, supra note 787 , at $81-82$.

809. The four authors and editors of the three most prominent studies of the 1920s all were law professors-Roscoe Pound and Felix Frankfurter al Harvard, see CRIMINAl JUSTICE IN Cleveland (Roscoe Pound \& Felix Frankfurter eds.) (1922), Raymond Moley at Columbia, see Moley, supra note 47, at 97, and Justin Miller at the University of Southem California, see 
officials who were more familiar with the day-to-day work of the courts already understood how useful it could be to claim that the public defender would spread plea bargaining even further.

Having come into being on a promise, however strategically and insincerely made, that they would facilitate plea bargaining, public defenders apparently proceeded to do just that. Figures comparing the work of early public defenders with that of other criminal lawyers are rare, but they do exist for Los Angeles in 1913-1914. The public defender reported that his office resolved seventy percent of its cases by guilty plea-as opposed to sixty-two percent for private counsel assigned to represent indigent defendants and a mere forty-nine percent for paid lawyers. ${ }^{810} \mathrm{~A}$ few years later, both the Los Angeles public defender and the New York Voluntary Defenders' Committee claimed they had persuaded every client who confessed guilt to counsel to do so in court. ${ }^{811}$ A 1923 report of the New York committee disclosed that staff lawyers confronted clients with evidence of their guilt to persuade them to plead guilty. ${ }^{812}$ That these offices in fact promoted plea bargaining is not surprising given their promises to do so. Whether public or charitable, institutional defenders had to report on their operations and constantly justify their continued funding. Regular boasts that high guilty-plea rates were yielding the promised cost savingsthe New York Voluntary Defenders' Committee made such claims almost annually ${ }^{813}$ - constituted a centerpiece of their survival strategy.

But broader institutional pressures no doubt also played a role in generating high guilty-plea rates. Because public defenders did all of their lawyering within a single county before a limited set of judges and against a fixed group of prosecutors, they were apt to be more concerned than more mobile lawyers with earning and keeping the goodwill of those judges and prosecutors. Their reasons were not necessarily selfish. If judges became

MILLER, supra note 274, at 1 . Miller, it is true, formerly was a district attorney of Kings County. California. See Miller, supra note 274, at 1.

810. See Wood, supra note 800 , at 230.

811. See Legal AID SOC'Y, RePORT OF VOluntary DEFENDERS' COMMITTEe 3 (1917):

William W. Clary, The Public Defender, 7 POMONA C. Q. MAG. 49, 56 (1918).

812. The notable feature of our work is the large number of persons who plead guilty .... These pleas are not always the immediate and open confession of guilt which the figures might imply. We have often been compelled to make extensive investigations into facts, which when revealed to our clients, have resulted in their admissions of guilt.

LEGAL AID SOC'Y, 48TH ANNUAL REPORT, VOLUNTARY DEFENDERS' COMMITTEE 73 (1923).

813. See, e.g., LEGAL AID SOC'Y, supra note 800, at 64 ("If the Committee had not been so successful in arriving at dispositions without trials, it might have been necessary to try several hundred cases, at an enormous expense to the community."); LEGAL AID SOC'Y, 52D ANNUAL REPORT, VOLUNTARY DEFENDERS' COMMITTEE 70 (1927) (reporting that 283 defendants pled guilty in 1927 and claiming that "[b]y so doing they secured material advantages to themselves. and the community was saved enormous expense"); LEGAL AID SOC'Y, 53D ANNUAL REPORT. VOLUNTARY DEFENDERS' COMMITTEE 83 (1928); LEGAL AID SOC'Y, 55TH ANNUAL REPORT. VOLUNTARY DEFENDERS' COMMITTEE 66 (1930). 
disaffected with the public defenders and refused to appoint them to represent indigent defendants, then clients would suffer as well as lawyers. And good relations with the district attorney could be good for the clientele. An early official of the New York Voluntary Defenders' Committee wrote in 1928 that when a defender's client was innocent, the lawyer would lay the evidence of innocence before the district attorney, who would "recommend to the Court the immediate dismissal of the charge." 814 The claim implied that the credibility that defenders gained by advising their guilty clients to plead guilty proved useful when they advocated on behalf of the innocent. The reports of public defenders consequently brag in a decidedly non-adversarial way about how their high guilty-plea rates won praise and cooperation from their courtroom counterparts. ${ }^{815}$

Beyond securing the support of their financial sponsors and the approval of prosecutors and judges, defenders had a more selfish interest in seeing their clients plead guilty: They were overworked. ${ }^{816}$ Unlike private lawyers who earn more when they work more and can adjust their workloads to their needs, public defenders have only limited power to moderate their labors. ${ }^{817}$ They are in fact in nearly the same position as prosecutors and judges, whose ranks only the legislature can expand, though the legislature shares none of their workload and faces instead only the constant pressure to cut costs. The imperative of efficiency that moved both prosecutors and judges to embrace plea bargaining therefore now works to ensure that a large proportion of the defense bar shares in the same cause.

\section{Principles of Procedural Change}

If plea bargaining's symbiotic relationships with probation and public defenders and its unhappy encounter with the indeterminate sentence had been three disconnected stories, then we would have a trilogy of evolutionary tales but no theory of evolution. I believe, though, that a fairly simple evolutionary thread runs through these stories. To find it, we should

814. William Dean Embree, The Voluntary Defenders, 28 LEGAL AID REV. 1, 4 (1928).

815. See LEGAL AID SOC'Y, supra note 798, at 69 (reporting that the committec's policy of refusing to take cases to trial of defendants who admitted their guilt "had the approval of judges in the Court of General Sessions"); see also Louis Fabricant. The Voluntary Defender in Criminal Cases, 124 ANNALS 74, 77 (1926) ("We never try to dodge the facts of a case. Pleas of guilty are not withheld where the facts given us by our clients warrant such a plea. Confidence is thus inspired both in the court and the prosecutor.").

816. See McConville \& Mirsky, supra note 795, at 627 ("The first forty years of the existence of the Defenders' Committee were marked by moderate increases in staff size and a great expansion of its caseload.").

817. See, e.g., Cooper v. Fitzharris, 551 F.2d 1162, 1163 n.l (9th Cir. 1977) (recounting a public defender's account of her collapse under the weight of 2000 cases per year in a case alleging ineffective assistance of counsel), modified en banc, 586 F.2d 1325 (9th Cir. 1978). 
not focus on the ways these three institutions helped or hurt plea bargaining. Those mechanisms were as different as the institutions themselves. Hence probation aided plea bargaining both by offering a new penalty for which minor offenders could bargain and by supplying an officer who told the court about the crime and criminal, making it possible to pass a well-informed sentence without trial. Public defenders helped plea bargaining by funneling many defendants into an advocacy institution so chronically overburdened that it had little recourse but to join prosecutors and judges in a regular practice of plea bargaining. And the indeterminate sentence endangered plea bargaining by threatening to deprive judges and prosecutors of the power to promise fixed concessions that could tempt defendants to plead guilty.

The theme that unites these three stories is not their impact on plea bargaining, but rather plea bargaining's impact on them. In each case, two fairly simple causal mechanisms ensured that those institutions that helped plea bargaining would thrive and any that hurt it would wither. The first was the sheer exercise of power by judges and prosecutors who stood united in a common preference for bargains over trials. The second was the pressure of business and the consequent imperative of efficiency, which both impelled judges and prosecutors toward their common preference for pleas and operated directly on other actors in the system to move them to assist in plea bargaining's rise.

In the case of probation, we saw the first mechanism most clearly at work. I argued in Parts II and III that during the second quarter of the nineteenth century, when the practice of on-file plea bargaining took root. part-time prosecutors felt enormous pressure to lighten their workloads. Judges felt this pressure less keenly, however, and they had other objections to plea bargaining as well, so prosecutors had to seek out plea-bargaining methods that required no participation by the judge. The on-file technique served this purpose by permitting prosecutors to promise a fixed concession-that no sentence would be imposed unless the defendant again broke the law-without any endorsement by the court. More versatile than prosecutorial charge bargaining, which relied on the fortuity of a rigid penalty scheme, on-file plea bargaining became more popular as the century wore on. Eventually it won the favor of judges, who gradually took it over. By the last quarter of the century, when the civil-caseload revolution demanded that judges sharply limit their criminal workloads, the on-file technique had become arguably the most important weapon in plea bargaining's arsenal. In 1900, on-file plea bargains accounted for forty-one percent of all case adjudications, and the number of defendants who insisted on trial and still secured the favor of a filing approached zero. As this same technique-putting cases on file and staying sentence unless the defendant again misbehaved-eventually took the name probation, it is fair to say that 
prosecutors and judges fashioned probation as an instrument of plea bargaining.

In the case of the public defender, both evolutionary mechanisms took part in ensuring that this new friend of plea bargaining would find fortune. The early-twentieth-century advocates of the public defender thought it wise to claim that defenders would encourage guilty pleas. That claim was sure to please the judges and prosecutors who sponsored plea bargaining, and their good opinion no doubt influenced the legislatures and private legal foundations that established the first public defenders. Once in place, the new defenders found that staying in the judge's favor was essential to survival because the judge dictated who would represent an indigent defendant. Staying in the prosecutor's favor was important because the prosecutor's cooperation could ensure the quick and certain release of innocent clients. The wages of such favor, of course, were taking part in plea bargaining and not contesting the guilt of the guilty. Though the ethics of such devil's deals might have troubled some defenders, sheer overwork perhaps eased their consciences. Here the second evolutionary mechanism-the imperative of efficiency-came into play. Unable to represent more than a fraction of their clients at trial, public defenders must have felt justified in allocating scarce trials to those who seemed innocent and in negotiating the best possible deals for the rest.

The case of the indeterminate sentence likewise revealed both evolutionary mechanisms at work, though the first mechanism, in which judges and prosecutors protected plea bargaining's viability by directly discouraging the indeterminate sentence, operated most prominently. Many judges spurned broad use of their new indeterminate-sentencing options. In Middlesex County and elsewhere, they rarely imposed indeterminate sentences to the state reformatory, made less use of the state prison once sentences to that institution became less determinate, and contrived to defeat the purpose of minimum/maximum sentencing laws by squeezing out the gap between minimum and maximum terms. Occasionally, judges or prosecutors compromised the parole process by promising parole release on a certain date as part of a deal and then asking parole authorities to go along. We see the second evolutionary mechanism at work in the decisions of parole boards to avoid thousands of individualized decisions by adopting automatic or nearly automatic release dates. Automatic release not only eased the boards' workloads and helped relieve prison overcrowding, but also restored enough certainty to the length of confinement to permit plea bargaining to carry on.

In the end, though, the best evidence that plea bargaining has held evolutionary sway over its sibling institutions of criminal justice may not be our ability to spell out evolutionary principles that link the success of those institutions to the interests of plea bargaining, but our inability to name a 
single important procedural innovation of the last 150 years that threatened to choke off plea bargaining and flourished. I have considered already all of the most prominent innovations in this period except the due process revolution of the Warren Court. The Court's sweeping guarantees of a variety of rights to the criminal accused, both time-consuming in themselves and time-consuming to enforce, surely threatened the systemic efficiency that plea bargaining served so well, but they did nothing to threaten plea bargaining itself. Precisely because these rights added so much time to the processes of trial and appeal, ${ }^{818}$ advocates and judges had even greater incentives to achieve compromise. And efficiency aside, the due process revolution deepened the concerns that trial judges and prosecutors had for the apparent legitimacy of their acts. Facing a trial minefield littered with exploding error, they were even readier to bargain than before. ${ }^{819}$

Fortunately, the same new rights that created these incentives to plea bargain also created the opportunity to do so, for every new right supplied a new axis along which a bargain could be struck. By sacrificing the chance of freedom promised by a sloppy search warrant, a defendant could win an extra concession on a plea. ${ }^{820}$ Fortunately, too, the Supreme Court considered few of its newly guaranteed rights nonwaivable and declared without embarrassment that the defendant could relinquish virtually all of them in a plea bargain to escape the full force of the prosecutor's threatened sentence. ${ }^{821}$

In only one, largely insignificant way has the due process revolution cramped plea bargaining's progress. I argued in Part IV that the defendanttestimony laws of the latter half of the nineteenth century, which gave defendants the right to offer sworn evidence at trial, moved many of the most accomplished criminals to plead guilty instead. Because juries would regard the silence of a defendant who had the right to speak as a sign of guilt, and because prosecutors could impeach those who spoke with

818. Albert Alschuler speculates that the due process revolution contributed to greater trial lengths. In Los Angeles, the average felony trial grew from 3.5 days in 1964 to 7.2 days in 1968 . See Alschuler, supra note 2, at 38 . One could argue, in contrast to those who have claimed that the increasing procedural complexity of our modern trials made plea bargaining inevitable by making trials too cumbersome and expensive, see id. at 40-41; Langbein, supra note 519, at 3, 9-11, that the causal chain ran largely the other way. That is, the Supreme Court might not have dared lavish time-consuming trial rights on criminal defendants if plea bargaining had not already climinated all but a tiny proportion of trials.

819. See Alschuler, supra note 2, at 39.

820. See id. at 38 ("In the words of an Oakland public defender, 'rights are tools to work with,' and rather than insist on a hearing on a motion to suppress illegally obtained evidence, a defense attomey was likely to use a claim of illegality to exact prosecutorial concessions in plea bargaining.").

821. See Bordenkircher v. Hayes, 434 U.S. 357, 363-65 (1978); North Carolina v. Alford, 400 U.S. 25 (1970); Parker v. North Carolina, 397 U.S. 790 (1970); McMann v. Richardson, 397 U.S. 759 (1970); Brady v. United States, 397 U.S. 742 (1970). 
evidence of their past convictions, defendants who carried the burden of a criminal record found themselves trapped in a procedural catch-22. The situation was worst in those states that permitted prosecutors to comment to juries on the defendant's silence and thereby stir up their natural suspicions. ${ }^{82}$ In 1965, however, the Supreme Cour ruled that such comment violated a defendant's right against self-incrimination. ${ }^{823}$ Moreover, the law of evidence has evolved to make judges somewhat slower to admit evidence of past crimes to impeach criminal defendants. ${ }^{824}$

Although these developments operate against plea bargaining's interests by making trials more viable for defendants who otherwise might have felt compelled to strike a deal, they have had no far-reaching impact. Defendant-testimony laws appear to have played a smaller role in plea bargaining's rise than, for example, the civil-caseload revolution of the same period or the rise of probation. Moreover, prosecutorial comment on silence probably added little to the power of defendant-testimony laws to discourage trials. As Arthur Train wrote in 1906 in a state that barred such comment, ${ }^{825}$ "The writer has heard more than one talesman say, in discussing a verdict, 'Of course we couldn't take it against him, but we knew he was guilty because he was afraid to testify." ${ }^{226}$ Such sentiments no doubt continue to discourage trials among defendants with bad records except when defendants are able to persuade judges to keep evidence of their records out. That is, if a ruling that bars comment on the defendant's silence constitutes the only procedural advance of the last century and a half that challenges plea bargaining's onward march, then plea bargaining has faced remarkably feeble resistance.

\section{THe Balance of POWER To Plea Bargain}

Here the reader might object that at least one twentieth-century procedural innovation, the non-jury trial, has arisen in the path of plea bargaining. Until now, I have used "trial" as a shorthand for "jury trial" because a jury sat in judgment at virtually every trial held in the intermediate and upper-tier courts of Middlesex County during our

822. State legislatures immediately recognized the risk of burdening defendants' exercise of their right against self-incrimination, and many of the earliest defendant-testimony laws banned comment on defendants' silence. See, e.g., Act of May 26, 1866, ch. 260. 1866 Mass. Acts 245. 245 ("N]or shall the neglect or refusal to testify create any presumption against the defendant."). Many states, however, imposed no such ban. See, e.g., Act of Mar. 25, 1864, ch. 280. 1864 Me. Acts 214, 214.

823. See Griffin v. Califomia, 380 U.S. 609, 613 (1965).

824. See supra note 468 and accompanying text.

825. See Act of May 7, 1869, ch. 678, \& 1, 1869 N.Y. Laws 1597, 1597 (" [B]ut the neglect or refusal of any such person to testify shall not create any presumption against him.").

826. TRAIN, supra note 199 , at 161. 
period. ${ }^{827}$ It is true that on the lowest tier of the Massachusetts judiciary, a lone magistrate rendered verdicts in the most petty criminal trials. ${ }^{828}$ It is also true that other states provided more broadly for non-jury trials in misdemeanor cases. ${ }^{829}$ But not until the early twentieth century did more than a few states give defendants facing felony charges the option to waive a jury trial and put themselves instead on the judgment of the court. ${ }^{830}$

There are two reasons to expect that giving defendants a broad right to choose non-jury trials might have stalled the plea-bargaining juggernaut. The most obvious is that non-jury trials appear to eliminate or at least moderate the main incentives to plea bargain. Because they are relatively quick, they make the efficiency advantages of plea bargaining shrink in comparison. Because experienced and savvy judges are less likely to reject powerful evidence of guilt than are a dozen randomly chosen laypersons, prosecutors can be less fearful of capricious acquittals and more willing to go to trial. And because it is difficult to generate reversible error before a judicial factfinder, judges can be less fearful of reversals and the resulting damage to their reputations.

The second reason to expect that non-jury trials might have slowed plea bargaining's rise looks not to the balance of incentives between trial and plea, but to the balance of power between judge and prosecutor. Raymond Moley, probably the earliest theorist of the dynamics of plea bargaining, predicted in 1928 that non-jury trials would reallocate courtroom power in a way that might cause "an immediate decline in the proportion of pleas of guilty." 831 "It would seem," he wrote, "that the way to restrict the discretion of the prosecutor is to give wide powers to the judge." 832 Nonjury trials would undermine prosecutors' power to plea bargain in a way

827. Of the several thousand cases I reviewed, exactly one appeared to me to involve a nonjury trial-and even in that case the record was ambiguous. See Commonwealth v. Artemas G. Upham, Middlesex Ct. C.P. R. Book 18 (Feb. 1853) ("[A]fter hearing the witnesses (duly sworn) and fully hearing and understanding the defence, it appeared to the said Court that the said Upham was guilty...."). This case concerned the misdemeanor of selling milk by an unapproved measure.

828. See supra note 8.

829. Between 1846 and 1893, at least 12 states (not including Massachusetts) acted to permit non-jury trial in misdemeanor cases. See Susan C. Towne, The Historical Origins of Bench Trial for Serious Crime, 26 AM. J. LEGAL HIST. 123, 149 \& n.131 (1982).

830. Although fairly common in some American colonies, non-jury trials in felony cases virtually died out by the end of the 18th century. They did not emerge except in scattered instances until the late 19th century, when Connecticut, Louisiana, and Indiana acted to permit non-jury felony trials. (Maryland already did so.) See id. at 148-50. Only in the 20th century did the practice spread more broadly. See id. at 123-24.

831. Moley, supra note 47 , at 127.

832. Id. 
that no "direct attack upon the practice of prosecutors" could ${ }^{833}$-by investing judges with a competing power to resolve cases efficiently. ${ }^{834}$

History has proved false all such theories of the impact of non-jury trials. Within a decade of Moley's prediction, most states permitted nonjury felony trials, ${ }^{835}$ and by 1960 , every state did so ${ }^{836}$ But plea bargaining marched on and now accounts for a higher proportion of criminal dispositions than it did when virtually every felony had to be tried by jury. ${ }^{837}$ Informed by this hindsight, we can see now that there never was good reason to think that a broader right to non-jury trial would hold back plea bargaining's progress.

Consider first how the incentives of costs and risks play themselves out in the typical plea negotiation. If the defendant regards his chances of acquittal at trial to be, say, thirty percent, ${ }^{838}$ he normally will demand in exchange for his guilty plea a deduction of about thirty percent from the sentence he would have faced had he gone to trial and lost. (Those defendants who value certainty for its own sake will demand a smaller deduction, while those who regard immediate prison time as more painful than future time will demand a larger one.) The prosecutor, who is spared a thirty-percent risk of loss, normally will be willing to grant this concession plus a concession that reflects the saved expense and effort of trial. As the prosecutor normally is willing to give more than the defendant demands, the parties almost always find common ground. And as the judge is spared both the time of trial and the risk of reversal, she almost never stands between the parties and their deal. Trials therefore take place only when the parties calculate the odds of acquittal differently or something else interferes with their freedom to bargain. There is no reason the option of a non-jury trial should alter this calculus greatly. At a non-jury trial, the defendant still has some chance of acquittal, though smaller, and the prosecutor still expends time and money, though less. There is every reason to expect that the prosecutor will continue to offer a discount from the post-

833. Id.

834. See id. ("The fundamental treatment for the tendency which we have discussed in this article is not a direct attack upon the practice of prosecutors. Their range of methods by which criminal charges can be disposed of is so great that merely to shut off one practice will open up others.").

835. See Alschuler, supra note 2, at 33.

836. See KALVEN \& ZEISEL, supra note 460 . at 22 \& n.18.

837. See Alschuler, supra note 2, at 33. Alschuler suggests that the non-jury trial may have depressed the proportion of plea bargains, though only for a shon time. He reports that in 1936, after many states had acted to permit non-jury trials, the proportion of plea bargains was lower than in the 1920s, but then resumed its upward trend and had recovered any loss by 1940. See id. at 33. As the figures he uses reflect state cour practice, see id., the end of federal Prohibition cannot provide a ready alternative explanation for the decline in pleas between the 1920 s and 1936.

838. To keep this illustration simple, I will assume the chance of reversal on appeal is subsumed in the chance of acquittal after trial. 
trial sentence that is greater than the discount the defendant demands-and so the parties reach common ground about as readily as before.

If the availability of non-jury trials has influenced the rate of plea bargaining, it is not because non-jury trials have altered the parties' incentives to deal, but because a small amount of plea bargaining power now has shifted from prosecutor to judge. Moley anticipated such a power shift, but because he misperceived the existing dynamic of bargaining power, he mistook the significance of the shift. His belief that prosecutors alone drove the plea-bargaining process permitted him to conclude that judges would restrict plea bargaining if only they could. But as our long immersion in the records of Middlesex County has made plain, prosecutors never could conduct much of a plea-bargaining practice on their own. Absent judges' cooperation, Massachusetts prosecutors of the first threequarters of the nineteenth century maintained at best an underground resistance of plea bargaining, contriving a charge-bargaining practice from the liquor law's and murder statute's rigid penalty schemes and an on-file plea bargaining practice from their procedural power to withhold a motion for sentence. Only after judges came over to plea bargaining's side in the last quarter of the century did plea bargaining achieve the dominance that Moley discovered in his studies of the 1920s. Nothing but the full-fledged participation of judges could explain how the guilty-plea rate in Middlesex County reached eighty-seven percent by the end of the century. As the vast majority of these cases arose under statutes that assigned broad sentencing discretion to the judge, most plea bargains depended on the judge's confederacy in the cause.

In fact, judges may have grown to be even greater advocates of plea bargaining-or at least of certain plea bargains-than prosecutors. Both theory and later practice suggest that judges deployed the new power given them by non-jury trials not to rein in plea bargaining, but to spur it on in the face of occasional prosecutorial opposition. Consider the relative interests that judge and prosecutor bring to the plea-bargaining process. In the average case, a bargain saves time for both judge and prosecutor, but in addition hands victory to the prosecutor, and so we are accustomed to think of the prosecutor as having the greater interest in striking a deal. In many cases, however, the judge maintains an efficiency-based interest in a plea bargain (as well as an interest in avoiding the risk of reversal), but the prosecutor stands opposed. Prosecutors, after all, must face reelection before a constituency that may regard plea bargaining as a prosecutor's capitulation to expediency. Even if the public stands indifferent to plea bargaining in general, it is likely to demand a full measure of punishment in 
certain cases, or certain kinds of cases, that prompt great fear or outrage. ${ }^{839}$ In contrast, even those judges who must face the electorate rarely take responsibility for plea bargains, which the public usually assigns to prosecutors. On the higher plane of principle, prosecutors trained as advocates might see the defendant's crime as more vile and might peg the odds of conviction higher than would the judge and therefore might consider the case to be "worth" more on a plea. As a consequence, the judge might be more willing than the prosecutor to offer the defendant an acceptable concession for his plea.

Normally, such disagreements between judge and prosecutor pose no obstacle to a successful plea bargain. The judge, after all, controls the sentence and therefore simply offers the defendant a larger concession than the prosecutor thinks right. But where the statutory penalty scheme imposes a harsh minimum sentence for a particular offense, the prosecutor's refusal to reduce the charge can thwart the judge's desire to deal. Now we see how the non-jury trial can shift the balance of power decisively toward the judge. When the judge believes that a plea bargain on the defendant's terms is appropriate, but the prosecutor withholds the nol pros that could make the deal possible, the judge has a trump card. She can advise the defendant to elect a non-jury trial on the understanding, spoken or otherwise, that the judge will work her own nol pros simply by finding the defendant not guilty of so much of the prosecutor's charge as stands in the way of the lower sentence the judge wants to impose. ${ }^{840}$ The prosecutor now confronts a dilemma: He may persist in his refusal to deal and embark upon a timeconsuming trial with a predetermined result, or he may succumb to the terms of the bargain and secure the sentence that the judge perceives as fair without the trial. ${ }^{841}$ Overpowered by the judge, the resource-wise prosecutor submits-and deals.

839. Lynn Mather reports that when the Los Angeles district attomey took up a campaign to become California's attomey general in 1970, his office forbade prosecutors to cngage in a form of charge bargaining that had been routine in cases of marijuana possession. See MATHER, supra note 489, at 17-18. "After all, the district attomey is a political animal," one prosecutor explained to Mather. "Drugs are a very controversial issue right now." Id. at 18.

840. During my tenure as a Middlesex County prosecutor, this situation arose most often in cocaine-distribution cases. Massachusetts law imposes an escalating series of mandatory minimum prison terms according to the quantity of cocaine found in the defendant's possession. Many judges regarded the sentences- 3 years for 14 grams (one-half ounce), 5 years for 28 grams, 10 years for 100 grams, and 15 years for 200 grams, see MASS. GEN. LAWS ANN. ch. 94C. $\S 32 E(b)(1)-(4)$ (West 1997)-as unjustifiably harsh and pressured prosecutors 10 consider reducing the charged offense in exchange for a plea, especially when the defendant had no other criminal record. Our office rigidly enforced a policy against any such reduction. Judges therefore advised or hinted to defense counsel that they would, on a non-jury trial, find reasonable doubt as to the weight of the cocaine and find the defendant guilty of possessing a smaller quantity than that charged.

841. Lynn Mather describes a Califomia adaptation of the non-jury trial that, although not resulting in a plea bargain, substitutes for a plea bargain in a procedurally ingenious way. I noted earlier that until the California indeterminate-sentence law was repealed in 1976, judges had no 
In a world in which plea bargaining dominates the mechanisms of criminal justice, the option of non-jury trials may achieve the best possible balance of the power to deal. The defendant who wishes to regulate her risks by striking a bargain can hold out for the best terms that either judge or prosecutor will offer. The defendant's dealmaking need not be subject to the whims of either officer because the agreement of one normally is enough for the deal to proceed. The judge, as I have said, can strike a bargain even without the prosecutor's compliance. If, on the other hand, the judge rejects a deal arranged between defendant and prosecutor, the prosecutor often can limit the judge's options in sentencing by selectively nol prossing charges or parts of charges to guarantee the defendant a concession in exchange for her plea. In the end, it is rare that either judge or prosecutor can scuttle a deal by insisting on a harsher sentence than the other thinks right.

But two conditions, coming together, can destroy this balance of power. The first is that the prosecutor have the power to veto a non-jury trial and insist instead on trial by jury. In our federal system and in many states, the prosecutor has retained this power. With it, he can exact the full measure of punishment prescribed by those statutes that impose a minimum punishment below which the judge may not dip. The second condition is that there be many such statutes. In our federal system and in those states that have adopted rigid sentencing guidelines, the entire criminal code now approaches this form. By assigning a narrow range of sentencing options to virtually every criminal violation and by giving judges only limited power to impose a sentence below that range, guideline systems have invested prosecutors with the power to dictate almost every sentence by choosing one set of charges over another.

power to dictate the length of state-prison sentences, and so plea bargains often turned on the distinction between a sentence to the state prison and one to a lesser institution. $C f$. Act of Sept. 20,1976 , ch. $1139, \S 271,1976$ Cal. Stat. 5061,5139 (giving judges the authority to impose sentences as prescribed by statute); supra notes 780-785 and accompanying text. The judge often could not avoid imposing a state-prison sentence, however, unless the prosecutor first reduced the charged offense. Mather reports that in Los Angeles County, the district attorney often forbade courtroom prosecutors to reduce charges without clearance from their superiors. To achieve the same end as the plea bargain without any reduction in charge, the lawyers would agree to a "submission on the transcript." This was a non-jury trial in which the only evidence presented to the judge was the transcript of the preliminary hearing. The parties understood that the judge typically would find the defendant guilty of a lesser offense and avoid sending the defendant to state prison. Afterward, the courtroom prosecutor could report to her superiors that the judge (and not she) had reduced the charge. See MATHER, supra note 489, at 19-20,55-58. 
Though this new imbalance of plea-bargaining power might somewhat advance plea bargaining's fortunes, ${ }^{8+2}$ we should not expect it to change the face of plea bargaining in America. It is true that in Massachusetts during the first three-quarters of the nineteenth century, the prosecutor's power to dictate penalties by manipulating charges in liquor-law and murder cases helps explain why plea bargaining emerged first in those contexts. One might suppose that by converting the entire criminal code to the form of the old Massachusetts liquor laws, sentencing guidelines would set off a pleabargaining frenzy. But times have changed. In the early nineteenth century, judges did not share the prosecutorial urge to plea bargain. Plea bargaining took hold in liquor and murder cases because rigid penalty schemes gave prosecutors the power both to guarantee a sentencing concession should the defendant plead and to guarantee a harsher sentence should the defendant choose trial and lose-and to do both without the judge's help. Today, judges so rarely oppose a plea agreement struck by defendant and prosecutor that plea bargaining takes place with enormous regularity even when the governing statute gives the judge a nearly free hand in sentencing. With or without sentencing guidelines, therefore, plea bargaining is likely to happen whenever the concession the prosecutor is willing to offer is greater than the concession the defendant demands-or nearly all of the time.

We should, however, expect the new imbalance of plea-bargaining power to weaken the defendant's hand in bargaining. The combination of

842. The numbers tell an odd story. For several years after the U.S. Sentencing Guidelines took effect in 1987, the rate of plea bargaining in federal district courts, measured as a proportion of adjudicated cases, held almost perfectly steady. Then, for unclear reasons, it began to trend up. This trend lagged so far behind adoption of the Guidelines that it seems likely that other causes must have played a part:

PLEA BARGAINING IN FEDERAL DISTRICT COURTS:

CASES ENDING IN PLEAS OF GUILTY OR NO CONTEST AS A PROPORTION OF ALL ADJUDICATED CASES

\begin{tabular}{|c|c|}
\hline 1984 & $84 \%$ \\
\hline 1985 & $85 \%$ \\
\hline 1986 & $84 \%$ \\
\hline 1987 & $85 \%$ \\
\hline 1988 & $84 \%$ \\
\hline 1989 & $84 \%$ \\
\hline 1990 & $84 \%$ \\
\hline 1992 & $85 \%$ \\
\hline 1993 & $86 \%$ \\
\hline 1994 & $88 \%$ \\
\hline 1995 & $89 \%$ \\
\hline 1996 & $90 \%$ \\
\hline 1997 & $91 \%$ \\
\hline 1998 & $92 \%$ \\
\hline
\end{tabular}

Source: BUREAU OF JUSTICE STATISTICS, SOURCEBOOK OF CRIAINAL JUSTICE STATISTICS-1998, at 407 tbl.5.21 (1999). 
rigid sentencing guidelines and the prosecutor's prerogative to veto nonjury trials means that the only actor in a federal courtroom with the power to shorten a sentence the prosecutor demands is the jury. But the jury normally does not know the sentencing consequences of its actions, and neither party may appeal to it in those terms. The defendant, who formerly could sound out both judge and prosecutor and take the best deal offered, now has but one bargaining partner, and that is the one least likely to look at things the defendant's way. In fact, though the causes are varied, the average time served by federal convicts since the U.S. Sentencing Guidelines took effect in 1987 has lengthened considerably. ${ }^{843}$

With this odd juxtaposition of the old Massachusetts liquor laws and our very modern sentencing guidelines, we now can see how far we have come. Something more than 150 years ago, plea bargaining in Massachusetts claimed but a tiny beachhead. Supported only by the desire of prosecutors to manage their crushing workloads and to gain an occasional effortless conviction, plea bargaining extended no further than the sentencing power of prosecutors. In liquor and murder cases, the legislature's perhaps imprudently designed penalty schemes gave prosecutors the sliver of power they needed to support a meager chargebargaining practice. By the middle of the nineteenth century, plea bargaining had stolen to a larger outpost, the on-file form of plea bargaining, left exposed to prosecutors by the procedural fluke that judges could not pass sentence until the prosecutor so moved. There the progress of plea bargaining might have stalled, for the sentencing power of prosecutors reached little further.

Then, in the last quarter of the nineteenth century, judges found themselves confronted by an onslaught of new, and newly complex, civil suits brought on by the ravages of industrial machinery. They saw no choice but to make terms with the new order in the criminal courts. They

843. The facial length of the average sentence has remained deceptively constant. Between 1982 and 1986 (the last half-decade before the Guidelines took effect), the average length of sentences handed down by federal district courts ranged from 57.2 months to 64.6 months, with the figures trending upward. Between 1988 and 1998, that figure ranged from 58.6 months to 69.6 months, with the figure dipping downward in the last three years. See BUREAU OF JUSTICE STATISTICS, supra note 842 , at 408 tbl.5.22. But the average defendant nonetheless has fared far worse. That is in part because the likelihood of getting prison time as opposed to probation has risen dramatically. In the five years before the Guidelines took effect, prison sentences accounted for a nearly steady proportion of all sentences of either imprisonment or probation-varying only from $55 \%$ to $57 \%$. In the first 11 years after the Guidelines took effect, that proportion grew steadily larger, from $58 \%$ in 1988 to $79 \%$ in 1998 . See id. Moreover, although the facial length of sentence has stayed almost unchanged, the elimination of parole under the Guidelines has changed the meaning of the facial sentence considerably. In pre-Guidelines years, before federal parole was abolished, federal convicts became parole-eligible after serving only one-third of their terms. See Theresa Walker Karle \& Thomas Sager, Are the Federal Sentencing Guidelines Meeting Congressional Goals? An Empirical and Case Law Analysis, 40 EMORY L.J. 393, 393 n.4. 414 (1991). 
embraced plea bargaining and turned their considerable sentencing power to its purpose. Sustained now by the two most powerful courtroom patrons, plea bargaining swiftly became the dominant force in criminal procedure. It pushed aside the indeterminate sentence, and it supported those institutions, such as probation and the public defender, that aided its cause. Finally, plea bargaining grew so entrenched in the halls of power that today, though its patrons may divide its spoils in different ways, it can grow no more. For plea bargaining has won. 


\section{APPENDIX A: A NOTE ON THE CASES}

Many of my arguments and conclusions rest on an analysis of a large body of nineteenth-century Massachusetts court cases, drawn mainly from Middlesex County. In various footnotes throughout the Article, I have described the records themselves and the protocols I followed in classifying and counting them. For those who would like to pursue similar research or to analyze my findings more critically, I will try to gather together the most important points about the database and my method of analyzing it in this Appendix.

\section{A. The Records and Where To Find Them}

I have relied most heavily on records of the middle-tier courts: the Court of General Sessions of the Peace through 1803; the Court of Common Pleas from 1804 through the first two sessions of 1859; and the Superior Court from late 1859 on. ${ }^{844}$ For a few years during the 1840 s, I examined the records of the Essex County Court of Common Pleas, held at the Essex Superior Court in Salem. Otherwise, my research of middle-tier courts focused exclusively on Middlesex County. The Massachusetts Archives in Boston houses all records of these courts for 1859 and earlier. Records for 1860 and later are stored off-site in a warehouse at the Worcester State Hospital. The record books for most years between 1771 and 1808 and between 1823 and 1839 may be purchased on microfilm from the Genealogical Society of Utah in Salt Lake City.

The records of the court's work take three forms. First are the record books themselves, probably compiled at the end of each session of court, which lay out all case dispositions in beautiful script (until the advent of clerk-typists sometime in the late 1880s) and in an organized way. Cases not disposed of-for example, those continued until the next session of court-are not mentioned. Typically, the record-book entry for each case transcribes the indictment or other charging document and lays out the procedural steps of the case's progress through the court. These include how the defendant pled, whether the prosecutor nol prossed any charge, who composed the jury, the jury's verdict, and the judge's sentence. The record book typically does not say whether the defendant had counsel, who testified at trial, or what facts were proved. Beginning in the late 1840s, record books usually include long lists of cases that are identified only by the defendants' names and are noted, simply, as having been placed on file or nol prossed. 
In the earlier years of this study, the clerk's docket books largely repeat information contained in the record books. Beginning in 1844, however, the docket books fill in several missing details. They tell us which cases the court continued from one session to the next, whether defendants had counsel, what charges were involved in the "filed" and "nol prossed" cases listed in the record books, and whether the defendants in these case pled guilty. They also tally the days consumed by each session of court. Unfortunately, the docket books are far more difficult to read than the record books-they are both messier and more abbreviated. Moreover, not until the last third of the century did the clerk note each case's docket number in the record books. For earlier years, the task of cross-referencing those cases that are listed in both books took time.

The files for each case are the richest source of information, but also the least accessible. They include the original indictment, witness subpoenas, tables of costs, occasional moving papers submitted by one of the lawyers, and (very occasionally) other notes or letters to or from the lawyers. All these are neatly folded together, bundled with ribbons, hardened with time, and boxed away.

I have read the record-book entry for every case relied on in this study. For many, I have read the docket-book entry. For several dozen or perhaps more, I have examined the file papers. For most of the years studied, I have read every case handled by the court that year. As the century wore on and the court's caseload grew, I sometimes read only those cases decided at one or two of the three annual sessions. To extrapolate these partial studies into totals that represent the whole year's work, I have assumed that the caseload of each session of court was proportional to the days consumed by that session. In 1870, for example, I studied only the February session of court. In that session, a single judge sat for 33 days and disposed of 183 cases. As the June and October sessions of court consumed 48 judge-days between them, I have calculated the year's total workload as 449 cases:

$$
((33+48) \div 33) \times 183=449 .
$$

In all, I examined 4142 middle-tier cases in Middlesex. This figure does not include cases identified in the record books merely as having been nol prossed or placed on file unless I also examined the docket-book entry for those cases. Therefore, my case totals are larger for those years for which I also studied the docket books. 
TABLE 11. CASE DATABASE:

MIDDLESEX COUNTY SUPERIOR COURT AND ITS PREDECESSOR COURTS

\begin{tabular}{|c|c|c|c|}
\hline Year & $\begin{array}{c}\text { Number of Cases } \\
\text { Examined }\end{array}$ & Court Sessions & $\begin{array}{l}\text { Docket Books } \\
\text { Examined? }\end{array}$ \\
\hline 1789 & 15 & All & $\mathrm{N} / \mathrm{A}$ \\
\hline 1790 & 8 & All & N/A \\
\hline 1799 & 17 & All & N/A \\
\hline 1800 & 21 & All & N/A \\
\hline 1805 & 21 & All & N/A \\
\hline 1806 & 26 & All & N/A \\
\hline 1809 & 14 & All & $\mathrm{N} / \mathrm{A}$ \\
\hline 1810 & 20 & All & N/A \\
\hline 1814 & 25 & All & N/A \\
\hline 1815 & 45 & All & N/A \\
\hline 1819 & 24 & All & N/A \\
\hline 1820 & 38 & All & N/A \\
\hline 1824 & 48 & All & N/A \\
\hline 1829 & 41 & All & N/A \\
\hline 1834 & 95 & All & N/A \\
\hline 1839 & 42 & All & N/A \\
\hline 1843 & 101 & All & N/A \\
\hline 1844 & 123 & All & Yes \\
\hline 1849 & 443 & $\overline{\text { All }}$ & Yes \\
\hline 1853 & 482 & All & Yes \\
\hline 1859 & 415 & All & Yes \\
\hline 1864 & 225 & Feb. \& Oct. & Yes \\
\hline 1870 & 183 & Feb. & Yes \\
\hline 1874 & 153 & Feb. & No \\
\hline 1880 & 140 & Oct. & Yes \\
\hline 1885 & 105 & June & No \\
\hline 1890 & 232 & Feb. & In Part \\
\hline 1896 & 144 & Oct. & No \\
\hline 1900 & 602 & All & Yes \\
\hline 1910 & 294 & All & No \\
\hline TOTAL & 4142 & & \\
\hline
\end{tabular}

Sources: Middlesex Ct. Gen. Sess. Peace R. Books; Middlesex Ct. C.P. R. \& Docket Books; Middlesex Super. Ct. R. \& Docket Books.

In calculating the court's caseload after 1844, I have included only those years for which I have read the docket books. To maintain consistency across years, I counted only disposed cases-that is, those 
cases that traditionally had been listed in the record books-and omitted any case (such as those continued from one session of court to the next) listed in the docket books but not mentioned in the record books. I believe these protocols guard against the possibility that the caseload boom of the late 1840s, depicted in Figure 2, was simply an artifact of the appearance in 1844 of more elaborate docket books.

My study of the business of the Supreme Judicial Court was less farreaching. For the early part of the century, before the legislature transferred jurisdiction over all but capital cases to the Court of Common Pleas, ${ }^{845}$ I examined the entire business of the high court in several different years. For these early years, the Supreme Judicial Court's docket books added little or no useful information to the record-book entries, and I rarely examined either the docket books or the file papers. As with the middle-tier courts, the record books for 1859 and before are housed at the Massachusetts Archives, while those for later years are kept at the Worcester State Hospital.

TABLE 12. CASE DATABASE:

SUPREME JUDICIAL COURT (SITTING IN MIDDLESEX COUNTY)

\begin{tabular}{|c|c|c|}
\hline Year & $\begin{array}{c}\text { Number of Cases } \\
\text { Examined }\end{array}$ & Court Sessions \\
\hline 1799 & 12 & All \\
\hline 1809 & 24 & All \\
\hline 1819 & 30 & All \\
\hline 1824 & 36 & All \\
\hline 1829 & 20 & All \\
\hline 1834 & 7 & All \\
\hline 1839 & 1 & All \\
\hline 1843 & 0 & All \\
\hline 1849 & 4 & All \\
\hline TOTAL & 134 & \\
\hline
\end{tabular}

Sources: Sup. Jud. CL. R. Books (Middlesex sittings).

My study of the disposition of capital cases examines the Supreme Judicial Court's business for the entire state, not merely for Middlesex County. I drew most of my data not from the court's records, but from the attorney general's annual reports, which usually stated in greater or lesser detail (depending on the year) the procedural course of every capital case heard before the court. The attorney general submitted his reports to the

845. See supra notes 10,125 and accompanying text (describing this jurisdictional shift). 
legislature, which published them, and so they are widely available in both hard-bound and microfilm formats. They did not, however, appear before 1832. For earlier years, I have relied on my survey of the Middlesex sittings of the court as well as on a thorough study of the Suffolk County (that is, Boston) sittings between 1820 and $1832 .{ }^{846}$ For those later years in which the attorney general either did not exist or produced no useful report (18401848 and 1853), I have examined the court's record books for its sittings in Suffolk, Middlesex, Bristol, Hampden, Norfolk, and Worcester counties. ${ }^{847}$ This strategy omitted any capital case arising in one of the state's other eight counties, but I am confident that I have captured the great majority of the state's capital caseload in these years.

\section{B. Counting Cases and Statistical Protocols}

Although some of my research assistants (and in particular Dan Levin) helped me code cases onto a spreadsheet for analysis and others (Josh Greenberg and Craig Estes) helped with the technical task of counting cases, I read every case myself, determined how to classify it, and reviewed the coding for consistency. All of the middle-tier cases from Middlesex are on a single document that is available to others for analysis.

I made several decisions about how to count cases. I believe that all of them are defensible, but few are self-evidently the only right approach. First, I chose not to count as part of any year's court business those cases that were adjudicated in an earlier year, whether by trial or by plea, unless they were re-adjudicated in the year under study. That is, if a case tried in 1858 happened to be disposed of in 1859-perhaps because sentencing was delayed-the clerk typically would record the entire proceedings in the 1859 record book. In my analysis of the business of 1859 , I have omitted such cases.

Second, when performing any count designed to assess the workload of prosecutors or judges (as when calculating caseload for Figure 2), I counted each case as one case even if it involved several defendants. When assessing decisions made by judges, juries, or litigants, however, I followed a different course. Consider, for example, Figure 4, which represents defendants' tendency to plead guilty rather than go to trial. If a particular case had, say, four co-defendants, and if all four went to trial (or all four pled guilty), then I counted the case as one case. But if three of four defendants pled guilty while one went to trial, I counted the case as two separate cases: one that ended in a guilty plea and one that went to trial. Although others might count such a case as four cases (three that ended in a

846. See supra note 92.

847. See supra notes 97,99 . 
plea and one in a trial), I believe my method is more likely to represent the reality behind courtroom decisionmaking. With surprising frequency, codefendants acted (and were treated by the jury) as a unit, a tendency perhaps magnified by the frequent appearance of only one defense lawyer in a case involving multiple co-defendants. As my goal generally was to examine decisions and not outcomes per se, I believe the number of different decisions-rather than the number of actors controlled by those decisions-was the better proxy.

Third, when drawing cross-century comparisons, I often have excluded both liquor cases and cases placed on file. For reasons I have discussed at length in the text, these case types were different from the rest, particularly because the prosecutor possessed far more control over sentencing than he did in other cases. Because both liquor cases and filed cases were either rare or absent early in the century, I felt that including them would too greatly distort any analysis that spanned the century. ${ }^{848}$ For similar reasons, I have excluded them from most analyses designed to gauge judicial decisionmaking. As the century wore on, however, prosecutors lost their peculiar powers in liquor cases ${ }^{849}$ and (to a lesser extent) in filed cases, ${ }^{850}$ and so for late-century studies of judicial decisionmaking, I sometimes have included them. ${ }^{851}$ In all cases, I have tried to specify which course I took.

Fourth, the distinction between liquor and non-liquor cases was itself tricky. Because the significance of this distinction was the rigid penalty scheme that gave prosecutors the unilateral power to charge bargain that I described in Part I, ${ }^{852}$ I have limited "liquor cases" to those cases that arose under the liquor-license laws or under the liquor-prohibition laws that sometimes supplanted them. These laws traditionally-and fairly consistently-maintained mandatory penalty schemes. ${ }^{853}$ I therefore counted drunkenness and common-drunkard cases as "non-liquor cases" because the penalty schemes governing those crimes granted the judge considerable discretion and frustrated prosecutorial charge bargaining of the sort seen under the license law. ${ }^{854}$ After some deliberation, I decided that the odd category of "liquor nuisance" cases, first created by the legislature in 1855 and retained throughout the century, ${ }^{855}$ fits comfortably under

848. See supra notes $44,304-312$ and accompanying text.

849. See supra notes $164,173-177,279-283$ and accompanying text.

850. See supra notes $322-325,370-376$ and accompanying text.

851. See, e.g., supra note 503.

852. See supra notes $36-44$ and accompanying text.

853. See supra notes $22,55,61,173,279,283$ (describing various incamations of the liquorlicense and prohibition laws).

854. See MASS. REV. STAT. ch. 130, § 18 (Dutton \& Wentworth 1836) (providing for a fine "not exceeding five dollars" for a first offense); Act of Mar. 29. 1834, ch. 61, § 2, 1834 Mass. Acts 189, 190-191 (providing for commitment of an unspecified length to a house of correction for being a common drunkard).

855. See supra notes 176,503 (citing statutes). 
neither "liquor cases" nor "non-liquor cases." Because the nature of the offense is essentially unauthorized liquor-selling - the same activity punished by the license and prohibition laws-it seems strained to call these non-liquor cases. But because the penalty scheme did not closely resemble the license and prohibition laws' rigid formulas, ${ }^{856}$ it would be wrong to classify nuisance cases as liquor cases. I therefore have excluded liquor-nuisance cases from both categories, although they are included in tallies of "total" cases, and they appear as well (for reasons explained there) in Table $5^{857}$ and occasionally in other tallies. ${ }^{858}$

Fifth, I have tried to distinguish throughout the text between pleas of guilty and pleas of no contest. At times, however, if the context was clear or the distinction unimportant, I have used "guilty pleas" as a shorthand to represent both. The legal distinction between these pleas was almost insignificant, ${ }^{859}$ but because a plea of no contest was easier for some defendants to swallow, this option often smoothed negotiations toward a plea. Although the earliest clear plea bargains I observed in liquor cases (those in the 1820 s and earlier) always involved pleas of no contest, for later years I saw relatively few no-contest pleas:

856. One of the penalty provisions of the 1855 act gave the judge a good deal of sentencing discretion. See Act of May 19, 1855, ch. 405, $\S 1,2,1855$ Mass. Acts 803, 804 (providing for a "fine not exceeding one thousand dollars, or ... imprisonment ... no[t] more than one year" for maintaining a liquor nuisance). Another gave the prosecutor a good deal of sentencing power by imposing a minimum sentence. See id. $\$ 4$, at 804 (providing for a "fine of not less than one hundred, not more than one thousand dollars, or by imprisonment in the county jail not less than thirty days, nor more than six months"). Even this latter provision, however, probably could not have supported a successful charge-bargaining regime. Although it assured the prosecutor a substantial minimum sentence, it did not protect the defendant against an unreasonable maximum. That is, even if the prosecutor and defendant agreed that the defendant would plead guilty to one count and be fined $\$ 100$, the judge could imprison the defendant for six months.

857. See supra note 503.

858. See, e.g., supra note 334 and accompanying text.

859. See supra note 34. 
TABle 13. Pleas of No CONTEST as a PROPORTION OF ALl PLEAS OF EITHER GUILTY OR NO CONTEST: MIDDLESEX SUPERIOR COURT AND ITS PREDECESSOR COURTS

\begin{tabular}{|c|c|c|}
\hline Year & Total Pleas & \% No-Contest Pleas \\
\hline $1789-1790$ & 16 & $13 \%$ \\
\hline $1799-1800$ & 21 & $57 \%$ \\
\hline $1805-1806$ & 23 & $57 \%$ \\
\hline $1809-1810$ & 14 & $57 \%$ \\
\hline $1814-1815$ & 19 & $47 \%$ \\
\hline $1819-1820$ & 28 & $57 \%$ \\
\hline 1824 & 27 & $52 \%$ \\
\hline 1829 & 21 & $48 \%$ \\
\hline 1834 & 19 & $16 \%$ \\
\hline 1839 & 16 & $0 \%$ \\
\hline $1843-1844$ & 82 & $26 \%$ \\
\hline 1849 & 129 & $9 \%$ \\
\hline 1853 & 72 & $29 \%$ \\
\hline 1859 & 107 & $14 \%$ \\
\hline 1864 & 77 & $5 \%$ \\
\hline 1870 & 59 & $3 \%$ \\
\hline 1874 & 57 & $0 \%$ \\
\hline 1880 & 73 & $7 \%$ \\
\hline 1885 & 69 & $3 \%$ \\
\hline 1890 & 101 & $6 \%$ \\
\hline 1896 & 66 & $5 \%$ \\
\hline 1900 & 471 & $6 \%$ \\
\hline 1910 & 224 & $3 \%$ \\
\hline
\end{tabular}

Sources: Sources: Middlesex Ct. Gen. Sess. Peace R. Books; Middlesex Ct. C.P. R. \& Docket Books; Middlesex Super. C. R. \& Docket Books.

Finally, I have made many other, more minor decisions about how to count cases. The most important of these is that, unless specified otherwise, I counted as a "conviction" any case in which the jury convicted the defendant of any part of the crime charged. I have kept a record of the other decisions I have made and am happy to share them-as well as any of my other data-with future researchers. 


\section{APPENDIX B: FERDINAND'S CATEGORY OF "VICE OR REGULATORY OFFENSES"}

This Appendix refers back to note 214, where I deferred an analysis showing the affinity between what Theodore Ferdinand calls "vice or regulatory" offenses and what I call liquor-law violations.

Ferdinand tells us that "[r]egulatory offenses include liquor law violations, offenses against religion (blue law violations), and city ordinance violations." 860 "Offenses against religion," he then adds, "consisted basically of violations of blue laws prohibiting taverns from serving alcoholic beverages on Sunday." "S61 Section 5 of the 1832 liquorlicense law punished Sunday liquor sales by a mandatory ten-dollar fine for each offense. ${ }^{862}$ By assigning a fixed fine to each offense, this provision gave the prosecutor the same power to engage in multiple charging and charge bargaining that I described in Part I with regard to the rest of the liquor-license law. ${ }^{863}$ Asahel Huntington often charged multiple counts of Sunday sales just as he charged multiple counts under other provisions of the license law, and in fact, one of Huntington's preprinted multi-count forms contained four Sunday sale counts. ${ }^{864}$

Although Ferdinand does not tell us which city ordinances the category of "city ordinance violations" comprehends, he does say that

in the late 1830 s and early 1840 s, arrests for city ordinance violations, liquor law violations, and offenses against religion began to climb sharply ... suggesting that all three were part of the temperance campaign against liquor abuses. When city ordinance violations took a sharp jump in 1848, the other two declined; and when liquor law violations spurted in 1850 , city ordinance violations fell back. ${ }^{865}$

From this, we can conclude that the substance of the ordinance in question, like that of "offenses against religion," concerned liquor sales. Without more, we cannot be sure of the ordinance's penalty scheme, and we cannot know whether it was suited to prosecutorial charge bargaining. It is fair to

860. FERDINAND, supra note 121 , at 59 tbl.2.3.

861. Id. at 75 tbl.3.3.

862. See Act of Mar. 24, 1832, ch. 166, \$ 5, 1832 Mass. Acts 474, 474-75; see also Act of Apr. 20,1837 , ch. $242, \S 1,1837$ Mass. Acts 279,279 (raising the statutory penalty for Sunday sales to $\$ 20$ per offense).

863. See supra notes $36-44$ and accompanying text.

864. See, e.g., Commonwealth v. Thomas Barber, Middlesex Ct. C.P. R. Book 158 (Oct. 1842) (copy on file with the author) (charging four Sunday sales); Commonwealth v. Thomas Barber, Middlesex Ct. C.P. File Papers (Oct. 1842) (copy on file with the author) (containing the preprinted indictment form for the previous case).

865. FERDINAND, supra note 121, at 150. 
guess that this city ordinance was punishable by a fine only, though whether it attached a fixed fine to each offense I cannot say.

"Vice offenses," Ferdinand tells us, "include gambling and prostitution." $866 \mathrm{He}$ does not itemize the offenses that fall under "gambling," and there are several possibilities. First are the "gaming" offenses addressed by section 11 of the 1832 liquor-license law. The law punished those who permitted "dice, cards, bowls, billiards, quoits," or other games on their premises with a ten-dollar fine for each offense and punished those who took part with a ten-dollar fine. ${ }^{867}$ Like the rest of the liquor-license law, this provision gave the prosecutor the power to manipulate the sentence by manipulating charges. A different gaming provision also provided for a fixed ten-dollar fine. ${ }^{868}$ Other statutes bearing on offenses that could be labeled gambling, however, supplied no fixed penalty ${ }^{869}$ Without a finer breakdown of Ferdinand's "gambling" category, it is hard to know whether his findings support or challenge my arguments.

The second of Ferdinand's vice offenses, prostitution, clearly does not fall within my charge-bargaining paradigm. Ferdinand does not specify the statute governing the offense in question, but there seem to be only two possibilities: Being a "common night walker[]" made one liable to confinement for up to six months, ${ }^{870}$ and "keep[ing] a house of ill fame" carried a penalty of up to two years or $\$ 300 .{ }^{871}$ These wide-open penalty schemes did not permit the kind of charge bargaining I have discussed, and yet Ferdinand reports some facts suggesting a high incidence of plea bargaining in these cases. ${ }^{872}$ On the other hand, Ferdinand reports that the overall rate of guilty pleas in prostitution cases was slightly less than that for the average common-law crime. ${ }^{873}$

As prostitution apparently was not prosecuted in the middle-tier courts of Middlesex County, I cannot apply my own data to the task of explaining Ferdinand's findings. Of course, a guilty plea by a friendless prostitute

866. Id. at 59 tbl.2.3.

867. $\S 11,1832$ Mass. Acts at 478; see also Act of Feb. 28. 1787, ch. 68, 1786 Muss. Acts 210,210 (providing in an earlier version of the same act for a fine of 40 shillings for permitting gaming and a fine of 20 shillings for taking par).

868. See MASS. REV. STAT. ch. 50, $\$ 18$ (Dutton \& Wentworth 1836) (punishing playing at billiards).

869. See id. $\S 17$ (punishing persons not licensed as innholders with fines of up to $\$ 100$ for keeping gaming apparatus and related offenses); id. ch. 132, $\S \S 1-2,4-5$ (punishing various "lottery" offenses with fines of up to $\$ 2000$ or prison terms of up to three years).

870. Id. ch. $143, \S \S 5,6$.

871. Id. ch. $130, \S 8$.

872. See FERDINAND, supra note 121, at 75 tbl.3.3, 77, 81.94 (finding it significant that the practice of switching an initial not-guilty plea to a guilty plea developed carlier in prostitution cases than in others); id. at 75 tbl.3.3 (showing a striking drop in the rate of not-guilty pleas in prostitution cases in the mid- and late 1840s); id. at 78 tbl.3.5 (showing that those prostitution defendants who pled guilty got shorer prison terms than those who went to trial and lost).

873. See id. at 50 tbl.2.2. He reports "little evidence" of plea bargaining among common-law crimes. Id. at 92. 
might have been as much the product of hopelessness as negotiationsomething I suggested earlier with regard to drunkenness prosecutions. ${ }^{874}$ And a judge's compassion for an accused prostitute who showed remorse by pleading guilty also need not have been the result of bargaining. Moreover, I cannot tell whether Ferdinand's findings in prostitution cases represent on-file plea bargaining of the sort I discussed in Part III. Ferdinand does distinguish cases left on file from those ending in guilty pleas, ${ }^{875}$ but he does not tell us how he counts those cases that were placed on file after a guilty plea-the mark of an on-file plea bargain. ${ }^{876}$ On-file plea bargaining was, as I argue, simply probation by another name, and John Augustus, Boston's probation pioneer, devoted much of his labor in the latter part of the 1840 s to prostitution defendants. ${ }^{877}$ As Ferdinand reports a near-tripling in the percentage of prostitution cases left on file in the $1840 \mathrm{~s},{ }^{878}$ there is a real possibility that he is seeing on-file plea bargaining and simply failing to distinguish it from other forms. So again, without more detail, it is impossible to say whether Ferdinand's findings support or challenge my own.

874. See supra note 236.

875. See FERDINAND, supra note 121 , at 59 tbl.2.3.

876. See supra notes 298-299, 357-360 and accompanying text.

877. See AUGUSTUS, supra note 387, at 33-37; see also id. at 78-79 (reprinting an 1848 newspaper item accusing Augustus of keeping "a sort of Magdalen Asylum").

878. See FERDINAND, supra note 121 , at 74 tbl.3.2. 